4 is:

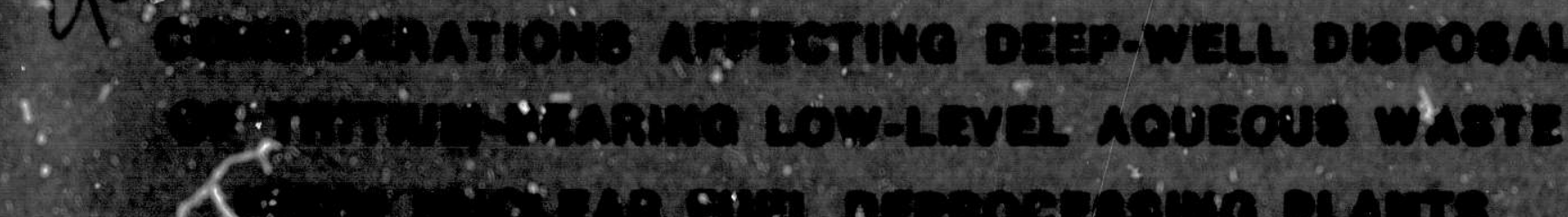
$10.0 \%$

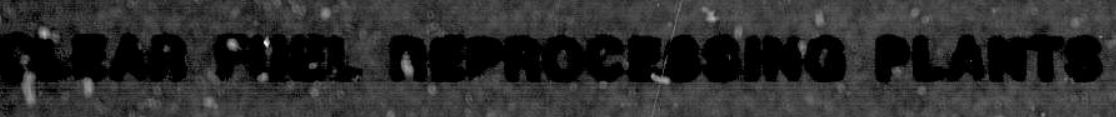

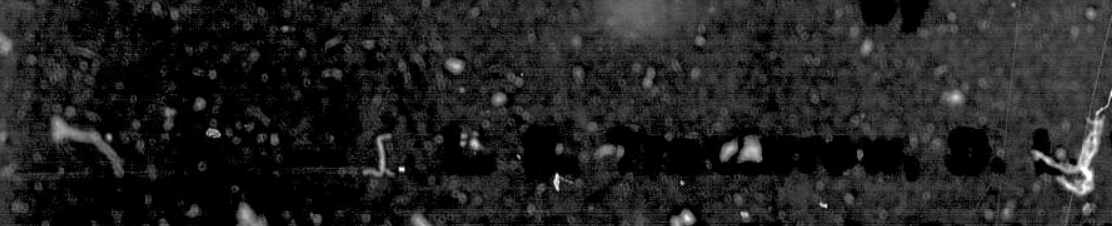

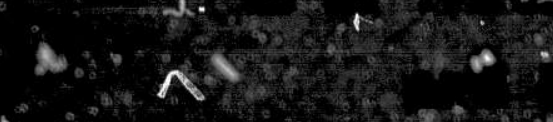

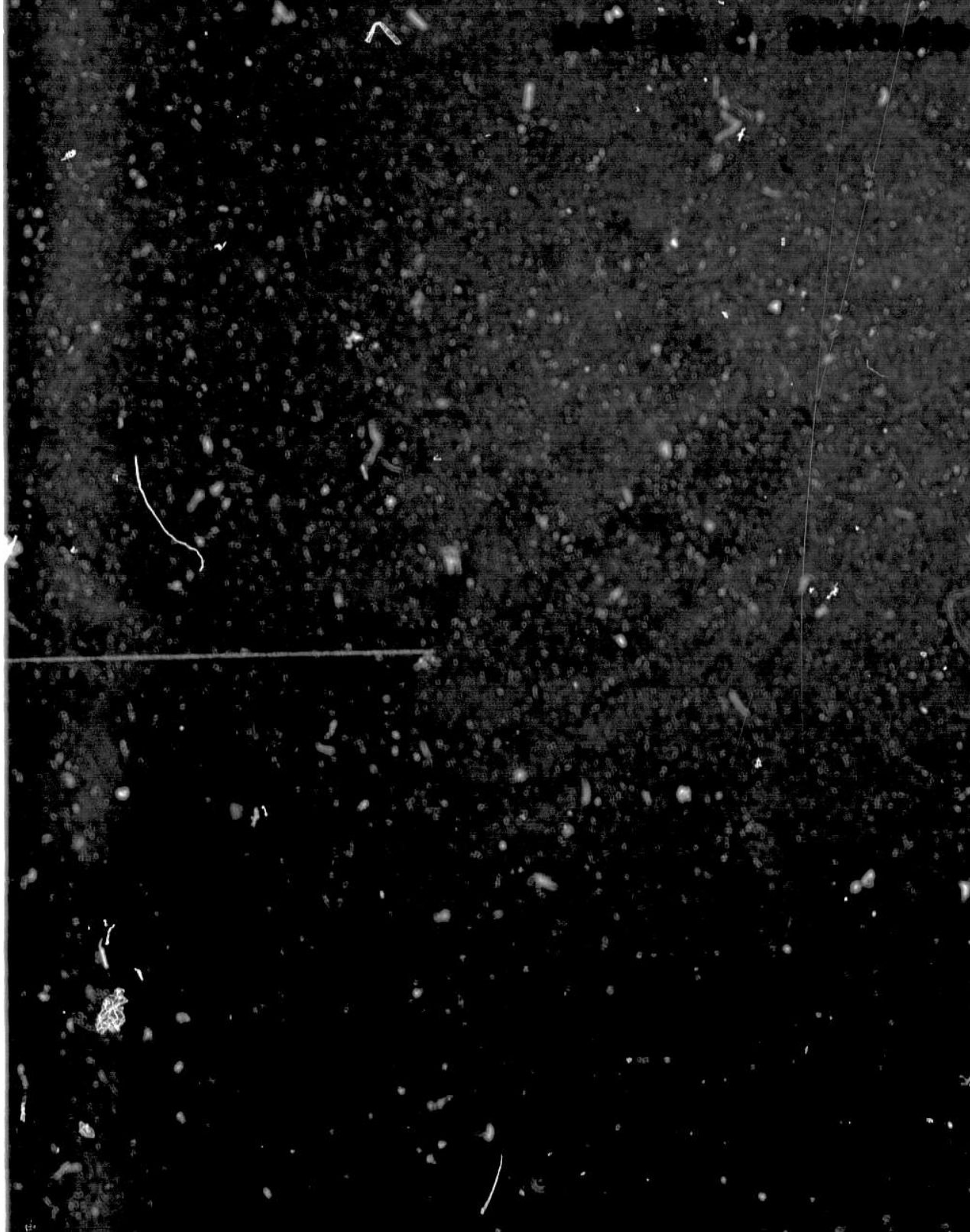
1.

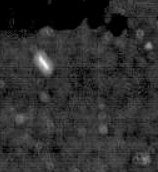

8 

Distribution Category:

Nuc lear Waste Management $(\mathrm{UC}-70)$

ANL- 76-76

\begin{abstract}
ARGONNE NATIONAL LABORATORY
9700 Soith Cass Avenue

Argonne. I111nols 60439
\end{abstract}

CONSIDERATIONS AFFECTING DEEP-WELL DISPOSAL

OF TRITIUM-BEARING LOW-LEVEL AQUEOUS HASTE

FROM NUCLEAR FUEL REPROCESSINC PLANIS

by

L. E. Trevorrow, D. L. Warner, *

and $M . J$. Steindler

Chealcal EngineerIng Division

March 1977

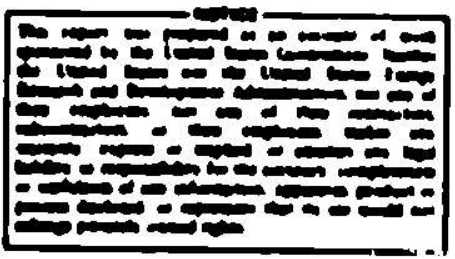



TABIE OF CONIENIS

Page

ABSTRACT. . . . . . . . . . . . . . . . . . . . . . . . . . . 1

I. INTRODUCTION. . . . . . . . . . . . . . . . . . . . . . . . 1

A. Objective and Scope of this Work. . . . . . . . . . . . . I

B. Origin of Aqueuus Trit lum Hasce In the LWR Fucl cy:Le and Opt lons for Its Dispusal . . . . . . . . . . . . . . . 2

C. Previous Consideration of Deep-Well Injection wi HighLevel Waste. . . . . . . . . . . . . . . . . . . . . . . 4

D. Previous Consideration of Deep-Well Injection uf Low-Level Haste. . . . . . . . . . . . . . . . . . . 5

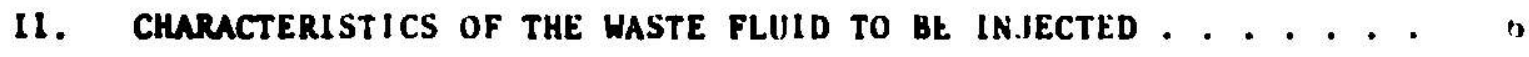

A. Ceneral Importance of Haste-Fiuld Characteristics. . . . t

B. Sources of Inforation on Low-l.evel Aqueous Waste

Compusition. . . . . . . . . . . . . . . . . . . 6

1. Exper1ence. . . . . . . . . . . . . . . . . . H

2. Differences Betwen Past Experlence and Future Comerclal Experlence . . . . . . . . . . . . . . H

3. Predictions of l.LAW Compositlon . . . . . . . . . . . 9

C. Volune . . . . . . . . . . . . . . . . . . . . . 12

D. Phyelcal Characteriselcy . . . . . . . . . . . . . . . 14

1. Denelty . . . . . . . . . . . . . . . . . 14

2. Viecoslty . . . . . . . . . . . . . . . . 14

3. Temperature . . . . . . . . . . . . . . . . 15

4. Suepended Sollda Content. . . . . . . . . . . . Is

5. Cas Content . . . . . . . . . . . . . . . 15

E. Cheoical Characterietlce of Heatewater. . . . . . . . . Is

1. pH. . . . . . . . . . . . . . . . . . . . 15

2. Chemlcal Steblltty. . . . . . . . . . . . . . . 16

3. Cheetial Reactlvicy. . . . . . . . . . . . . . 16

F. Toxletty . . . . . . . . . . . . . . . . . . . 19

1. Chontcel . . . . . . . . . . . . . . . 19

2. Indlonctivity . . . . . . . . . . . . . . . . 20

6. Sumery. . . . . . . . . . . . . . . . . . . . . 20

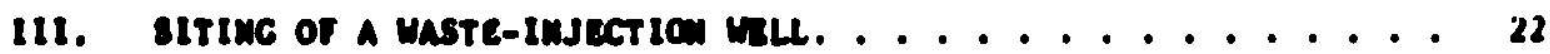

A. Coneral Consteretsone . . . . . . . . . . . . . . 22 
B. Factors ir Site Evaluation . . . . . . . . . . . 25

1. Stratigraphic Geology . . . . . . . . . . 25

2. Structural Geology. . . . . . . . . . . . 27

3. Lithology . . . . . . . . . . . . . 33

4. Subsurface Water. . . . . . . . . . . . 33

5. Mechanical Properties of Infection and Confining

6. Hydrodynamics ................. 46

7. Subsurface Resources. ............. 47

c. Acquisition of Subsurface Data . . . . . . . . . 48

1. Prior to Drilling ............... 48

2. During Well Construction and Testing. . . . . . . . 48

D. Prediction of Aquifer Response . . . . . . . . . . . 53

1. Reglonal Flow............... 53

2. Pressure Effects of Injection ........... 56

3. Rate and Direction of Fluid Movement. . . . . . 58

4. Hydraulic Fracturing. . . . . . . . . . . 59

5. Generation of Earthquakes ............ 62

E. Chararterisilcs of Sedimentary Basins in the United

States . . . . . . . . . . . . . . . 63 63

IV. DESIGN, CONSTRUCTION, AND OPERATION OF INJECTION SYSTEM . . . 66

A. Surface Equipment. . . . . . . . . . . . . . 67

B. Well Design and Construction ............. 70

1. Botton-Hole Completion. . . . . . . . . . . 71

2. Selection of Casing and Tubing. ......... 74

3. Cement. . . . . . . . . . . . . 77

4. Well-head Controls.............. 77

C. Syster operation ................ 77

D. Monitoring . . . . . . . . . . . . . . 81

1. Monitoring at the Injection Well. .......... 81

2. Monftor Welle (Separate fron the Injection Well). . 82

3. Other Monitoring Poseltilities. . . . . . . . 85

V. LEGN ND REGULATCRY CONTROLS . . . . . . . . . . . . 86

A. Inportance and Present State of Applicable Lawe and

Regulations. . . . . . . . . . . . ... 86 
B. Agenctes Likely to Regulate Injection of LLAW. . . . . . 86

C. The Federal Process for Licensirig Nuclear Facilitles . . 88

1. Assumptions and Considerations Related to Licensing an Injection Well . . . . . . . . . . . . 88

2. Informal site Review. . . . . . . . . . . . 88

3. Application for and Prelimtnary Review of a Construction Permit.............. 88

4. Technical Review by Regulatory Staff. . . . . . . 89

5. Public Hearing on Construction Permit . . . . . . . 89

6. Review of Application for Operating License . . . . 90

7. The Federal Inspection Program. . . . . . . . . 90

D. The Role of State Agencies in Deep-Well Injection of Waste. . . . . . . . . . . . . . . . . 91

1. Laws. . . . . . . . . . . . . . . . 94

2. Regulat 1ons................. 95

3. Pollcy. . . . . . . . . . . . . . . 95

E. The Possible Role of EPA In Regulation of a Proposed Injection of LlAW. . . . . . . . . . . . . . 95

F. The Possible Role of USGS in Licensing and Regulating a Proposed Injection of LLAW . . . . . . . . . . . . 96

G. Common Law Constraints . . . . . . . . . . . . 96

1. Subsurface Ownershlp. . . . . . . . . . . 97

2. Llabillty ................ 97

VI. ENVIROMENTAL IMPACT. . . . . . . . . . . . . . 98

A. Required Environmental Review Procedures . . . . . . . . 98

B. General Observations on Environmental Impact of Deep-Well Waste Injection. . . . . . . . . . . . . . 99

C. Possible Environmental Effects of Specific Contaminants. . 101

VII. WELL DECOMISSIONING. . . . . . . . . . . . . 104

vill. costs ......................... 105

A. Review of Othar Cost Studies and Selection of Cost Methode to be Used in Th1s Work. . . . . . . . . . . . . . 105

B. Capltal Costs. . . . . . . . . . . . . . . 105

1. Expected Proportion of Capital Cost to Total Cost . . 105

2. Mell Conetruct ion Coste............. 106

3. Injection Puquing Equipeant ........... 109 
4. Waste Pretreatment Facllities. . . . . . . . . 110

C. Operating Costs . . . . . . . . . . . . . . 110

1. Power Costs. . . . . . . . . . . . . . . 110

2. Chemicals for Wastewater Treatment . . . . . . . 111

3. Other Operating Costs. . . . . . . . . . . . 111

IX. EXAMPleS . . . . . . . . . . . . . . . . . 115

A. Anaconda Company Infection Well . . . . . . . . . 115

1. General Dlscussion ............... 115

2. Site Geology .. . . . . . . . . . . . . . 117

3. Wastewater Character . . . . . . . . . . . . 118

4. Well Construction and Test1ng. . . . . . . . . . 120

5. Surface Facllities................ 123

6. Monttoring ................. 124

7. Regulation . . . . . . . . . . . . . 124

8. Costs. . . . . . . . . . . . . . 125

B. Kerr-Mcfee Corporation (Sequoyah) Urantum Hexafluoride

Production Plant. . . . . . . . . . . . . . . 125

1. General Discussion . . . . . . . . . . . . 125

2. Site Geology ... . . . . . . . . . . . . 127

3. Wastewater evaluation. . . . . . . . . . . . 129

4. Well Construction and Testing. . . . . . . . . 129

5. Surface Pacilitles ................ 133

6. Mon1toring .................... 133

7. Regulation ................. 133

C. Nuclear Puel Services, Weat Valley, Nav York. . . . . . . 134

1. General Dlscussion .............. 134

2. S1te Ceology . . . . . . . . . . . . . . 134

3. Design and Speciflcations of the Propoend Dioposal Well at the Nuclear Puel Services Plant......... 136

D. Idaho Chealcal Proceselng Plant . . . . . . . . . . 139

1. Coneral. . . . . . . . . . . . . . . 139

2. Site Hydrology and Goology ............. 140

3. Hastwater ................. 141

4. Wall Faclidtlas. . . . . . . . . . . . 142

5. Monttoting .................... 142 
6. Regilations. . . . . . . . . . . . . . . 144

7. Distribution of Wastes in the Aquifer. . . . . . . . 144

E. Allied-Gulf Nuclear Services, Barnwell Nuclear Fuel Plant, Barnwell, South Carolina................. 144

F. General Electric Fuel Reprocessing Plant, Morris, Illinols. . . . . . . . . . . . . . . 145

1. General Discussion ........... 145

2. General Geology. ................ 145

X. CONCLUSions. . . . . . . . . . . . . . . . . 146

A. Technology. . . . . . . . . . . . . . . . 146

B. Economics . . . . . . . . . . . . . . 146

C. Environinental Impact. . . . . . . . . . . . . . 147

D. siting. . . . . . . . . . . . . . . . . 147

E. Legal and Regulatory Constraints. . . . . . . . . 148

APPENDIX A. . . . . . . .............. 150

Methoda Other than Deep-Well Injection for Geological Emplacement

of Fuel-Reprocessing Wastes. . . . . . . . . . . . . 150

1. Storage of Liquid HAH in Savannah River Bedrock . . . . . 150

2. Hydraulic Practuring. . . . . . . . . . . . . 150

3. Llquid Diaposal Through Cribs .............. 151

4. Incorporation of Nuclear Waste in Deep Molten S1licate Rock. . . . . . . . . . . . . . . 15!

APPENDIX B. . . . . . . . . . . . . . . . . . 154

Equivalency of Permeability Values In Varlous Units. . . . . 154

APPENDIX C. ....................... 155

Example of a Coaprehensive Set of State Regulations by the Colorado Dept. of Health, Hater Pollution Control Comission . . 155

APPENDIX D. . . . . . . . . . . . . . . 165

Pollcy Statesent on the Underground Infection of Westewaters Adopted by the Oh1o RIver Velley Sanitation Comiseion . . . . 165

APPENDIX E. ........................ 167

Adeinietrator'. Decielon Statesent 15. .......... 167

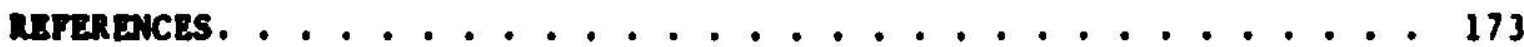




\section{LIST OF FIGURES}

No.

Title

$\underline{\text { Page }}$

1. Abbreviated Diagram of General Purex Scheme, with Emphasis on the Origin of Low-Level Aqueous Waste and the Major Pathweys of Ionlc Fission Products and $\operatorname{Tr} 1$ tium . . . . . . . . . . . . . . . 3

2. Schematic Illustration of Deep-Well Infection of Waste...... 5

3. Abbreviated Purex Flow Sheet; Basis for Estimating Concentrations In Low-Level Waste of Normal Operation from Reference Concentrations In High-Level Waste.................. 10

4. Abbreviated Purex Flow Sheet; Basis for Estimating Concentrations In a Process-Upset Waste from Reference Concentrations in HighLevel Waste. . . . . . . . . . . . . . . . . . . . . . 11

5. Example of Generalized Columnar Section: Cambrlan and Ordovician Strata in Northeastern Illinois. . . . . . . . . . . . . 26

6. Example of Isopachous Map: Thickness in Ft of the Ht. Simon Formatiun in Illinols...................... 28

7. Example of Stratigraphic Map . . . . . . . . . . . . 29

8. Exampie of Lithologic Ratio Map: Post-Mt. Simon Pre-Knox Rocks. . 30

9. Map of the Ohlo River Basin and Vicinity Showing Some Major Geologic

Features. Data Modiffed from Published Maps . . . . . . . . 31

10. Example of Structural Contour Maps; Top of the Mt. Simon

Formation. . . . . . . . . . . . . . . . . . 32

11. Example of Map Indicating Depth to Aquifers Containing Dissolved Sol1ds Concentration $<1,000 \mathrm{mg} / 1 . . . . . . . . . .35$

12. Example of Isocon Map, Showing the Dissolved Solids Content in Parts per Million of Hater in the Upper 100 Feet of the Mt. Simon Formation In Illinols..................... 37

13. Viacosity of Subsurface Water as a Punction of Reservoir Temperature and Total Dlssolved Sollds Content............... 39

14. Relation Between Relacive Denelty and Dissolved-Solids Content of Brines in Deep Aquifere of the Illinols Basin. . . . . . . . . .

15. Variation In the Compraselb111ty of Water with Teaperature and Preseure . . . . . . . . . . . . . . . . . . . .

16. Exaple of Potosity Distribution: Average Porosity of the Mt. Sinon Formetion In Illinols. . . . . . . . . . . . . . . 
17. Examplo ot Mapping of Geothermal Gradients Adopted from Portfolio Map No. 10, from the American Association of Petroleum Ceologists Geothermal Survey of North Amerlca . . . . . . . . . . .

18. Fxample if Map lllustrat fng Potentials for Flow of Subsurface Flulds. Potentiometric Surface Map for the Mt. Simon Formation In ohlo and ladlans. . . . . . . . . . . . . . . .

19. Plot of Recove. I Ind Matching-Type-Curves for an Injection

Well at Mulber '. '. rida. . . . . . . . . . . . . . .

20. Hydrogeology of tlie Lower Floridan Aquifer in Northwest Florida, Indicat ing the Altitudes of Potentlometric Surfaces Prior to Injection.

21. Hydrogeology of the lower Floridan Aquifer in Northwest Florida, Indicating the Altitudes of Potent lometric Surfaces After WasteWater infection had been in Progress for 8 Years ........ 57

22. Pressure-Time Relation During Hydraulic Fracturing . . . . . . 61

23. Geologic Features Significant in Waste-Injection Well-Site Evaluation and Locations of Some Industrial Wastewater Injection Systems. . . . . . . . . . . . . . . . . . . . . .

24. Schemist Ic Example of Pre-Injection Waste Treatment Facilities for an Acid Industrial Wastewater. . . . . . . . . . . . . .

25. Methods of Well Completion . . . . . . . . . . . .

26. Schemat1c Diagram of an Industrial Waste Injection Well completed in Competent Sandstone ...................

27. Schemat Ic Drawing of the Well-Head Assembly for a Typical

Injection Well ......................

28. Preinjection and Postinjection Caliper Logs from a Wastewater Injection Well at Belle Glade Florida, Showing Solution of the Limestone Aquifer in the 1500-1600 Foot Interval by Acidic Wastewater. . . . . . . . . . . . . . . . . . . . 79

29. Schematic Dlagram of a Cement Bond Logging Tool in a Borehole. . . 80

30. Average Conatruction Cost of 011 and Gas Wells in the United States in 1973. Prepared frow Data in the Jolnt Association Survey of Drilling Costs.......................

31. Sketch Map Showing the Locating of the Anaconda Company's Disposal Well . . . . . . . . . . . . . . . . . . . . .

32. Schematic Sketch of Well Proposed for Waste Iujection at Kerr-

McGee Sequoyah Fac1lity. . . . . . . . . . . . . . . 131 
33. Dlagrammatic Cross Section Along the 42nd Parallel, Western New York . . . . . . . . . . . . . . . . . . 135

34. Sketch of Disposal Well Proposed for the Nuclear Fuel Services Plant. . . . . . . . . . . . . . . . . . . 137

35. Geolog1c Cross Section Througn the ICPP Area Showing Generalized Stratigraphy, Perched Water, Wells, and Reglonal Water Table . . 141

A-1. Cross-Section of Proposed Savannah River Plant Bedrock Waste Storage Facillty. . . . . . . . . . . . . . . . . 150

A-2. Diagram of the Concept of Waste Disposal by Hydraulic Fracturing as Tested at the oRn site................. 151

A-3a. Crib-and-Tile F1eld Before Backf111. . . . . . . . . . . 152

A-3b. Movement of Specific Ions from Criba . . . . . . . . . . 152

A-4. Composite Illustration of the Concept of Disposal of Nuclear Waste into Deep Molten Silicate Rock . . . . . . . . . . . . 153 


\section{LIST OF TABLES}

№.

Title

Page

1. Factors to be Considered in Evaluating the Sultability of Untreated Wastes for Deep-We11 Disposal. . . . . . . . . . . 7

2. Est 1mated Concentrations of Dissolved Solids in Low-Level Liquid Waste. . . . . . . . . . . . . . . . 13

3. Coinparison of Concentrations of Radioactive Isotopes in LLAW with Radiation Concentration Guldelines . . . . . . . . . . . . . 21

4. Factors to be Considered for Geologic and Hydrologic Evaluation of a Site for Subsurface Waste Infection. . . . . . . . . . . . . .

5. Example of Core Description (Taken from the Top of the Mt. Simon Formation from a Well in Illinots)............. 34

6. Example of Composition of Native Aquifer Fluids; Analysis of Water from the Mt. Simon Formation in the Vicinity of Bloomington, Illinols..................... 38

7. Well Logging Methods and Their Applications. . . . . . . . . 50

8. Calculated Distance of Wastewater Travel for 148 Injection Wel\}s Af ter 10 and 50 Years of Operation, Using Equations 4-9 and 4-10 . 60

9. I'ndesirable Characteristics of Wastewaters for Injection Purposes and Means of Control . . . . . . . . . . . . . . . 68

10. Determination of Recommended Bit Stzes for API Casing. . . . . . 76

11. Common B1t Sizes...................... I6

12. Monitor Wells--Types and objectives. . . . . . . . . . 83

13. Present Attitudes of State Governments Toward Deep-Well Injection of Wastes in General, Indlcated by Recorded Pollcy, Laws, and Types of Regulation. . . . . . . . . . . . . . . 93

14. Estimate of Maximum Number of Persons that Could be Exposed to Water Containing the Maximum Permiasible Concentration of Contam1nant by Hypothetical Leakage of LLAW Srom Injection Well of 5 MTU/day Fuel-Reprocessing Plant into Public Water Supply . . . . . 102

15. Estimated Effects Incurred through Continuous Drinking of Water Contaminated by Leakage of LLAW from Waste Well of a $5 \mathrm{MTU} / \mathrm{day}$ Fuel-Reproceasing Plant Into Public Water Supply . . . . . . . 103

16. Engineering News Record Bullding Cost Index. . . . . . . . . 108

17. Estimsted Costs for Two Examples of Deep-Well Injection of LLAW. . 113 
18. Plant Lifetime Costs of Deep Well Injection of LIAW for Two

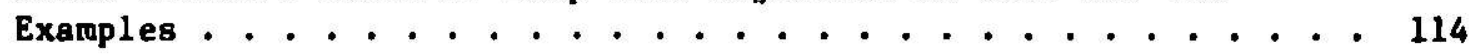

19. Summary of Undt Costs for Deep Well Infection of LLAW. . . . . . 116

20. Chemical Analysis of Formation Water, Infection Water, and

Returned Injection Water from The Anaconda Company Well, Grants.

New Mexico . . . . . . . . . . . . . . . . . . . 119

21. Costs of Construction and Testing of The Anaconda Cerpany Disposal

Well System. . . . . . . . . . . . . . . . . . . . 126

22. Rock Sequence at the Site of the Waste Disposal Well Constructed at the Kerr-McGee Company Urantum Hexafluorlde Production Plant. . 128

23. Composition of Wastes Proposed for Deep-Well Disposal at the KerrMcGee Co. Urantum Hexafluoride Production Plant. . . . . . . . 130

24. Schedule for Casing and Cementing the Waste Disposal at the KerrMcGee Uranium Hexafluoride Production Pac1l1ty . . . . . . . . 132

25. Maximum Permissible Concentrations of Radiolsotopes in Drinking Water Compared to Average Concentrations In ICPP Disposal Well

Effluent .................... . . 143 


\title{
CONSIDERATIONS AFFECTING DFEP-WELL DISPOSAL OF TRITIUM-BEARING LOW-LEVEL AQUEOUS WASTE FROM NUCLEAR FUEL REPROCESSING PLANTS
}

by

L. E. Trevorrow, D. L. Warner, and M. J. Steindler

\begin{abstract}
Present concepts of disposal of low-level aqueous wastes (LLAW) that contain much of the fission-product tritium from light water reactors, involve dispersal to the atmosphere or to surface streams at fuel reprocessing plants. These concepts have been challenged in recent years. Deep-well injection of low-level aqueous wastes, an alternative to blospheric dispersal, is the subject of this presentation. Many factory must be considered in assessing its feasibllity, Including technology, costs, environmental 1mpact, legal and regulatory constraints, and siting. Examination of these factors indicates that the technology of deep-well injection, extensively developed for other industrial wastes, would require little innovation before application to lowlevel aqueous wastes. Costs would be low, of the order of magnitude of $10^{-4}$ $\mathrm{mill} / \mathrm{kWh}$. The environmental impact of normal deep-well disposal wuld be small, compared with dispersal to the atmosphere or to surface streans; abnormal operation would not be expected to produce catastrophic results. Geologically suitable sites are abundant in the U.S., but a well would best be colocated with the fuel-reprosessing plant where the LLAW 1s produced. Legal and regulatory constraints now being developed will be the most Important determinants of the feasibility of applying the method.
\end{abstract}

\section{INTRODUCTION}

\section{A. Objective and Scope of this Work}

The objective of this report is to discuss the factors that must be considered in decisions on the application of deep-well disposal to low-level aqueous wastes from comercial reprocessing of LWR fuels. This report does not address specifically the feasibility of application at the two U.S. commerclal facllities, the Barnweli Nuclear Fuels Plant ${ }^{*}$ and the Nuclear Fuel Services Plant**, although conments that apply to these specific facilities are included. Th1s report 18 designed as a general reference of value to reprocessing, licensing, or regulatory activities, as they involve reviewing the feasibility of this technique in a specific case.

Th1s report was preceded by a brlef review (Trevorrow) ${ }^{\dagger}$ of the literature on deep-well injection of liquid wastes of general types. That review selected

\footnotetext{
Allled-General Nuclear Services, Barnwell, S.C.

** Nuclear Fuel Services, Inc., West Valley, N.Y.

tItems in parenthesis are references listed alphabetically in the final section of this report.
} 
topics that should be addressed in consldering the specific application of the method to LLAW. Topics that were concluded to be important were grouped Into five major categories: technology, costs, environmental impact, regulatory constraints, and siting. It is recognized that the method has a potential for general application in the nuclear fuel cyc?e. All of the various types of factlities of the $11 \mathrm{ght}$ water reactor fuel cycle produce low-level aqueous wastes (Licensing), including reactors and facllitles for uranium mining, uranium milling, $\mathrm{UF}_{6}$ production, fuel enrichment, fuel fabrication, and fuel reprocebsing. Since the characteristics of the wastes are pecullar to the type of facility, each case would require individual consideration. The present work was induced by concern for control of the tritium (formed mainly by flssion in 1 ight water reactor fuels), much of which 18 expected to appear in the low-1evel aqueous waste of plants in which LWR fuels are processed. Therefore, although application of the method to the milling facility of the Anaconda Company 18 discussed (section IX.A.), this work 1s addressed primarily to disposal of wastes generated at fuel-reprocessing faclittes. Another Indication of the potential for other application of deep-well injection to nuclear wastes problems, is the brief reference (Clebsch) to the possibllity that the f1ssion product wastes, krypton and lodine, could also be contalned in solution in the LLAW injected into deep wells.

\section{B. Origin of Aqueous Tritium Waste in the LWR Fuel Cycle and Optlons for Ite D18posel}

Disposal of the tritium formed by fission, in lighc water reactor fuels will be a problem at the plants where these fuels are reprocessed. The general scheme for commerclal fuel reprocessing that has been almost universally chosen (with varlous modifications) is the Purex flow sheet, in which tritiun will be released from the fuel in the dissolution step and is expected to be in the aqueous phase, eventually ac iumulating in the LLAH. Figure 1 is an abbreviated diagram of the general Purex schese, dram to emphasize the origin of low-level aqueous waste.

The LLAH is a dilute solution of nitric ac1d, with very low concentrations of dissolved solids. In the LLAH, the tritiun contribution to cotal radioactivity (In total Curies) is several orders of agnitude greater than any of the other radioactive constituents. The tritiu concentration is in excese of the radiation concentration guldeline for rolease to an uncontrolled area. Th1s constitutes the primary reasun for avolding direct exposure to LLAW. The half life for radloactive decay of tritlun is $12.3 \mathrm{yr}$; decay would reduce the tritiu concentration in LLAH to guldeline cincentrations in about $100 \mathrm{yr}$.

Storage of this waste in tanke, In order to peralt decay before release to the blosphere, Is generally considered to be uneconodic oulng to the relatively large volunes involved. The cotel volues of LLAW to be enaged during a fuel raprocessing venture can be predicted fron (1) lte seneration rate of about $10^{4} \mathrm{gal} / \mathrm{MrU}$. (2) the service 11 fetise of the reproceselng plant, and (3) the annual capacity (In MrU) of the reproceseling plant. Eet lates of the operating llfet ine of adel fuel reproceselng plant vary from 20 (LIcenaing) to $4 \mathrm{C}$ yr (USEPA 1973A). 


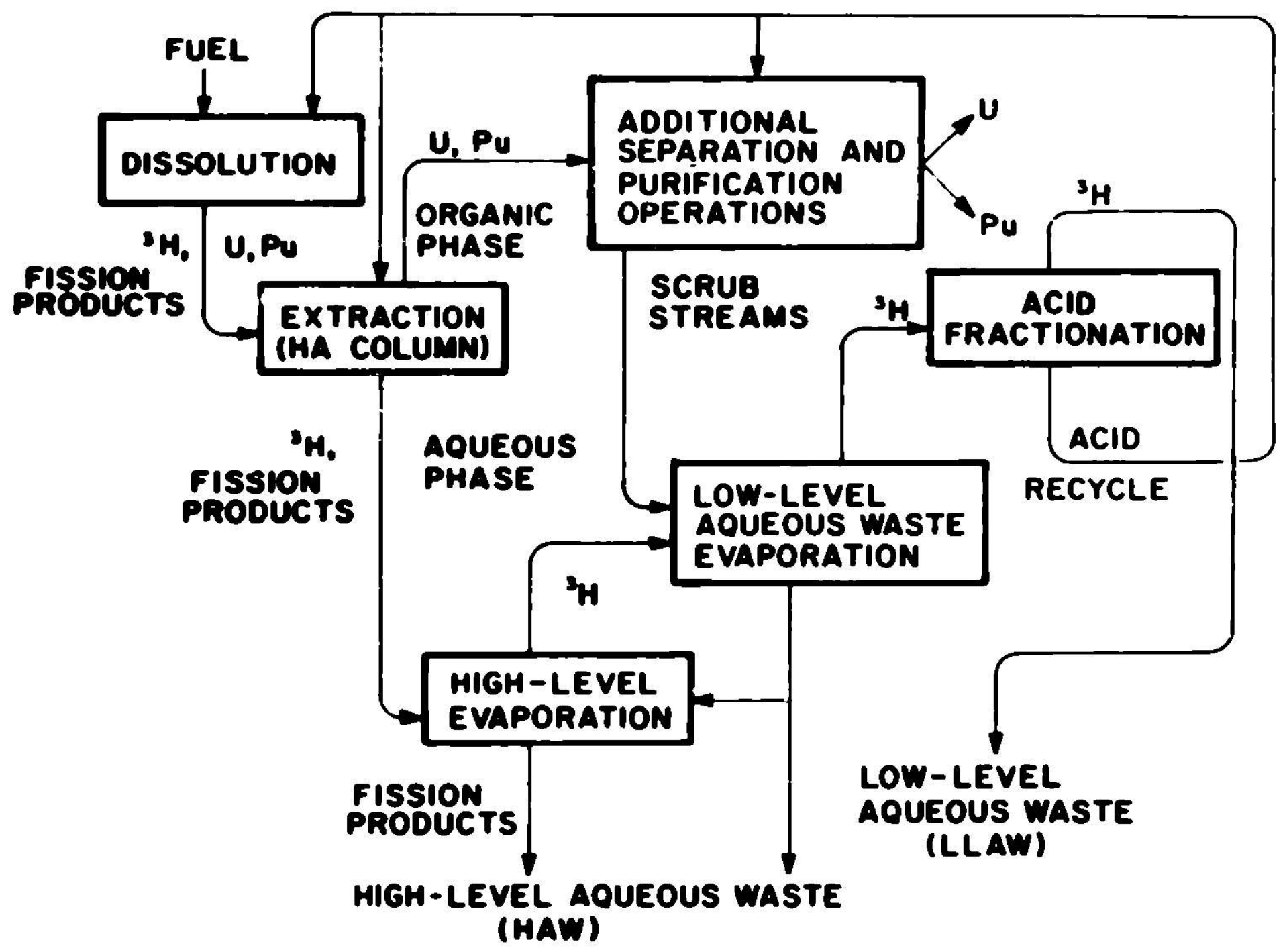

Fis. 1. Abbrewlated Diagre of General Purex Scheme. With Emphas is of. the Origin of Low-Level Aquerous Yastes and the Major Pattways of Ionic Flssion Products and Tritilum 
Plang for disposil of this wiste from comerelal reprocessing facllitles have included (1) dilut lon with water followed by disposal to surface streans (NFS) or (2) vaporlzat ion followed by dilution with alr and disposal to the atmusphere (BNFP). In the cllmate of critlism which has recently brought nuclear power and tts possible effects on the human population under scrutins, It was suggested that dlspersal of tritlum to the blospliere should be prohlbited. In anticlpation of $\mathrm{chls}$ posslbllity, a number of alcernative optluns for disposal of flasion-product tritlum have been considered (Burger. Lin, Bixel, Ellis, R(bnikar).

One critlum-disposal option Involves removing tritium from spent fucl before it is dissolved, thus avolding the creation of large volumes of tritiumcontaninated water. The trlelum-removal operation given the most attentiun 18 Voluxidat: $n$ (coode), whlch conslsts of a high-temperature oxidacton of fuel before dissolution. Thls oxidation converts the tritlum in the fuel to water which is vaporized from the fuel aacrix and condensed. The Intent is to lsolate the tri:lum in "volune of tritlated water sufflciently small for cconoalcally practicable storage. Evaluations have been made of the possibllltles of adding voloxidation to the BNFP (Yurbach) and to the NFS plant (Noreh).

Several of the proposed tritiuedisposal opt lons have Involved the separation of critio froe LLAW (i.e., in a hydrogen-lsotope separation procese) co effect a concentration and reduce the volume of waste to a range that could be etored econonically.

If boch speclal pre-dissolution head-end operatlons and concentration by leotope eeparation are excluded, deep-vell Inject Ion of LLAH 18 an option to be considered. The mothod consiste of punplng liquld vastes into the pores of a deep-lyilig (below (resh-vacer aquifer*), permeable. geologic stratua that Is bounded above and belou by confining etrata (aqulcludes or aquitards) that ere relatively Iepermable to water (Fig. 2). In order co further delinit the disposel wethod that ie under consideration in this report, a number of ocher mothode for geologic enplacesent of liquid wastes are briefly described In Appondix a to different late then from dec-mell Injection.

\section{Prevlour Conslderation of Deep-Hell Infection of High-Level Hase}

The Ides of dispose: of radloective vaste by injection, In liquid form, Into deep-lylse permable geologic formations la not recent (Straub). Liarly In the planning and diecuestons concerning the transfornation of flestion applicatione froe veapone to civilian pover, it becane apparent that dlsposal of fuel-reproceesing vacte vee a torenoet problen in the developeent of a complete nuclear Industry. Accordingly, beginning in about the alddle 1950e, weh etceation vas given to discuseton of the relative werite of a number of ldoese for diepoeal of high-lovel waste. One of the earliest recorded discusstione (MAS-miC 1957) of the poselbillty of deep-well injection occurted In 1953 in a contctee of geologlets and geophyelciste escablished by the Mational icedewy of sclencee-National Research Councll at the request of the

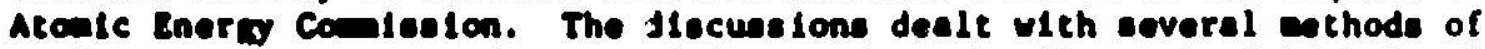
gaolosic eplacesont and wre eninly atend at the disposel of high-level waste, t.e. the botton etrece fron high-level wate evaporation whlch contalne relatively high concentrations of tonlc llesion producte and, therefore, high levele of redloectivity. The interest in pureulas thle anthod of dieposal 


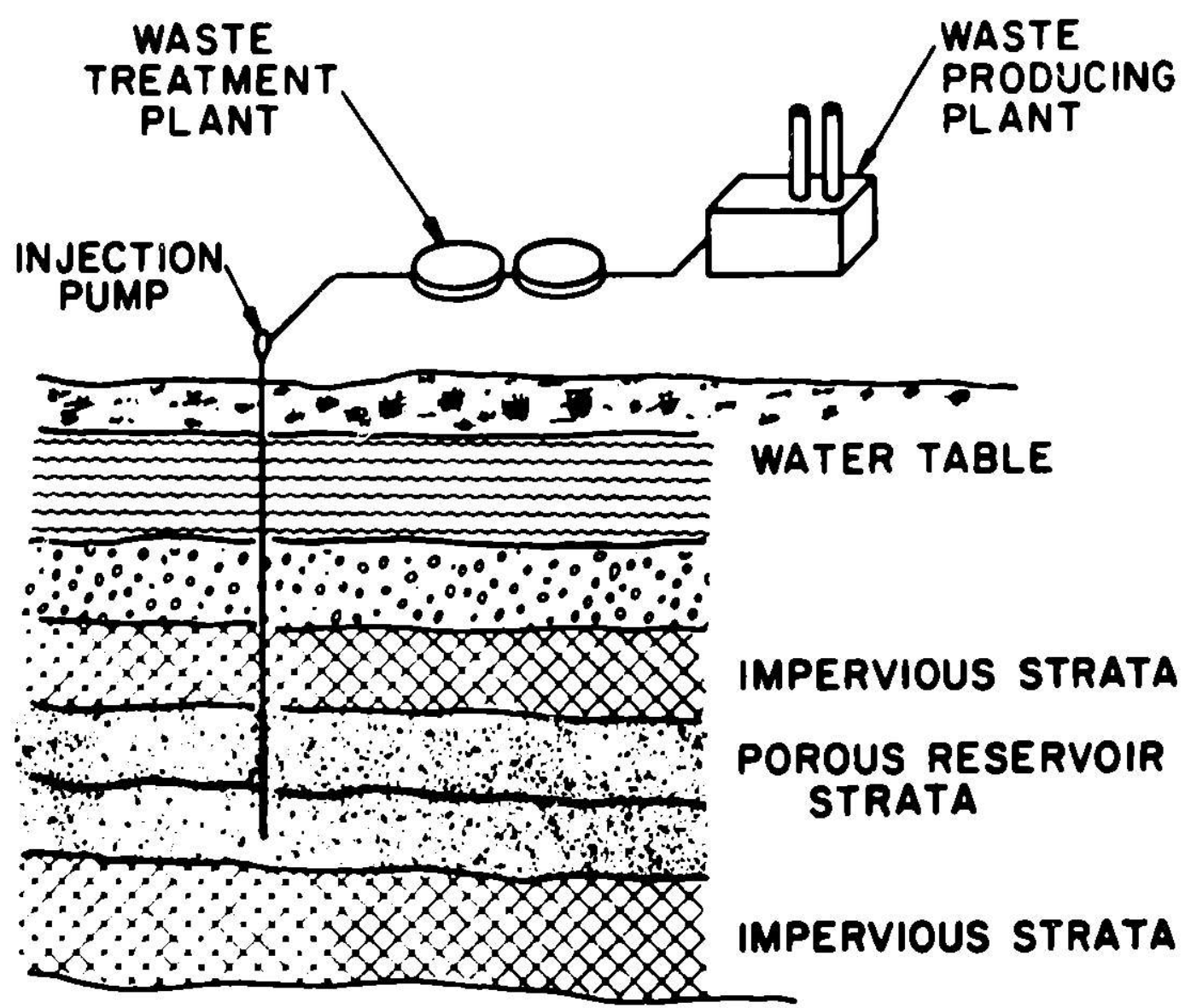

F1g. 2. Schematic Illustration of Deep-Well Injection of Haste (Otcinger)

proceeded into evaluations of U.S. geologic basins by the American Association of Petroleum Geologists (Galley) and by the U.S. Geological Survey (e.g., Love). The Interest in disposal of high-level waste by this means, however, has diminlahed, mainly becouse of a number of difficulties expected to fullow from the very high specific radloactivity of the liquid high-level waste, e.g., gas formation from radiolysis, the heat dissipation requirements, and the potential of a high erivironmental lopact in the evint of fallure after geologic emplacenint of the liquids.

The Investigations in the U.S. of the feasibility of disposal of HaW by deep-well injection have been oumarlzed (Clebech, Belter). Consideration of the safety, cconoaics, and sultablilty of avallable geologic basine in the deep-well injection of radioactive wastea has been briefly reviewed as a solution to French waste disposal probleas (Barbreau). Also, a number of descriptions of the application of thie method to internediate-level vustes In Russia continue to appear (Spltayn 1971, 1972; Kostin; Pimenov; Yudin).

D. Previnus Consideration of Deep-Well Iniection of Lon-Level Waste

The deep-well injection of LLAW can be practiced without disadvantagenul factore present In HAW, $i . e$. , the complications resulting from high theral 
power and high specific activity. Possible application to LLAW in the U.S. was suggested (Delaguna 1968A). Also, an application has been proposeo that especiaily emphisizes tritium control--infection of LLAW into the depleted oll horizons of the Leopoldshafen oil field In the Federal Republic of Germany (H1ld).

The only operation in the U.S. Involving disposal of LLAW from a fuelreprocessing plant into a well 18 at the Idaho Chemical Processing Plant. This operation differs from the typical industrial waste infection well in a number of ways which are listed in the more detalled discussion of this operation In Section IX.D. The Idaho Chemical Processing Plant discharges all lowlevel aqueoug waste to the Snake River Plain aquifer through a well. The depth of the well is about $600 \mathrm{ft}$. Its bottom $1 \mathrm{~s}$ about $150 \mathrm{ft}$ below the top of the aquifer, which. has a thickness of 1000 to $10,000 \mathrm{ft}$ and an effective porosity of 5 to $10 \%$. Estimates of the rate of lateral movement of water in the aquifer range from 5 to $20 \mathrm{ft}$ per day (Robertson 1974). The wastes are evaporator overheads which have recelvec an additional purification by 1 ion exchange so that the main radioactive ccoponent is tritium. The average annual rate of discharge to the well has been about $3 \times 10^{8} \mathrm{gal} / \mathrm{yr}$. The average tritium concentration in the waste was $430 \mathrm{pC1} / \mathrm{ml}$, and the estimated total tritium discharge since 1952 has been about $22,000 \mathrm{Cl}$. A model of the transport of waste in the aquifer was developed to permit calculations by digital computer (Robertson 1973).

\section{CHARACTERISTICS OF THE WASTE FLUID TO BE INJECTED}

\section{A. General Importance of Waste-Fluid Characterlstics}

The properties of the waste fluid to be infected are important determinants of the feasibility of applying this method of waste disposal. They indicate the extent and type of pre-1njection treatment that must be applied to the waste, or perhaps to the waste-recelving stratum, as well as the design, capacity, and materials requirements for equipment. This chapter presents a review of some general waste-fluld characteristics that are important and also a discussion of the properties of LLAW expected from comercial reprocessing of LWR fuels and their relation to the possible deep-well injection of LLAW.

Table 1 lists the characterlstics of an untreated wastewater that must be conoldered in evaluating ite sultability for disposal by subsurface injection. Prelieinary exanination of these factors will generally show whether or not an effluent is such that more detalled appraisal is varranted. A detailed etudy would attempt to def ine all of the design and operational problem related to the vastewater and to solve these probleme by waste pretreatent, design modification, and operational procedure.

In the resalnder of this chapter, the expected nature of the tritiubearing watewater w111 be defined and then related to underground injection.

\section{B. Sourcee of Information on Lar-Level Aqueoue Heste Corposte ion}

The inforantion needed for the present assesesent is the composition of low-level aqueoue waete to be expected in the comerciel reprocesaing of epent 
Table 1. Factors to be Considered in Evaluating the Sultabllity of Untreated Wastes for Deep-Well Disposal.

A. Volume

B. Physical Characteristics

1. Density

2. VIscosity

3. Temperature

4. Suspended sol1ds content

5. Gas content

c. Chemlcal Characteristics

1. Dissolved constituents

2. $\mathrm{pH}$

3. Chemical stability

4. Reactivity
a. With system componente
b. With geologic formation waters
c. With geologic formation ainerals

D. Biological Characteristica

1. Growth of alcroorgendene

2. Toxicity
a. Chenical
b. Rad loact Ive 
fuels fror. 11 ght water reactors involved in civilian power production. Since the commerctal nuclear fuel cycle has not yet been closed on a routine basis, information that is truly representative of experience is not avallable at this time. Information that is avallable is based elther on experienie that 1s not typical of the fuels and practices expected in the coming commercial fuel cycle, or on predictions. In view of the uncertainties in defining a reference composition for low-level aqueous waste representative of commerclal reprocessing, it is approprlate to describe in sume detall the informational sources on low-level waste and to discuss the basis for selecting those best used in arriving at the expected limits for the composition.

\section{Experience}

Processing experience at the Hanford and Suvannah River plants of the AEC has Included early flow sheets based on both precipitation an: solvent extraction processes, but the experlence relevant to the present problem is that obtalned in carrying out the Purex process, the basis for all presently planned comerclal reprocessing. Changes or replacement of some Putin operations In commercial adaptation have been investigated in the past, and some changes may be expected in the future, but the separation of urantum and plutuntum from the major portion (992) of the f1ssion products by a coextraction with tributyl phosphate (TBP), using $\mathrm{HNO}_{3}$ as salting agent, promises to be the basls for comercial practice involving LWR fuels in the near future. The Purex process was originally designed to recover both uranlum and plutonlum from Irradiated fuels (mainly metallic uranlum clad in aluminum). It has a long history of use, having first been put Into practice at the Savannah River Plant in 1954 and at the Hanford Plant in 1956 (Long). Since processing at these - tes has been 1 imited largely to plutonium product ion fuels, their vaste stream compositions differ significantly, with respect to both isotopic and chemical composition, frow waste streans from comercial processing of LWR fuels.

At the I daho Chesical Processing Plant (Stevenson) processing exper1ence has dealt with the recovery of uranlun from irradiated highly enriched fuele (about $90 x^{23} \mathrm{U}$ ), troe which the separation of plutonium is not generally worthohile. Thus the flow sheets for those operations differ fron conventional Purex flow sheets in not Including plutoniun recovery. Furthermore. fuels processed at the Idaho plant have usually cuntained alrconlun, elther in large mounte as a fuel alloy or In eacller asounts as a cladding materlal. Thus the flow sheets have Included organlc extractants other than, or in addition to, TBP. Also, in order to diseolve the zircontun, reagente not characteristic of the Purex process have heen used.

The only experience in coumerclal nuclear fwel raproceselng has conaleted of a fer campelgne se NPS. During operatione froe 1966 to 1972, when the plant closed for modification and expansion, a cotal of about 620 mTU hed been proceesed (HASH-1174-74). The fuel typee, and the flow eheets used In

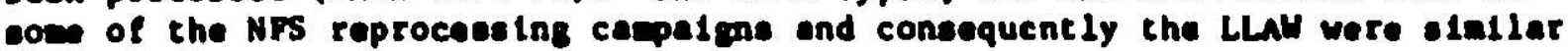
to those expected in future comercial practice.

2. Differences Between Past Experlence and Puture Co arclal Exper Ioncy 
past wll differ from future commerclal waste etreams are the efficlency of the evaporative uperations and the cumposition of feed to the evaporators. The feed to the low-level aqueous waste evaporator conslats of the overhead from the high-level evaporator and of scrub atreams from subsequent purification cycles (F1g. 1). The compusition of the leed to the evaporators depends on the fuel, the cladding, the flow sheet (whlch deterwines the reagents), and the materials of vessel construction (which determine the types and amounts of corrosion products in the feed to the evaporators).

In AEC plutonium-production processing, the aluminum cladding is dissolved, resulting in a high concentration of aluminum in feed to the HAW evaporator. In contrast, commerclal processing of LWR fuels (UO, clad in 71 rcaluv-.. or Zircaloy-4) will comence with chopping of the fuel pins and leaching of the exposed fuel away from the cladding. Thus, no dissolution of the cladding w11 occur in coumercial operations as in AEC reprosessing uperations, and less of the cladding constituents will be fed to the HAW evaporator. Improvements in evaporators are expected to produce higher DFs for volatile components and lower entralnment of nonvolatile constituents than was experienced in AEC reprocessing operations. Thus, the volatile and nonvolatile constituents of comercial LLAW will differ in degree and $k$ ind from those in LLAW from AEC plutonlum-production processing.

\section{Predictions of LLAW Composition}

From the above discussion, the characteristics of low-level aqueous waste to be expected from comercial reprocessing of civilian power reactor fuels are seen to be poorly defined. Interviews of representatives of the three U.S. comercial reprocessing facilities led to the conclusion that except for the secification of volume and radloactivity, characterlzacion (either by observation or prediction) of low-level aqueous waste has recelved litele attention by comercial fuel reprocessors. In the absence of other firm charecterizations at this tine, a reference definttion of low-level waste from fuel reprocessing has been restricted to information on its flow rate, pH, and concentration of dlssolved solids. The flow rates and pH are based on the vater balences and the flow sheete of the AONS and NFS plants. The concentrations of diesolved solids are taken to be equivalent to those produced by processing a reference high-level wate by dilution and then evaporative operstione in which aesumed decontanination factors are obtained. Eatimates of dissolved collde concentration heve been ande for a lover linit, based on three euccesslve evaporat lve operations on high-level waste, each with an assuned DF of $10^{3}$, and also for an uppar linit, based on an assuned "processupeet condition" In which only the HAH evaporator is operable and therefore the mixture of Inpute to the lou-level evaporator (the ecrub etrease and the overheade of the high-level evaporator) vould becone the waste requir ing dieposel. These condit lons are llluetrated by the abbrevlated diagrams of P18. 3 and FIg. 4. Pot nornel operation (P1g. 3), If DS is the quancity of diseolved collds In high-level waste concentrate and if $H_{H}$ and $L$ are the voluene of high-level vaste and low-level waste, reepectively, for noreal

\footnotetext{
Decontenination factor; DF - concentration of cuntasinant before operation/ concentration of contaminast after operation.
} 


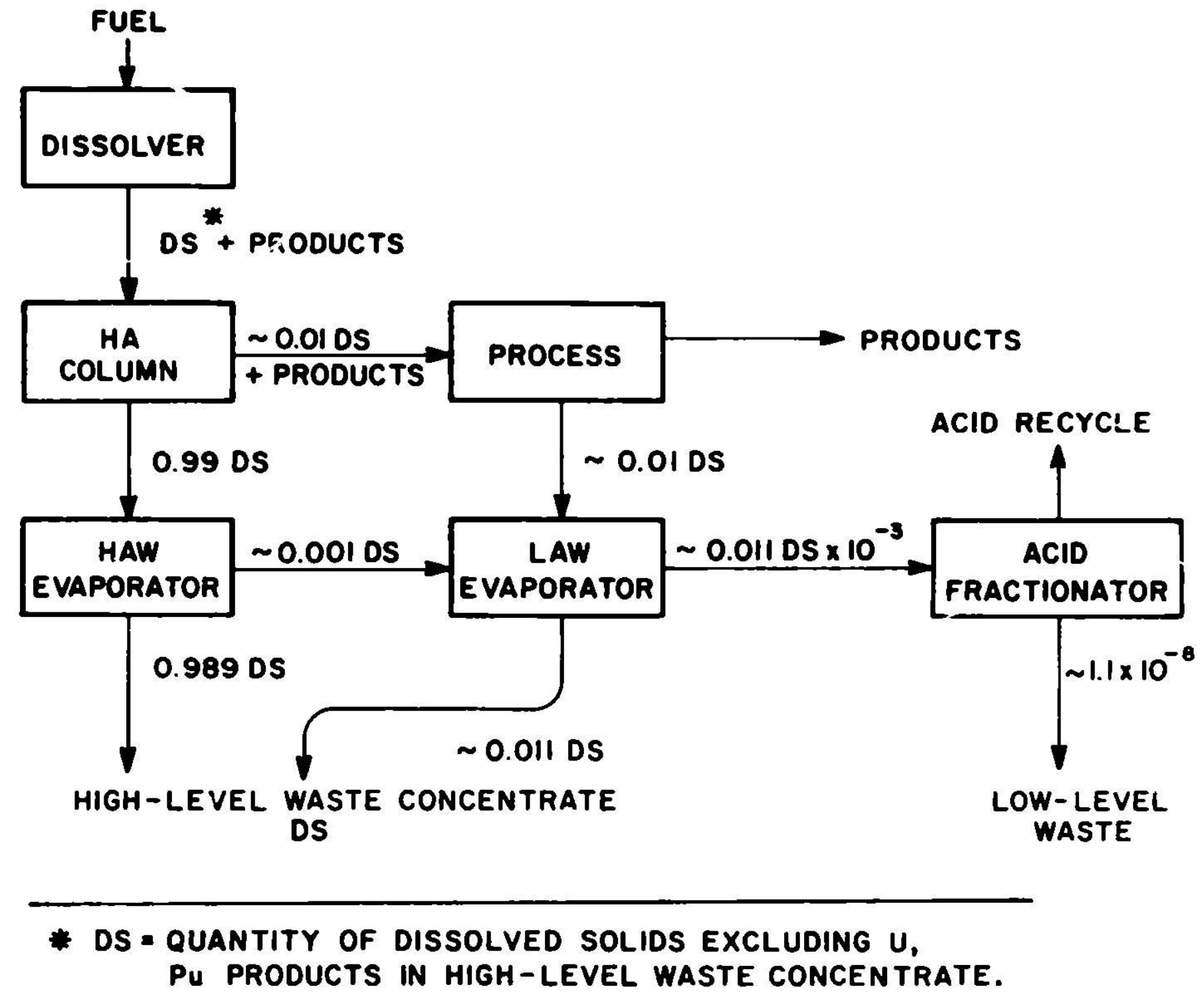

Fig. 3. Abbreviated Murex Flow Sheet; Basis for Estimating Concentrations in Low-Level Waste Assuming Normal Operation and Reference Concentrations in High-Level Waste 


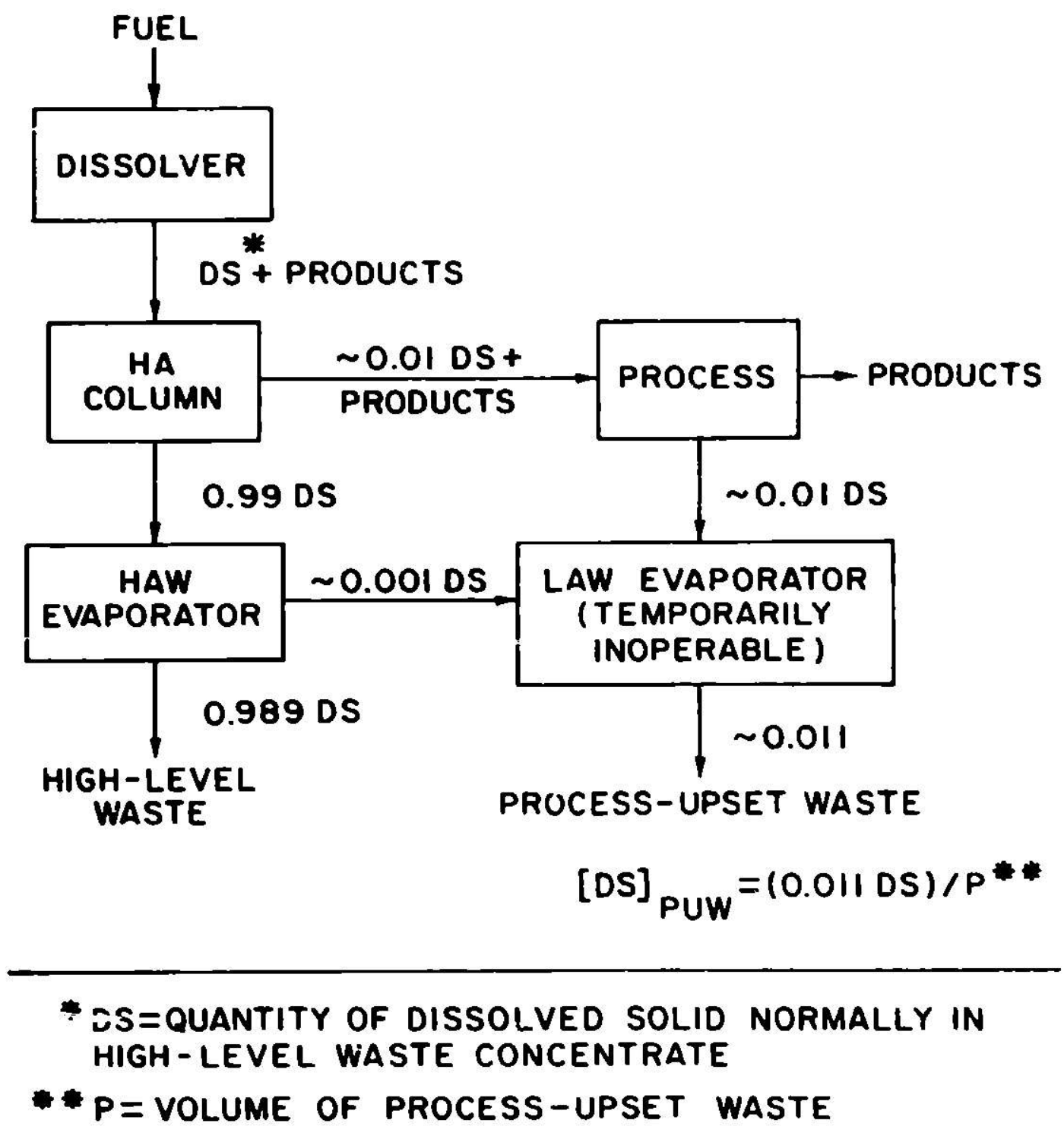

F1g. 4. Abhreviated Purex Flow Sheet; Basis for Estimating Concentrations in a Process-Upset Waste Assuming Reference Concentrations in High-Level Waste 
operation, then the concentrations of dissolved solids in high-level waste and in low-level waste are:

$$
\begin{gathered}
{[D S]_{\mathrm{HAW}}^{*}-\mathrm{DS} / \mathrm{H}_{\mathrm{N}},} \\
{[D S]_{\text {LLAW }}=1.1 \times \dot{10}^{-8} \mathrm{DS} / \mathrm{L},}
\end{gathered}
$$

elloinating DS yields:

$$
[D S]_{\text {LLAW }}=[D S]_{\text {HAW }} \times \frac{\mathrm{H}_{\mathrm{N}}}{\mathrm{L}} \times 1.1 \times 10^{-8} \text {. }
$$

Bimilarly, for the "process-upset" condition (F18. 4),

$$
\begin{aligned}
& {[D S]_{\mathrm{HAW}}=0.989 \mathrm{DS} / \mathrm{H}_{\mathrm{U}}} \\
& (\mathrm{DS}]_{\mathrm{PUW}}=(0.011 \mathrm{DS}) / \mathrm{P}
\end{aligned}
$$

and elininating DS yields,

$$
[D S]_{\text {PUW }}=[D S]_{\mathrm{HAW}} \times \frac{\mathrm{H}_{U}}{\mathrm{P}} \times 1.1 \times 10^{-2}
$$

where $H_{N}$ - volume of high level waste at normal operation

$H_{U}=$ volume of high level waste at process-upset conditions

L - volume of low-level waste at normal operation

$P$ - volume of process upset waste.

The water-balance diagrams for the process flow oheets of the NFS and AGNS plants indicate that $H_{N} / L$ is about $1 \times 10^{-2}$ and that $H_{U} / P$ is about $6 \times 10^{-3}$. These rat 108 and the concentrations of dissolved solids in HAW developed by the Battelle studles of high-level waste solidification (Bonner) are used to calculate the concentration of dissolved sollds in the wastes that would be candidates for deep-well injection. The results of these calculations are lioted In Table 2.

\section{c. Volune}

In managing a wastewater by subsurface infection, one of the most constraining lialtations is the volume that can be infected for the desired length of tine. The intake rate and 11 fe of an Individual well are dependent on the properties of the Injection horizon, which cannot be elgnificantly changed. Injection rate and well life are subject to cholce of a oultable injection preseure. Excesnive preseure vould cause hydraulic fracturing and poselbly consequent danago to confining strata; also, the pressure capacities of infection-wall pumps, tubing, and casing are linited. In most otates, exitur Injection pressures are epecified by regulatory agencies. Pressures are eeldon allowed to exceed about $0.8 \mathrm{pal} / \mathrm{ft}$ of well depth. The Initial preseure required to inject vacte at apecified rate and the rate at which injection preseures Increases with tes can be calculated if the phyeical properties of the aquifer and the waste are known (Section IIL.B.S). The intake rate of wot vaste-injection welle now in use has been found to be lese

(DS) concentrate. 
Table 2. Estimated Concentrations of Dissolved Solids in Low-Level LIquid Waste

\begin{tabular}{|c|c|c|c|}
\hline & & $\begin{array}{l}\text { Lower } \operatorname{Lim} 1 t^{a} \\
\operatorname{Ppm}(w t)\end{array}$ & $\begin{array}{l}\text { Upper Limitb } \\
\text { ppm(wt) }\end{array}$ \\
\hline Inert & $\begin{array}{l}\mathrm{Na} \\
\mathrm{Fe} \\
\mathrm{Cr} \\
\mathrm{NI} \\
\mathrm{PO}_{4}\end{array}$ & $\begin{array}{l}2.3 \times 10^{-8}-1.4 \times 10^{-6} \\
2.8 \times 10^{-7}-7.2 \times 10^{-6} \\
6.2 \times 10^{-8}-2.1 \times 10^{-7} \\
2.9 \times 10^{-8}-1.2 \times 10^{-7} \\
2.4 \times 10^{-7}-2.2 \times 10^{-6}\end{array}$ & $\begin{array}{l}1.4 \times 10^{-2}-8.1 \times 10^{-1} \\
1.7 \times 10^{-1}-4.4 \\
3.7 \times 10^{-2}-1.2 \times 10^{-1} \\
1.8 \times 10^{-2}-7.0 \times 10^{-2} \\
1.4 \times 10^{-1}-1.3\end{array}$ \\
\hline $\begin{array}{l}\text { Fission } \\
\text { Products }\end{array}$ & $\begin{array}{r}\text { Rb } \\
\mathrm{Sr} \\
\mathrm{Y} \\
\mathrm{Zr} \\
\mathrm{Mo} \\
\mathrm{Tc} \\
\mathrm{Ru} \\
\mathrm{Rh} \\
\mathrm{Pd} \\
\mathrm{Ag} \\
\mathrm{Cd} \\
\mathrm{Te} \\
\mathrm{Cg} \\
\mathrm{Ba} \\
\mathrm{La} \\
\mathrm{Ce} \\
\mathrm{Pr} \\
\mathrm{Nd} \\
\mathrm{Pm} \\
\mathrm{Sm} \\
\text { Eu } \\
\mathrm{Gd}\end{array}$ & $\begin{array}{l}8.6 \times 10^{-8} \\
2.4 \times 10^{-7} \\
1.2 \times 10^{-7} \\
1.0 \times 10^{-6} \\
9.1 \times 10^{-7} \\
2.1 \times 10^{-7} \\
6.0 \times 10^{-7} \\
1.0 \times 10^{-7} \\
3.4 \times 10^{-7} \\
2.2 \times 10^{-8} \\
2.2 \times 10^{-8} \\
1.5 \times 10^{-7} \\
7.2 \times 10^{-7} \\
3.7 \times 10^{-7} \\
3.3 \times 10^{-7} \\
7.1 \times 10^{-7} \\
3.2 \times 10^{-7} \\
1.0 \times 10^{-6} \\
2.8 \times 10^{-8} \\
2.1 \times 10^{-7} \\
4.6 \times 10^{-8} \\
3.1 \times 10^{-8}\end{array}$ & $\begin{array}{l}5.1 \times 10^{-2} \\
1.4 \times 10^{-1} \\
7.5 \times 10^{-2} \\
6.0 \times 10^{-1} \\
5.5 \times 10^{-1} \\
1.3 \times 10^{-1} \\
3.6 \times 10^{-1} \\
6.2 \times 10^{-2} \\
2.0 \times 10^{-1} \\
1.3 \times 10^{-2} \\
1.3 \times 10^{-2} \\
9.2 \times 10^{-2} \\
4.3 \times 10^{-1} \\
2.2 \times 10^{-1} \\
2.0 \times 10^{-1} \\
4.3 \times 10^{-1} \\
1.9 \times 10^{-1} \\
6.1 \times 10^{-1} \\
1.6 \times 10^{-2} \\
1.3 \times 10^{-1} \\
2.7 \times 10^{-2} \\
1.9 \times 10^{-2}\end{array}$ \\
\hline Actinides & $\begin{array}{l}\text { U } \\
\text { Np } \\
\text { Pu } \\
\text { Am } \\
\text { Cm }\end{array}$ & $\begin{array}{r}2.7 \times 10^{-7}-2.6 \times 10^{-6} \\
2.0 \times 10^{-7} \\
2.4 \times 10^{-9}-2.4 \times 10^{-8} \\
4.4 \times 10^{-8} \times \\
9.9 \times 10^{-9}-9.9 \times 10^{-8}\end{array}$ & $\begin{array}{l}1.6 \times 10^{-1}-1.6 \\
1.2 \times 10^{-1} \\
1.4 \times 10^{-3}-1.4 \times 10^{-2} \\
2.6 \times 10^{-2} \times 10^{-2} \\
5.9 \times 10^{-3}-5.9 \times 10^{-2}\end{array}$ \\
\hline
\end{tabular}

"Cilculated from the assumption that concentrations in low-level waste are $\sim 10^{-10}$ times the concentrations in high-level waste. The high-level-waste concentrations were taken from the range of reference high-level waste compositions developed in the Battelle Waste Fixation Program to represent the wastes of MFRP, NFS, and AGNS reprocessing plants. Volume $=10^{4} \mathrm{gal} / \mathrm{MTU}$; $\mathrm{HNO}_{3}$ conc $=$ $0.01 \mathrm{M}, 6 \times 10^{2} \mathrm{ppm}(w t)$.

bcalculated from the assumption that the upper 11mit is a "process upset" waste. $i . e .$, the llquid to be disposed of $1 f$ all evaporatora fall except the HAW evaporator. Based on the water balances of the NFS and AGNS plants, the liquid to be disposed of would have concentrations equal to $6 \times 10^{-5}$ times the concentrations in high-level waste. Volume - $10^{4}$ gal/MTU; $\mathrm{HNO}_{3}$ conc - 1-2M, 6-12 $10^{4}$ $\operatorname{ppm}(w t)$. 
than $400 \mathrm{gpm}$, but intake rates can be higher than this in particularly favorable circumstances. The operating $11 \mathrm{fe}$ of an injection wel! may also be related to the volume of injected waste, because the distance injected waste can be allowed to spread laterally may be restricted by law or by other considerations. The storage volume or effective porosity in the vicinity of an injection well can be computed very simply, but disperstion (i.e., mixing with native fluids of che recelving stratum), adsorption, and chemical reaction complicate calculation of the distribution of injected waste. This topic is also discussed in greater detall in Section III.D.3.

It is estimated that the volume of tritlum-bearing wastewater will normally be 10,000 gallons per metric ton of uranium processed per day, or about 7 gallons per minute per MTU. For a large 5-ton-per-day plant, the volume will be about $35 \mathrm{gpm}$. This volume is small enough so that injection can be considered as a practical possibility where pocential injection intervals are known or believed to be present. Therefore a detalled evaluation would be worthwhile for a plant of this size if other local conditions are generally suitable.

\section{Physical Characterlstics}

\section{Density}

The density of the injected wastewater contributes to the injection pressure as a result of pressure associated with the column of water in the well. In some wells, this pressure alone is sufficient to drive the waste into the formation and no pump is needed. In all wells, this pressure component must be included in calculations. Once the wastewater is in the formation, its density affects the manner in which it flows away from the well. Low density wastes tend to float on saline formation waters and to flow up dip, * while dense waters sink and tend to flow down dip.**

The normal low-level waste is predicted to have a total dissolved solids concentration so small (Table 2) that the specific weight of the waste is essentially that of pure water, which 1 s $0.9988 \mathrm{~kg} / \mathrm{l}$ at $0^{\circ} \mathrm{C}$ and $0.9972 \mathrm{~kg} / 1$ at $20^{\circ} \mathrm{C}$. The wastewater resulting from a process upset would be appreclably more dense as a result of 1 ts nitric acid content. It would have a specific welght of about 1.03 to $1.06 \mathrm{~kg} / \mathrm{l}$ (Weast). The spectflc welghts of the wastewaters would be increased slightly if chemicals (e.g., NaOH) were added to neutralize the nitric acid. A greater increase would result from neutralization with solid $\mathrm{NaOH}$ rather than an aqueous solution of $\mathrm{NaOH}$. Neutralization by solid $\mathrm{NaOH}$ would increase the spectflc welght of normal wastewater by 0.0004 $\mathrm{kg} / 1$ and the specific weight of process upset waste by 0.04 to $0.08 \mathrm{~kg} / 1$.

\section{V1scosity}

Viscosity, the ability of a fluid to resist flow, is one of the fundamental properties that determines the rate of flow of a fluid through a porous medium. Furthermore, in wastewater infection, the ratio of the viscosity of the infected water to the viscosity of the formation water (the mobility

\footnotetext{
"Positive angle to the horizon.

**Negative angl: to the horizon.
} 
ratio) has an important effect on the amount of mixing of the injected and interstitial water during travel through the injection reserve' $r$. Mixing is greatly increased when the viscosity of the injected fluid is. iss than that of the interstitfal fluid. The common units of viscosity are the poise and the centipoise (one-hundredth of a poise). Botl: temperature and dissolved solids content can have significant effects on viscosity. Pressure in the range of interest has an insignificant effect on viscosity.

Normal low-level wastewater will have the viscosity of pure water, which is 1.0 centipolse at $20^{\circ} \mathrm{C}$. The viscosity of untreated "Process upset" waste will be about 1.05 to 1.14 times that of pure water at $20^{\circ} \mathrm{C}$, based on the assumption that the solution 1 s $1-2 \mathrm{M} \mathrm{NaNO}_{3}$ as a result of neutralization of the 1-2M HNO 3 with $\mathrm{NaOH}$, and on interpolation of listed visiosities for aqueous $\mathrm{NaNO}_{3}$ solutions (ICT). At its surface temperature during fnjection, the viscosity of normal wastewater may be higher than that of lormation water at the formation temperature but, after the wastewater temperiture changes to the formation temperature, the wastewater will have a lower viscosity because of its negligible chemical content.

\section{Temperature}

The temperature of the wastewater is significant only if it affects its physical or chemical behavior. For example, if the wastewater is corrosive, a high temperature increases 1ts corrosiveness. Also, in some cases, a change in temperature stimulates an undesirable chemical reaction in the wastewater. The viscosily of low-level wastewater will vary inversely with its temperature.

\section{Suspended Solids Content}

Prior to injection of wastewater, suspended solids must be removed to the highest degree practicable because otherwise they w11l be filtered out by the reservoir and plug the formation pores. Suspended solids are present in either normal or "process-upset" waste (but in only extremely small concentrations) as a result of entrainment in the evaporative operations. Nevertheless, filtration prior to injection is recommended to ensure that no particulate matter is carried to the recelving formation.

\section{Gas Content}

Entrained gas bubbles can plug the pores of the injection reservoir just as suspended solids do. It may be necessary to degas some wastewaters, but not LLAW, which should contain little dissolved gas except alr of atmospheric orgin.

\section{E. Chemical Characteristics of Wastewater}

1. pH

Wastewater $\mathrm{pH}$ is related to corrosivity and the possibility of reaction with materials in the subsurface reservolr. Wastes with a low $p H$ have been the principal source of injection system fallure by corrosion. Such wastes also have caused well fallures when as a result of reaction of injected acid with limestone and dolomite in the subsurface reservolt during long periods of erosion, the wellbore has collapsed. However, some reaction with a carbon- 
ate reservolt can be desirable to maintain and even increase the porosity and permeablitity of such a reservolr.

Corresponding to the estimated acid concentration (footnutes, Table 2), untreated low-level waste will ordinarily have an eatlaated pH of about 2 and, In the case of the process upset waste, the pH could be a low as -0.3 . In elther case, the waste will be corrosive and reactive with reservolr rocks and will generally require neutralization prior to injection. If the reservolr is a limestone or dolomite, It might be decided to allow a low pH in the wate to maintain or enhance reservolr porosity and permeabllity. In such a cace, system materials would have to be selected that would resist the corrosive effects of the acidic waste.

\section{Chemical Stability}

Stability of the chenical species in the injected wastewater is desired. Compounds that are not stable at both surface and eubsurface condltIons may form precipltates that could plug pores in the infection reservolr. Such stability problens are not anticlpated for the LLAH =roduced In normal operation, but the estimated concentrations of some netale in the hypothetical process-upset waste (upper-limit colun, Table 2) exceed their colubilities In water at pH 7. For exalple, iron hydroxide, which would furs if the wiste were neutralized with a hydroxide before infection, is virtually in:oluble. No other problems of atabllity are apparent for the vastes characterized by Table 2.

\section{Chenical Reectivity}

Hastevater can react with eaterials In the eachanical eyetew, equifer fluids, and aquifer einerals. To predict poselble reactions, Information is needed on the compostion of the vestewater (defined in Tuble 2 and a daecribed above) and the aterials of construction, the chealstry of the squifer flutds, the aineralogy of the injection horizon, and the subsurface temperature and pressure.

Corroeive atteck by vastewater on extels in Injection systes has

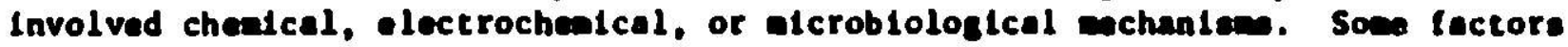
that encourage electrochentcal corrosion of eteel are diesolved oxysen, dissolved ealts, Lov ph, elevated temperature, and hich tlov rate of the corrodlas water. Of these factore. Iov ph of the untreated lon-lovel vastewater is the wet elemificent conalderation. In the presence of oxidizine ecids, such as the $\mathrm{HNO}_{3}$ in lon-1evel vatewater, corrosion proceeds in the eheence of discolved oxysen. If the veste ts neutralleod, the only eleniflcent egent of corrosion ts diseolved oxygen. Microblological corrosion is not efenticent In the present application.

A poselble problen Involving reactivity of the wateveter vith wete

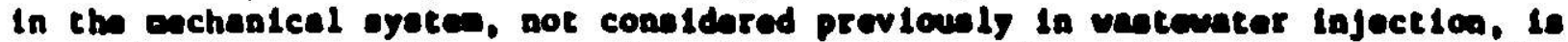
the enlective depoettion of rediosctive etele in place of the laste evele in the syoter. This procese would caune the eyete componente to becons redsoactive and would poselbly present sen opectal problem in thatr handilns. lioted oxidat lon-reduction potentiels for ectd colution (Let Ienr) Indicate that although eas of the nonradlonctive const tutentes llated in rable 2 ay be expected to replece $1 \mathrm{ron}, 0.0 .$, Pd, As, Mo, and Cd, the only redloective 
Isucupe expected to replace tron to Ru, present as $10{ }^{3} \mathrm{Ru}$ and $10 \mathrm{e}^{\mathrm{Ru}}$. An upper Itmle for the effects of ruthenlua accumelation can be estanted from the LLAH concentrations of Table 2 by assulng that rutheniun quaneleatively roplaces Iron in well equipacent, nuglecting the repression of clice repliccement reaction by the iron alteady prosent in the LLAW. The accueulation rates estimated on

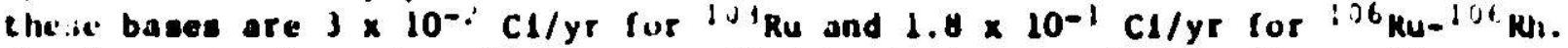
The ingeation hazard vould be controlled by devising sulcable diateintiling procedurea. The garemo hazard, huwver. Is not expected to be great on the basls of the follwolng conslduratlow: The exposure rate to an leutrople polint source of game.t radiation can be approximated (Stephenson) by

$$
\text { r/hr (at I } f(t) \cdot 6(\text { Nu. of curlea) (energy of ganas). }
$$

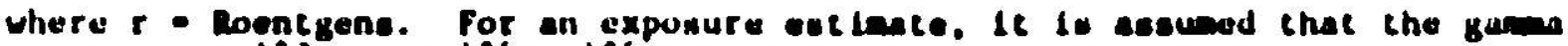
apecterum of $103_{R u}$ and 106 Ru- 106 Rh buth Involve energles of aboul $0.6 \mathrm{MeV}$ (liederer). Therefore.

$$
\text { r/hr (at } 1(t) \cdot 3.6(\text { No. of } C l) \text {. }
$$

Thus, for an uppor liest ost late, If the ruthenlue accuaslated at a point in well equipent for 1 year, the exposure rate, neglecting all shleldiog effects, vould be $3.6\left(3.1 \times 10^{-2}+1.8 \times 10^{-1}\right) \cdot 0.8 \mathrm{r} / \mathrm{hr}$ et $1 \mathrm{fl}$. or In other teras, about $7 \times 10^{1} \mathrm{erem} / \mathrm{hr}$ at 1 ester. At chls rete, Iadividual exposure would be oaslly controllable when li to consldered that the rediation protect ton ulandard of whole-body exposure is 3 ree per calundar querter (AECH 0s26).

Resctlone of Injected vith laterectelal wacer conetlewente that form preclpitates are undesirable beceuse the precipltatee an plus the pores of the Inject ion horleon, reduc las porostey and perneabllity. Seln and Hulse

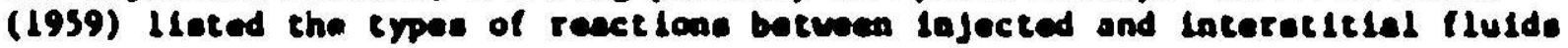
that can cause pluselas preclpltaces to tore-(l) prectpleation of alkallne

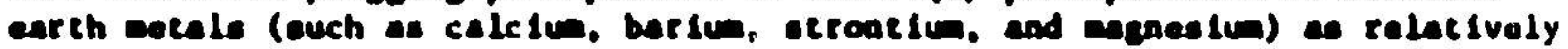
insoluble carbeances, sullates, ortbophosphates. Ilworldes, and hydroxides;

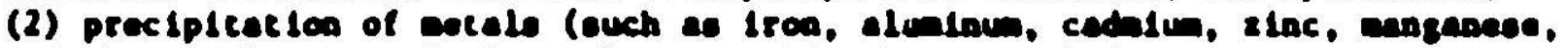
and chroniu) as lnsoluble carbenetes. Blcarbonetes, hydroxldea, orthophosphates, and culfliden; and (3) preclpitation of oxldation-reduct ton reaction producte.

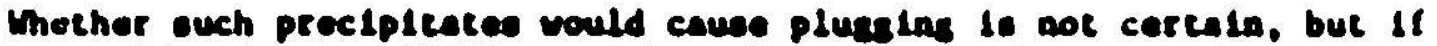

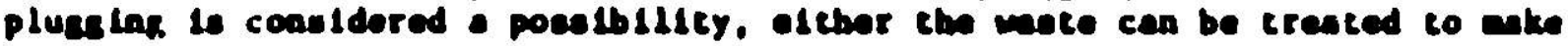
It noareace ive or nonfacet lve uater cas be injected abead of tha waste to form a buffer betwen the wote and the aqulfer weer (Warner 1966).

The diseolved collde coateat of boch the norenl whll and the hypothat tcal procese upeet wete 10 co 100 (Table 2) chat prectplention of reaction producte chould not be a proble. For aneple, barlen eulfate, one of the

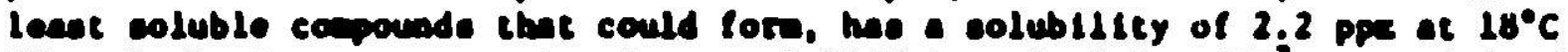

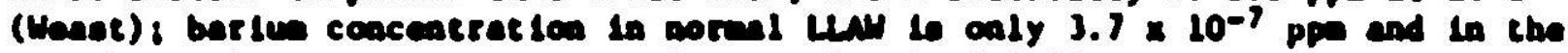
hypothat leal procese upeet wete to at a level of 0.22 poe.

Aleo, the relatively ebort wall-11le of $10 \mathrm{~J}$ m (3s daye) could requite only a adest decey portud to reduce operator exposure eubstant lally. 
Reaction of the luw-level waste with minerals of the geologic formation is more likely. In the absence of neutralization prlor to infection, che waste would react with limestone or dolomite aquifers or with carbonatecemented sandetones in the following way:

$$
\begin{gathered}
2 \mathrm{HNO}_{3}+\mathrm{CaCO}_{3} \rightarrow \mathrm{CO}_{2}++\mathrm{Ca}\left(\mathrm{NO}_{3}\right)_{2}+\mathrm{H}_{2} \mathrm{O} \\
4 \mathrm{HNO}_{3}+\mathrm{CaMg}\left(\mathrm{CO}_{3}\right)_{2}+2 \mathrm{CO}_{2}++\mathrm{Ca}\left(\mathrm{NO}_{3}\right)_{2}+\mathrm{Mg}\left(\mathrm{NO}_{3}\right)_{2}+2 \mathrm{H}_{2} \mathrm{O}
\end{gathered}
$$

As 1o discussed above (II.E.1), this reaction can be a beneficlal one if it is allowed on a controlled basis. The benefits are greater aquifer porosity and permeability. Dlsadvantages of infecting unneutralized or partially neutralized waste are:

(a) The need to design the mechantcal system to resist the corrosive acid waste;

(b) Possible eventusl problems with borehole sloughing as the rock structure is weakened;

(c) Deterloration of carbonate cap rocks, particularly around the wellbore trself.

The other most significant possible reaction of low-level wastewater with elnerals of the receiving aquifer 18 sorption of cations and, to a small extent, anions by clay minerals. Sorgtion is a mechanisw whereby lons (including those of radionctive lsotopes) are $r$ oved from the liquid and retained by the clays. The lons would be retained in the aquifer if the liquid should escape or be removed deliberately. In aneral, bivalent cattons are adsorbed in preference to sonovalent ones and trivalent in preference to bivalent ones. For example. If codium is the cation present in nature, it is replaced by an ton ouch as calclua; calciu, in curn, is replaced by aluminum. However, Ion concentration aleo deternines relative replaceability, and cations listed in Table 2 are present in very low concentrations. The mechanics of sorption of lons from low-level waste by clays in natural aquifers cannot be predicted, other than to say that corption is a possible reaction mechanism. The number of lons present is so great that the sequence in which they would be selectively adeorbed by the claye is not known. Also, mineralogical characteristics of claye vary, a do lons naturally adsorbed, so that clays from different locatione do not neceserarlly behave sintlarly.

In oumary, the chealcal characteristics of wastewater to be injected affect the likellhood of well equipant corroding and of reactions occurring with alnerals or native fluids of the recelving aquifer that result in changed parteblilty of the equifer. The probable chemical characteristics of LLAW have been anslyaed and shou that, except for the possible accumulation of radlosctive rutheniu in well equipeant, no problem related to chemical reactivity of watewater are anticlpated that have not already been solved routinely by previou practice in the injection of industrial wastes. 
F. Toxiciliy

\section{Chemicals}

Toxic chemicals, as defined in the Federal Water Pollution Control Act Amendments of 1972, are "those pollutants or combinations of pollutants, including disease-causing agents, which after discharge and upon exposure, ingestion, inhalation or assimilation into any organism, either directly from the environment or indirectly through food chains, will, on the basis of information avallable to the Administrator, cause death, disease, behavioral abnormalities, cancer, genetic mutations, physiological malfunctions (Including malfunctions in reproduction) or physical deformations, in such organisms or their of fspring." As required in the 1972 act, a list of toxic pollutants was to have been assembled by the EPA, but at the time of writing (mid-1975) this list is not yet avallable.

The sources of information on concentration limits of sume toxic metals present in low-level wastewater are the Putilic Health Sirvice drinking water standards (USPHS 1962) and the recommendations of the Department of Interior (LSDI). In these publications, the range of recommended permissible limits for metals that are present in low-level wastewaters 1s: 1ron, $0.3 \mathrm{mg} / 1$; barlum, 0.05 to $1.0 \mathrm{mg} / 1$; cadmlum, $0.01 \mathrm{mg} / 1$; sllver, $0.05 \mathrm{mg} / 1$; and chromlum, $0.05 \mathrm{mg} / 1$. In comparison, the concentrations $\mathrm{ppm}$ or $\mathrm{mg} / \mathrm{l}$ in normal LLAW (Table 2) are much lower than these recommended 1 imits, i.e., 1ron, $2.8 \times 10^{-7}$ to $7.2 \times 10^{-6}$; barlum, $3.7 \times 10^{-7}$; cadmlum, $2.2 \times 10^{-8}$; silver, $2.2 \times 10^{-8}$; and chromium, $6.2 \times 10^{-8}$ to $2.1 \times 10^{-7}$. The other metals listed in Table 2 are generally so rare in drinking water supplies that either they are not included in the sources 1 isted above or they are not toxic to humans in the concentrations likely to be encountered. According to McKee and Wolf (1963), nickel, rubldium, ruthenium, strontium, sllver, ceslum, lanthanum, and cerium are not known to be highly toxic to humans. In the very low concentrations shown in Table 2, they appear to present no health hazard. Uranium and many of 1 ts salts are reported to be highly toxic, but the literature does not always confirm this observation (McKee). The Division of Industrial Hygiene, Ontar1o Department of Health, has suggested a maximum allowable concentration for neutral uranium in drinking water of 500 to 100 micrograms per liter (McKee). This is considerably higher than the concentration present in the normal neutral low-level effluent.

Comparison of data in Table 2 with recommended limits indicates that elements in the normal low-level wastewater present no obvlous health hazard from a chemical standpoint except for nitrate. It should be noted that the comparison of the coricentration in LLAW with the recommended limits for lowlevel wastewaters Implies the hazards involved in an unlikely course of events Involving escape of LLAW from its confining aquifer into the blosphere.

Nitrate is present in the normal low-level wastewater at an estimated concentration of about $620 \mathrm{mg} / 1$, which $1 \mathrm{~s} 13.8$ times the recomended $11 \mathrm{mit}$ of $45 \mathrm{mg} / 1$ in the Public Health Service drinking water standards (USPHS 1962). In the process upset waste also, nitrate would be the most objectionable nonradioactive constituent, being present at a concentration of 63 to $126 \mathrm{~g} / 1$, or 1380 to 2760 times its recommended limit in drinking water. 
Iron, barium, cadmium, and chromium are present in "process-upset" waste in excess of the recommended amounts, but not greatly so, and it is not anticlpated that the "process-upset" waste would be infected except temporarily and in the very rare situations where all evaporators except the HAW evaporator falled.

\section{Radioactivity}

The contribution of radioactivity to the toxicity of LLAW might best be considered by comparing estimated concentrations of various radioactive 1sotopes in LLAW with the radiation concentration guldelines (RCG) listed in the U.S. Code of Federal Regulations (10CFR20) for release to an uncontrolled area (Appendix B, Table II). * The concentrations of radioactive isotopes in LLAW have been estimated from the discharges in C1/sec projected for the condensable waste stream of the Barnwell plant (AGNS) and the assumption that these discharge lsotopes would be assoclated with a waste fluid flow rate of $50,000 \mathrm{gal}$ in a $24-\mathrm{hr}$ period. The estimated concentrations and their ratios to guideline values are presented in Table 3 . The concentrations in tire conceptual LLAW developed here, exceed the guidelines for only three 1sotopes, by factors of about 2.100 for ${ }^{3} \mathrm{H}$, about 17 for ${ }^{131} \mathrm{I}$, about 10 for ${ }^{12}$ ' $^{1} \mathrm{I}$, and about 2 for ${ }^{90} \mathrm{Sr}$. In the case of the hypothetical process-upeet waste, on the other hand, the corresponding factors would each be higher by about $6 \times 10^{5}$, except that the factor for tritlum would remain about 2100 .

\section{G. Summary}

The properties of the waste fluid to be injected into a deep well are important determinants of the procedures needed for pre-injection treatment of both waste and the receiving stratum, and of the design, capacity, and materials requirements for equipment. Because of the unavallability of information representing typical experience of the characteristics of LLAW from commercial reprocessing of spent nuclear fuels, a reference composition of LLAW including dissolved solids was derived from (1) predicted compositions of high-level waste concentrations and (2) the assumed decontamination factors for the operations that essentlally split HAW into HAW concentrate and LLAW. The concentrations of radioactive 1sotopes was assumed to correspond to those predicted by the Barnwell environmental report (AGNS).

The volume rate of generating LLAW at a $5 \mathrm{MTU} /$ day fuel-reprosessing plant 1s well within the range of feasibility for subsurface infection. The estimated 35 gpm rate 18 modest compared with that for many other industrial waste injec-tion wells. The physical characteristice of LLAW are not expected to generate spectal problems, judging from the low concentrations of solutes; it is assumed, however, that filtration before injection 18 desirable. Problems stemming from chemical instability, espectally chemical reactions resulting in the precipltation of solids that would plug aquifer pores, seems unlikely for LLAW. The main constituent, nitric acid, would probably be neutralized before injection to reduce the effects on equipment and on aquifers having compositions

\footnotetext{
* The RCG, $3 \times 10^{-3} \mu \mathrm{Cl}{ }^{3} \mathrm{H} / \mathrm{ml}$ has been commonly referred to in the past as "the drinking water 11m1t." It should be noted that the U.S. Environmental Protection Agency has recently proposed a limit of $2 \times 10^{-5} \mu \mathrm{Cl}{ }^{3} \mathrm{H} / \mathrm{ml}$ for drinking water (USEPA 1975)
} 
Table 3. Comparison of Concentrations of Radioactive

Isotopes in L.LAW with Radiation

Concentration Guidelines

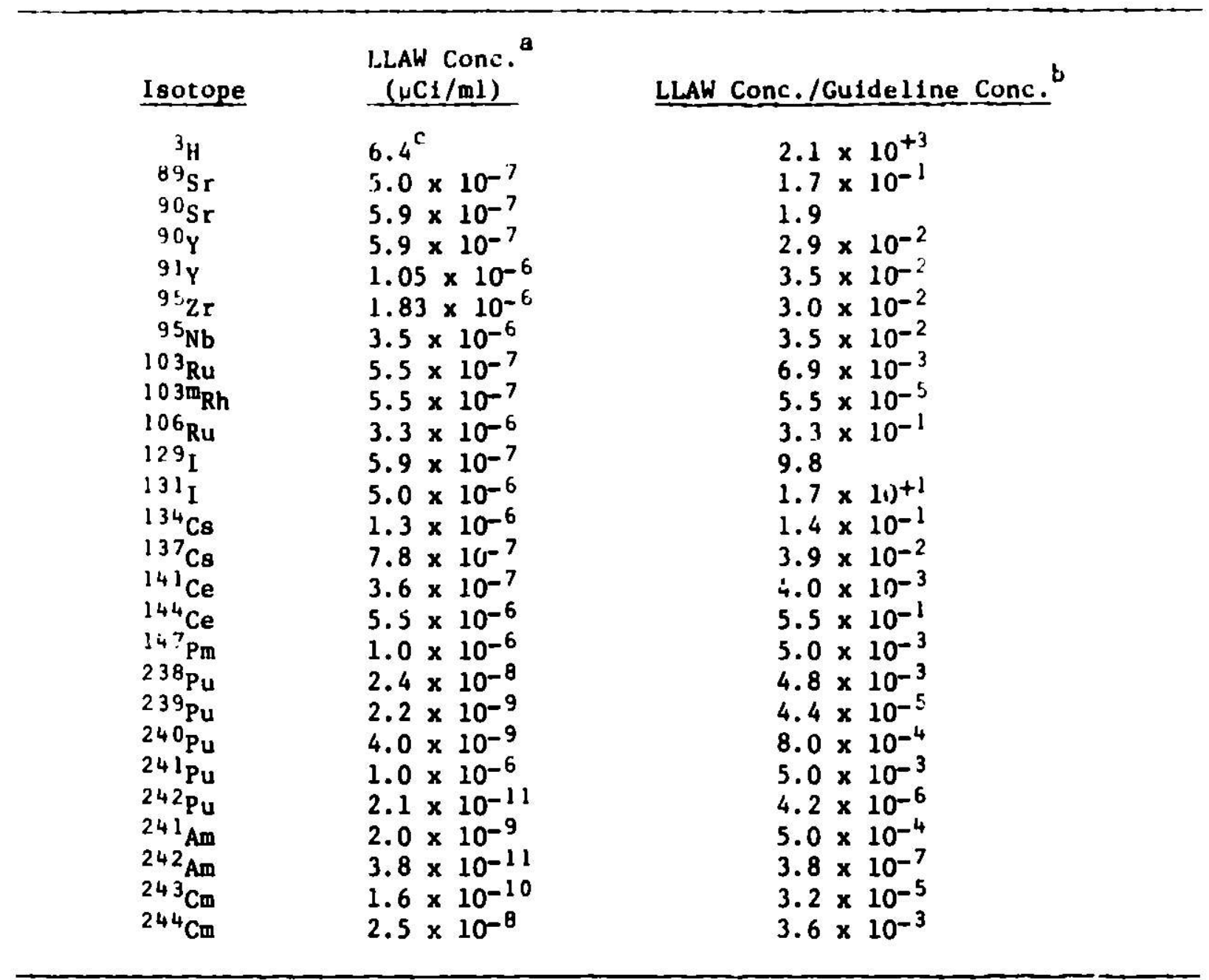

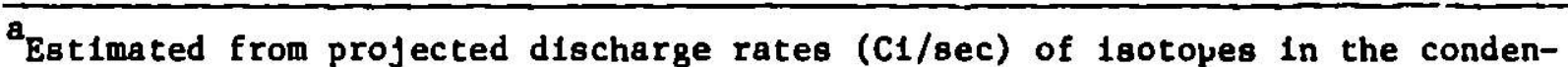
sable waste stream of the Barnwell Nuclear Fuels Plant (AGNS) and the assumption that the lootopes would be associated with a waste fluid flow rate of 50,000 gal per 24-hr perlod. The activity basis includes a thruughout of 5 $\mathrm{MTU} /$ day (1500 MTU/yr), a fuel burnup of 32,000 MWd/MTU, and a cooling time of 180 days. These concentrations are meant to be representative of the normal LLAW rather than the hypothetical process-upset waste (II.B.3). Because of the volatility of lodine, the concentrations listed fot its lsotopes here may be conservatively high.

${ }^{b}$ Code of Federal Regulations (1OCFK20), values for concentrations in water acceptable for release to uncontrolled area, Appendix B, Table 2.

This concentration 18 based on the estimated $C 1$ release rate into the condensible waste stream of BNFP predicte; in reference AGNS and the assumption, tiken from reference ORNL, that the volume of LLAW would be $10^{4} \mathrm{gal} / \mathrm{MrU}$. Another estimate based on different predictinns for the tritium content of opent fuel and the volume of LLAW $1810 \mu \mathrm{Cl}{ }^{3} \mathrm{H} / \mathrm{ml}$ (ERDA). Somewhat higher concentrations, 20 to $30 \mu \mathrm{Cl}{ }^{3} \mathrm{~h} / \mathrm{ml}$, result from eatimates based on a lower LLAW volume, about $5 \times 10^{3} \mathrm{gal} / \mathrm{MTU}$, suggested by recent evaluations of the BNFP flowsheet (Burger). 
based on $\mathrm{CaCO}_{3}$. A potential for chemical toxicity exista alnce the nitrate Ion concentration exceeds the Publlc Healih Service drinking water standarda. A potential for radiotoxicity exista ince $131_{1}, 129_{1}$, and ${ }^{9} \mathrm{Sr}$ concentrations exceed the Radiation Concentration Guidelines (10CFR20) by factors ranging from 2 to less than 20 and the ${ }^{3} \mathrm{H}$ concentration (of greatest interest in the present work) by a factor of 2100 .

\section{SITING OF A WASTF-INJECTION WELI.}

\section{A. General Considerat Lons}

The cholce of a site for deep-well injection 18 one of the most important factors affecting the feastbility of tritium disposal by deep-well injection of LLAW. It Includeg such considerations as the geologic properties necessary for containing and transmitting flulds; prospecting and testing for these propertise; predictions (based on these properties) of the behavior of contalned fluids; and existing inforwation on the geographic location of suitable geology in the U.S.

Examination of a site for a wastewater injection well begins at the regional level, then is narrowed to the vicinity of the site, and finally focuses upon the immediate well. Outlined in Table 4 are factors to be. considered in site evaluation reglonal and local levels.

Experience has shown that nearly all types of rocks can, under favorable c1rcumbtances, have sufficlent porosity and permeablilty to yield or accept large quantities of fluids. Sedimentary rocks, however, esperially those deposited In a marine environment, are most likely to have the geolugic characteristics sultable for waste-injection wells. These characteristics are (1) an infection zone with sufficlent permeabili:y, porosity, thickness, and areal extent to act as a liquid-storage reservolr at oafe inject ion pressures, and (2) an injection zone that is below the level of fresh-water circulation and is confined against vertical movement by rocks tha'c are, for practical purposes, Impermeable to vaste 1 :quids.

Confinement of injected wastes against vertical movement into upper, fresh-water aquifers 18 important not only for the protection of usable water resources, but also to avold contaminat ion by waste of developed and undeveloped overlying and underlying deposits of hydrocarbons and valuable minerals. The effect of lateral movement of waste on such natural resources also must be considered.

The minimum depth of burial, the neceseary tnickness of confining strata, and the minimum saliaity of water in the infection zone have not been eatablished quantitatively. It may be possible to specify these constrainte on!y for Individual cases, as has been done in the past.

The minimum depth of burial can be considered to be the depth at which a conilned saline-water-bearing zone 18 present; it may range from a few hundred feet to several thousand feet.

The mininum salinity of water in the Injection zone will be specified by regulatory agencles at level considered neccseary to protect usable 
Table 4. Factors to be Considered for Geologlc and Hydrologic Evaluation of a Site for Subsurface Waste Injection

Reglonal Geologic and Hydruloglc Framework

Physlography and general geology; structure; stratigraphy; groundwater; mineral resources; Beismictity; hydrodynamics.

\section{Local Geology and Geohydrology}

A. Structural Geology

B. Geologic Description of Subsurface Rock Units

1. General rock types and characteristics

2. Description of infection horlzons and confining beds

Lithology; thickness and vertical and lateral distribution; areal distribution; porosity (type and distribution as well as amount); permeability (same as areal distribution); reservoir temperature and pressure; chemlcal characteristics of reservoir fluids; formation breakdown or fracture pressure; hydrodynamics.

3. Groundwater aquifers at the site and in the vicinity.

Depth; thickness; general character; amount of use and pistential for use.

4. Mineral resources and their occurrence at the well site and in the Immediate area.

011 and gas (Including past, present, and possible future development); coal; brines; other. 
groundwater resources. Other chemical and physlcal properties of subsurface water must be known 1 il order to compute fluid flow rates and directions, and in order to anticipate any chemical reactions between aquifer fluids and injected wastewater. The lithology of the aquifers and aquacludes must also be evaluated to anticipate possible chemical reactions with injected wastewater.

Aquifer thickness and permeability that permit the necessary injection of fluid at a desired rate can be estimated from equations developed by petroleum engineers and groundwater hydrologists. The geometry of the injection zone also determines its sultability for waste injection. Thus, a thick lens of highly permeable sandstone might not be satisfactory for injection if its areal extent is small and it is surrounded by Impermeable beds, because pressure bulldup in the lens would be rapid in comparison to pressure bulldup in a "blanket" sandstone.

It might be desirable in some cases to inject wastes into a geologic structure known to be synclinal, i.e., sloping from opposite directions to form a basin-like fold. Under favorable conditions, this practice would help to ensure the confinement of the waste within a specifled area. Wastes of relatively high specific gravity stored in closed synclines would not tend to leak upward into fresh-water-bearing strata and would not move laterally into hydrocarbon-bearing anticlinal features under hydrostatic.conditions.

In addition to stratigraphy, structure, and rock properties, which are factors routinely considered in subsurface studies, aquifer hydrodynamics may be significant in the evaluation of waste-injection well sites. The entrapment of fluids is modified under hydrodynamic conditions. The presence of a natural hydrodynamic gradient in the injection zone will cause the infected waste to be distributed asymetrically about the wellbore and to be transported through the aquifer even after injection has ceased.

Hydrodynamic dispersion, the mixing of displacing and displaced fluids during movement through porous media, may cause much wider distribution of waste in the injection zone than would otherwise be anticlpated. Dispersion is known to occur in essentially homogeneous isotropic sandstone; and it could lead to particularly rapid lateral distribution of waste in heterogeneous sandstone and fractured or cavernous strata. On the other hand, sorption of lons by aquifer minerals retards the spiead of lonic waste constituents from the injection site.

Accurate prediction of the movement of waste in most natural aquifers with the mathemstical modes now avallable are satisfactory only under restrictive, simplified physical circumstances. Even if knowledge of th physics of fluid movement in natural aquifers were conslderably more advanced, determination of the phyginal parameters that characterize an injection zone would remain a problem if few subsurface data were avallable. These restrictions do not, however, preclude quantitative estimation of the rate and direction of movement of infected waste.

The maximum pressure at which liquids can be injected without causing hydraulic fracturing may be the factor limiting the intake rate and operating 
life of an infection well. The infection pressure at which hydraulic fracturing occurs is related directly to the magnitude of regional rock stress and to the natural strength of the injection zone.

Other considerations in the determination of site sultabilfty are (1) the presence of abnormally high natural fluid pressure and temperature in the potential injection zone that may make injection difficult or uneconomical; (2) the local incidence of earthquakes that can cause movement along faults and damage to the subsurface well factlitles; (3) the presence of abandoned, improperly plugged wells that penetrate the injection zone and provide a means for escape of injected waste to groundwater aquifers or to the surface; and (4) the potential of the area for earthquake activity that could be triggered by wastewater injection.

\section{B. Factors in Site Evaluation}

\section{Stratigraphic Geology}

Sandstone, limestone, and dolomite are commonly porous and permeable enough in the unfractured state to be suitable infection zones. Naturally fractured limestone, dolomite, shale, and uther rocks also may be satisfactory. Sedimentary rocks with solution or fracture porosity may be preferable to rocks with intergranular porosity because commonly solution and fracture flow channels are relatively large in comparison with intergranular pore: and are not, therefore, as likely to be plugged by suspended solids in the injected liquids. Waste infection Into 11mestone and dolomite has proved particularly succesaful in sore places because the permeability of these rocks can be improved greatly with acid treatment.

Unfractured shale, clay, slate, anhydrite, gypsum, marl, and bentonite have been found to provide good seals against the upward flow of fluids. Limestone and dolomite may be satisfactory :onfining strata, but these rocks commonly contain fractures or solution channels; their adequacy must be determined carefully in each case.

Regional stratigraphy is determined by the use of outcrop and borehole data which have been interpreted and are generally presented in the form of columnar wections, isopachous maps and cross sections.

The basic data unit used in studies of stratigraphic geology is the columnar section, which is a graphic representation of the sequence, thickness, 1tthology, and relationship of the rock units at a location. A generallzed columnar section may be prepared which shows these parameters for a region-an example, for northeastern Illinois, is shown in Fig. 5. Columnar sections are prepared with cores, cuttings, and geophysical loge from boreholes and from outcrops, wherever present. Some possible infection horizons in Fig. 5 are Indicated by the fact that they are being used for natural gas storage. Of these possible infection units, the Mt. Simon formation 18 the deepest and 18 overlain by the Eau Clafre formation, which may contain confining shale beds. On the other hand, the St. Peter formation 18 the shallowest and 18 overlain by 11 mestones and dolomites, which are less dependable as aquitards. Therefore, the St. Peter formation woulc have a lesser potentlal for wastewater injection. 


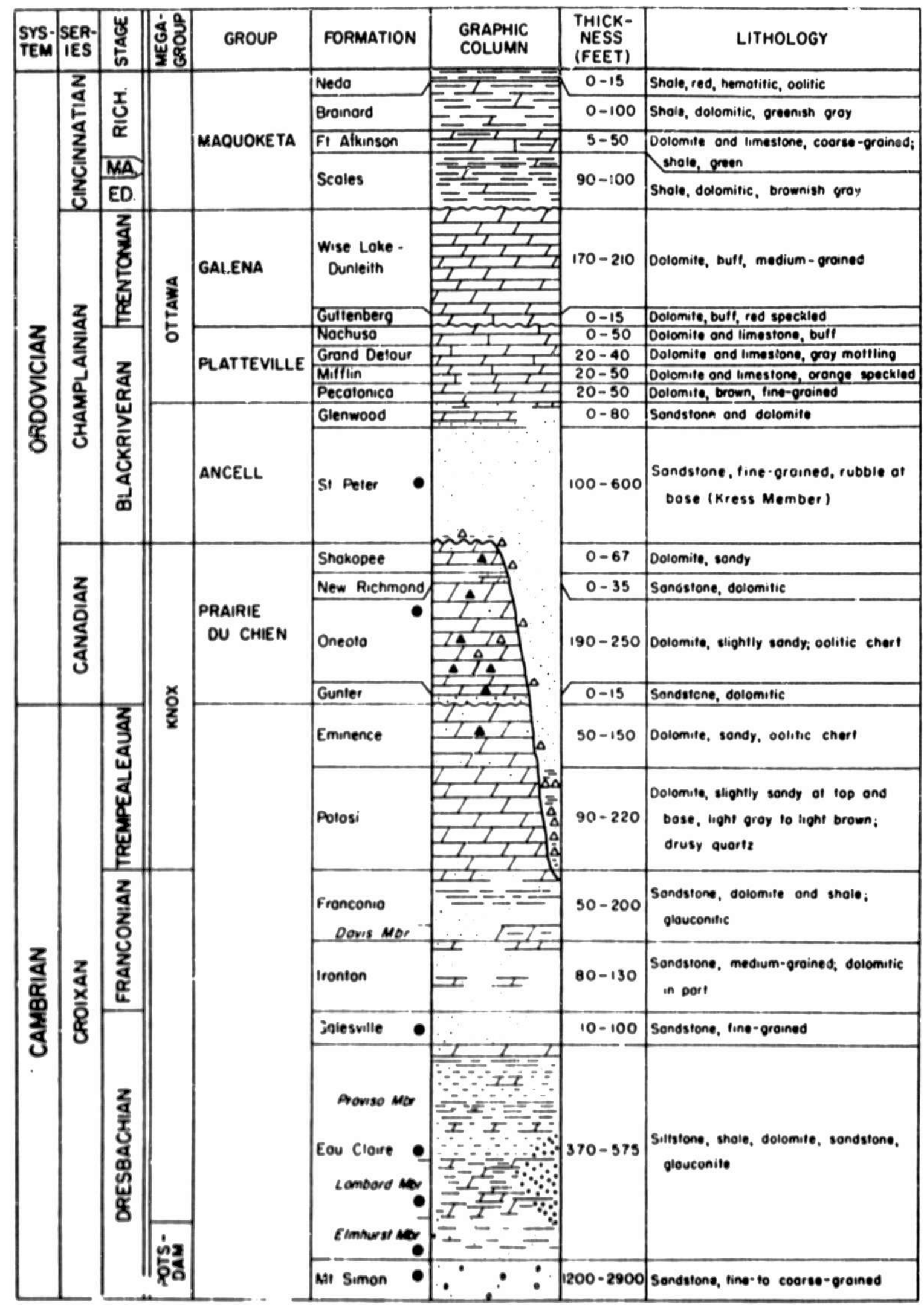

Yg. 5. Example of Goneralized Columnar Section: Cambrian and Ordovician Strata in Nurtheastern Illinols (After Buschbach). Black Dots Indicate Gas Storage Zones. Abbrevlations: Ed. - Edunian; Ma. Mavavlllian; Rlch. - Riclimondlan. 
Isopachous maps indicate, by contour lines, the varying thickness of a strat $\$$ graphic unit. For example, Fig. 6 presents an isopachous map of the Mt. Simon formation in Illinois, showing that this sanistone unit varies in thickness from 0 to 2,000 feet within that state. Other factors being equal, locations where the Mit. Simon formation is thickest have the greatest potential for wastewater injection.

The facies of a stratigraphic unit are its laterally varying aspects, such as 1ithology, fosstl content, and so forth. For example, the Eau Claire formation, which overlies the Mt. Simon formation, consists of a mixture of slltstone, shale, dolomite, and sandstone in northeastern lilinois (Fig. 5), but passes, by facies change, eastward into sandstone, shale, or dolomfte at varlous locations in the east-west cross section, as shown in F1g. 7 .

3ome types of factes maps are ratio maps, percentage maps, and 1solith maps. These facies maps are $\mathrm{d} / \mathrm{f}$ ferent ways of showing the relative amounts of the various lithologles in a rock unit or units. The ratio and percentage maps show contours of the ratios or percentages of the aggregate thicknesses of lithologic classes.

Figure 8 is presented as an example of a lithologic ratio map, showing the relative ratios of sandstone, shale, and dolomite in post-Mt. Simon preKnox rocks in Ohio. This figure generally shows that this group of rocks changes from a sandy facles in western Ohlo to a dolomite facles in eastern Ohio. The rocks depicted in Fig. 8 are equivalent to the Eau Claire formation in Fig. 5 and 7. Without further information, Fig. 8 shows that the Eau Claire formation becomes less promising as a confining unit as it is traced eastward across ohto.

Local strat Igraphy $1 \mathrm{~s}$ first profected from regtonal data such as that discussed above, before drilling of a well, then is determined in detall for the well when it is drilled. As prevlously mentioned, the means of displaying the stratigraphy of a well is the columnar section.

\section{Structural Geology}

Structural geology is concerned with the folding, faulting, and fracturing of rocks and the geographlc distribution of these features. One means of showing regional structural geologic features is a map which includes areas or lines of major features. One example of this means of presenting structural features is the map for the ohio River Basin shown in Fig. 9. Major synclinal basins (i.e., those involving downwarps of the crust) shown in F1g. 9 are the Appalachian basin, the Illincls basin, and portions of the Michigan basin and the Mississippi embayment. The Cincinnati arch and Its continuations, the Kankakee and Findlay arches to the north and the Nashville dome to the south are major uplifts separating the basing. The outcrop of crystalline rocks that forms the core of the Appalachian Mountain ranges represents a major anticlinal fold that bounds the Appalachian basin on the southeast. Each of the major folds has many smaller ones superimposed upon $1 t$. The southeastern portion of the Appalachian basin 18, in particular, defirmed by many smaller folds as indicated in the figure. Also, a zone of very intense and complex folding, faulting and fracturing, ranglug from a few miles up to about $80 \mathrm{miles}$ in width, borders the northesst-southwest trending 


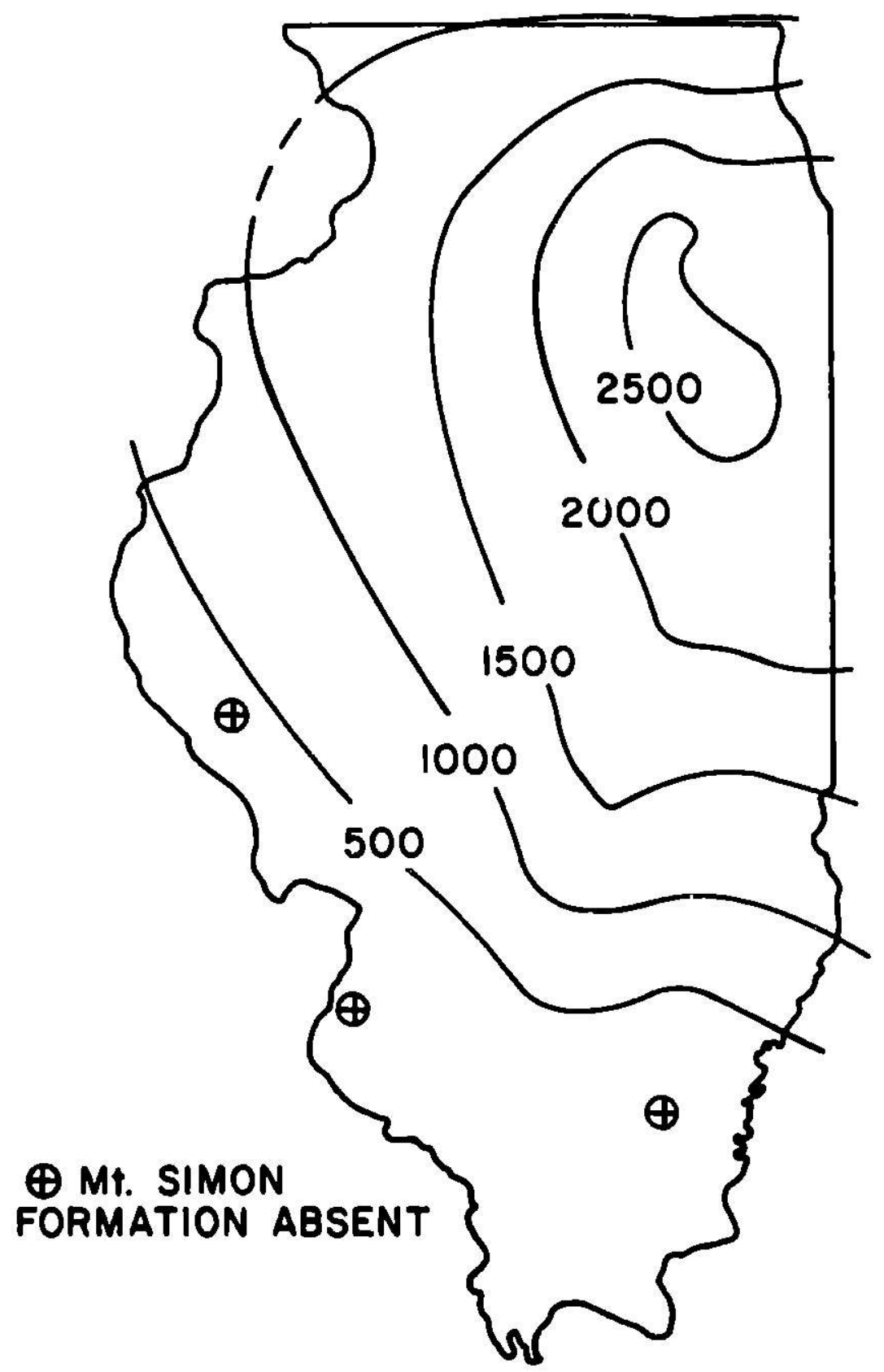

SCALE

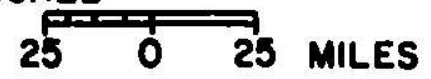

Fig. 6. Example of Isopachous Map: Thickness in Ft of the Mt. Simon Formation in Illinols (Buschbach 1975) 


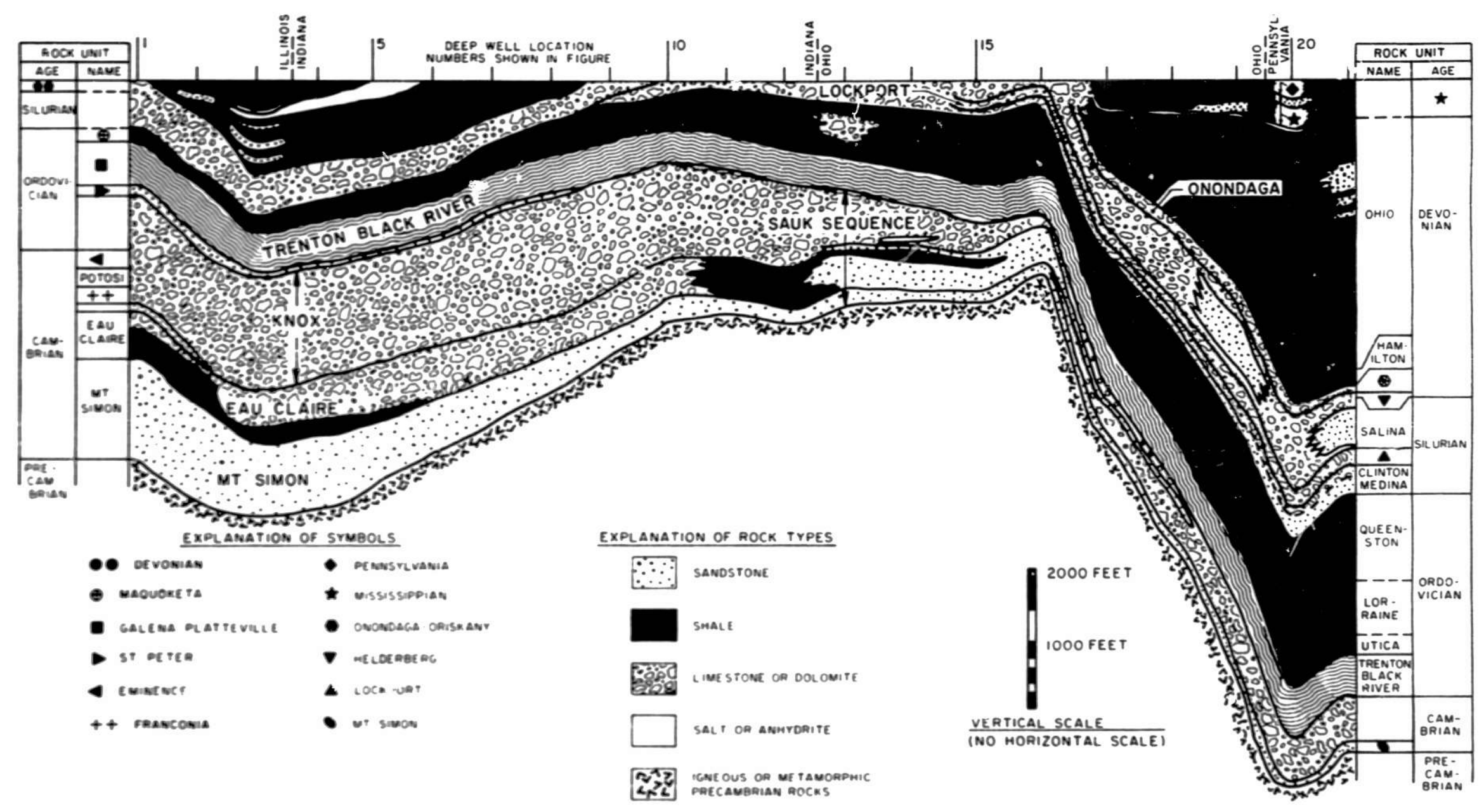

Fig. 7. Example of a Stratigraph Cross-Section (ORSANCO). 


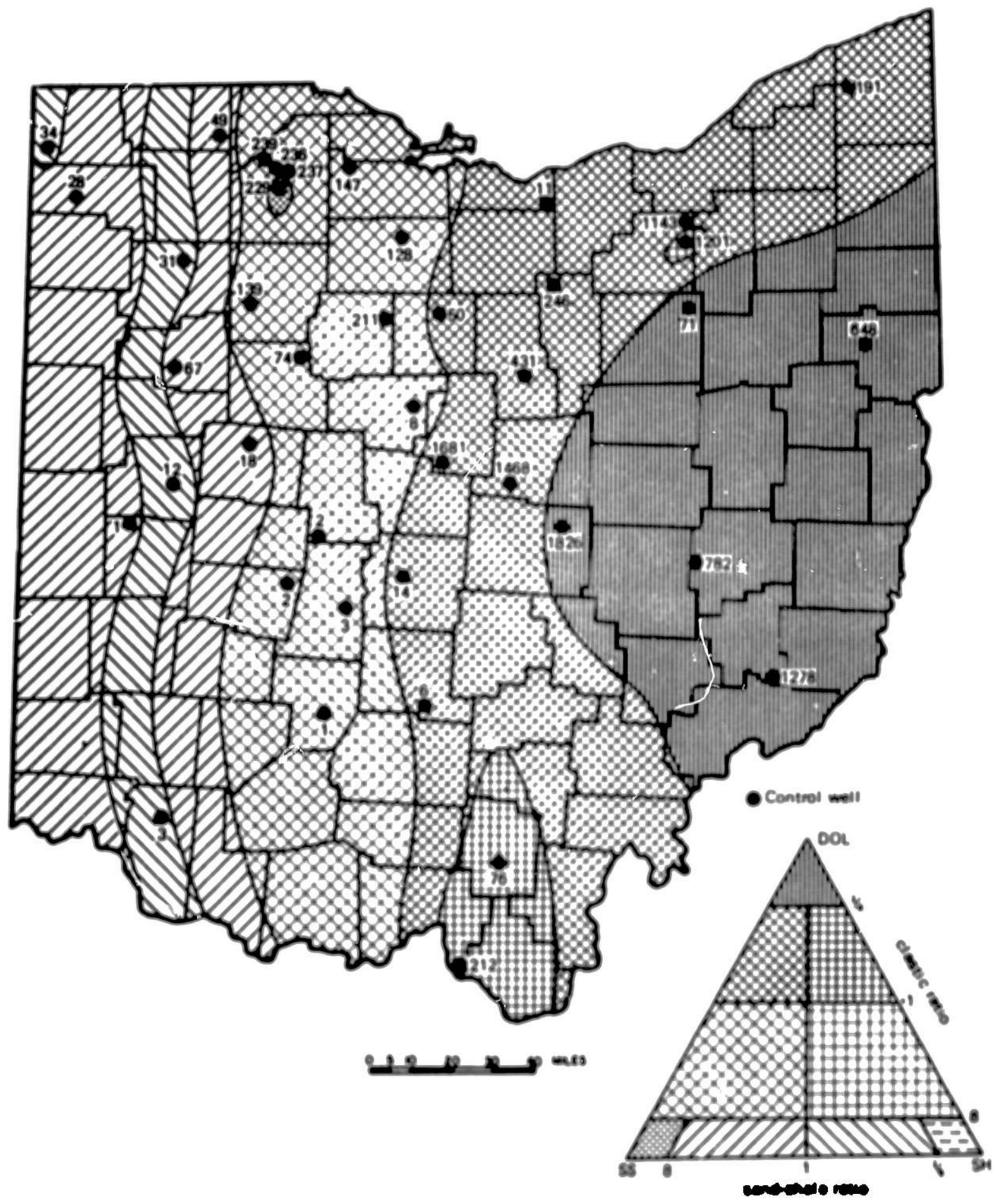

Fie. 8. Example st lifliuluete Ratlo Map: Powt-

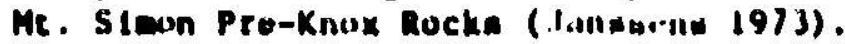




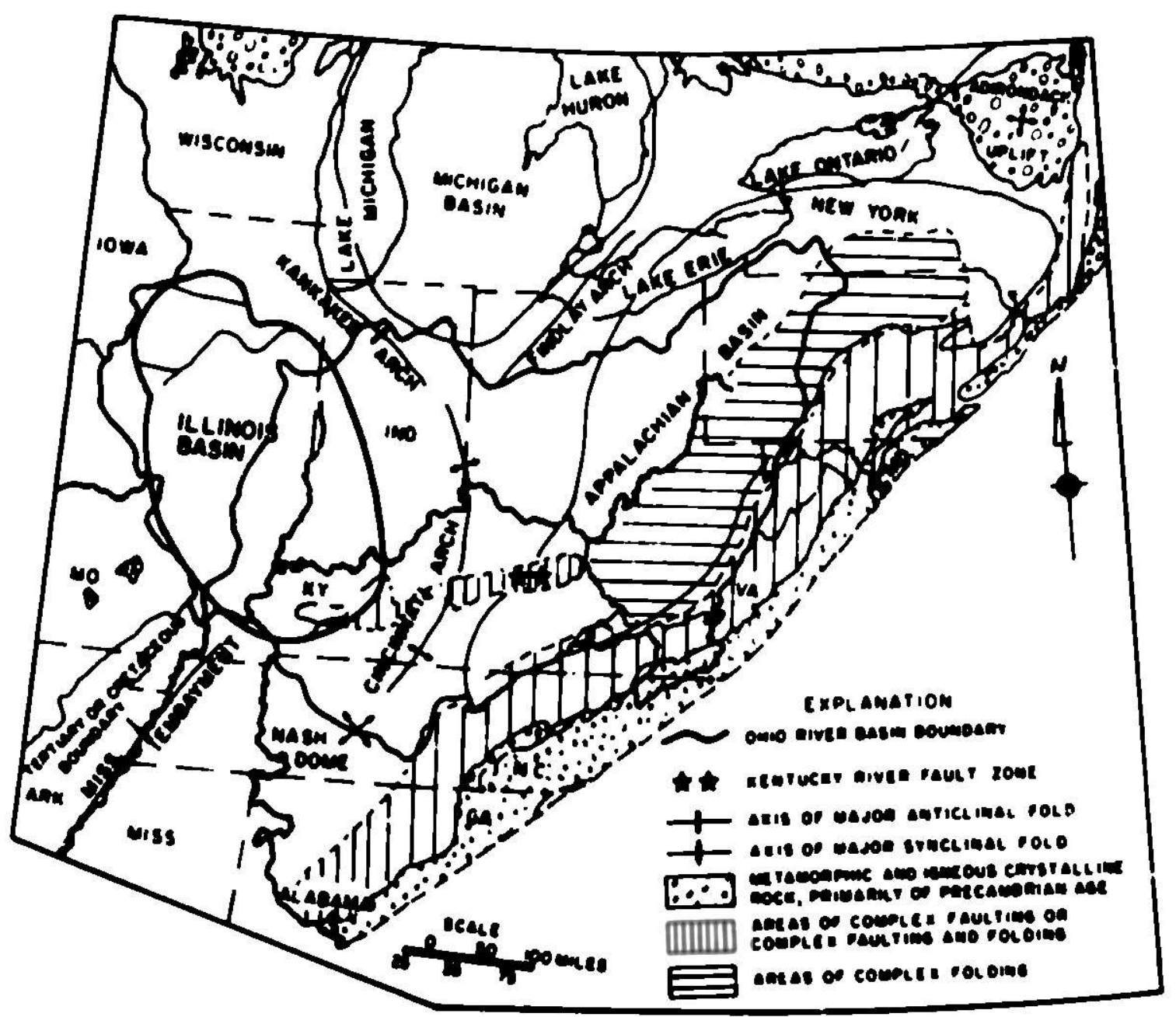

18. 9. Map of the Ohlo River Basin and Vicinity Showing Soev Major Geologic Features. Date Modifled froe Publlahed Maps (ORSANCO).

cryetelline core of the Appelachian Mountains fron the Alabean-Georgla border north Into Caneds. Other areas of reletively Intenee rock defornation are che laulted and Iractured Rouch Cresk. Kentucky River, and ansoclated fault sonea.

seructural seology an also be presented by the etructural contour map. ouch as Fis. 10, a eeructural concour ap Indicating the depth of the top of the Me. sieon Formetion in Illinols. Such a allowe an estieste of the approxtacte depth to the apped unit and showe the location of known faults and folds 


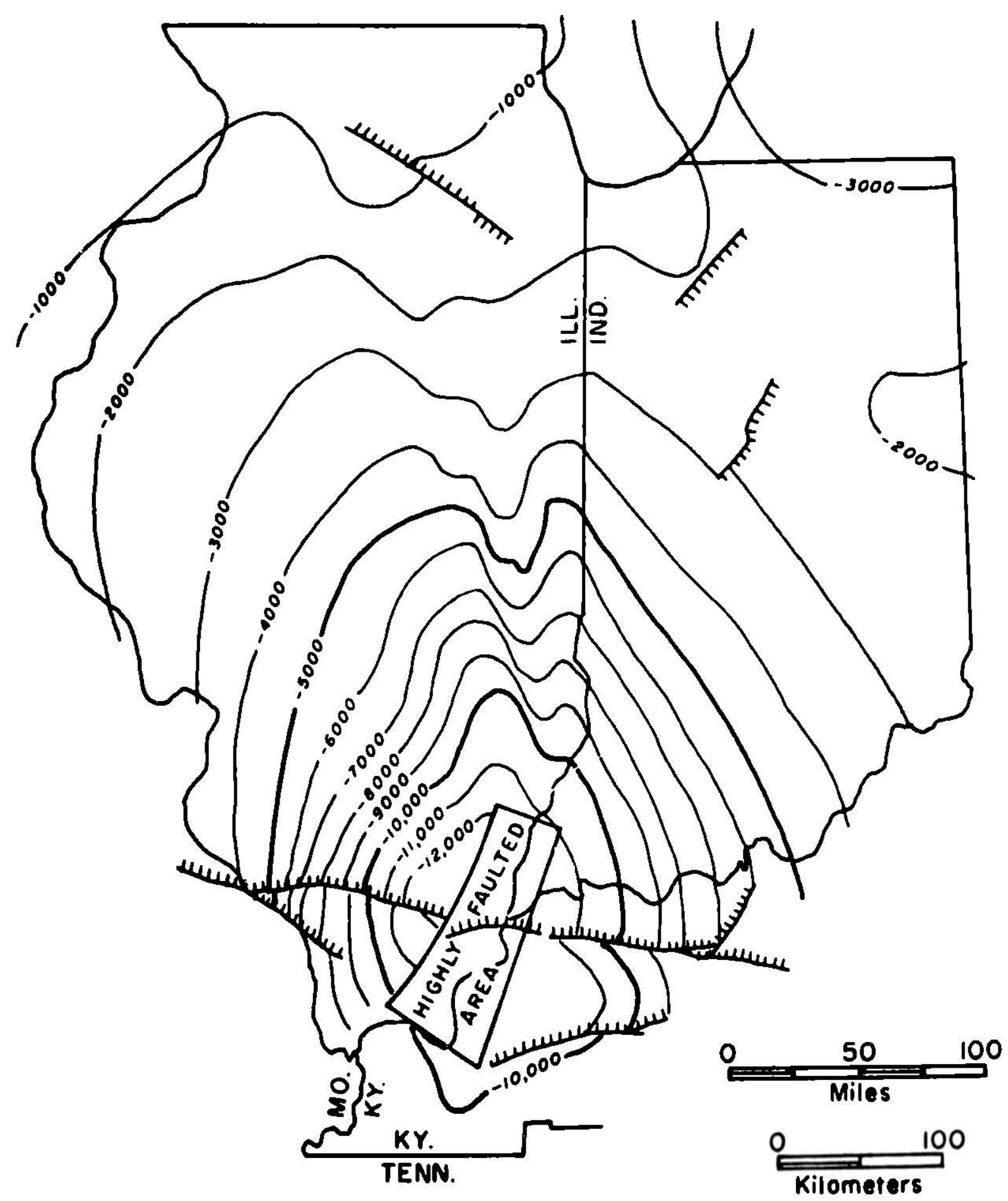

- -5000 Contour, interval $1000 \mathrm{ft}$ Tlmmmo Foult, downthrown side indicoted

F1g. 10. Example of a Structural Contour Map: Top of the Mt. Simon Format ion (Bond 1972). 
that may influence decistons concerning the location and monitoring of an injection well. It would be immediately apparent from Fig. 10 that the Mt. Simon Formation is not a promising injection zone in southeastern Iilinois and southwestern Indiana because $i t$ is at great depth and because that area is highly faulted. A still more detailed structural map is of ten prepared for the immediate vicinity of the injection well.

\section{Lithology}

Lithology (i.e., information on the composition and texture of rocks) may be described briefly and generally for a region, as in Fig. 5. On the other hand, 1ithologic descriptions prepared for individual wells are very detallid. An example of a description of a core from one well at the top of the Mt. Simon formation is shown in Table 5 .

Such detalled descripctons, prepared from cores, cuttings, and geophysical ligs, are necessary for determining local rock characteristics. From such descriptions and other data, injection intervals, confining beds, and casing points are selected.

\section{Subsurface Water}

One criterion for judging whether wastewater should be injected into an aquifer is the chemistry of the aquifer water, partly because of the possibility of reactions with injected waterwater (e.g., those described in II.E.3).

Policy concerning the minimum salinity of water in aquifers approved for wastewater injection varies by state. Groundwaters containing less than $1000 \mathrm{mg} / \mathrm{l}$ of dissolved solids may be expected to be protected except under unusual circumstances. Water containing less than $500 \mathrm{mg} / 1$ is presently considered to be acceptable for potable water to be used by interstate carriers (USPHS 1962). Formerly (USPHS 1946), if such water was not avallable, water containing $1000 \mathrm{ppm}$ of dissolved solids was considered acceptable.

The minimum salinity of an injection zone may be set at a level higher than $1000 \mathrm{mg} / 1$ of dissolved solids to provide a margin of safety. Water with several times this dissolved solids content is now used in some areas and may be more widely used in the future. Illinols agencies, for example, have declded that groundwater contalning less than $10,000 \mathrm{mg} / \mathrm{l}$ should be protected (ORSANCO). According to the New York State classification, on the other hand, water having a total dissolved solids content of $1000 \mathrm{mg} / 1$ or less is considered to be fresh (ORSANCO). Waste injection is prohibited in aquifers contalning water with a dissolved solids content of $2000 \mathrm{mg} / 1$ or less (ORSANCO). In Florida, the limiting value is $1500 \mathrm{mg} / \mathrm{l}$ (Garcla-Bengochea). The approximate depth to aquifers contalning fluid with salt concentrations greater than some limit is depicted by maps such as the map for the ohto Valley and adjacent areas shown in Fig. 11. This map gives a very broad Indication of the depth range to which surface casings must extend in order to close of $f$ aquifers containing potable water. It also shows that in portions of the eastern Ohto Valley there are no saline water-bearing aquifers that can be used for disposal. 
Table 5. Example of Core Description (Core Taken from the Top of the Mt. Simon Formation from a Well in Illinois).

\begin{tabular}{ll}
\hline Footage & \multicolumn{1}{c}{ Description } \\
\hline $3019.4-3020.5$ & $\begin{array}{l}\text { Sandstone; graylsh-white; medium to very coarse grained; } \\
\text { grains are broken, pitted, and chipped; very cohesive } \\
\text { and hard; very tight; semi-quartzitic. }\end{array}$ \\
$3020.5-3021.8$ & $\begin{array}{l}\text { Sandstone; as above; very poor sorting; medium to very } \\
\text { coarse, rounded grains, with abundant fine-grained } \\
\text { matrix; glassy, slightiy pyritic; cohesive and hard; } \\
\text { not as tight as above zone; limited mud invasion. }\end{array}$ \\
$3021.8-3023.8$ & $\begin{array}{l}\text { Sandstone; good sorting; very fine to fine, subangular } \\
\text { grains; slightly pyritic; cohesive and firm; limited } \\
\text { mud Invasion; very few shale laminations. }\end{array}$ \\
\hline
\end{tabular}




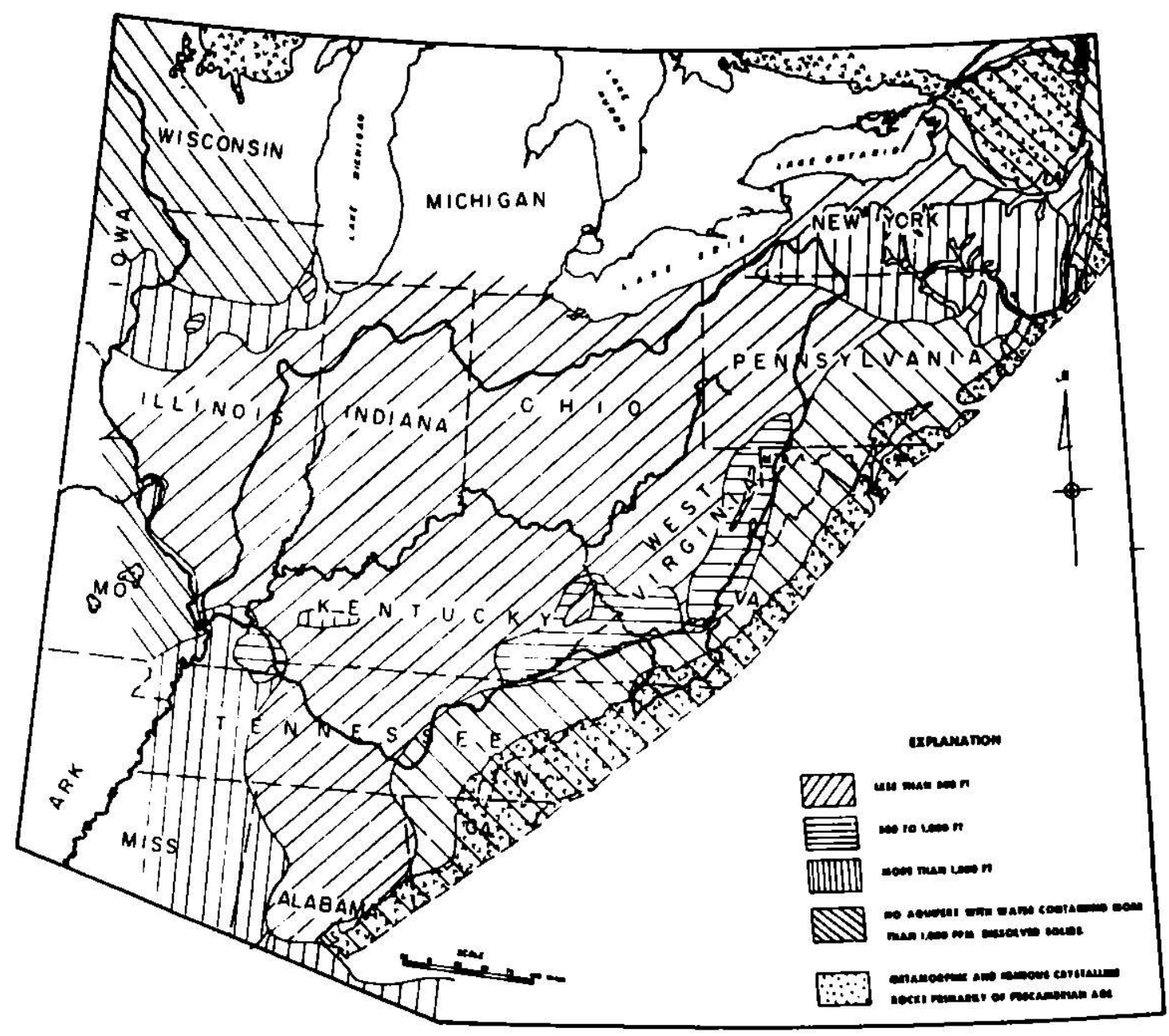

Fig. 11. Example of Map Indicating Depth to Aquifers Containing Dissolved Solids Concentrations Greater than $1,000 \mathrm{mg} / 1$ (ORSANCO). 
In Illinois, the Mt. Simon formation has been found to contain water with dissolved solids concentrations ranging from less than $1000 \mathrm{mg} / 1$ in the northern part of the state to over $300,000 \mathrm{mg} / \mathrm{l}$ in the southern part. Such information can be displaysd in the form of an 1socon map (showing lines connecting points of equal concricratiun) 1llustrated by Figure 12 . Most of the dissolved solid is sodium chloride, but significant amounts of calcium, magnesium, and sulfate are also present (Table 6).

Samples of solids and liquids of a formation are obtalned for detalled analysis during well construction by drill-stem tests and after construction by pumping tests. Geophysical logs are also useful for estimating the dissolved solids content of aquifer water in intervals that are not sampled, as discussed below (III.C.2.).

The viscosity of subsurface water varfes with both temperature and the concentration of dissolved solids; in most areas, both of these parameters increase with depth. Figure 13 shows that the combined effects of these two variables on viscosity tend to be offsetting. In a typical example of a 3000ft-deep-well with a bottom-hole temperature of $100^{\circ} \mathrm{F}$ and formation water with a total dissolved solids content of $120,000 \mathrm{ppm}$, the viscosity of the water would be about 0.85 centipolse as compared with a viscosity of 1.0 centipoise for fresh water at $68^{\circ} \mathrm{F}$. If it were not for 1 ts salinity, the viscosity of the formation water at $100^{\circ} \mathrm{F}$ would be much lower, about 0.7 centipolse fur fresh water.

The density of subsurface water must be taken into account in the equations for subsurface liquid flow, since gravity ts the driving force for regiunal flow and since the greater the itnsity of a column of water, the greater the pressure it can exert. Also, reservnte fluid density is a consideration in predicting wastewater movement. Temperature and pressure have little effect on fluid density in the range in which they occur in wastewater infection. For example, for fresh water at a reservoir temperature of $200^{\circ} \mathrm{F}$ (inhich might be encountered at a depth of $10,000 \mathrm{ft}$ ), the density would be 0.965 as compared with 1.0 at $60^{\circ} \mathrm{F}$. Pressure has a simllar effect but in the opposite dirertion, so that the two variables are nearly of fetting. A potentially more Iriportant influence on the density of water in subsurface reservoirs is the total dissolved solids content. Figure 14 shows the relationship between di:soolved solida concentration and the relative density in deep aquifers In the Illinols basin. From the figure, it can be seen that density increases as large as 15 percent have been observed in very saline formation waters.

During infection, the total fluid pressure in the subsurface reservoir Is the sum of the natural reservolr pressure and the pressure which must be added to emplace the desired amount of wastewater. Since the total pressure may be the constraining limit on the injection rate, the original reservolr pressure must be known.

Fluid pressure can be measured directly in the borehole at the depth of the injection horizon, usually by performing a drill-stem test, which is described below. Fluid pressure at the injection horizon can also be measured Indirectly by determining the static water level in the borehole, then computing the pressure of the fluid coiumn at the depth of interest. 


\section{1}

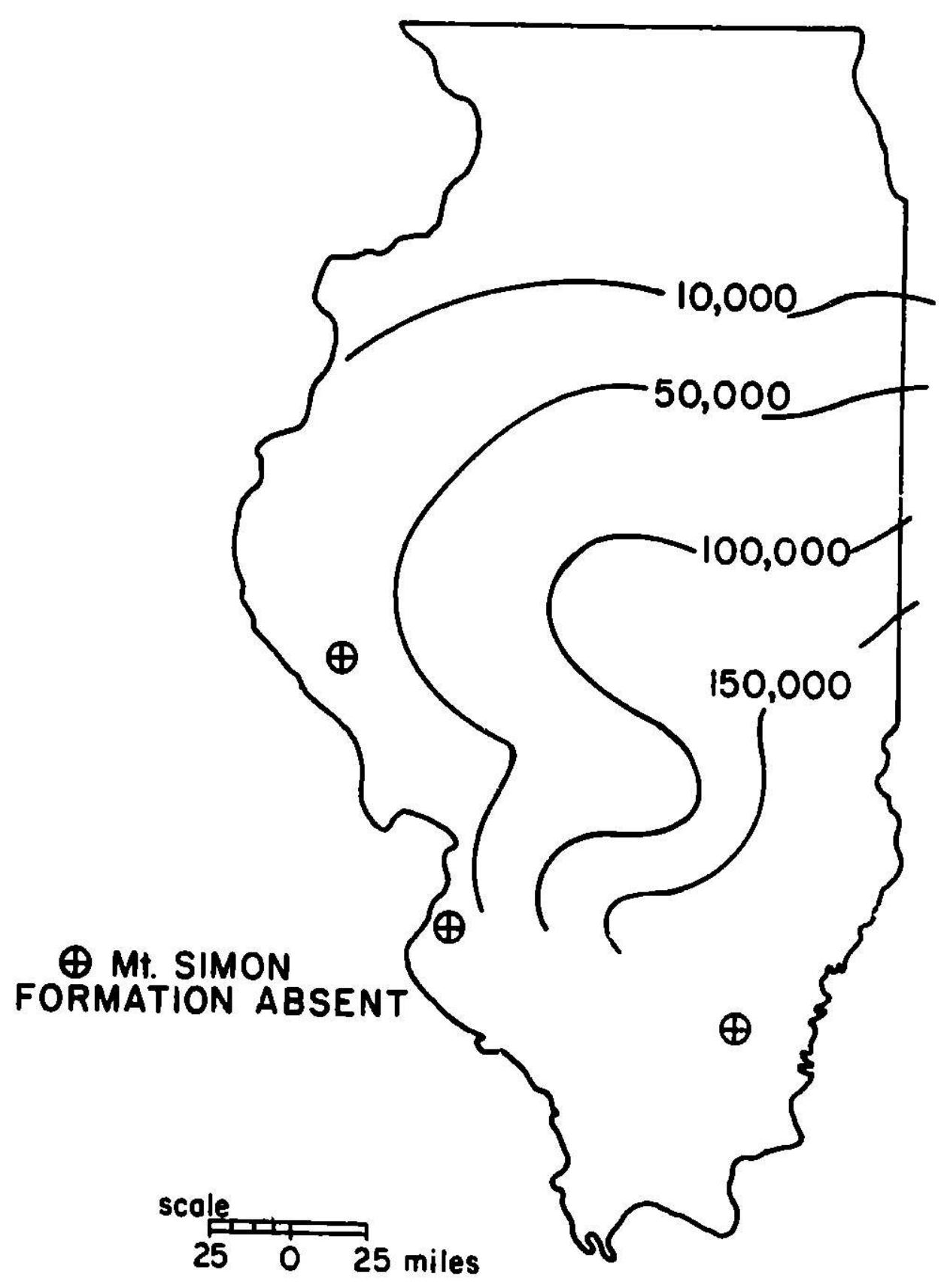

F1g. 12. Example of Isocon Map, Show!ng the Dissolved Solids Content (In parts per million Parts of Water) in the Upper 100 feet of the Mt. Simon Formation in Illinois 
Table 6. Example of Composition of Native Aquifer Fluids; Analysis of Water from the Mt. Simon Formation in the Vicinity of Bloomington, Illinols

\begin{tabular}{lcc}
\hline \multicolumn{1}{c}{ Analysis } & Results \\
\hline Specific Gravity & 1.050 \\
$\mathrm{pH}$ & 6.6 & \\
Hydrogen Sulfide & 0.0 & $\mathrm{mg} / 1$ \\
Carbonate Alkalinity & 0.0 & $\mathrm{mg} / 1$ \\
Bicarbonate Alkalinity & 68 & $\mathrm{mg} / 1$ \\
Chlorides & 39,250 & $\mathrm{mg} / 1$ \\
Total Hardness & 17,900 & $\mathrm{mg} / 1$ \\
Calcium & 5,200 & $\mathrm{mg} / 1$ \\
Magnesium & 1,190 & $\mathrm{mg} / 1$ \\
Sulfates & 1,700 & $\mathrm{mg} / \mathrm{j}$ \\
Manganese & 1.3 & $\mathrm{mg} / 1$ \\
Total Iron & 27.0 & $\mathrm{mg} / 1$ \\
Total Dissolved Solids & 65,460 & $\mathrm{mg} / 1$ \\
$\quad$ (Calculated) & & \\
\hline
\end{tabular}




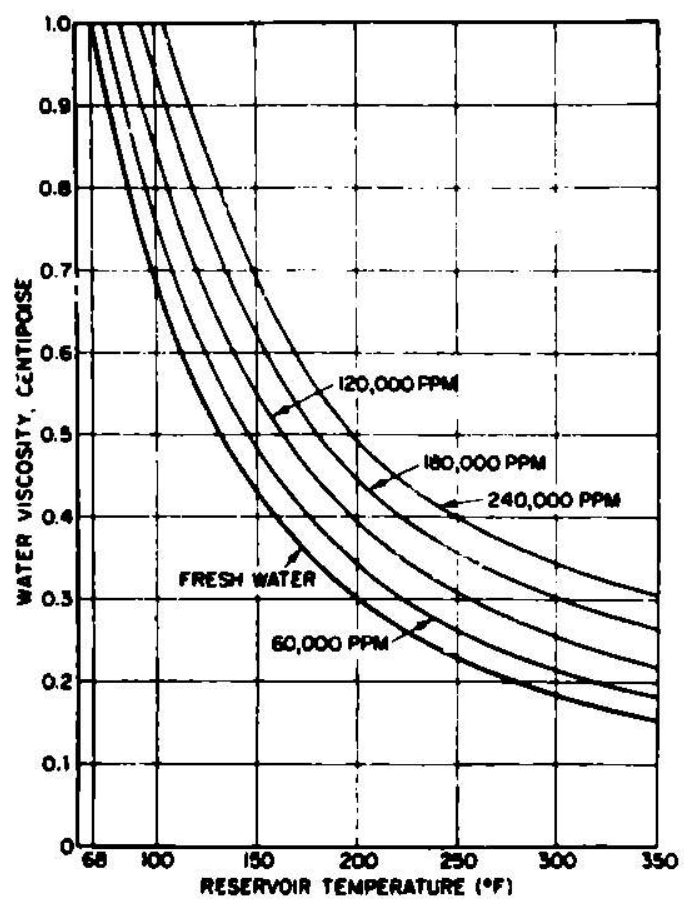

F1g. 13. Viscosity of Subsurface Water as a Function of Reservolr Temperature and Total Dissolved Solids Content (PIrson).

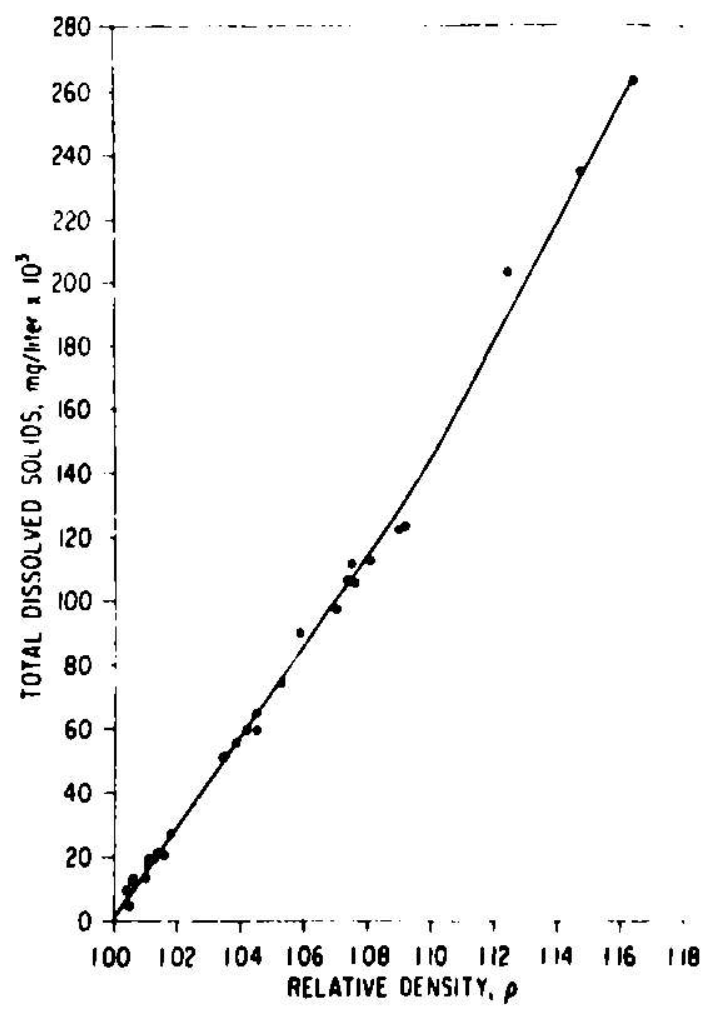

F1g. 14. Relation Between Relative Density and Dissolved-Solids Content of Brines in Deep Aquifers of the Illinols Basin (Bond 1972). 
A column of water $1 \mathrm{ft}$ deep with a specific gravity of 1.0 exerts a pressure of $0.433 \mathrm{ps} 1$. A 10-ft-deep column, would exert a pressure of 4.33 ps1. When the average specific gravity of the water is other than 1.0 , the rate of pressure increase varies accordingly. For example, if a wellbore is filled with formation water having a dissolved solids content of $65,000 \mathrm{mg} / 1$ (as in the example in Table 6) and a spectfic gravity of 1.05 , the fluid pressure would increase at a rate of $0.455 \mathrm{psi} / \mathrm{ft}$; at the bottom of a 1000foot-deep, fluld-filled well, the pressure would be $455 \mathrm{psi}$.

Although instances of truly anomalous formation pressure are likely to be relatively rare at sites selected for wastewater injection, the existence of unusually high or low pressures and the possible reasons for their existence should be recognized. Some causes of anomalous pressure are:

1. Compaction of Sediments

2. Tectonic forces

3. Thermal efferts

4. Osmotic ef fects

5. Massive extraction or injection of fluids

Abnormally high pressures can result from causes $1,2,3$, and 4 , and from massive injection. Abnormally low pressures can result from osmotic effects and extraction of flulds. Abnormally high pressures resulting from compaction of sediments are common in deep wells of the Gulf Coast (Dickinson). Moreover, it has been suggested (Katz 1962) that the abnormally high pressure of these Gulf Coast aquifers is evidence that they are unusually well sealed by surrounding shale iquicludis. Further, they are supposed to have been disconnected, by faults, from the comon, normal-pressure aquifers which have surface outcrops, and therefore would not provide paths for migration to the surface of liquid wastes emplaced in them. From these considerations, 1t was recomrended (Katz 1962) that such aquifers would have advantages over normalpressure aquifers; brief suggestions on procedures for using such aquifers were given. Berry (1973) has concluded that abnormally high pressures in the California coast ranges are a result of tectonic forces. Natural osmotic ef fects and their relation to subsurface wastewater infection have been examined (Hanshaw). Abnormal formation pressure in the Gulf Coast area has been attributed to temperature change (Bradley).

The compressibillty of subsurface water and its importance to aquifer storige capacity, discussed in later sections of this report, must be considered in terms of the general definition of compressibility of an elastic med ium:

$$
B=\frac{-\partial v}{v \partial p} \quad\left[F / L^{2}\right]^{-1 *}
$$

where $B$ - compressibility of medium in units of pressure ${ }^{-1}$

V - Voludi.

l. pressure

The compressibtlity of water varles with both temperacure and pressure, is Is shown in Fig. 15. For problems in wastewater infection, $\beta$ will generally 


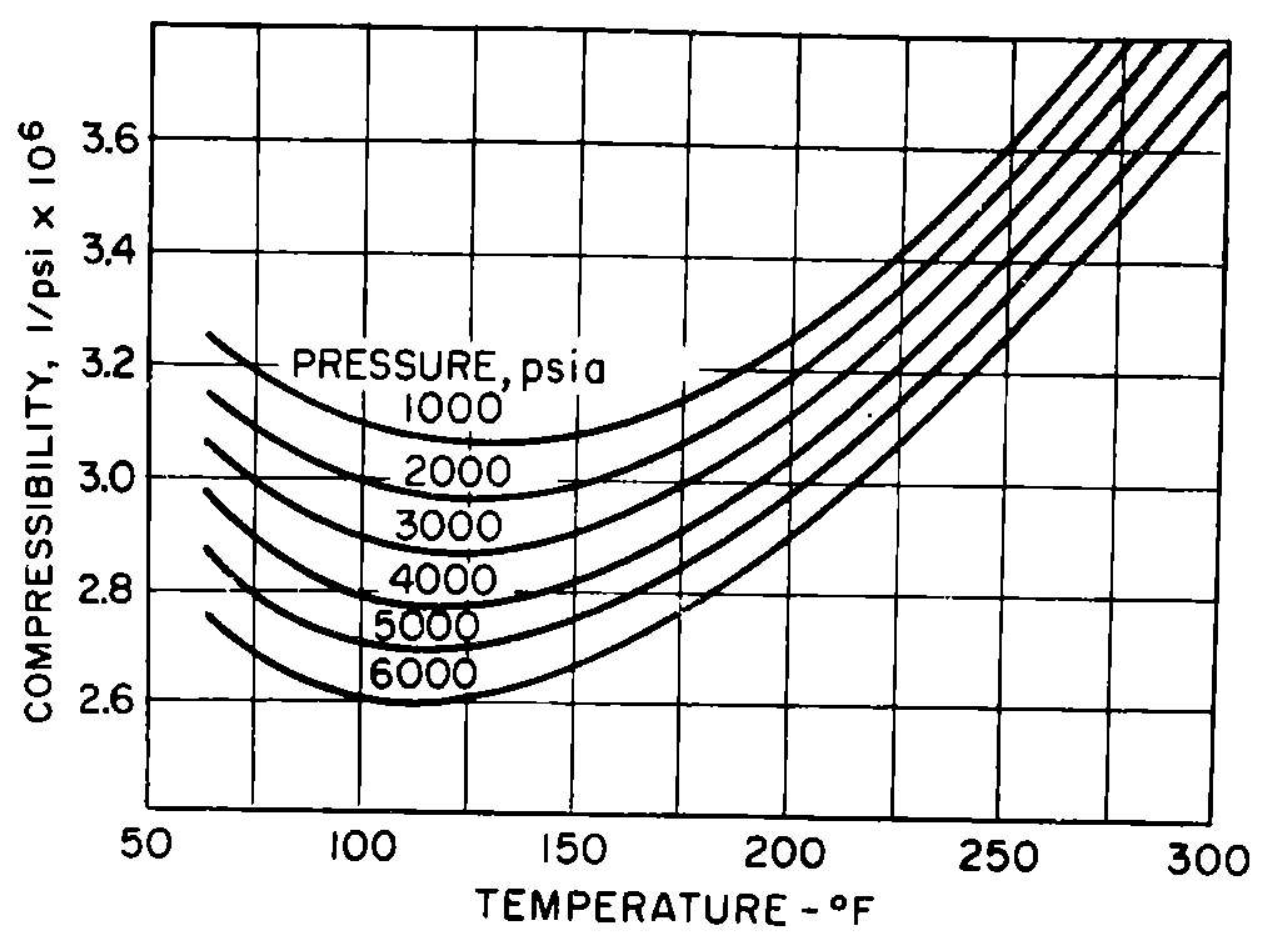

Fig. 15. Variation in the Compressibility of Water with Temperature and Pressure (Katz 1968).

be within the range of $2.8 \times 10^{-6}$ to $3.3 \times 10^{-6} \mathrm{psi}^{-1} ; 3.0 \times 10^{-6} \mathrm{psi}^{-1}$ is a reasonable value to assume in most cases at usual temperatures and pressures.

\section{Mechanical Properties of Injection and Confining Units}

The porosity of an aquifer and importance of porosity to the capacity for storing waste fluids should be considered in terms of the general definition of total porosity:

$$
\phi=\frac{V_{\mathrm{v}}}{V_{\mathrm{t}}} \quad \text { [dimensionless] }
$$

where $\phi=$ porosity, expressed as a decimal fraction or as a percentage

$v_{v}=$ volume of volds in rock sample

$v_{t}=$ total volume of rock sample

Porosity has been classifled as primary or secondary. Primary poros1ty includes original intergranular or intercrystalline pores and the porosity associated with fossils and bedding planes. Secondary porosity results from fractures, solution channels, and recrystallization and dolomitization. Intergranular porosity, occurring principaliy in unconsolidated sands and in sandstones, can be measured reasonably well in the laboratory, using core samples taken from wells. Porosity contributed by fractures and solution channels is difficult to measure in the laboratory. Varlous borehole geophysical methods that are discussed below (III.C.2) can be used to determine the porosity of strata in place. Porosity in reservolr formations xanges from a maximum of about 0.40 in unconsolidated sands to as 11 ttle as 0.02 in dense limestones. The distribution of porosity over a region may be fudzed from maps of the 
type illustrated in Fig. 16, showing the average porosity of the Mt. Simon formation in Illinols, which ranges from about $2 \%$ to $16 \%$.

The permeability of an aquifer indicates its capability to transmft fluid. Permeability is quantifled by the coefficient of permeability or hydraulic conductivity. When the properties of both the fluid and the porous medium are considered, the coefficient of permeability, $\bar{k}$, is defined by Darcy's law as:

$$
\overline{\mathrm{x}}=\frac{\mathrm{Q} \mu}{\mathrm{A} \rho \mathrm{g}} \frac{\mathrm{dL}}{\mathrm{dh}}, \quad\left[\mathrm{L}^{2}\right]
$$

where, in cgs units,

$$
\begin{aligned}
& Q=\text { flow rate through porous medium, } \mathrm{cm}^{3} \mathrm{sec}^{-1} \\
& A=\text { cross sectional area through which flow occurs, } \mathrm{cm}^{2} \\
& \mu=\text { fluld viscosity, } \mathrm{g} \mathrm{cm} \mathrm{cm}^{-1} \mathrm{sec}^{-1} \\
& \rho=\text { fluid density, } \mathrm{g} \mathrm{cm}^{-3} \\
& \mathrm{~L}=\text { length of porous medium through which flow occurs, cm } \\
& \mathrm{h}=\text { fluid head loss along } \mathrm{L}, \mathrm{cm} \\
& \mathrm{g}=\text { acceleration of gravity, cm sec-2 }
\end{aligned}
$$

If cgs units are used, the coefficlent of permeability from Equation 3 will be expressed in $\mathrm{cm}^{2}$. The unit of permeability used in oil field work is the darcy, which is defined by:

$$
\overline{\mathrm{K}}=\frac{\mathrm{Q} \mu}{\mathrm{A}} \cdot \frac{\mathrm{dL}}{\mathrm{dp}}, \quad\left[\mathrm{L}^{2}\right]
$$

where $p=\rho g h=$ pressure,

and

$$
1 \text { darcy }=\frac{1 \mathrm{~cm}^{3} / \mathrm{sec} \times 1 \text { centipolse } \times 1 \mathrm{~cm}}{1 \mathrm{~cm}^{2} \times 1 \text { atmosphere }}
$$

A st1ll simpler form of Darcy's law is used in groundwater studies which the density and viscosity of water do not vary greatly.

$$
K=\frac{Q}{A} \frac{d L}{d h} \quad[L / T]
$$

The constant $K$ is referred to as the hydraulic conductivity and is usually expressed in $\mathrm{cm} / \mathrm{sec}$ or in U.S. Geologic Survey units, which are gallons/(day $\left.x \mathrm{ft}^{2}\right)$ (melnzers). A table for conversion of permeability units is given in Appendix B.

Permeability values for the formations used for wastewater injection range generally from several darcies to less than a inflidarcy (one millidarcy. $10^{-3}$ darcy). Average permeability values for the Mt. Simon formation in Illinois range from more than 100 millidarcies in the north to less than 1 millidarcy in the south. The permeability of shale beds in the Eau Claire formation, overlying the Mt. Simon formation, is consistently less than 0.001 millidarcy. 


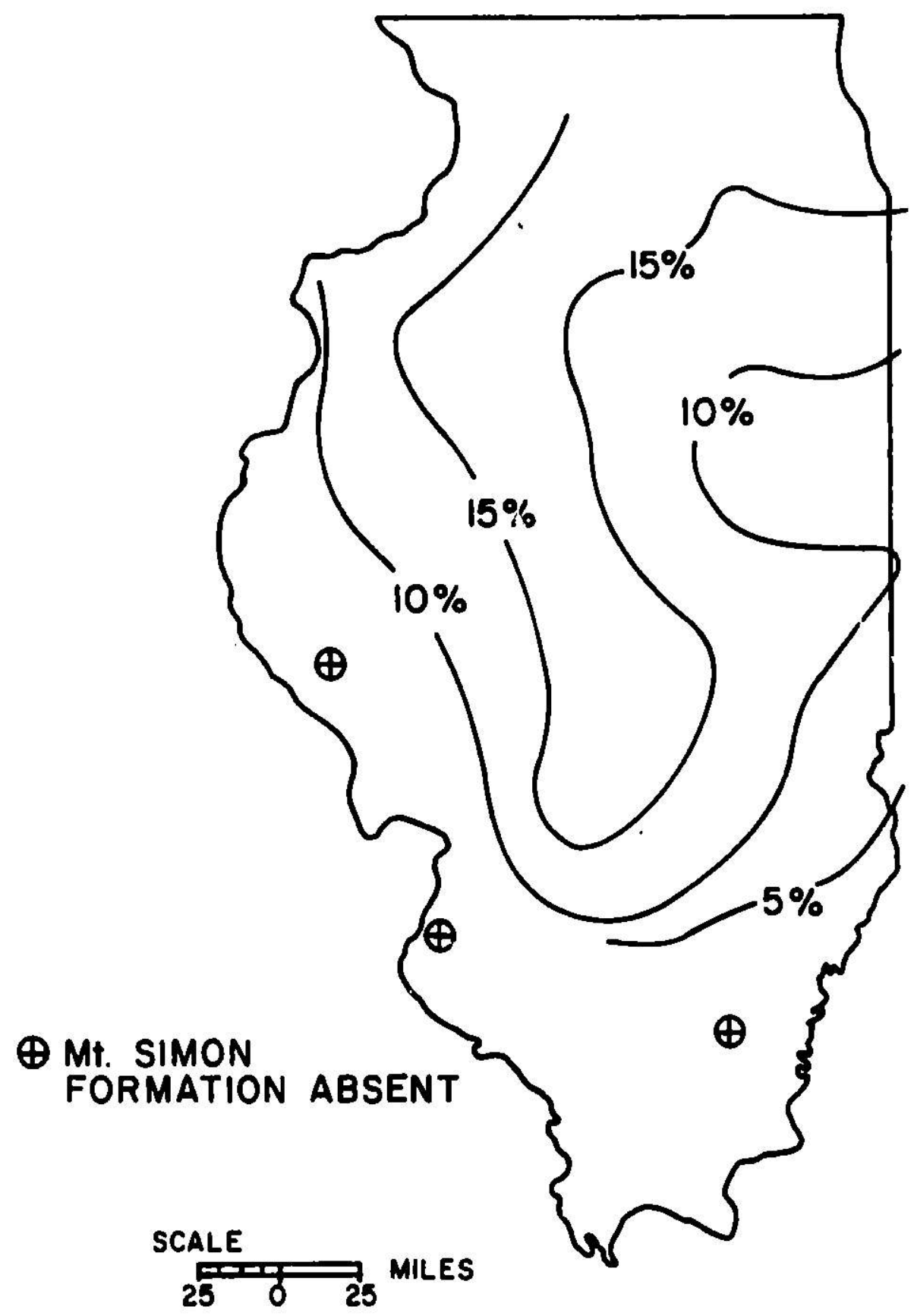

F1g. 16. Example of Porosity Distribution: Average Porosity of the Mt. Simon Formation in Illinols 
A useful constant in hydrogeologic work is the coefiticlent of transmissivity (transmissibility) which is the permeabllity or hydraulic conductivity multiplied by the thickness of the aquifer. When the unit of permeability is the darcy, transmissivity is in darcy-ft/centipolse.

The compressibility of an aquifer includes both the compressibillty of the aquifer akelton and that of the contained fluids. Thus, the total ccopressibility of an aquifer is

$$
C=\$ B+a \quad\left[F / L^{2}\right]^{-1}
$$

where $C=$ compressibility of aquifer, In units of pressure-1

- porosity

$B$ - compressibility of water

a - compressibility of aquifer skeleton

The compressibility of water is discussed above (III.B.4). The compressibility of aquifer skeletons varies gi zatly, from as little as $1 \times 10^{-8} \mathrm{psi}^{-1}$ in consolidated rocks to as much as $1 \times 10^{-5} \mathrm{psi}^{-1}$ in unconsolidated materials.

The coefficlent used in the analysis of reservolr response to injection or pumping is the storage coefficient (storativity), which is defined by:

$$
S=\operatorname{arb}\left(\beta+\frac{a}{b}\right) \quad \text { [dimensionless] }
$$

where $B$, and a are as previously defined, and

$S$ - otorage coeffictent

$Y=\rho g=$ opecific welght of water per unit of surface area

b = aquifer thickness

The atorage coefficlent is the volume of water an aquifer releases or takes into storage per unit surface area per unit change in hydraulic head. The storage coefficlent may be eatimated frow Equation 7, or may be deterwined from aquifer tests that are described below (III.C.2). Values of $S$ are reported to range from $5 \times 10^{-5}$ to $5 \times 10^{-3}$ for confined aquifers. In eatiating the value of $S$ for the Mt. Sinon formation In northern Illinols it may be assumed that - 11\%, b- $1700 \mathrm{ft}, y=0.45 \mathrm{pel} / \mathrm{ft}, \mathrm{B}=3.0 \times 10^{-6} \mathrm{pe1}-1$, and a $-6.7 \times$ $10^{-6} \mathrm{ps} 1^{-1}$. Then, frod Equation $7, \mathrm{~S}=5.4 \times 10^{-3}$. This ie a high value explained by the aquifer being very thick. If the coapreseion of the vater alone were considered, S would be $2.5 \times 10^{-4}$. The Illinois State Hater Survey estiated an average storage coefficlent of $1 \times 10^{-4}$ for the Mt. Simon formation In northern Illinols (IWS), which is probably too low an estinnte if the entire thickness of the formation is taken Into consideration.

The cenperature of the aquifer and Ite combined fluids lo important because telaperature affects fluld propertles. The temperature of shallow groundwater 10 generally about 2 to $3^{\circ} \mathrm{F}$ h1gher than the mean annual air teaperature. Below

\footnotetext{
Testing of the Mt. Sicon formation (In a gas etorage field in northern Illinoig) yielded a value of coapressibility of the formation and 1te contalned water of about $7 \times 10^{-6} \mathrm{peI}-1$. Since the vacer only occuples $11 x$ of the rock, the rock skeleton coupreanibillty at the location $106.7 \times 10^{-6} \mathrm{pet}^{-1}$.
} 
30 to $60 \mathrm{ft}$, the temperature increases approximately 1 to $2^{\circ} \mathrm{F}$ per $100 \mathrm{ft}$ of depth. Geothermal gradient maps for the United States have been prepared by and are available from the American Assoctation of Petroleum Geologists, Tulsa, Oklahoma. Figure 17, a modification of one of the AAPG maps, shows geothermal gradients in Illinols and Indiana. The measured temperature at a depth of 3000 feet near Pontiac, Illinols was $90^{\circ} \mathrm{F}$.

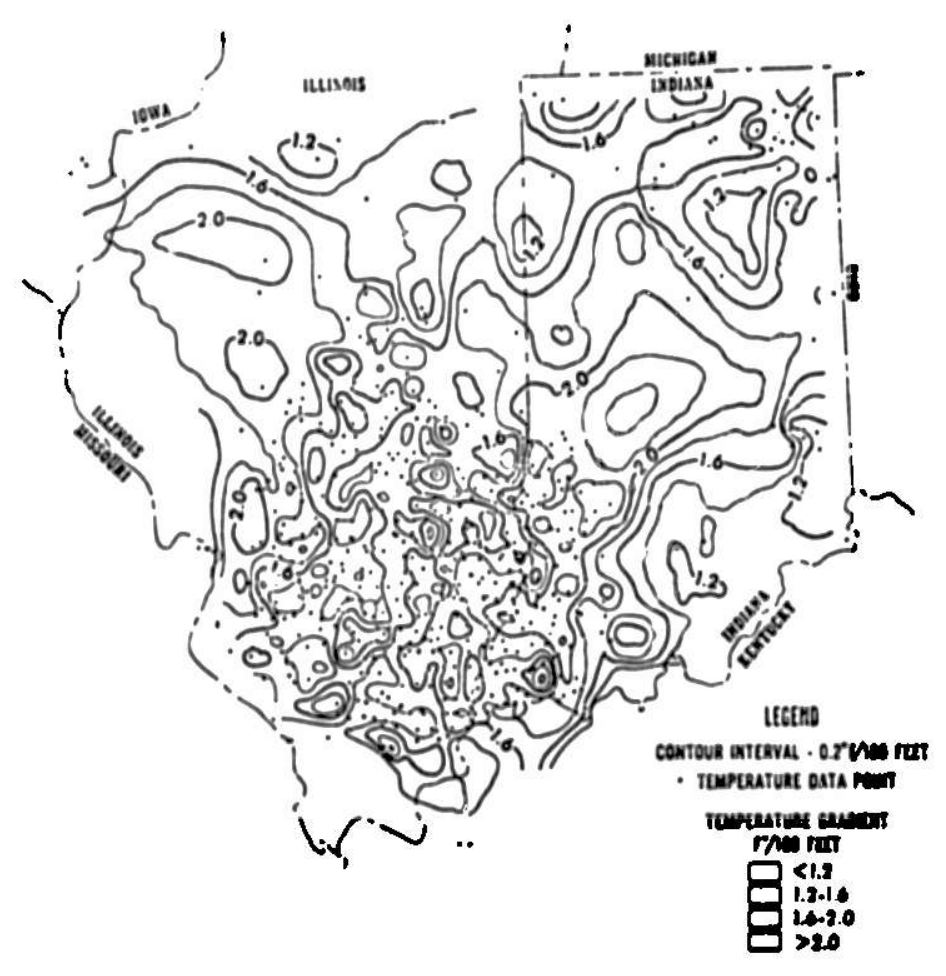

1:18. 17. Example of Mapping of Geothermal Gradients Adopted from Portfollo Map No. 10, from the American Association of Petroleum Geologists Geothermal Survey of North America.

Hydraulic fracturing, generally weaning the introduction of fractures through the pressure exerted by injected water. Is an important consideration in choosing the operating conditions for waste infection. Hydraulic fracturing has been used in crude oll production to increase the permeabllity of underground formations, and thereby the rate of production. However, in disposal of wastes lintended to remain in liquid form (not in the form of a grout; see Appendix A), under some clrcumstances it could introduce paths for potential escape of the waste from the intended storage aquifer. Thus, hydraulic fracturing should bo carefully used in the disposal of liquid wases, and it may be prohibited in local legal regulations of deep-well infection of liquid wastes.

In order to predict the pressure at which hydraulic fracturing or fault movement would be expected to occur, It 18 necessary to estimate the atate of stress at the depth of the infection horizon. On the other hand, determination of the actual fracture pressure allows computation of the state of atress (Kehle). 
The general equation for total normal stress across a plane in a porous medium is :

$$
S_{t}=p_{0}+\sigma_{1} \quad\left[F / L^{2}\right]
$$

where $S_{t}=$ total stress

$p_{0}^{t}=$ fluid pressure

$\sigma_{1}^{0}=$ effective or intergranular normal stress

Effectlve stress, as defined by Equation 8, is (1) the stress available to resist hydraulic fracturing or (2) the stress across a fault plane that acts to prevent movement on that fault. The equation shows that, if total stress remains constant, an increase in fluid pressure reduces the effective stress and a decrease in fluid pressure increases effectlve stress. When the effective stress is reduced to zero by fluid injection, hydraulic fracturing occurs. Fault movement occurs before the normal stresses across the fault plane are reduced to zero, since there must be some shear stress acting on the fault blocks to cause them to move.

In a sedimentary rock sequence, the total normal vertical stress increases with depth of burial under rock and fluid. It is commonly assumed (and the validity of the assumption can easily be verified) that that normal vertical stress increases at an average rate of about $1 \mathrm{psi} / \mathrm{ft}$ of depth. The lateral stresses may be greater or less than the vertical stress, depending on geologic conditions. In areas where crustal rocks are being actively compressed, lateral stresses may exceed vertical stresses. In areas where crustal rocks are not in active compression, lateral stresses are expected to be less than the vertical stress. Lateral stress may be estimated prior to drilling of a well on the basis of hydraulic fracturing data from nearby wells and/or knowledge of the tectonic state of the region where the well is located. The tectonic state of various regions is only now belng determined. For example, it was concluded (Kehle) from hydraulic fracturing data taken from four wells, that the stresses at the well locations in 0klahoma and Texas were representative of an area that was tectonically in a relaxed state. In contrast, Sbar and Sykes (1973) characterfzed much of the eastern and northcentral United States as being in a state of active tectonic compression. Further discussion concerning the state of stress and hydraulic fracturing is presented in Section III.D. 4 on hydraulic fracturing.

\section{Hydrodynamics}

Hydrodynamics, as the tern has been adopted for use in subsurface hydrology, refers to the potential for flow of subsurface fluids, particularly in deep sedimentary basins. Examples of its application are recent publications (Bond 1972, Clifford 1973) discussing the flow potential in deep aquifers of Illinols, Indiana, and Ohio as determined from pressure, water levels, and water density measurements made in deep wells.

The potential for flow in deep aquifers that are used for wastewater infection is important, hecause it can be used to estimate natural groundwater flow rates and directions. Figure 18 is a map showing the potentiometric surface of the Mt. Simon formation in Ohto and Indiana. The arrows indicate the 


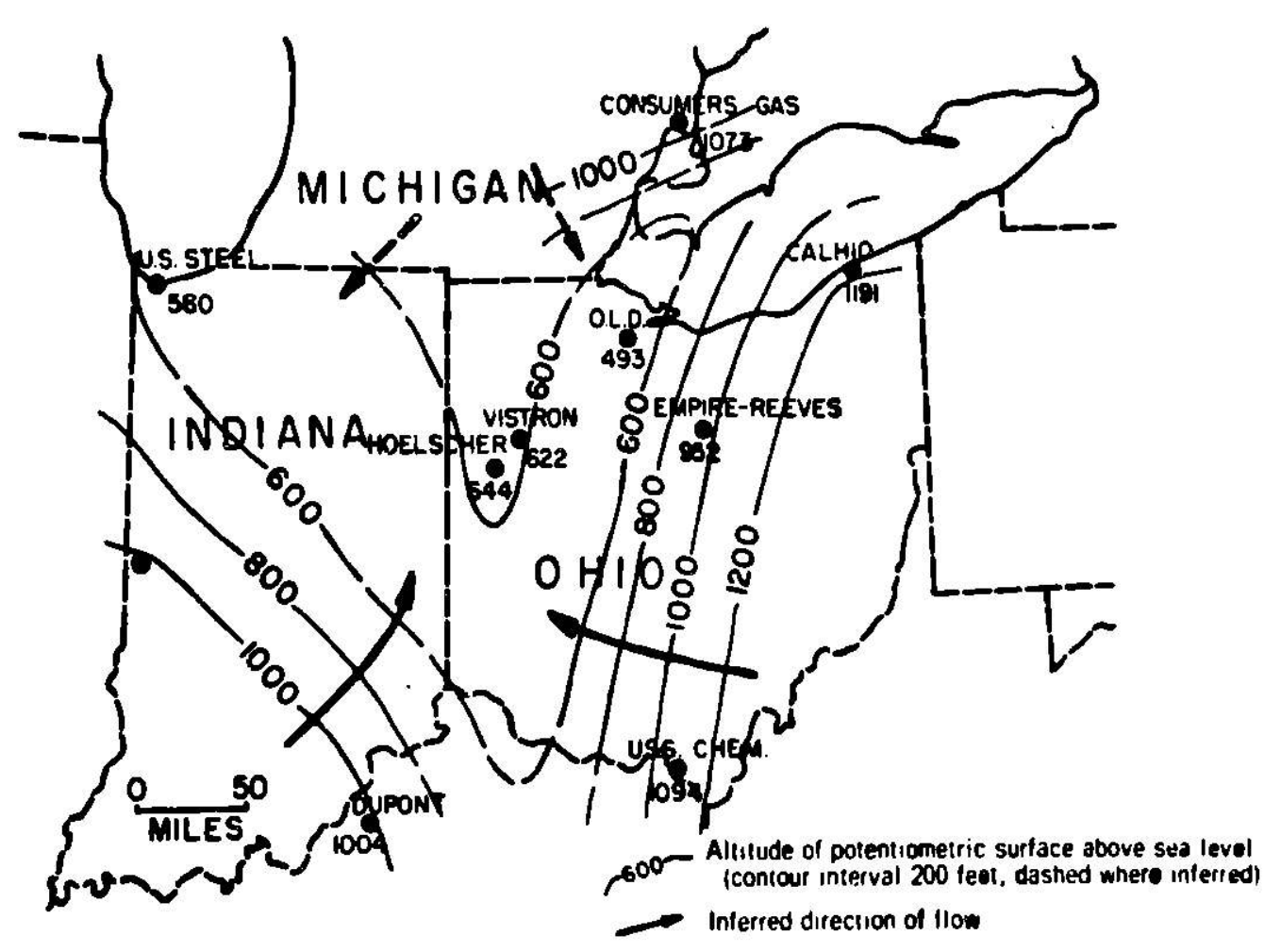

Fig. 18. Example of Map Illustrating Potentials for Flow of Subsurface Fluids. Potentiometric Surface Map for the Mt. Simon Formation in Ohio and Indiana (Clifford 1973).

inferred directions of regional groundwater flow in the Mt. Simon formation as indicated by the potentiometric contours. Bond (1972 and 1973) discusses some of the difficulties in interpretation and application of potentiometric data.

\section{Subsurface Resources}

The occurrence of ofl, gas, coal, mineralized brines, and occasionally other less abundant minerals requires consideration when evaluating the potential of a site for a waste-disposal well. Of the mineral resources, ofl and gas most frequently require consideration because of their wide geographic distribution and because rock units that contain them are of ten physically wellsuited for waste injection. Also, units suitable for waste injection are favorable for storage of natural gas, which is extensively practiced in the northcentral states.

The presence of oil and gas resources in the immediate vicinity of an injection well site does not secessarily preclude wastewater injection, but may limit it. The limitations might be a result of the desire to protect the developed or undeveloped resources and the added difficulty of assuring confinement because each oil or gas well provides an additional posstble pathway for escape of wastewater or saline formation water.

In the review of the occurrence of subsurface resources, the locations, construction, use, and ownership should be determined for all wells (both 
shallow and deep) within the area of influence of the injection well. The plugging records (normally maintained by state agencies) for all abandoned deep wells should be obtained to verify the adequacy of plugging. In states where oil has been produced for many years, there are often areas where wells are known to have been drilled but for which no records are available. There are also wells whose location is known but for which plugging records are not available or plugging is known to have been inadequate. Documenting the status of deep wells near the injection well may be the most important step in monitoring of injection wells in areas that are or have been active oil or gas provinces, because such wells provide the greatest hazard for escape of wastewater or formation water from otherwise well-confined aquifers.

\section{Aquisition of Subsurface Data}

\section{Prior to Drilling}

In the estimation of the performance of injection wells and the evaluation of the subsurface environment prior to construction, the types of information on the subsurface environment described in Section III.B. are estimated from sources such as the flgures and tables presented as examples in that section. The information in those figures and tables has, of course, come from previously drilled wells; if this type of information has not been compiled and formed Into maps, cross sections, and tables, these types of correlation may be necessary before it can be used. Basic data for previously drilled wells is available in most states through state geological surveys, oil and gas agencies, and water resources agencies. In addition, private companies acquire and sell well logs, and other subsurface data. In some cases, it may be necessary to go to individual oil companies or consultants for s ssurface data that are not publicly avaflable.

\section{During Well Construction and Testing}

Most deep wells are todiy drilled by rotary drilling rigs. Rotary drilling rigs use two basic types of drilling bits--rock bits and core bits. Rock bits grind the strata into small ships. The chips are periodically collected, usually after each five or ten feet of new hole, washed, and examined with a low-powered binocular microscope. The methods for collection, examination, and description of such samples have been described (Haun). Soft, unconsolidated clays do not yleld chips, but break down into mud; unconsolidated or soft sandstones break down into Individual grains when drilled. These types of samples are of only limited value in such areas.

Cores taken with rotary core bits and barreis give a much more accurate picture of the subsurface formations than do cuttings, but core samples are very expensive $(>\$ 50 / f t)$ in deep wells and can usually only be afforded in limited numbers. In deep wells, core samples are commonly about $4 \mathrm{in}$. In diameter. Cores, although described in the same way as cuttings, provide a continuous sample of the formation and therefore a detalled foot-by-foot description. Whole-core samples can be analyzed for porosity and permeability In the laboratory; more commonly, am:ll cores can be taken from the large core and analyzed. 
formations can be obtained from cores, by formation testing devices, and by swabbing. When cores are taken, as previously described, the water in the cores can be carefully extracted and its chemistry analyzed. Contamination is a serious problem, however, since cores have been exposed to infiltration by drilling mud and mud filtrate.

Drill-stem testing is a technique whereby a zone in an open borehole can be isolated by an expandable packer or packers and fluid from the formation allowed to flow through a valve into the drillpipe. The technology of drillstem testing is well described (Pirson).

Swabbing is a method of producing fluid that is similar to pumping a well. In swabbing, fluid is lifted from the borehole through drillpipe, casing, or tubing by a swab that falls freely downward through the pipe and its contained fluid on the downstroke, but which seats against the pipe walls on the upstroke, drawing a volume of fluid above it as it is raised. Swabbing may be used in conjunction with drill-stem testing to increase the volume of fluid obtained. The advantage of swabbing is that it can be continued until all drilling mud has been drawn from the pipe and the formation, i.e., until the chemistry of the water obtained has reached a steady state. This procedure helps to ensure that a representative sample of formation water is obtained.

After a well has been drilled, a variety of borehole geophysical logging tools are available that can be used to produce a record of the nature of the formations penetrated and their contained fluids (Zemanek). In borehole logging, a probe is lowered into a well at the end of a wire cable. Selected geophysical properties are measured as a function of depth and recorded at the surface.

Current methods of well logging are too numerous to discuss in detail here. A broad classification of the more commonly used methods is shown in Table 7, together with their main applications. Because the variety of available logging methods is so great, the suite of methods used in logging a well must be carefully selected to provide the desired information at an acceptable cost. Local practice in the particular geographic area is a valuable guide, since it represents the cumulative experience obtained trom logging many wells. Some of the objectives in logging injection wells will generally be: determination of lithology; bed thickness; amount, location, and type of porosity; and salinity of formation water. In order to achieve these objectives, a commonlychosen suite of logs will include a gamma ray $\log$, a focused resistivity $\log$, and one or more porosity measuring logs selected frotn among the various radiation and elastic wave logs. Some other frequently used logs include the spontaneous and potential (SP) and nonfocused electric logs, the caliper log, and the temperature $\log$. The use of such logs will be discussed further in the review of several case histories of injection-well practice and in the section concerning monitoring (IV.D). A rather extensive review of the application of borehole geophysical logs to wastewater injection has recently appeared (Keys 1973A).

Examination of the records of many of the wastewater injection wells that have been constructed shows that with few exceptions the maximum amount of usable geologic and engineering information has not been obtained during the testing of wastewater infection wells. This is regrettable, because such reats provide the best basis for analyzing reservoir conditions prior to 
Table 7. Well Logging Methods and Their Applications (Modifled after Jennings)

\begin{tabular}{|c|c|c|}
\hline Method & Property & Application \\
\hline Spontaneous Potential & $\begin{array}{l}\text { Electrochemical and } \\
\text { electrokinetic } \\
\text { potentials }\end{array}$ & $\begin{array}{l}\text { Formation water resistivity } \\
\left(R_{W}\right) \text {; Distinction between } \\
\text { shales and nonshales } \\
\text { Bed thickness }\end{array}$ \\
\hline $\begin{array}{l}\text { Nonfocused Electric } \\
\text { Log }\end{array}$ & Reșistivity & $\begin{array}{l}\text { (a) Water and gas/oil sat- } \\
\text { uration } \\
\text { (b) Porosity of water zones } \\
\text { (c) } R_{\mathrm{w}} \text { in zones of known } \\
\text { porosity } \\
\text { (d) True resistivity of } \\
\text { formation ( } \mathrm{R}_{\mathrm{t}} \text { ) } \\
\text { (e) Resistivity of invaded } \\
\text { zone }\end{array}$ \\
\hline $\begin{array}{l}\text { Focused Conductivity } \\
\text { Log }\end{array}$ & Resistivity & $\begin{array}{l}a, b, c, d \\
\text { Very good for determining } \\
\left(R_{t}\right) \text { of thin beds } \\
\text { Depth of invasion }\end{array}$ \\
\hline $\begin{array}{l}\text { Focused and Nonfocused } \\
\text { Microresistivity } \\
\text { Logs }\end{array}$ & Resistivity & $\begin{array}{l}\text { Resistivity of the flushed } \\
\text { zone for calculating } \\
\text { porosity } \\
\text { Bed thickness }\end{array}$ \\
\hline Transmission & $\begin{array}{l}\text { Compressional and } \\
\text { shear wave velocities }\end{array}$ & $\begin{array}{l}\text { Porosity } \\
\text { Lithology } \\
\text { Elastic properties, bulk } \\
\text { and pore compressibilities }\end{array}$ \\
\hline & $\begin{array}{l}\text { Compressional and } \\
\text { shear wave at tenuations }\end{array}$ & $\begin{array}{l}\text { Location of fractures } \\
\text { Cement bond quality }\end{array}$ \\
\hline Reflection & $\begin{array}{l}\text { Amplitude of reflected } \\
\text { waves }\end{array}$ & $\begin{array}{l}\text { Location of vugs, fractures } \\
\text { Orlentation of fractures } \\
\text { and bed boundaries } \\
\text { Casing Inspection }\end{array}$ \\
\hline Gamma Ray & Natural radioactivity & $\begin{array}{l}\text { Shales and nonshales } \\
\text { Shaliness }\end{array}$ \\
\hline Spectral Gamma Ray & Natural radioactivity & Lithologic Identification \\
\hline Gamma-Gamma & Bulk density & Porosity, Lithology \\
\hline
\end{tabular}

(Contd,) 
Table 7. (Contd.)

\begin{tabular}{|c|c|c|}
\hline Method & Property & Application \\
\hline Neutron-Gamma & Hydrogen content & Porosity \\
\hline $\begin{array}{l}\text { Neutron-Thermal } \\
\text { Neutron }\end{array}$ & Hydrogen content & $\begin{array}{l}\text { Porosity } \\
\text { Gas from liquid }\end{array}$ \\
\hline $\begin{array}{l}\text { Neutron-Epithermal } \\
\text { Neutron }\end{array}$ & Hydrogen content & $\begin{array}{l}\text { Porosity } \\
\text { Gas from liquid }\end{array}$ \\
\hline $\begin{array}{l}\text { Pulsed Neutron } \\
\text { Capture }\end{array}$ & $\begin{array}{l}\text { Decay rate of } \\
\text { thermal neutrons }\end{array}$ & $\begin{array}{l}\text { Water and gas/oil saturations } \\
\text { Reevaluation of old wells }\end{array}$ \\
\hline Spectral Neutron & $\begin{array}{l}\text { Induced gamma ray } \\
\text { spectra }\end{array}$ & $\begin{array}{l}\text { Locution of hydrocarbons } \\
\text { Lithology }\end{array}$ \\
\hline Caliper & Borehole diameter & $\begin{array}{l}\text { Calculation of cement } \\
\text { volume } \\
\text { Location of mud cake }\end{array}$ \\
\hline Dipmeter & $\begin{array}{l}\text { Azimuth and incli- } \\
\text { nation of bedding } \\
\text { planes }\end{array}$ & Dip and strike of beds \\
\hline Deviation Log & $\begin{array}{l}\text { Azimuth and incli- } \\
\text { nation of borehole }\end{array}$ & Borehole position \\
\hline Gravity meter & Density & Formation dersity \\
\hline $\begin{array}{l}\text { U1tra-Long Spaced } \\
\text { Electric Log }\end{array}$ & Reststivity & Salt flank location \\
\hline Nuclear Magnetism & $\begin{array}{l}\text { Amount of free hydro- } \\
\text { gen. Relaxation rate } \\
\text { of hydrogen. }\end{array}$ & $\begin{array}{l}\text { Efiective porosity and } \\
\text { permeability of sands } \\
\text { Porosity for carbonates }\end{array}$ \\
\hline $\begin{array}{l}\text { Production or in- } \\
\text { jectivity }\end{array}$ & $\begin{array}{l}\text { Temperature, flow } \\
\text { rate, fluid specific } \\
\text { gravity, pressure }\end{array}$ & $\begin{array}{l}\text { Downhole production or } \\
\text { infection }\end{array}$ \\
\hline Temperature Log & Temperature & Formation temperature \\
\hline
\end{tabular}


infection, for predicting the long-term behavior of the well and the reservoir, for detecting and understanding changes in well performance that may occur during operation, and for analyzing the history of a well from its records.

A well can be tested by pumping from it or injecting into it. Measurements of reservoir pressure or water level can be made during pumping or injection or, alternatively, after cessation of pumping or injection while the reservoir is adjusting to its original conditions.

In the sequence of well construction and testing, the first type of formation test likely to be made is the drill-stem test (DST). As previously mentioned, this test is analogous to a pumping test of limited duration. Quantitative analysis is usually made, using data obtalned during the period of pressure buildup following the period when water from the formation is allowed to flow.

If a test is successful, a series of calculations of formation properties are made from pressure-buildup data. The properties of importance that are routinely calculated are:

1. Static bottom hole pressure

2. Transmisstvity

3. Average efrective permeability

4. Damage ratio

5. Approximate radius of investigation

The static bottom hole pressure, as determined from a successful test, is assumed to closely represent the formation pressure at the elevation of the pressure-recording device. Transmissivity is the average permeability multiplied by the thickness of the test interval. The damage ratio is an indication of the amount of plugging of pores in the formation during drilling of the well. In addition to this routine information, drill-stem tests may Indicate the presence of and distance to nearby faults or facies changes that act as barriers to flow or channels for rapid flow. Detafled presentations of drill-stem test analysis are available (Gatlin, Lynch, Matthews, Pirson).

After an injection well has been drilled and possible injection zones have been identified by corlng, by geophyslcal logging, and by drill-stem testing, injection tests are usually run. Inftial injection testing is of ten done with truck-mounted pumps and treated water rather than wastewater is used for injection. Frequently, more than one possible injection interval is present; tests may be performed on the intervals individually or on more than one at a time. The common practice when performing an injection test is to begin injection at a fraction of the final estimated rate, to inject at this rate for at least several hours, then to repeat this process at increasingly greater rates until a limiting rate or pressure is reached. Injection is then stopped and the reservoir is allowed to return to its original pressure state. Recording of pressures may or may not be continued during this fall-off period.

Regardless of the sequence in which a test is performed, if pressure, t1me, and flow data are accurately recorded and the test is run long enough, $1 t$ is theoretically possible to analyze the test. However, the simpler the test the simpler and probably the more reliable the interpretation. Tests performed 
on more than one zone at a time are particularly difficult to interpret and should be avoided if possible; alternatively, both single-and multiple-zone tests may be performed.

If time data are available on early performance of a well, a form of analysis involving curve matcin ing can be employed. Figure 19 is such a plot of recovery data for an injection well at Mulberry, Florida (Wilson). Thc most interesting aspect of this example is that the test data Indicate an observable amount of leakage through the confining beds. The theory and procedure for analysis of leaky confining beds and two field examples from gas storage projects have been described (Witherspoon 1972).

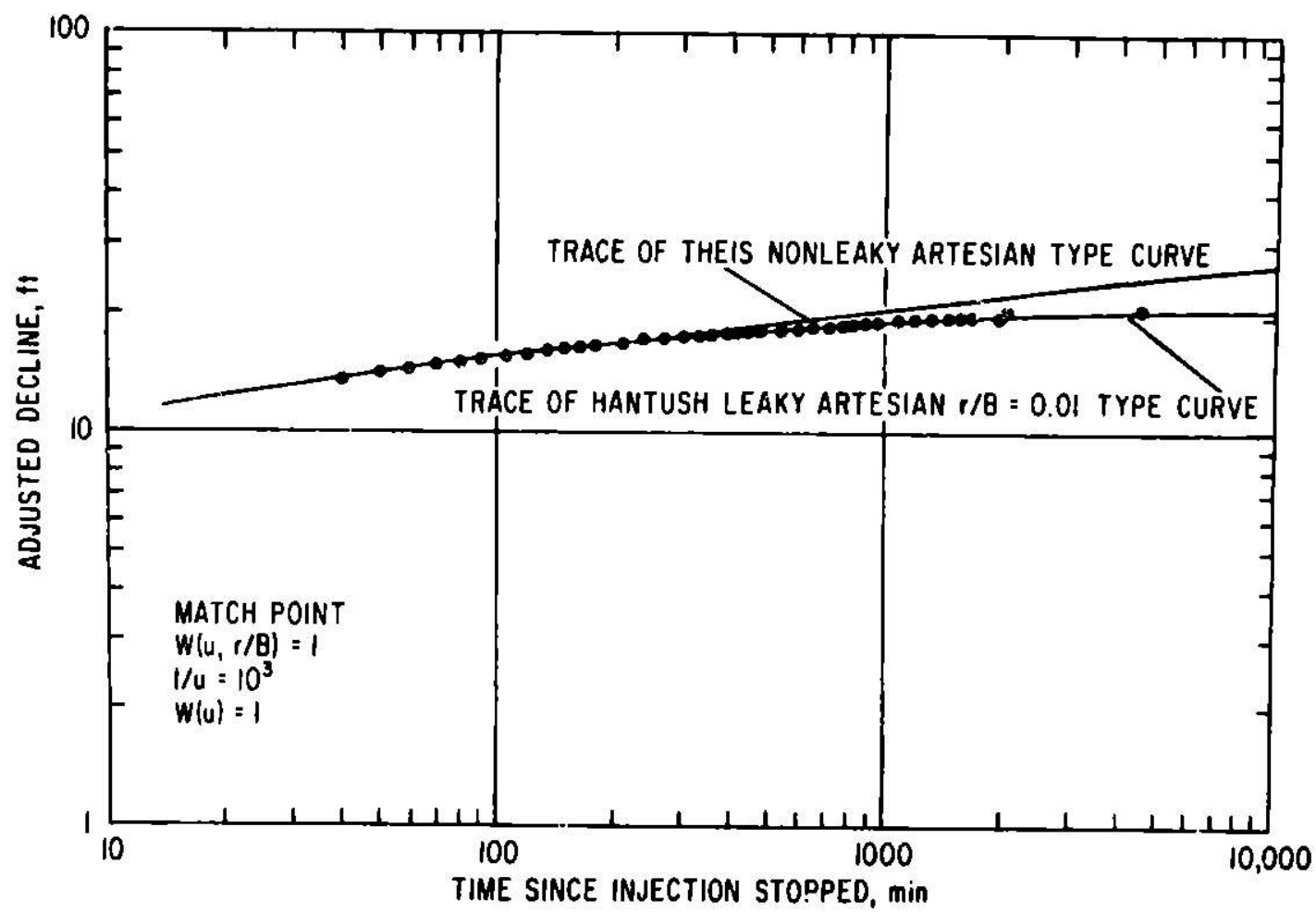

Fig. 19. Plot of Recovery Data and Matching-Type-Curves for an Injection Well (W11son).

Aquifer testing is further described in the references previously given for drill-stem test analysis, particularly in a Society of Petroleum Engineers Monograph (Matthews). Additionally, publications in the groundwater field (Lohman, Kruseman) are excellent recent summaries of this subject, as is a reference prepared for the underground gas storage industry (Witherspoon 1967).

\section{Prediction of Aquifer Response}

\section{Regional Flow}

The basic equation used to describe the flow of fluids in porous media is Darcy's law, alternate forms of which are given by Equations 3, 4, and 5. Darcy's law alone can be used for calculations of steady flow. Steady flow occurs when the quantitles of fluid entering and leaving an aquifer are equivalent so that no change in volume of the aquifer or its contained fluid 
occurs with time.

When flow is unsteady or, as stated in ofl field terminology, when formation pressures are transient, Dari:y's lav must be combined with the continulty equation so that time and the compressibility of the aquifer and aquifer fluids may be taken into account. The appropriate differential equation and its derivation may be found in most modern texts on hydrogeology and petroleum reservolr engineering, along with numerous solutions.

As examples of the application of Darcy's law for steady flow to analysis or regional flow, the velocity of natural flow in the Mt. Simon formation in Uhto and the lower Floridan aquifer in Florida will be considered.

From Fig. 18, it can be seen that, at the location of the EmpireReeves injection well, the hydraulic gradient, dh/dL (Equations 3, 5) is $8 \mathrm{ft} /$ mile toward the northwest, $i . e$. , from the distance (estimated from the given scale of miles) between the contour lines that indicate potentiometric surfaces of 1000 and $600 \mathrm{ft}$ above sea level, the change in helght of potentiometric surface with distance, $\mathrm{dh} / \mathrm{dL}$, is $(1000-600) \mathrm{ft} / 50 \mathrm{mile}$, or about $8 \mathrm{ft} / \mathrm{mile}$. At this location, the Mt. Simon formation has a permeabllity of 24 millidarcies (from a drill-stem test) and a porosity of 10.4 percent (Clifford 1973). Rearranging Darcy's law (Equation 5):

$$
\bar{v}=\frac{Q}{A}=\frac{d h}{d L}
$$

where $\vec{v}=$ apparent velocity through area $A$

then

$$
v=\frac{\bar{v}}{\phi}=\frac{Q}{A \phi}=\frac{K}{\phi} \frac{d h}{d L}
$$

where $v=$ average velocity of flow through pores

- $\phi=$ porosity

Converting the data given above to consistent units and substituting into the Darcy equation gives

$$
\begin{aligned}
v & =\frac{21.36 \mathrm{ft} / \mathrm{yr}}{0.104} \times \frac{8 \mathrm{ft} / \mathrm{mlle}}{5,280 \mathrm{ft} / \mathrm{m} 1 \mathrm{le}} \\
& =0.31 \mathrm{ft} / \mathrm{yr}
\end{aligned}
$$

This evaluation shows that water in the Mt. Simon formation in northcentral Ohio is moving northwest at a rate of $0.31 \mathrm{ft} / \mathrm{yr}$. The source of the hydraulic gradlent and the fate of the moving water are not understood. Furthermore, some complications in the analysis itself have been pointed out (Bond 1973). in spite of uncertainties, the analysis provides an estimated flow rate from which it can be concluded that at this location water in the Mt. Simon formation moves at a negligible rate, if at all.

A further example, Fig. 20, shows the potentlometric surface for the 


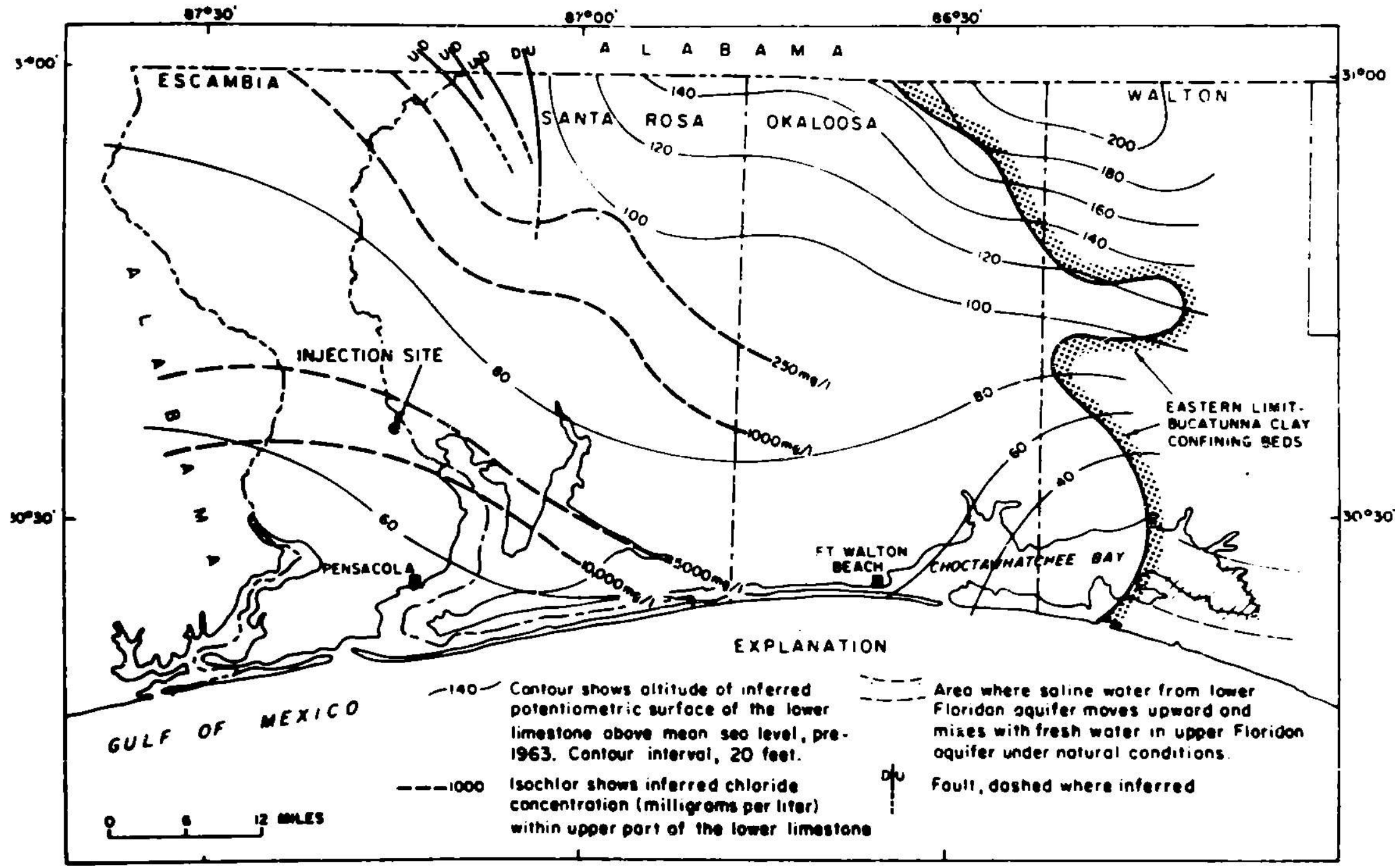

Fig. 20. Hydrogeology of the Lower Floridan Aquifer in Northwest Florida, Indicating the Altitudes of the Potentiometric Surfaces Prior to Injection (Goolsby 1972). 
lower Floridan aquifer in northwest Florida. There the hydraulic gradient was estf.nated to be about $1.33 \mathrm{ft} / \mathrm{mile}$ toward the southwest in the vicinity of the Monsanto Company injection well prior to its operation. The permeability is about one darcy and the porosity is estimated to be 10 percent (Goolsby $1971,1972)$. The velocity of natural flow in the lower Floridan aquifer is then estimated to be:

$$
v=\frac{890 \mathrm{ft} / \mathrm{yr}}{0.10} \times \frac{1.33 \mathrm{ft} / \mathrm{mile}}{5,280 \mathrm{ft} / \mathrm{mile}}=2.24 \mathrm{ft} / \mathrm{yr}
$$

This analysis is more easily interpreted than the previous one for Ohio because it is well known that the source of hydraulic head lies to the north of the injection well site and that the discharge area lies to the south beneath the Gulf of Mexico. The velocity of flow is again very low; it appears that more than 200,000 years would be required for injected waste to reach the estimated subsea discharge point about 100 miles to the south.

\section{Pressure Effects of Injection}

Wastewater injected into deep aquifers does not move into empty voids; rather it displaces existing fluids, primarily saline water. The displacement process requires exertion of some pressure, in excess of the natural formation pressure. The pressure increase is greatest at the injection well and decreases in approximately a logarithmic manner away from the well. The amount of excess pressure required and the distance to which it extends depends on the properties of the formation and the fluids, the amount of fluid being injected, and the length of time that injection has been going on. The pressure or head changes resulting from injection are added to the original regional hydraulic gradients to obtain a new potentiometric surface map that depicts the combined effects of regional flow and the local disturbances.

By use of the theory that has been described, potentiometric surface maps can be produced to show the anticipated situation at any tine in the future. If observation wells exist, the actual potentiometric surface at any time can be constructed from the water levels or pressures recorded in the wells.

Figure 21 shows the theoretical potentiometric surface map for the lover Floridan aquifer in northwestern Florida in 1971, after wastewater injection had been in progress near Pensacola for about elfht years. The estimated pressure effects of injection can be seen by comparing Fig. 20 with Fig: 21 . The comparison indicates that changes in hydraulic head may extend out for 30 miles or more from the injection site. Although Fig. 21 is titled a theoretical potentiometric surface map, it is, in fact, partially substantiated by data obtained at observation wells. If more observation wells were avallable, the map would be constructed entirely from observed data.

Two very important characteristics in solving groundwater flow equations are that (1) individual solutions can be superimposed and (2) hydrologic boundarfes such as faults can be simulated by a properly located imaginary we11. Since solutions can be superimposed, the pressure effects of multiple wells can be easily analyzed. Because the effect of boundaries is analogous to that of properly located pumping or injection wells, the existence of boundaries can be detected by observing aquifer pressure response to injection 


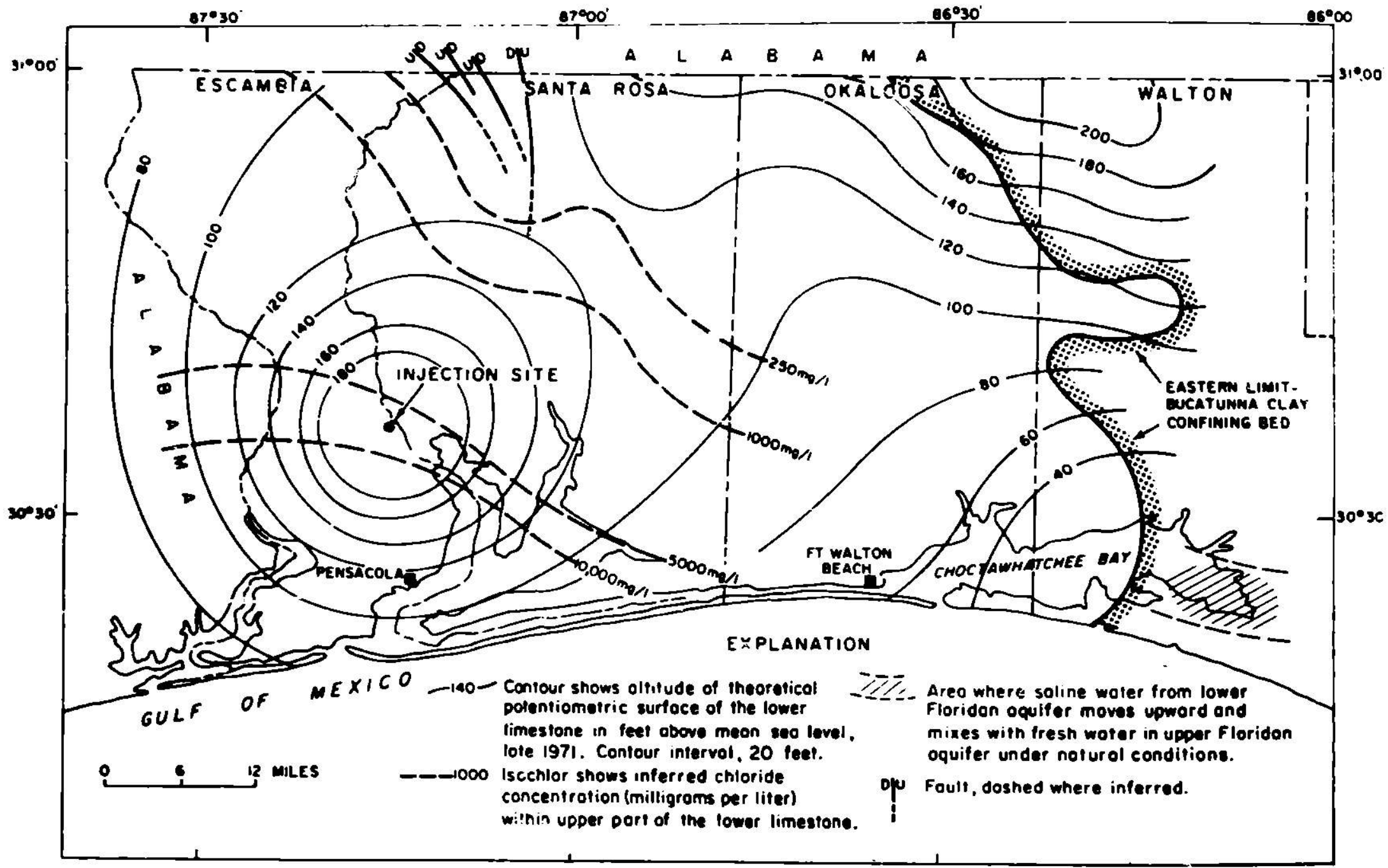

Fig. 21. Hydrogeology of the Lower Floridan Aquifer in Northwest Florida, Indicating the Altitude of the Potentiometric Surface After Wastewater Injection had been in Progress for 8 years; Compare Fig. 20 (Goolsby 1972). 
or pumping; conversely, the effects of known or suspected boundaries on aquifer pressure distribution can be estimated.

\section{Rate and Direction of Fluid Movement.}

As with pressure response to infection, the rate and direction of movement of the injected fluid depend on the hydrogeology of the site; therefore, the same factors previously listed require consideration. In addition the properties of the formation water and the infected wastewater are of mafor Importance.

A good estimate of the minimum distance of wastewater flow from an injection well can be made by assuming that the wastewater will uniformly occupy an expanding cylinder with the well at the center. The equation for this case is:

$$
\mathbf{r}=\sqrt{\frac{\mathrm{v}}{\pi \mathbf{b} \phi}}
$$

where $r$ radial distance of wastewater front from well

$\mathrm{V}=Q t=$ cumulative volume of injected wastewater

$b=$ effective aquifer thickness

$\phi=$ average effective porosity

It is noted that "effective aquifer thickness" and "average effective porosity" should be used. The effective aquifer thickness 1s, for example, that part of a total aquifer that consists of sandstone in the case of a mixed sandstone-shale lithology. The effective porosity has been defined as that part of the porosity in which the pores are interconnected.

In most situations, the minimum radial distance of travel will be exceeded because of dispersion, density segregation, and channeling through high-permeability zones. Flow may also be in a preferred direction, rather than radial, because of hydrologic discontinulties (e.g., faults), selectively orlented permeability paths, or natural flow gradients.

The influence of dispersion can te estimated with the following equation:

$$
r^{\prime}=r+2.3 \sqrt{D r} \quad[L]
$$

where $r^{\prime}=$ radial distance of travel with dispersion

$D$ = dispersion coefficient; $3 \mathrm{ft}$ for sandstone aquifers and $65 \mathrm{ft}$ for limestone or dolomite aquifers

Equation 10 is obtained by solving equation (10.6.65) of Bear (1972) for the radial distance at which the injection front has a chemical concentration of $0.2 \%$ of the infected fluid.

The detalled development of dispersion theory is presented by Bear (1972). The dispersion coefficients given are high values for sandstone and limestone aquifers obtalned from the 11terature. No actual dispersion coefficients are known to have been obtained for any existing injection well. 
10; they were summarized by the Environmental Protection Agency (USEPA 1974) as shown in Table 8 . The calculations revealed that even with dyspersion in 96 percent of the cases and after 50 years of operation, ti: a wastewater will have traveled less than $6000 \mathrm{ft}$ from the infection well. Thus, in most cases, the distance of travel will not be of concern if actual conditions comply even generally with the assumptions made. Even if such calculations are in error by several hundred percent, there would st 111 be no cause for concern in most cases because of the distance from the injection zone to the nearest other well or other known resource.

To proceed beyond the calculations shown may not be necessary, or in many cases may not even be meaningful. However, cases involving additional complications have been discussed. For example, see the discussion of the flow of water from a groundwater recharge well in an aquifer of uniform flow, when the densitles and viscosities of the injected and interstitial fluids are the same (Bear 1974). Also, analytical techniques describing the mixing of injected and Interstitial waters of different densities have been developed (Gelhar 1972).

So far, injected wastewater travel has been considered to occur as an inert fluid that would not (1) react with the aquifer water or minerals, (2) be affected by bacterial action, (3) decompose, or (4) radioactively decay. If the wastewater is not inert, changes in chemical composition with time anc. distance may also need to be considered. Bredehoeft and Pinder (1972) discuss the methodology for a unifled approach to this type of problem and the work of Robertson and Barraclough (1972) presented a model for the distribution of tritium and ${ }^{90} \mathrm{Sr}$ that included the effects of radioactive decay, dispersion, and reversible sorption. However, no single calculational procedure exists at this time that includes the full range of practical possibilities that may be involved in wastewater movement.

In spite of the degree of sophistication used in the development of theories for rate and direction of travel of injected fluid from an injection well, nonunifirm distribution of porosity and permeabllity will preclude making accurate estimates in many cases. In general, wastewater flow in unfractured sand or $\varepsilon$ andstone aquifers would be expected to more closely agree with theory than would flow in fractured reservoirs or in carbonate aquifers with solution permeabllity. However, even in sand aquifers, flow can be expected to be nonideal, as shown by tests reported by Brown and Silvey (1973). Particularly large deviations from predictions may occui in limestone or dolomite aquifers.

\section{Hydraulic Fracturing*}

Hydraulic fracturing may be carried out deliberately to increase formation permeability, or it may occur untententionally during injection testing or wastewater injection if the fracture initiation pressure is exceeded. Regulatory policy may or may now allow short-term hydraulic fracturing operations for well stimulation, but continuous injection at pressures above the fracture point are prohibited by most if not all agencies. The reasons for this policy are the danger of damage to well facilities and the uncertalnty

\footnotetext{
Also refer to discussion of stress in Section III.B.5.
} 
Table 8. Calculated Distance of Wastewater Travel for 148 Injection Wells after 10 and 50 years of Operation ${ }^{a}$

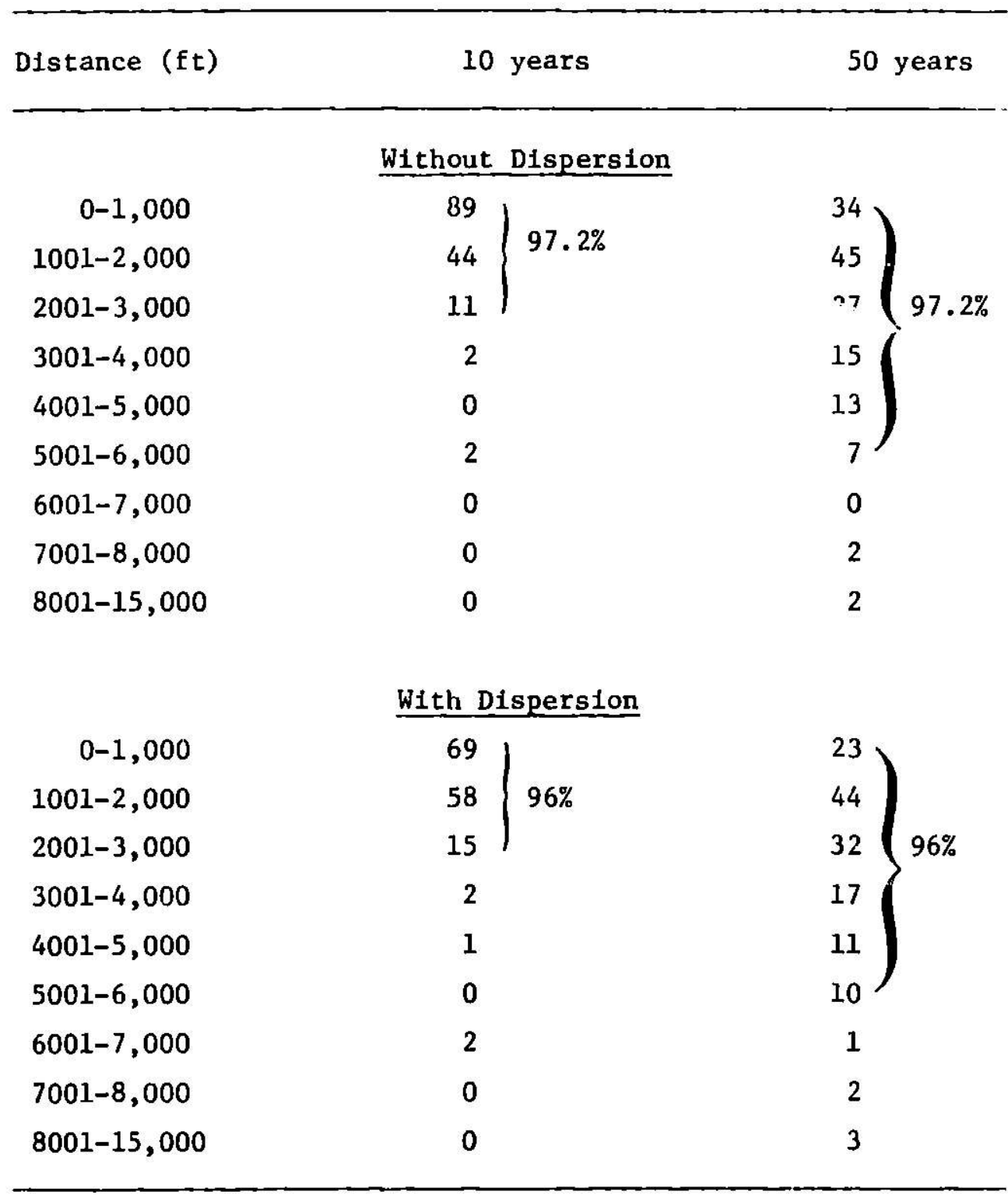

Qusing equations 4-9 and 4-10 from reference USEPA 1974. 
about the destination of the fractures and the injected fluids following them.

Figure 22 shows the relation between bottom-hole pressure and time during hydraulic fracturing. Before injection begins, the pressure is that of the formation fluid $\left(\mathrm{p}_{\mathrm{o}}\right)$ and the column of fluid in the wellbore. Pressure is increased until fracturing occurs, then, as fluid continues to be pumped into the well, the pressure stabilizes at $p_{f}$, the following pressure, and the fractures continue to be extended. When injection ceases and the well is shutin,* the pressure quickly stablilizes to a constant value, the instantaneous shut-in pressure. This pressure is considered to be equal to the least principal earth stress in the vicinity of the well.

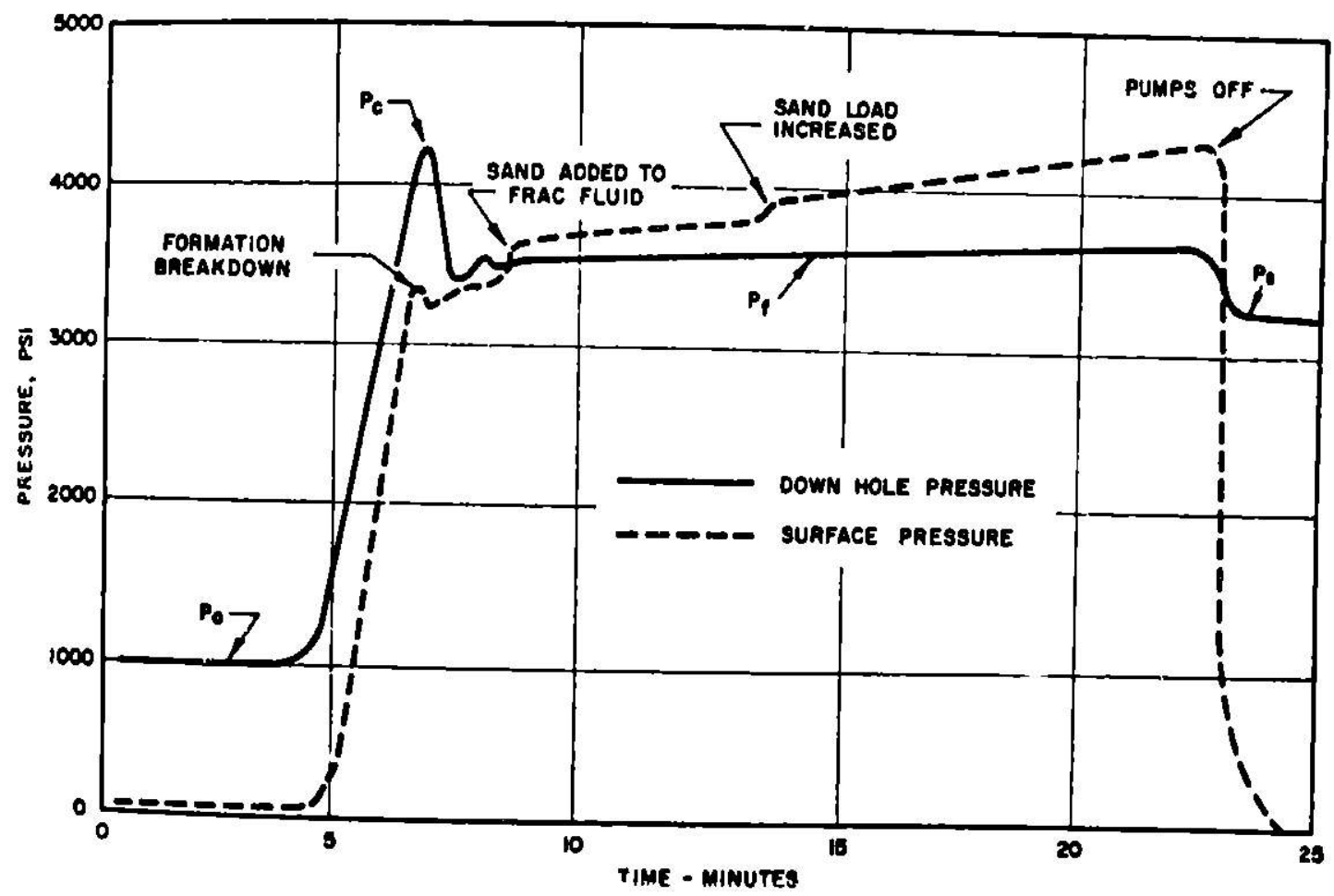

Fig. 22. Pressure-Time Relation During Hydraultc Fracturing (Kehle).

In the estimation of the fluid pressure at which hydraulic fracturing will occur, one of two conditions is usually assumed:

1. That the least principal stress is less than the vertical lithostatic stress caused by the rock column. In this case fractures are assumed to be vertical.

2. That the vertical lithostatic stress is the least princtpal stress. In this case fractures will be horizontal.

In the first case, the minimum bottom-hole pressure required to initiate a hydraulic fracture can be estimated (Hubbert):

$$
p_{1}=\frac{s_{2}+2 p_{0}}{3} \quad\left[F / L^{2}\right]
$$

*All valves are closed of that the well cannot backflow. 
where $P_{\mathbf{i}}=$ fracture initiation pressure

$S_{z}=$ total 11thostatic stress

$\mathrm{p}_{\mathrm{o}}=$ formation fluid pressure

The fracture gradient, that is, the injection pressure required per foot of depth, can be estimated by entering representative unit values into Equation 11. The unit values for $S_{z}$ and $p_{0}$ are, respectively, 1.0 and $0.46 \mathrm{ps} 1 /$ $\mathrm{ft}$. This yields a $\mathrm{P}_{i}$ gradient of $0.64 \mathrm{psi} / \mathrm{ft}$ as a minimum value for initiation of hydraulic fracture. This situation implies a minimum lateral earth stress. As the lateral stresses increase, the bottom-hole fracture initiation pressure also increases up to a limiting value of $1.0 \mathrm{psi} / \mathrm{ft}$. Actually, fracture pressures may exceed $1.0 \mathrm{psi} / \mathrm{ft}$ when the rocks have significant tensile strength and no inherent fractures that pass through the wellbore. In a particular case, injection tests can be run to determine what the actual fracture pressure is, then operating injection pressures can be held below the instantaneous shutin pressure. In the absence of specific data, arbitrary limitations of from 0.5 to 1.0 psi per foot of depth have been imposed on operating injection wells. Regional experience should be used as a criterion in establishing an arbitrary limit, since regional tectonic conditions and fluid pressure gradients dictate what a safe limit will be.

\section{Generation of Earthquakes (Garono, McClain, Kealy)}

The selection of a site for constructing a waste-disposal well should include attention to the chances of seismic occurrences, either induced or natural, and the possible effects of them. It is widely but not universally accepted that a series of earihquakes that began in the Denver area in 1962 was initiated by injection of wastewater into a well at the Rocky Mountain Arsenal. Since sefsmlc activity was assoclated with wastewater injection at Denver, apparently simflar situations have been observed at Rangely, Colorado, and Dale, New York. The former related to water injection for secondary recovery of oil, and the latter to disposal of brine from solution mining of salt. Since there are presently about 160 operating industrial wastewater injection wells and tens of thousands of oil field brine disposal wells that apparently have never caused noticeably seismic disturbance, these three examples must be considered very rare.

It has been erroneously stated by many that the seismic events have been stimulated by "lubrication" of a fault zone by injected fluids. What has happened, if Injection has been involved, is that the water pressure on a fault plane has been increased, thus decreasing the friction on that plane and allowing movement and consequent release of stored seismic energy.

Based on this interpretation of the mechanism of earthquake triggering by fluid injection, some of the conditions necessary for the inducement of such earthquakes would be:

1. A fault within a region containing forces having the potential for causing movement of the blocks on either side of the fault plane, but which are being successfully resisted by frictional forces. 
2. An injection well close enough to the fault, vertically and horizontally, so that the fluid pressure changes caused by injection are transmitted to the fault plane.

3. Injection at a rate and a duration sufficient to increase fluid pressure on the fault plane to the point that frictional forces resisting movement are less than the forces tending to cause movement. At this time, movement occurs and stored seismic energy is released. That is, ain oarthquake occurs.

As discussed earlier in the section on state of stress, relatively little is known about stress distribution in the earth's crust, and even less is known about stress distribution along fault systems. In the absence of this information, only qualitative estimates can be made of the probability of earthquake stimulation. In most cases, the potential for earthquake stimulation is non-existent or negligible because only very limited areas in the country are susceptible to earthquake occurrence. The susceptible areas are delineated by records of earthquakes that have occurred in the past and by tectonic maps that show geologic features which are assoctated with belts of actual or potential earthquake activity.

In a case where subsurface stresses are known or are determined by nydraulic fracturing or other means and where the location and orientation of the fault plane are known, a quantitative estimate of the pressure required to cause fault movement can be made. Raleigh (1972) provides an example of such a calculation from the Rangely, Colorado, oil field. Depending on the individual situation, it might be recommended that the distance from the wellbore to the nearest known fault be greater than the radius of pressure influence of the well. If there is no fault nearby, the likelihood of an earthquake caused by the well is expected to be negligible.

\section{E. Characteristics of Sedimentary Basins in the United States}

Synclinal sedimentary basins and the Atlantic and Gulf Coastal plains (Fig. 23) are particularly favorable sites for deep waste-injection wells because they contain relatively thick sequences of salt-water-bearing-sedimentary rocks and because commonly the subsurface geology of these basins is relatively well known. Galley (1968) discussed general aspects of geologic basin studies as related to deep-well disposal of radioactive waste.

During the early 1960s, a series of reports concerning the suitability of selected basins for radioactive waste disposal was prepared for the Atomic Energy Commission by the U.S. Geological Survey. These reports included ones by Repenning (1961) on the Central Valley of Calffornia, Sandberg (1962) on the Williston basin, Beikman (1962) on the Powder River basin, MacLachlan (1964) on the Anadarko basin, LeGrand (1962) on the Atlantic and Gulf Coastal Plains, and Colton (1961) on the Appalachian basin; Love and Hoover (1960) briefly summarlzed the geology of many sedimentary basins in the United States.

In addition to the USGS basin reports, members of a subcomnittee of the Research Committee of the Anerican Association of Petroleum Geologists prepared reports for the AEC on portions of the Appalachian basin, the Michigan basin, the Salina basin, the Denver basin, and the San Juan basin (Galley 1968). 


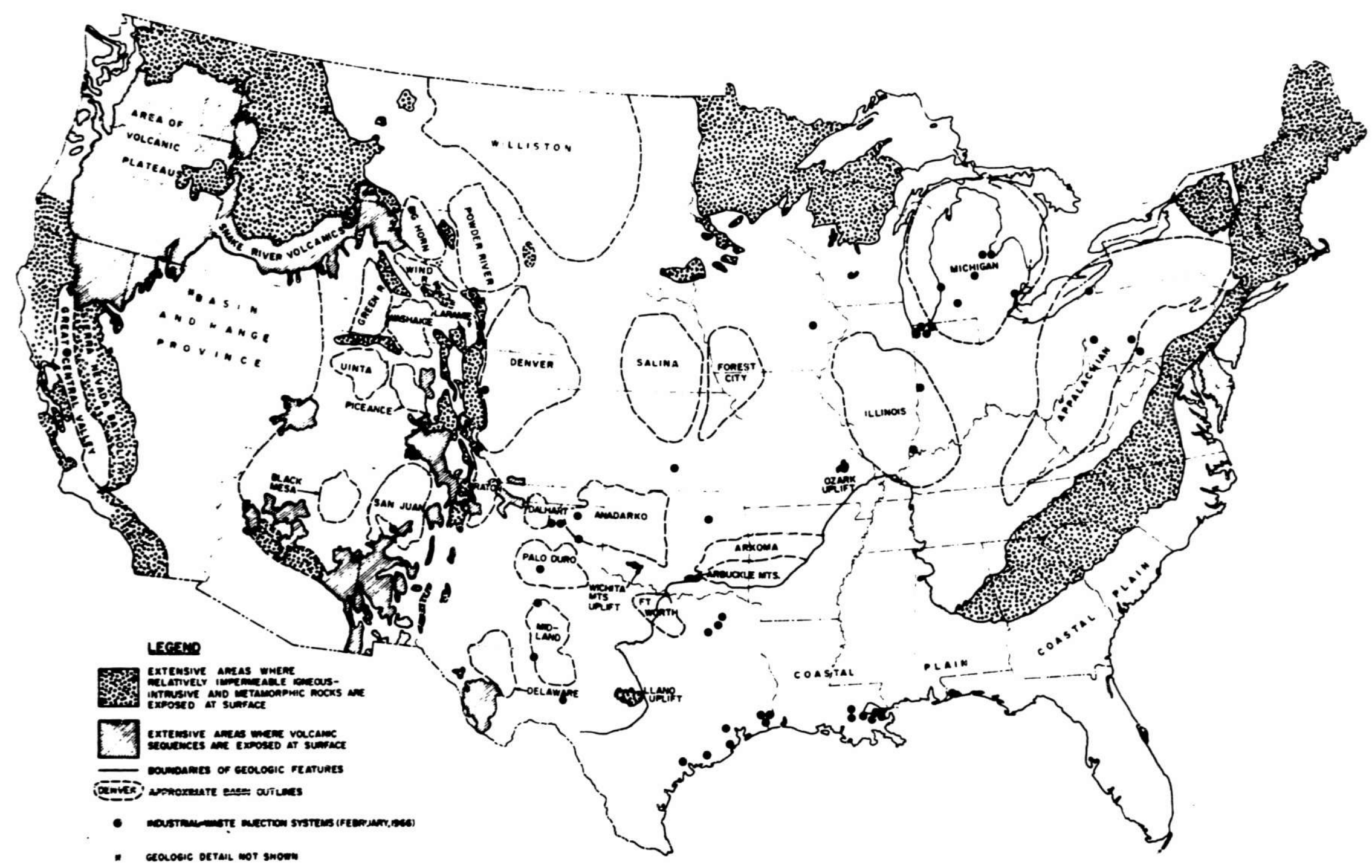

Fig. 23. Geologic Features Significant in Waste-Injection Well-Site Evaluation and Locations of Some Industrial Wastewater Injection Systems (Warner 1968). 
Just as major synclinal basins are geologically favorable sites for wastewater injection, cther areas may be generally unfavorable because the sedimentary-rock cover is thin or absent. Extensive areas where relatively impermeable igneous-intrusive and metamorphic rocks are exposed at the surface are shown in Fig. 23. With the possible exception of small parts, these areas can be eliminated from consideration for waste injection. The exposure of igneous and metamorphic rocks in the Arbuckle Mountains, Wichita Mountains, Llano, and Orzak uplifts, the exposures just south of the Canadian Shield, and other such exposures are perhaps not extensive, but they are significant because the sedimentary sequence thins toward them and the salinity of the formation waters decreases toward the outcrops around the exposures.

Regions shown in Fig. 23 where a thick volcanic sequence lies at the surface generally are not suitable for waste-injection wells. Although volcanic rocks have fissures, fractures, and interbedded gravel that accept injected fluids, they can be expected to contain fresh water.

immense and geologically complex Basin and Range Province is a series of narrow basins and intervening, structurally positive ranges. Some of the basins might provide waste-injection sites, but their geology is mostly unknown and the cost of obtaining sufficient information to ensure safe construction of injection wells could be high.

The geology of the West Coast is complex and not well known. Relatively small Tertiary sedimentary basins in southern California yield large quantities of oil and gas and probably are geologically satisfactory sites for wasteinjection wells. There are similar basins along the coast of northern California, Oregon, and Washington, but little is known about their geology.

Areas not underlain by major basins or prominent geologic features may be generally satisfactory for waste injection if they are underlain by a sufficient thickness of sedimentary rocks that contain saline water, and if putential injection zones are sealed from fresh-water-bearing strata by impermeable confining beds.

A number of discussions have appeared in recent years that describe the feasibility of industrial wastewater injection in individual states and one region, including those by Bergstrom (1968) on Illinois, Kreidler (1968) on , Newton (1970) on Oregon, Rudd (1972) on Pennsylvania, Clifford (1972) Tucker and Kidd (1973) on Alabama, and ORSANCO (1973) on the Ohio River valley region. To some extent these reports include previous analyses, but they also describe interbasin areas and discuss state requirements and regulatory experience.

It should be realized that rarely, if ever, will any of the listed reports furnish more than a preliminary evaluation of the suitability of a specific site, unless the site is in a totally unacceptable location (in which case no further evaluation is needed). If a site is located in a generally acceptable area, a detalled examination should be made of the local geology and subsurface hydrology prior to construction of a test well, and a reevaiuation silould be made after the well has been constructed and tested. 
Often, much of the information available for local site evaluation is in the hands of the geological survey of the state where the site is located. Additional possible information sources are other state agencies, e.g., divisions of oil and gas, water surveys, bureaus of mines, and environmental protection agencles, federal agencies, particularly the U.S. Geological Survey and the U.S. Environmental Protection Agency; and ofl and perhaps mining companies operating in the area. In oil-and gas-producing areas, it is common to find companies that collect and provide well logs and other subsurface information for very reasonable charges in comparison with what it costs to locate and duplicate the information independently. Unfortunately, geologic and subsurface engineering information is used in a variety of ways and thus far these data have not been collected and filed in a way allowing automatic retrieval for evaluation of an injection well. site. Hidalgo and Woodford (1973) describe a project in which data from well logs and hydraulic fracturing records for a 1785-snuare mile area in West Virginia were trassferred in romputer cards; these data were then used to prepare computer-drawn maps for preliminary injection-well site evaluation. This was, however, an experimental effort. Such a capability is not generally ava1lable.

In sumnary, decisions on the suitability of a site for deep-well injection of wastewater should be based on a number of informational sources, including (1) recorded infcrmation on stratigraphy, structure, and lithology (composition and texture) of ruck strata; (2) the chemical composition, viscosity, pressure, and compressibility of native subsurface water; (3) porosity, permeability, compressibility, temperature, ind state of stress of rock units; (4) the flow of vatural water and its relevance to waste containment; and (5) the resources of the region and the pussible effects of waste injection on their valie. Data describing the subsurface of a regton may be available prior to drilling from records of state geologic surveys, oil and gas agencies, water-resources agencies, and private companies. Geologic information that would be useful in site evaluation is not yet generally retrlevable through automatic data processing techniques. The suitability of a site for waste injection can be evaluated as drilling proceeds from analyses of rock samples and formation fluids, by a large number of borehole geophyslcal logging techniques, and from tests that involve pumping fluld into or out of the well at various stages of completion. In assessments of the suitability of a site, the effects on subsurface flow of natural fluids in the region of influence, the effects of pressure, the rate and direction of flow of the waste, and the possibility of the stimulation of earthquakes should be considered. Suitable sites for deep-well injection are most likely to be found in the major sedimentary basins of the U.S. The sum of the areas of these basins is large. Descriptions of the sedimentary basins of the eastern and middle sections of the U.S. are generally available in detail, whereas some of the far-western basins are less well characterized.

\section{DESIGN, CONSTRUCTION, AND OPERATION OF INJECTION SYSTEM}

The injection system includes all facilities required for transmission, treatment, storage, injection, and monitoring of the low-level wastewater after it leaves the evaporators. Design of these facilities and system operaition and monitoring are considered in this chapter. 


\section{A. Surface Equipment}

Almost all wastewaters require some degree of pretreatment before they can be successfully injected for extended periods of time. Table 9 lists characteristics that have been found to cause difficulties during wastewater injection and lists means of controlling the problems caused by these characteristics.

In order to provide control of wastewater characteristics, surface equipment incluiing flow lines, holding tanks, pumps, filters, gauges, controls, and standby facilities will be required for preparing wastewater for injection and, possibly, for handling it in the event of a well failure.

In the absence of detailed data characterizing LLAW from commercial experience, the characteristics outlined in Table 2 (e.g., the volume rate, chemistry, and $\mathrm{pH}$ given in footnotes) will be used as the basis for calculating the capacity of the pretreatment system. Figure 24 is a diagram of a preinjection waste treatment scheme for an acidic industrial wastewater. The layout is applicable to low-level radioactive wastewater, with some possible modifications.

Although the chemical purity of LLAW may suggest that filtration equipment may not be warranted in the system (FIg. 24) for preinjection treatment, a real wastewater may contain suspended solids not now anticipated and therefore require primary filtration; also, filtration of a "process upset" waste may be necessary because of the precipitation of iron and possibly other metals when the $\mathrm{pH}$ is raised to neutrality. The cost of filtration equipment is expected to be much less than the cost of clearing a plugged well.

'lemporary storage capacity might also be added in the event of temporary shutdown of the injection well. An aiternative to such storage capacity would be a standby well.

As shown in Table 2, the normal low-level waste is expected to have an $\mathrm{HNO}_{3}$ concentration of $0.01 \mathrm{~mol} /$ liter or a $\mathrm{pH}$ of about 2 ; but when the waste evaporators are not in operation, the $\mathrm{HNO}_{3}$ concentraticn could reach $1-2$ molar or a $\mathrm{pH}$ of 0 to -0.3 . Although evaporator failure is uct expected to be $\mathrm{fr} \in \mathrm{quent}$, it must be planned for. A rough indication of eraporator reliability, based on the experience at the Idaho Chemical Processing Plant, leads to the expectation that failure (mainly from tubing bundle corrosion) may be expected to occur every 1 to 5 years, resulting in a downtime of 1 to 2 days (Lohse). The probable method of adaptation when evaporators are down would be to increase the amount of chemicals for neutralization of the $\mathrm{HNO}_{3}$. This would not be a problem, since only 0.0005 gallon of 50 percent $\mathrm{NaOH}$ is required to neutralize a gallon of the normal waste and 0.005 to 0.01 gallon of $\mathrm{NaOH}$ is required per gallon of process upset waste. The corrosive nature of the low-level waste prior to neutralization requires that pipes, tanks, and transfer pumps be constructed of special materials. Past experience of the nuclear industry has shown that stainless steels of types $309 \mathrm{SCb}, 321,347$, and $304 \mathrm{~L}$ are suitable in Purex operations (Long).

Surface controls should include $\mathrm{pH}$ and suspended-solids monitors that will automatically recycle the waste if the treatment equipment fails to provide 
Table 9. Undesirable Characteristics of Wastewater for Injection Purposes and Means of Control

Undesirable Characteristic

I. Suspended Solids

II. Entrained or Dissolved Gas

III. Chemical Reactivity

A. W1th system components

B. With formation minerals

C. With formation fluids

D. Autoreactivity

IV. Blological Growths

\section{Means of Control}

Chemical coagulation

Sedimentation

Centrifugation

Filtration

Chemical or mechanical degasification

1. Chemical treatment

2. Ion exchange

3. Use of corrosinn-

resistant materials

4. Cathodic protection

1. Chemical treatment of wastewater

1. Items A.1 and A. 2 above

2. Use of a buffer zone

1. Items A.1 and A. 2 above

2. Encourage reaction prior to injection

1. Filtration

2. Addition of biocides 


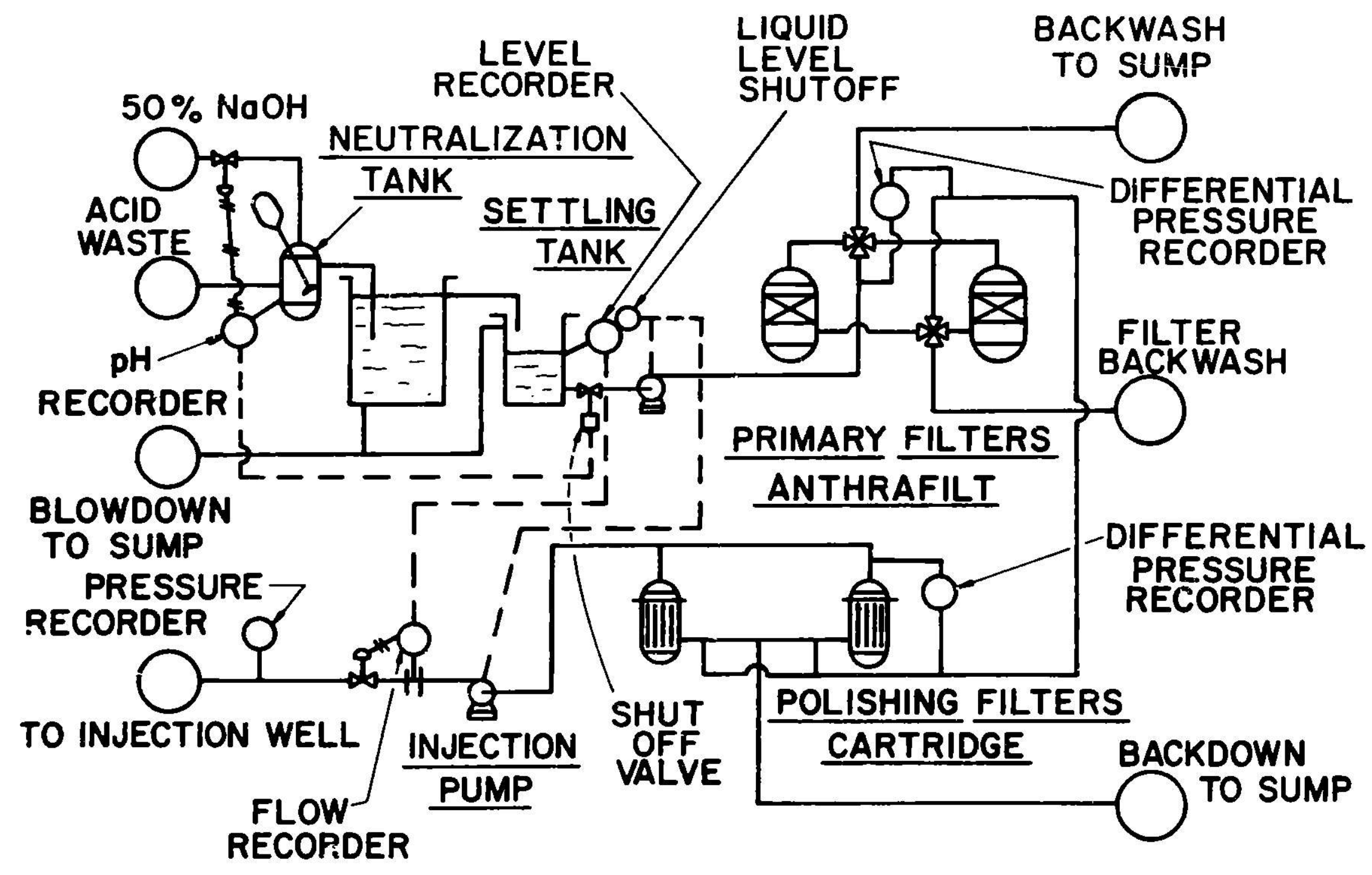

Fig. 24. Schematic Example of Preinjection Waste Treatment Facilities for an Acid Industrial Wastewater (Moseley). 
adequate neutralization or solids removal. This is a critical r: quirement, since well failure could occur quickly if either of these characteristics is allowed to deviate from design specifications.

In addition to neutralization, one other treatment of LLAW may prove necessary to preserve the permeability of the receiving stratum based on the following considerations. Clay minerals are common constituents of sedimentary rocks. Roedder (1959) stated that there might be no sandstones containing less than 0.1 percent clay minerals anywhere in the United States, except possibly in small deposits of exceedingly pure glass sand. Clay minerals are known to reduce the permeability of sandstone to water as compared with its permeability to air. The degree of permeability reduction to water as compared with air has been termed the "water sensitivity" of a sandstone.

The water sensitivity of clay-bearing sandstones increases with decreasing water salinity, decreasing valence of the cations in solution, and increasing $\mathrm{pH}$ of the water. The water sensitivity of a sand depends on both the type of clay mineral and the amount. The properties that cause clay minerals to reduce sandstone's permeability to water are exh1bited by montmorillonite to a marked degree, by illite to a lesser degree, and by kaolinite to a relatively unimportant degree. Water sensitivity of sandstones can be determined directly by permeability tesls with varlous waters and air or indirectly by $x$-ray diffraction, differential thermal analysis, or water vapor absorption measurements.

Low-level radioactive wastewaters contain a very small amount of dissolved chemicals in comparison with the natural waters that will be displaced during injection. Also, it is suggested that the wastewater be neutralized with sodium hydroxide. Under these conditions, the maximum potential for deflocculation of clays and $108 s$ of permeability would exist. If the rock units to be used for infection are found to be water sensitive, the wastewater may require chemical modification to avoid this problem. Optimum permeability of water sensitive rocks can be maintained by adjustment of the salinity, Ionic composition, and pll of the infected water or possibly by adding a flocculating agent to the injected water.

The actual procedure to be used should be selected on the basis of results of laboratory tests on cores. Since the need for treatment and the treatment that may be required cannot be anticipated in a general discussion, no consideration of this pretreatment step will be included in the surface facillty design or cost analysis.

\section{B. Well Degign and Construction}

The principgl steps in the design of an injection well and its mechanical components include selection of (1) completion method and bottom-hole equipment; (2) tubing and casing (size, grade, welght, and type); and (3) cementing program.

Some drilling, testing, and logging must be carrled out in order to ascertain whether a well should be completed. The completion phase includes: Inetallation and cementing of casing; Installation of tubing, perforating or

slotting of the casing; and otimulating the injection horizon. Generally, it Is necessary to Install and cement some of the casing during drilling. 
Installation of casing strings must provide for space around the casing for adequate cement. Rock formations penetrated should be sampled during drilling; geologic and hydrologic data may be obtained from formation cores or water samples at horizons of particular importance, using methods discussed in Chapter III.

\section{Bottom-Hole Completion}

The method of bottom-hole completion is dictated by geologic conditions. The functions of well casing and associated equipment should be considered in determining a completion method. Casing is the steel or steelalloy pipe used in a disposal well:

1. to support borehole walls,

2. to prevent inter-aquifer witer transport,

3. to prevent injected waste from entering aquifers other than those selected for disposal, and

4. to provide a conduit for equit int and fluids.

Casing is manufactured in sections having lengths of 16 to over 36 feet; sections are screwed or welded together.

Conductor casing is the largest-diameter casing used and is required only where the surface solls are so incompetent that the washing and eroding action of the drilling mud would create a large cavity at the surface. The next sinaller diameter of casing is the surface casing, used to protect freshwater sards. The amount of surface casing required depends on the depth of fresh-water sands in an area, which may vary from a few feet to several thousand feet. In most states, a state regulatory body determines the amount of surface casing which must be used in any particular area.

After insertion and cementing of surface casing, the number of strings of additional casing required depends on the depth of the well and the problems found in drilling. If the well is unusually deep or if severe drilling problems arc encountered (e.g., abnormal formation pressures, heaving formations, or lost (irculation zones), Intermediate strings of casing may be necessary to seal of a long open hole or the trouble zones. After all necessary intermediate strings of casing have been set, the long string or infection string is set Immediately above or through the infection interval.

Whereas the term casing 18 generally applied to plpe which extends from the surface down to 1ts "setting depth," the term liner is generally applied to strings of pipe which do not extend to the surface. Liners may serve as the infection string through several huidred feet in the bottom part of a well. Liners are also used for special purposes, e.g., the slotted IIners, perforated liners, and gravel-packed liners which are set opposite injection zones to prevent sand from entering the well. Liners may be cemented in place, or may be set with packers at their top or bottom or hoth, or may merely be set on the bottom of the well. Liners that are slotted or constructed of wrapped wire to prevent sand entry are also referred to as screens. A section of pipe may be partly blank IIner and partly screen, with the blank liner set opposite impermeable zones and the screen opposite permeable zones. 11 waste fluld may be injected through the long string, through liner, or most uftell 
through tubing that extends from the surface to some point within the injection interval. Tubing and liner are of ten closed of $f$ from the long casing string with packers to prevent fluids from circulating between the tubing, liner, and casing.

Methods of bottom-hole completion are illustrated by Fig. 25 and the following, corresponding descriptions using the terminology introduced above:

I. Competent Formations

a. Open hole. The simplest and least expensive method involves setting casing to the top of the injection horizon and providing no support for the hole within the horizon. This type is commonly used in limestone or hard sandstone characterized by no sloughing into the hole, and by permeability discontinuously distributed through a very thick interval.

b. Screen and liner. Fornation sloughing into the hole, can be countered by the use of a section of liner and screen set through the interval.

c. Screen and liner with packer. This type is used to counter formation sloughing, where it is necessary to close off the annulus between the liner and the casing with packer.

d. Underreamed with gravel packed around screen. When liner and screen cannot control sloughing of sand, gravel, sized to bridge the screen openings, and in turn to provide a bridge for the sand, is packed around the screen.

II. Caving Formations, Thin Injection Zones

e. Perforated casing only. Where formations need substantial support, or where thin injection zones are encountered, casing can be cemented through the injection zone. When the cement has set, the casing is perforated by means of gun or jet perforators.

i. Perforated casing with screen. Minor amounts of sand entering the well through the casing perforatiens, may be controlled by a screen hung inside the casing, through the interval.

8. Perforated casing, gravel squeeze, and screen. In an Incompetent formation producing much sand, the casing can be set, cemented, and perforated, and the surrounding sand can be washed out and replaced with supporting gravel. The screen lo set by washing it into the gravel.

h. Perforated casing and "permonent" type completion. In a "permanent" completion, the tubing 18 set in the well before perforat ing and is not removed during 1ts $11 \mathrm{fe}$. Tools for workovers, logging, and perforating may be run and retrieved on a wireline. This artangesent gives quick, cheap completions and 


\section{COMPETENT FORMATIONS}

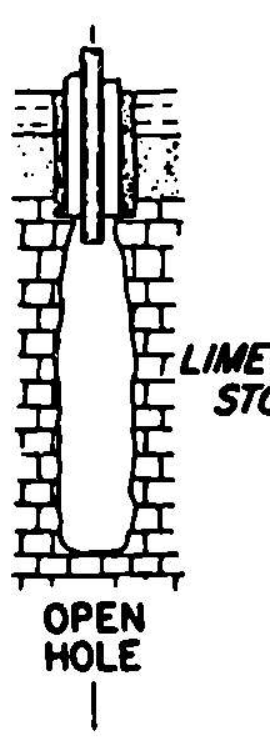

(a)

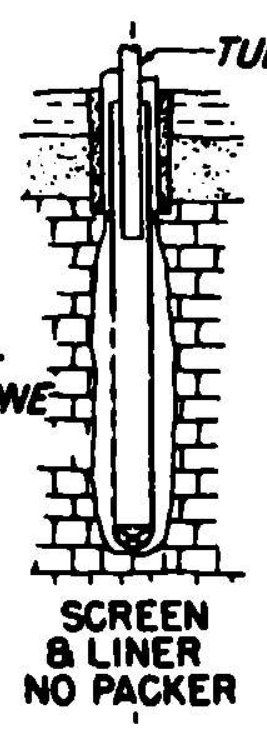

(b)

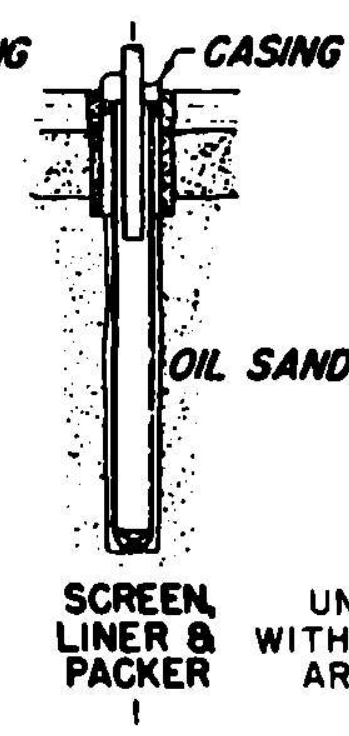

(c)

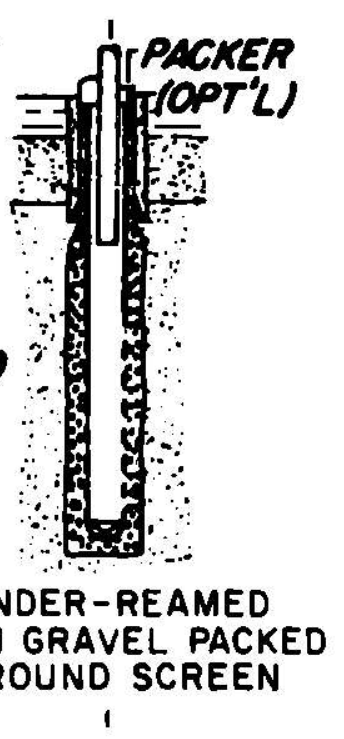

(d)

\section{CAVING FORMATIONS}

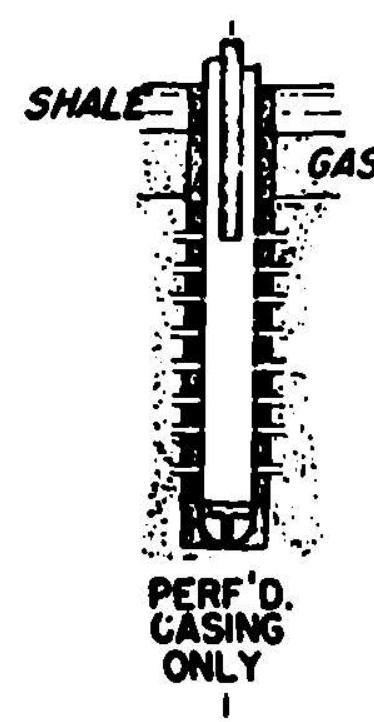

(e)

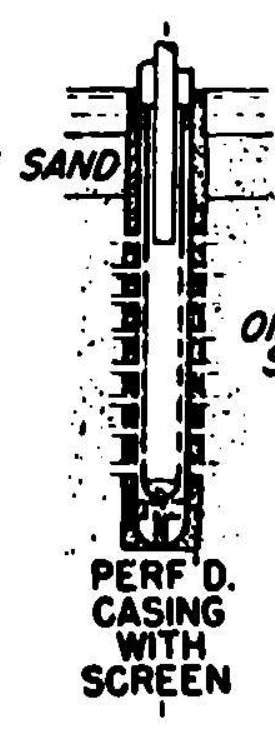

(f)

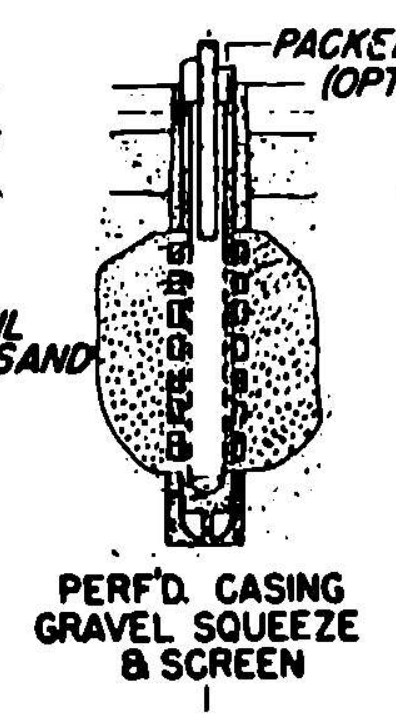

(q)

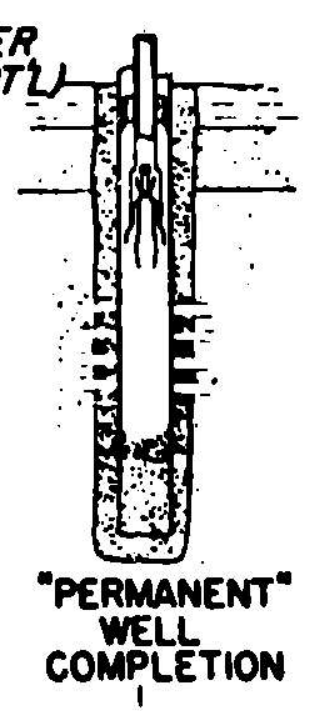

(n)

F18. 25. Methods of Well Completion (API 1955).

low-cost workovers. The tools are small and intricate, and their use may be 1 imited under corrosive conditions.

Because of geologic conditions, infection wells in the north-central atates are generally completed open-hole, as in completion method a. In the Gulf Coast area, where unronsolidated sands are the injection tarsets, wills 
are completed $w^{-t h}$ the casing or liner extending to the bottom of the hole, as in $c$ through $h$. Completion method $d$ has generally emerged as the most successful in that geologic province.

\section{Selection of Casing and Tubing}

Presumably, all wastewater injection wells will be constructed with injection tubing inside the long casing string and with a packer set between th..: tubing and the casing near the bottom of the casing (Fig. 26). This design is not entirely free of problems, particularly with the packer, but experience has proved it generally superior.

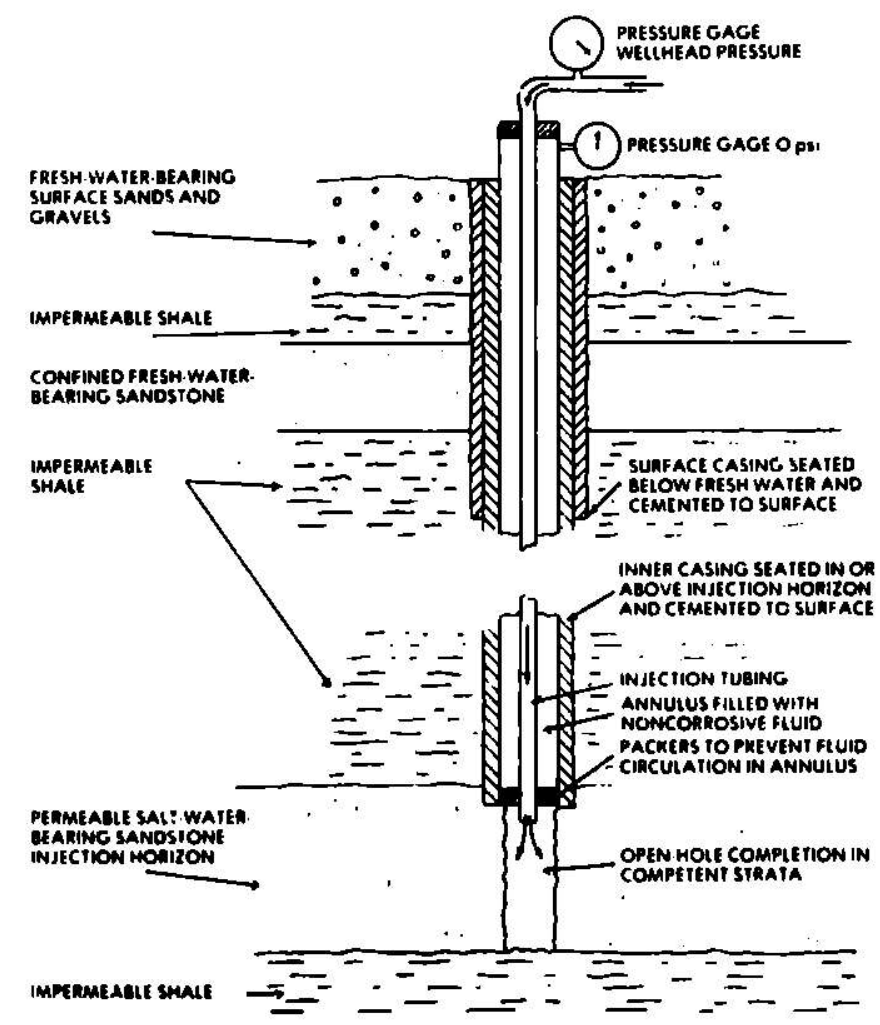

F1g. 26. Schematic Diagram of an Industrial Waste Infection Well

Completed in Competent Sandstone (Modified after Warner 1965).

Pipe in a well is subject to external pressure, internal pressure, longitudinal or axial loading, and corrosion. The problem of designing strings of tubing and casing is one of selecting the most economical combinations that will withatand these forces and convey the injected fluids. Specifications for tubing and casing have been established by the American Petroleum Institute (API 1973). The API standards address six properties: nutside diameter, wall thickness, materlal grade, Jolnt type, folnt length, and untt weight.

Tubing alze is based on the volume to be infected, but chere is no fixed relation between the two. For a specifled waste volume, an increased tubing size requires less energy to force the wastewater through the tubing, but an increased tubing cost. The optimum tubing size would minimize the cost of operation and still meet the engineering requirements of the system. 
The approach suggested here is to minimize the initial construction cost. For the small volumes to be injected at a fuel reprocessing plant (e.g., 35 gpm), $27 / 8$ in. OD tubing would be satisfactory. Selection of the grade, weight, and type of tubing would require that the well depth and operating conditions be known.

Factors in determining the size of the long or injection string are:

1. Tubing diameter. The inside diameter of the casing must be great enough to accommodate the tubing and packer.

2. Cost of drilling and casing. Since the cost of drilling and casing increases with hole diameter, the size should be minimized.

3. Workovers. Since remedial work is frequently necessary in wastewater injection wells, the casing size must accommodate workover equipment. During their lifetimes, many injection wells require some form of maintenance ("workover" in the terminology of the petroleum industry). Workovers are commonly done for the following purposes:

(1) Well repalr

a. Replace damaged tubing and/or packers

b. Repair damaged or corroded casing

c. Perform remedial well cementing

d. Install additional liners or casing

(2) Maintenance of infection capacity

a. Reperforating

b. Acidizing

c. Fracturing

d. Mechanical or hydraulic cleaning of the wellbore

(3) Recompleting or deepening to a new infection interval

4. Common practice. The experience of others in the geologic areas of interest and in similar operating situations should gulde the final choice.

Based on these criterla, an injection casing size of 7-in. OD is suggested. Although a smaller size could be used, it would limit the chotce of packers and make remedial workovers more difficult. A decision on the size of the infection casing fixes the minimum size of the hole and of all larger casing sizes (Tables 10 and 11 ).

These tables Indicate that the hole size for 7 in. casing will be $97 / 8 \mathrm{in}$. This minimum size 18 necessary to provide clearance for the mud cake on the hole walls and for casing appliances. The hole dlameter should be at least $2 \mathrm{in}$. greater than the casing diameter to allow at least a $1-1 \mathrm{n}$. sheath of cement around the casing (API 1958).

For this example, it will be assumed that only one other casing string, :he surface casing will be needed. API speciflcations indicate the 
Table 10. Determination of Recommended Bit Sizes ${ }^{a}$ for API Casing (Blum).

\begin{tabular}{|c|c|c|c|c|}
\hline $\begin{array}{l}\text { Casing } \\
\text { OD }\end{array}$ & $\begin{array}{l}\text { Coupling } \\
\text { OD }\end{array}$ & $\begin{array}{l}\text { Recommended } \\
\text { Clearance }\end{array}$ & $\begin{array}{l}\text { Minfmum } \\
\text { Hole Size }\end{array}$ & $\begin{array}{l}\text { Minimum } \\
\text { Bit Size }\end{array}$ \\
\hline $\begin{array}{ll}4 & 1 / 2 \\
5 & \\
5 & 1 / 2 \\
6 & \\
6 & 5 / 8\end{array}$ & $\begin{array}{l}5.000 \\
5.563 \\
6.050 \\
6.625 \\
7.390\end{array}$ & $\begin{array}{l}1.000 \\
1.250 \\
1.250 \\
1.750 \\
1.750\end{array}$ & $\begin{array}{l}6.000 \\
6.813 \\
7.300 \\
8.375 \\
9.140\end{array}$ & $\begin{array}{ll}6 & \\
7 & \\
7 & 3 / 8 \\
8 & 3 / 8 \\
9 & 1 / 2\end{array}$ \\
\hline $\begin{array}{rr}7 & \\
7 & 5 / 8 \\
8 & 5 / 8 \\
9 & 5 / 8 \\
10 & 3 / 4\end{array}$ & $\begin{array}{r}7.656 \\
8.500 \\
9.625 \\
10.625 \\
11.750\end{array}$ & $\begin{array}{l}2.000 \\
2.500 \\
3.000 \\
3.250 \\
3.250\end{array}$ & $\begin{array}{r}9.656 \\
11.000 \\
12.625 \\
13.875 \\
15.000\end{array}$ & $\begin{array}{rl}9 & 3 / 4 \\
11 & \\
13 & 3 / 4 \\
14 & 3 / 4 \\
15 & \end{array}$ \\
\hline $\begin{array}{ll}11 & 3 / 4 \\
13 & 3 / 8 \\
16 & \\
20 & \end{array}$ & $\begin{array}{l}12.750 \\
14.375 \\
17.000 \\
21.000\end{array}$ & $\begin{array}{l}3.500 \\
3.500 \\
3.500 \\
3.500\end{array}$ & $\begin{array}{l}16.250 \\
17.875 \\
20.500 \\
24.500\end{array}$ & $\begin{array}{ll}17 & \\
18 & \\
20 & 3 / 4 \\
25 & 1 / 2\end{array}$ \\
\hline
\end{tabular}

${ }_{\text {All dimensions in inches }}$

Table 11. Common Bit Sizes ${ }^{a}$ (Blum).

\begin{tabular}{lllll}
\hline $\begin{array}{c}\text { Casing } \\
\text { OD }\end{array}$ & $\begin{array}{c}\text { Coupling } \\
\text { OD }\end{array}$ & $\begin{array}{c}\text { Recommended } \\
\text { Clearance }\end{array}$ & $\begin{array}{c}\text { Minimum } \\
\text { Hole S1ze }\end{array}$ & $\begin{array}{c}\text { Minimum } \\
\text { Bit Size }\end{array}$ \\
\hline $33 / 4$ & 6 & $73 / 4$ & $95 / 8$ & $133 / 4$ \\
$37 / 8$ & $61 / 8$ & $77 / 8$ & $97 / 8$ & 15 \\
$41 / 4$ & $61 / 4$ & $81 / 2$ & $105 / 8$ & $171 / 2$ \\
$45 / 8$ & $63 / 4$ & $85 / 8$ & 11 & 22 \\
$43 / 4$ & $73 / 8$ & $83 / 4$ & 12 & 23 \\
$55 / 8$ & $75 / 8$ & 9 & $121 / 4$ & \\
\hline
\end{tabular}

${ }^{a}$ All dimensions in inches 
minimum casing size that will allow the $97 / 8 \mathrm{in}$. bit to pass is $103 / 4$ in. Therefore, the surface casing will have a $103 / 4 \mathrm{in.}$ OD and the hole size for that casing will be 15 in. (Table 10 and 11). Although conservative, this design is believed to be reasonable. Selection of casing grade, weight, and type are not discussed at this point, but the selection of materials for tubing and casing is briefly considered.

Because the waste will be neutralized prior to injection, a system of carbon steel might have an adequate life. However, an additional investment of approximately $\$ 1.00$ per foot for plastic-lined tubing would minimize the potential for corrosion. Other components, such as the packer, the lower few joints of casing, and the liner exposed to wastewater could be constructed of alloys, plastic, or fiberglass, with the remainder of the casing being carbon steel.

\section{Cement}

The annulus between the rock strata and the casing is filled with a cement grout, to protect the casing from external corrosion, to increase casing strength, to prevent mixing of the waters from different aquifers behind the casing, and to forestall travel of the injected waste into aquifers other than the disposal horizon. Neat portland cement (no sand or gravel) is the basic material for cementing. Additives are available that give increased cement resistance to acid, sulfates, pressure, temperature, and shrinkage. Epoxy cements that are particularly resistant to corrosive chemicals are also available. Temperature logs, cement logs, and other welllogging techniques can be specified to verify the adequacy of a cementing job. Cement can be pressure-tested if the adequacy of a seal is in question. Additional discussion of these methods is given later in this chapter (IV.C.).

\section{Well Head Controls}

Figure 27 is a schematic drawing of a typical wellhead assembly or "Christmas tree." The wellhead assembly supports the tubing to allow regulation of flow and shutting in of the well, to give access to the annulus, and to permit monttoring of tubing and annulus pressure. Several manufacturers offer wellheads and the instrumentation for their control. Wellheads avallable off the shelf are probably sultable for injection of LLAW.

\section{System Operation}

The operating program for an injection systam should conform to the geological and engineering properties of the infection hortzon and the volume and chemistry of the waste fluids. Injection rates and pressures must be considered fointly, since the pressure usually depends on the volume being infected. Pressures are limited to values that do not damage well facllities or the confining formations. The maximum bottom-hole injection pressure is commonly specified on the basis of well depth. It may range from about 0.5 to $1.0 \mathrm{ps} 1$ per foot of well depth, depending on geologic conditions, but seldom ls allowed to exceed about $0.8 \mathrm{psi}$ per foot of depth.

Experience with injection systems has shown that an operating schedule which includes rapid or extreme variations in infection rates, pressures, or 


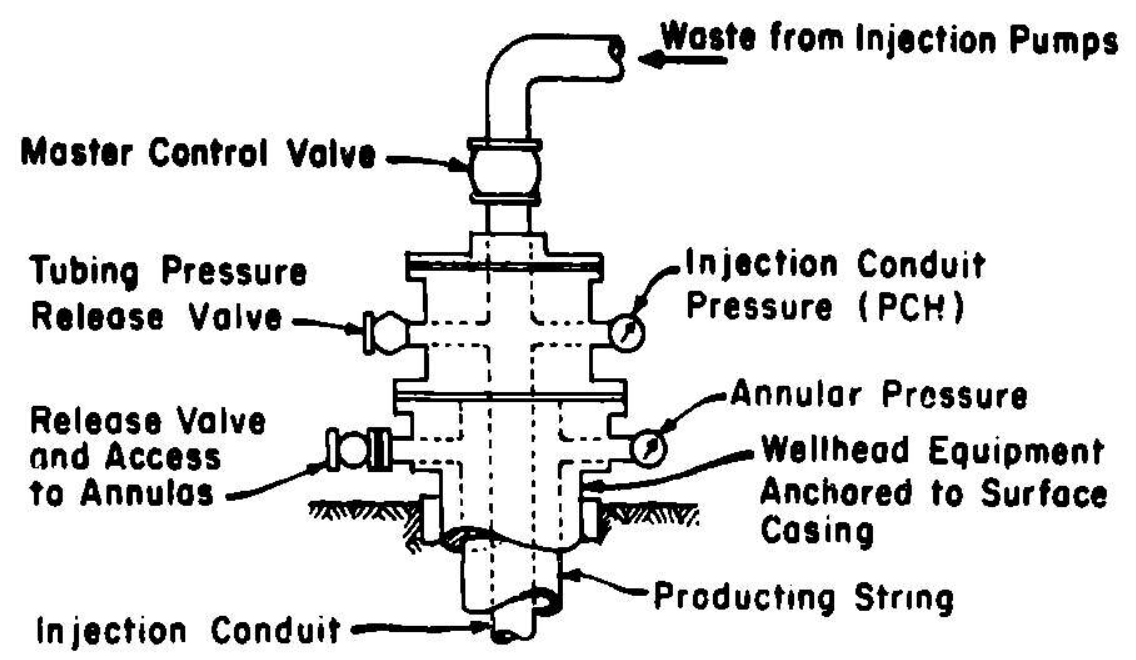

Fig. 27. Schematic Drawing of the Wellhead Assembly for a Typical Injection Well

waste quality can damage the facilities. Consequently, provisions should be made for shutoff in the event of hazardous flow rates, pressure, or waste quality fluctuations.

An aspect of injection well operation that has perhaps received insufficient emphasis is the desirabllity of periodically inspecting or testing the subsurface factlities of injection wells. Enough incidents have occurred in the past to prove the need for such periodic inspection and testing. One such Incident was the rather spectacular failure of a wastewater injection well at the Hammermill Paper Company in Erie, Pennsylvania (Piper). In that instance, the well casing parted as a result of corrosion and a portion of it was reportedly lifted from the hole by fluid pressure. There was substantial loss of wastewater into Lake Erle, and the well was abandoned. Other cases have been reported in which portions of tubing or casing have failed as a result of corrosion and have caused temporary or permanent shutdown of a well. Examination of the wellbore to check for the location of zones of wastewater entrance, enlargement due to chemical reaction, the location and orlentation of Induced fractures, and bulldup of precipitates of filtered solids may also be desirable. In a few examples, wells have been abandoned or modifled because of borehole enlargement that has led to collapse of the borehole or damage to the casing or cement near the bottom of the casing string.

Methods of periodically inspecting casing, tubing, cement, and wellbores that have been used in injection of industrial wastewaters are described below. Since system integrity is important for minimizing the environmental impact of the infection of LLAW, such inspection procedures would also be expected to be adapted to this operation.

1. Pulling of tubing and visual or instrumental inspection,

2. Inspection of casing or tubing in place, using magnetic logs,

3. Inspection of casing, tubing, or the wellbore with caliper or televiewer $\log s$, 
4. Pressure testing of casing,

5. Inspection of casing cement with cement bond logs, and

6. Inspection of casing, cement, or the wellbore with injectivity or temperature profiles or other appropriate logs.

Mechanical methods are available for inspectirg lined steel tubing for flaws in the lining. Individual joints of tubing can be pressure-tested at the surface (after pulling) for leakage.

Magnetic down-hole casing or tubing inspection services are provided by oil-field service companies. These logs indicate the relative pipe thickness by virtue of the electromagnetic response of steel pipe. Thin areas may indicate corrosion or $o$ ther damage. If such a $\log$ is performed early in the life of a pipe, interpretation of logs run after the well has been in operation is simplified.

Caliper logs provide a record of the inside diameter of pipe or borehole walls and may show intervals of pipe corrosion, borehole enlargement, or borehole plugging at the formation face. Figure 28 shows portions of a caliper $\log$ run before injection and run again after 5 yr of injection of an acidic. wastewater into a limestone aquifer. The log indicates considerable borehole enlargement as a result of dissolution of the limestone by the injected acidic waste in the interval from 1500 to $1600 \mathrm{ft}$. It would be reasonable to conclude that most of the wastewater entered that incerval.
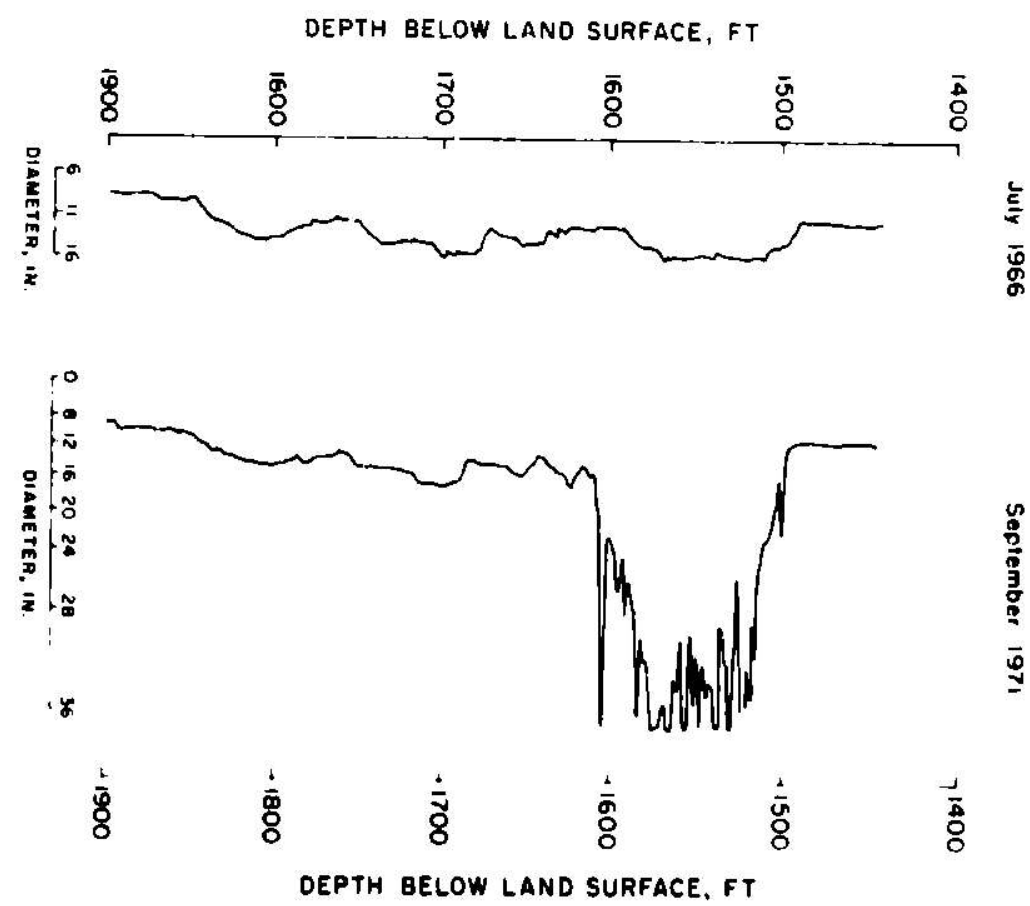

F1g. 28. Preinjection and Postinjection Caliper Logs from a Wastewater Injection Well at Belle Glade Florida, Showing Dissolution of LImestone Aquifer in the 1500-1600 foot Interval by Acidic Wastewater (Black 1972). 
Borehole televiewers provide an image of the pipe or borehole wall as produced by the reflection of sound waves emitted from a sonde. The combination sound source and receiver is highly directional and is rotated rapidly as the tool is moved up the hole. Thus, the hole is continuously scanned. The resulting information is displayed on an oscilloscope and a film is made of the scope display. The picture obtained depicts the wellbore as though it were spift open and laid out for inspection.

Pressure testing (used to detect casing leaks) is required at che time that the casing is cemented into the borehole by law in many oil producing states. In such tests, a cement plug is left at the bottom of the casing during cementing and is allowed to harden. The interior of the casing is then subjected to a specified amount of fluid pressure $(0.2$ psi per foot of casing in Texas for example). A rapid decline in pressure indicates leakage from the casing. Such a test could also be performed periodically in operating wells by setting temporary plugs or by using packers.

The cement bond $\log$ is used to determine the quality of the casing-cement bonding and to detect damage to cement from high-pressure injection or chemical reaction. The cement bond $\log$ provides a continuous measurement of the amplitude of elastic waves after they have traveled through a short length of pipe, cement, and perhaps formation (Fig. 29). The amplitude of the elastic wave is at a maximum in uncemented casing and is less as the degree of bonding and the integrity of the cement improves. Some complications, however, can arise in interpretation of observations (Fertl).

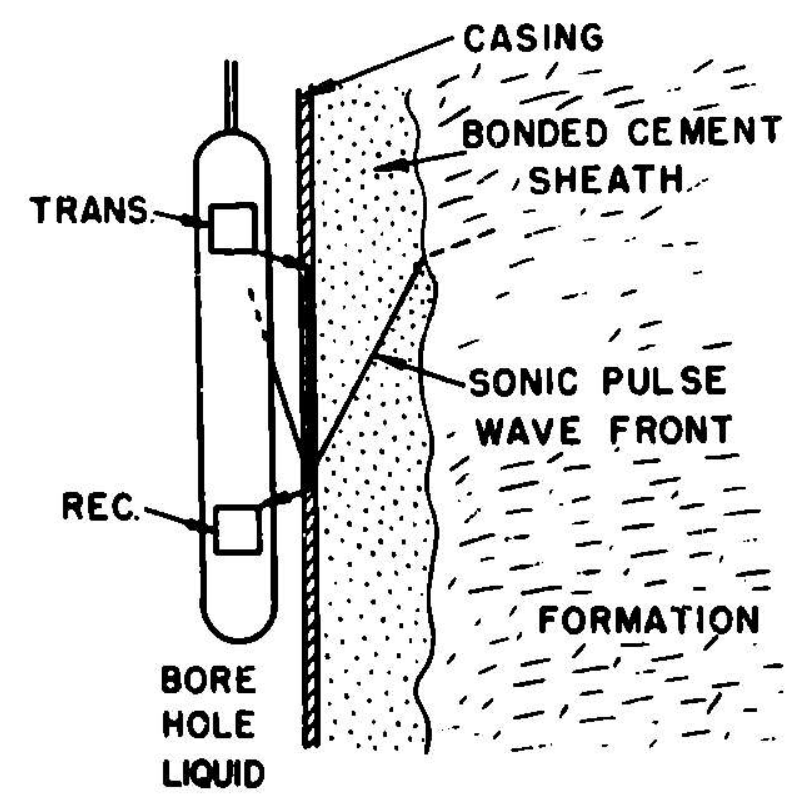

Fig. 29. Schematic Diagram of a Cement Bond Logging Tool in a Borehole (Grosmangin).

Other possible inspection methods include radioactive tracer infectivity profiles, flowmeter infectivity profiles, and temperature profiles. The objective of these methods is to determine where infected fluid is going. Radioactive tracer infectivity proflles accomplish this by irfection of a 
radioactive tracer and logging of the borehole with a gamma ray detector. The detector measures concentrations of tracer, which indicate paths of tracer flow. Flowmeter injectivity profiles are similar, except that flow paths of injected fluid are indicated by a flow meter rather than by an injected tracer. Temperature profiles may indicate anomalies at points where injected fluids enter the receiving formation or where they escape through casing or tubing leaks. Such anomalies would obviously be most likely to be detectable in wells where significant temperature contrasts exist between injected fluids and the aquifers.

Repetitive running of resistivity or radioactive logs may also be used to locate the zones that are accepting injected wastewater. Resistivity logs are limited to the uncased portion of a well, but radioactive logs have been used to locate a fresh water-saline water interface behind a casing (Keys 1973B).

\section{Monitoring}

\section{Monitoring at the Injection Well}

The principal means of surveillance of wastewater injection in present practice is monitoring at the injection well of the volume, chemistry, and biology of the injected wastewater and of the well-head and annulus pressures (Fig. 26). This procedure may seem inadequate because it includes no actual measurement of the rate or direction of waste moveruent. However, if all of the necessary evaluations have been made during the planning, construction, and testing of the well, this may be a satisfactory program when combined with periodic inspection of surface and subsurface facilities. This contention is based on the view (Talbot) that the greatest risk of escape of injected fluids is normally through the injection well itself, rather than from leakage through permeable confining beds, fractures, or unplugged wells.

Monitoring of the volume of injected wastewater permits the distance of wastewater travel to be estimated, pressure data to be interpreted, and a permanent record to be established of the volume of emplaced wastewater. A record is required as evidence of compliance with restrictions imposed by regulatory authorities. Because records may be used for interpretation of the pressure response of injection wells, continuous recording equipment should be used, and periods of shutdown noted.

The chemistry of injected wastewater is monitored as evidence of compllance with operating regulations, for interpretation of well behavior, and as a precaution in the event that a chemlcal parameter should deviate from design specifications. Some characteristics that have been monitored continuously are suspended solids, $\mathrm{pH}$, conductance, temperature, density, dissolved oxygen, and chloride residual (when chlorine has been used to control formation of microorganisms). Complete chemical analyses are frequently made on composite or grab samples. Because bacteria may have a damaging effect on reservolr permeabllity, perlodic blological analysis of some wastewaters may be desirable to ensure that organisms are not being introduced.

Infection pressure is monttored to provide a record of reservoir performance and as evidence of compliance with regulations. Infection pressures are limited to prevent hydraulic fracturing of the injection reservolr 
and confining beds, or damage to well facilities. As with flow data, infection pressure should be continuously recorded.

Perlodic infectivity tests involving observations of the decline of water level in a well with time can be done to compare the performance of the reservoir with its original condition.

Possible causes of deviation from the ideal response are the presence of hydrologic barriers or cundults, leaky con'ining beds, and permeablilty reduction as a result of zuspended solids, chemical reactions, ctc. Because a varlety of factors may Influence well behavlor, an accurate, detailed well history should be maintalned so that the probable cause of any unusual performance can be deduced and the appropriate action taken.

Pressurs: in the cas ing-tubing annulus is monitored to detect any changes that might indicate leakage through the injection tubing or the tubing-casing packer. When a packer is used, the casing-tubing ennulus pressure should remain at a selected applied presesre, except for pressure fluctuations resulting from expansion of the injection tubing. A significant change in the annulus pressure is an Indication of leakage.

other methods of monttoring the infection well also deserve mention. The corrosion rate of the well tubing and casing may be monitored by corrosion coupons inserted in the well. A conductivity probe may be used to detect a change in the chemistry of the fluid in the casing-tubing annulus. In wells with packers, a conductlvity probe can be used to detect tubing leaks. Another technique that has been used to monitor the caqing-tubing annulus is continuous cycling of the annulus fluid and analysis of the return flow for evidence of contanination by wastewater.

\section{Monitor Wells (Separace from the Infection Well)}

The subject of monitor wells has been a contruversial one in regulation of wascewater injection. Such wells are routinely used in shallow groundwater studies, but are less frequently used in conjunction with wastewater injection, for reasons that will be examined.

At least three hydrogeologically different types of mitor vells can be and have been constructed, each with different objectives as shown in Table 12.

Monitor welle constructed in the recelving aquifer are normally nundlschargling because a discharging wonltor well would defeat the purpones of the injection well. Als?. the brines produced would have to be disposed of. Normally it to not necessary to monitor preseure in the receiving aqulfer except at the Injection vell. However, epecial onitor wella ay be desired where pressure at a distance froo the injection well 18 of concern becaume of the presence of known or suspected faulte or abandoned wolle that any be Inedequetely plugsed. The prosesure rusponse in anitor well at such locations vould indicate the extent of danger of flow through such breachee in the confinlng beds and possibly would aleo indicate whether leakage vas occurring.

Constructing a conltor vell or wells in the recelving equifer 1 e the only diroct anane of verifylng the rate and direction of vastewater 
Table 12. Monitor Wells--Types and Objectives

Well Type Objective

1. Constructed in the receiving aquifer--nond Ischarging

2. Constructed in or fisst above confining units--nondischarging

3. Constructed in a freshwater aquifer above the recelving aquifer
A. Obtain geologic data

B. Monttor pressure in receiving aqulfer

C. Determine rate and direction of wastewater movement

D. Detect geochemical changes in infected wastewater

E. Detect shifts in freshwatersaline water Interfaces

A. Obtain geologic data

B. Detect leakage through confining undt

A. Obtain geologic data

B. Detect evidence of freshwater contamination 
movement. Frequently, more than one well is necessary to meet this objective, because nonpumping monitor wells sample only wastewater plumes that pass directly through the inonltor wellbore; nonunlformity of aquifer porosity and permeability can cause the wastewater to arrive at a particular well very soon after injection or sometimes not at all. A single well might be satsfactory where aquifer and flufd propert les are such that (1) it is judged (although this is most unlikely) that wastewater movement will be radial and reasonably uniform or (2) the objective is to detect wastewater arrival at a particular point of interest.

Negative factors that should be considered in any case where deep monitor wells are contemplated are as follows: Monitor wells in the receiving aquifer may be of $1 \mathrm{imj}$ ted usefulness, and they provide an additional means by which infected wastewater could escape from the receiving aquifer.

In a number of cases, multiple wells have been constructed at a site, one or more of which were standby injection wells. Standby wells can be used for monitoring aquifer pressure and for sampling aquifer water. However, their operation or extensive testing wight alter the character of the formation water sufficiently to malse it difficult or impossible to detect the passage of the wastewater front, impairing their use for monitoring.

For the detection of leakage, the principle of using nundischarging monitor wells completed in the confining ieds or in a confined aquifer immediately above the conf Ining beds has been widely discussed but has been little used. This type of well has the potential for acting as a very sensitive indicator of leakage by allowing small changes in pressure (or water level) that accompany leakage to be measured. A well of this type is best used where the confining unlt is relatively thin and well defined and where the engineering properties of the two aquifers are such that pressure response in the monitored aquifer will be rapid if leakage occurs. Concepts have been out lined that will allow evaluation of the possibllities of success of this monitoring method in a specific situation (Witherspoon 1972). In many cases, conf ining beds are several hundred to several thousand feet thick and do not contaln aquifers sultable for such monitoring. In other cases, the physical circumstances are amenable tu such monitoring, but several thousands of feet of interbedded aquitards and saline water aqulfers are present; in these cases, slow vertical leakage across the aquitard immediately above the injection interval is not algnificant because it can be predicted that there will be no measurable influence at the stratigraphlc level where fresh water or other resources occir.

Two good examples of the usefulness of monitoring an aquifer lmadiately above the conf Ining beds have been described recently. In one case. wastewater leakage from the lower florldan aquifer through $150 \mathrm{ft}$ of confining beds Into the upper Florldan aquifer was detected by analyais of water from a wonitor well constructed in the upper ploridan aquifer (Kaufaan). No prew-ure effectw were not iced in this instance. In another case, leakage through the confining bede firet was detected by a pressure Increase in an overlylng aquifer and later was conf Itand by chenical analyels which ohowed contanination of water in the equifer (Leenheer).

The type of monitor well wot comonly is use ts that which is sompleted In a fresh water aquifer above the infection horison for detecting 
fresh water contamistel ion. In a number of locations, thls type of ariftoring is provided by we!ls that a:e a part of the plant's water supply systen. In other cases, the wells ha ig been conserucced speciflcally for monitorlig and are nut used for water supply. Wells for detection of fresh-water conciaminat lon should be dischirging wells because they then sample an area of aquifer within their cone of depressiun. As previuusly mericloned, nondischarging wells are of linited value for detection of contamination because they sample only water passing through the wellbore. Hells for monituring fresh-water contamination should be located close to the anticipated sources of cuntaminat lon, whlch are:
1. The injection well itself,
2. Other neiliby deep wells, active or abandoned,
3. Nearby faults or fracture zones.

The preceding discussion Inplies that separate vells should be cunstructed for survelllance of aquifers and aquicludes at different depths. This is not necessarily the case (Talbot) since the injection well 1 tself can be adapted for monitoring overlying aquifers, and bccause a monitor well may be constructed for survelllance of wore than one aquifer. One Injection well was modified for monitoring two aquifers overlying the irjection zone (Hilson).

\section{Other Monlturing Possiblitties}

A method of monitoring not ment loned above is the sampling of uprings. struams, or lakes that could be affected by injection. There are few Instarices where such monitoring vould be applicable; however, an example of such an Instance is a opring that originates along a fult within the ared of presure Influence of the injection vell. An increase in discharge rate or change in water quality could be an Indication that format ion water is leaking along the fault in response in the increased pressure from injection. Also, springs and gaining steams" ace isllarly to discharging velle in providing a cowposite saaple of groundwater over thelr aras of influence; thus, they of ght reveal that leakage 18 uccurring from unknown fracture zones or abanduned wells that connect a shallow groundwater aquifer with the injection interval. In a imilar vay, lakew aly be collecting points for grounduater seepage or -treams, and sapplou of lakewater ay reflect quality changes in shallow groundwater aquifern.

Surface seophyelcal ethode offer linited poselbilleles for eonltoring wasteveter injection. The feesibllity of conttoring the diseribution of infected wastewater with selendc reflection hes been sugeseted (bart). Monitoring by

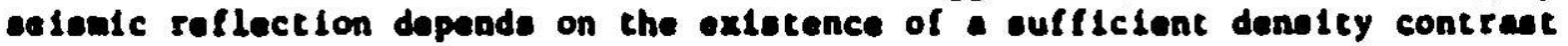
between injected and interetitlal vater; no fleld triele of the cechalque have been reported. Electrical realetivity eurveying could be usefil for conltoring the eovecont of frach vater-eeline vater interfaces or for detecting sellne water pollution of (resh-uater equlfere (Swartz, Harner 1969).

$$
\text { Monteuring for uarthquake occurrance is accueplished by a necwork }
$$

\footnotetext{
A gaining etreas in one whose fliw le belng supplesented by grounduacer flow froe en ad jacent equifer.
} 
of seismometers placed in the viclnity ": the infectlon well and in the vicinity of nearby faults along which seismic events might be eriggered (Raleigh, Haniy). In a zase where earthquake selmulation is consldered a possibility, geigw!c monftoring to obtain background data should begin berore the well is operated.

Finally, monlcuring the infection of LLAW would be facllitaled by the possibility of using radioact ive count ing techniques. Many of the trit lum monitoring techniques (Budnitz) diveloped for aurvelllance of reactor streams should be applicable co monitoring subsurface movement of LLAW. The potential for detect Ing excess levels ot tritlum $1 \mathrm{~s} \mathrm{high}$. The lower limit of detection In aqueous liquid is about $\& \times 10^{-7} \mathrm{HCl} / \mathrm{ml}$ (Moden). whereas the radiation concentrat ion guideline for public exposure is $3 \times 10^{-3} \mathrm{wCl} / \mathrm{ml}$.

\section{v. I.EGAI. AND REGULATORY CONTROLS}

A. Importance and Present State of Applicable Laws and Regulat ions

Legal and regulatory requiremen's may prove to be his most furmidable barter to putting into practice the disposal of LLAW ty deep-well infection. The development of laws and regulations alaed at controlling deep-well injection has grown in recent years. Furthernore, interpretation and implementition of these laws and regulation are st11l in the process of eacrence and evolution. Therefore, It ls not possible tu succinctly describe a general set of regulatione that would apply to injection of LLAW within the U.S. The nature of regulat ions applying to construction and operation of a vell for LLAW diaposal would vary with the state where it is to be lucated and with the nature of neu federal regulations expected to appear.

In epite of the present uncertainties in regulatory requirements, it is posstble to exanine quet ions such as which sgencles will be involved in the legal and regulacury control of well operation, and the aspects of operation that these regulations and 1 wa a re likely to concern. It in expected that the liceneing and regulat ing procese vill consist of a sequence of stages, each involving governmental review and peralesion to proceed. These ntages wll probably include requeste for peraibeion to conetruct, to test, to begin injection, and, perlodically, to continue operation.

\section{B. Arencles Likely to Regulate Injection of LLAW}

For the Injection of LLAW, It can be assund that NRC would be Involved In 11 pheses of the liceneing and regulation because of the radioactive nature of the LLAW and lte origin in a fuel-reproceseing plant (which type of facility is Ilceneed by the MRC). For the Injection of Honradioact (ve wastes, an agency of the state In whlch the weid is to be operated has tradiclonally been the prise regulacory body. It le expected that atates having an adequate regulatory etructure with reapece to disposel velle would share with NRC the regulation of vell Inject Ion of LLAH. The federal egency concerned with deep-well Injection of nonradloactive waetes Is the EPA. The authorlty of the EPA In regulation of disposel wells, hower, had not been clearly opectfiud until Publlc Law 93-523 was recen:ly paseed (Dececber 16, 1976). Th1s lew, known as the Safe Drinking Water Act, contalne provielons for the regulat lun of vaete injection velle by the EPA, and enjolne that agency to publish vithin 180 days of 
the passage of the act a set of "proposed regulations for state underground Infection control prograns" (Sf c. 1421). Formerly, federal authority to $r$ gulate waste injection wells seemed to be justifled mainly by liberal interpretation of the Federal water Pollut amendwent of 1972 to the federal Water Pollution control Act. The power of the EPA was assumed to reside in the abllity to restrict the particlpation in the Nat tonal Pollutant Discharge Elimination System (NPDES) and associated federal funding programs of any state that did not teet requirements related to water quality including the adequate regulation of waste infection wells. The EPA alou issued a pollcy statement, referred to as Aministrator's Decision Statement Number $b$, (hereafter ADS 15 ), * Intended as a set of guidelines for state regulatory control of wiste injection.

In addition to the increased Involvement in the regulation of waste disposal wells recently charged to the EPA $b$ : the Safe Drinking Water Act, the EPA may also he required to participate. in regulation of any discharge of radioactive wastes Into natural waters, through a Colorado Courts decision of December 1974 (Nucleonicy Week). This decision wight be interpreted as charging EPA with rusponsibilities that overlap thuse of NRC in many cases, a situation that led to reports that NRC would contest the decision. If the original decision and the above interpretation prevail, EPA might be involved in all phases of regulation of an Injection of LLAW. In any event, It Is assumed that EPA would particlpate at least in the inltial phases (e..., review of the application for a well).

Although the U.S. Geological Survey (USGS) does not have a regulatory responslbility in the speclfic aroa of operation of deep-well injection, it has cooperated in the past with the U.S. Atomic Energy Comission in evaluating the geologic and hydruloglc problems related in general to the geologic storage of radluct ive waste (DeBuchananne). Also, it has been instrumental in the exchange of information on deep-well injection of radioactive wastes and in the role of sponsors of various studles and cosponsor: of two conferences on underground waste managesent (Braunstein, Cook). The USGS would therefore probably particlpate in the review of any applications for permisston to disposic of I.LAW by deep-well injection but would probably not particlpate in regulation.

it is concluded therefore, that the initial stages of a pruject involving duep-well injection of LLAH (i.c., applications for perminsion to construct, to test, and to begin injection) alght be revicwed by representatives of four bodiea, the state, the NRC, USCS, and EPA. The regulation of uperation, hovever, would be expected to be carried out by the state, by NRC, and possibly by EPA, depunding on further legal developients.

Alth wgh the reguljiury piscese- that would apply to the Injection of LLAH Is not fire at this ties, It is poselble to anticlpate sone aspects of the nature of contribut lons of each of the agencies listed above to the regulation of such a well by exanining the type of policles that each agency has act forth In the paet.

Reproduced In Appendix E of thle documant 
The first agency considered is : IRC. Although it has not published a policy specifically directed at deep-well infection $c \xi$ wastes, its anticipaced role in regulating a well for injecting LLAW can be generally lllustrated by the process which has envolved for the licensing of nuclear facilities.

\section{The Federal Process for Licensing Nuclear Fac1lities}

L. Assumptions and Considerations Related to Licensing an Injection Wel1

Application to install an infection well at a fuel-reprocessing plant after the plant has been constructed and licensed for operation would probably be subjected to preliminary review by NRC, the state involved, EPA, and USGS. This pieliminary review could result in permisolon to construct the well or in a recomendation to delay construction pending treatment of the profect by the detalled process which has evolved for licensing of construction and operation of nuclear facilities. On the other hand, if an injection well is installed at a nuclear fuel-reprocessing plant as a part of the initial plant construction and operation, it 1 ; assumed here that thr review and regulation of the well would be treated as a part of the whole fac lity in the detalled licensing process. In order to illustrate the federal licensing prosess, excerpts from a description of the process (Buchanan) are inclucied below. The description is recent, but it was written before the reorganization of the federal energy effort and may therefore be subject tu change as the policies of ERDA and NRC evolve. Although the description was directed mainly at the licensing of reactors, it is presented here with the assumption that the general aims of each stage of the process would be the same in licensing fuelreprocessing plants and related facilities.

\section{Informal Site Review}

Applicants are encouraged to discuss informally the possible sites with the Regulatory staf before filing an application for construction. This preliminary discussion provides the applicant with guldance on the acceptability of the sites and with information that must be included in the application for construction. In an environmental report, the applicant must compare the merits of several possible sites.

Factors considered in judging the acceptability of proposed sites Include: dimensions; site characteristics (e.g., seismology, meteorology, geology, and hydrology); population density in the area; and uses of the surrounding area (e.g., Industrial, farming, and residential). The importance of selamology, geology, and hydrology in choosing a site for injection of LLAW was discussed in detall previously (III.B., III.D.); Information on the population density and uses of the surrounding area would be useful in determining the potential environmental lopact of possible maloperation (Section VI).

\section{Aaplication for and Preliolnazy Review of a Construction Permit}

As a major part of the application for a conistruction permit, the applicant files a Preliminary St.fety Analysis Report (PSAR), presenting the design criterla, preliminary drsign information, and comprehensive data on the proposed site. The report also discusses hypothetical accident situations and the safety features that w11l be provided to prevent accidents or, if accidents should occur, to mitlgate their effects on both the public and the 
employees of the facllity. In addition to the application and PSAR, a separate document, entitled "Applicant's Envirunmental Report--Construction Permit Stage," must be submitted to comply with the requirements of the National Environmential Policy Act of 1969 (as delineated in the Code of Federal Regulations, litle 10, part 51, April 30, 1975).

\section{Technical Review by Regulatory Staff}

The Regulatory staff reviews a construction permit application to determine if public health and safety will be fully protected. If any portiun of the application is considered inadequate, the Regulatory staff requests the applicant to modify the plans. The principal features of the Regulatury staff's review include:

1. a review of the populat ion density and use characteristics of the site environs and the physical characteristics of the site,

2. a review of the design, fabrication, construction, testing, and expected performance of plant structures, systems, and components important to safety,

3. evaluation of the response af the facllity to various anticipated operatiny: transients and to hypothetical accidents.

4. a revlew of plans for plant uperations, including the organizational structure, the technical qualificat lons uf operating and technical support personnel, the measures taken for Industrial sccurlty, and the planning for emergency actions, and

5. evaluations of the design of the systems provided for control of the radiological effluents from the fillity.

5. Public Hearing on Construction Permit

A public hearing to consider issuance of a construction permit is scheduled. This hearing considers both safet, and environmental lasues; public notice of the hearing date is published 30 days in advance in the Ficicis: Rejist, $r$. In addition, a public announcement is issuad to the news media in the vicinity of the site.

At the the of their losuance, the Regulator: otaff's safety-cvaluation report is made avallable to the public. Coples of the evaluations are also furnished to state and local officials a.d to newspapers in the area.

The public heuring usually is conducted by an Atomic Safety and Licensing Board (ASLB) uppointed by the Comission or by the chatroan of the ASLB panel. The applicant's test lmony consists of the application itself. any flled awendments to it, and any other pertinent documents. The Regulatory staff's testimony consists of the safety-cvaluation report and lts supplement. Regarding environmental maters, the applicant's environmental report and the NRC's final environantal stutement are presented.

In a hearing for a conatruction permit, the ASLB deteraines whether the application and the record of the proceeding contain eufficlent information. and whether review of the applicat lon by the NRC. Regulatory otaff has beun 
adequate. For a contested hearing, the ASLB also considers the cuntentions and testimonies of Intervening parties.

The ASLB considers all evidence presented, cogether with findings of fact and conclusions of law filed by the parties, and issues an lnitial decision. If the intelal deciston is favorable, a construction permit is issued by the Director of Licensing. If an exception is tiled by any party, the initial decision is subject to review by an Atomic satety and Licensing Appeal Board or by the Commissioners upon their uwn mution or upun il Ing a petition for review.

\section{Review of Applicat ton fur Operat ing License}

When final design information and plans for opuration are ready. the applicant submits the final safecy-analysis seport in an application for an operat ing license. The information includes plans for operatiun, procedures for emergency situations, and details on the final design. Once again, the NRC Regulatory staff makes a detalled review of the information on the plant. Amendments to the application may be submitced from time to time for review by the Regulatory staff. The Regulatory staff prepares a safety-evaluation report regarding the operat ing 1 icense.

A public hearing is not required by law on an application for an operating license. Normally, the Commisston will not hold a hearing it this stage unless there is substantial public interest in it or if a hearing is requested by a party or person whose interest would be affected. If no hearing is scheduled, a published notice states that, in the absence of a petition to intervene and a request for a hearing, the license will be issued. If a public hearlng 18 held, the same deciston process described for the construction permit hearing 18 applicable.

Each license for operation, usually issued for the design Iffe of the facility, contains technical specificotions of measures for afety and environmental protection and the conditions of its operation.

\section{The Federal Inspection Program}

The Regulatory staff Inspects as necessary to ensure that the Ilcensce Is carrying out its responsibllity. The on-eite Inspection program has three objectives:

1. Tu detervine the effectiveness of the quality-assurance program.

2. To determine the soundness of construction, aupporting functions. procedure development, and training.

3. To determine whether the licensee is operating in coupliance with the proviulone of hls licenes, with the rules and regulatione of the NRC, and with the Atonic Energy Act.

Nuclear facilit tes are inepacted during conetruction, preoperational teat 1.as, etertup testing, and routine operation. Typlcally, facility any be Inspected 25 to 30 claes during the perlod of construction. Enforcent ect on to taken on all ident 1 fled noncompliance and eafecy atcera. Enforcement actione can range from notices of vlolat lon to ordere for supending or 
terminating a license.

The lechnical specifications of the license require the operiator lo ille periodic reports describing the operation of the facility. The operator is also required to filc reports of abnormal accurrences ur incidents. These reports are reviewed to determine that operations are being conducted safely and within the license conditions.

\section{The Role of State Agencies in Decp-Well Injection wi Wasce}

For states whlch have a regulatory program for control of deep-well injection which is adequate by such otandards as the guidelines set forth in ADS $" 5$ and those following from the Safe Drinking Water Act (SDWA), the state is expected to be the primary regulating body. It is assumed that in a stalc. lacking an adequate program of controls the primary regulatory agency would be federal.

In the past, state control of disposal wells has varled greatly with respect to policies, liws, regulations, and administrat lve organizat ion rusponsible for regulation. At present, the state administrative organization tu control waste disposil wells usually involves one or more agencles within the state charged with responslhllity for health, water quality, environmental protection, or natural resources. It is expected that an eventual effect of ADS 15 and the SINA will be an approach to more uniform state control systems, at least with respect to a minimum level of control. The spectrum of state controls will probably tall into three broad categories: those that prohibit dispusil wells, those that allow disposal wells and follow EPA guidelines as a mininum control posturc, and those that allow disposal wells and have a compreliensive set of regulations that are more strlet than EPA guidelines.

The general climate of regulatory control that would conf ront any pruposal to inject LLAW in any state can be only surmised from infurmation now dvallable un state regulatury procedures; the climate may change as the interpretation and adiptation of SIINA and ADS is begin to play a role.

In general, states have controlled waste infection by laws, by administrative regulation, and by pollicy statements. States allowing waste injection have fallen into two broad categorles--those having comprehensive laws and minor regulations and thuse having general laws but detalled sets of regulations.

Four elements are common to many beis if state contrul provisions (Cox):

1. Prellainary Feasibility Analysis--Michigan's statement on prellminaty fonstbillty analysio is an example of a comprehensive set of specificat lons. These epeciflcatlona involve consideration of permisulon of adjacent landowners; other wells in the area; topography; demography; locat ton of potable water in the area; mineral resurces: geologlc otructure and etrat igraphy; waste characterlstics; putentiooutrlc eurfaces of aquifers; voluse, rate, and pressure of Infection; chenical, geologic, and physical charactor of the injection interval: and a nuber of types of ongincering data on the construction and operat Ion. 
In most cases, the preliminary feasibflicy allalysis must foldude a cotopartson of the composition of the native fluid in the inconded recelving aquifer with the specification (by the particular state) of the lower limit for dissolved sollds concentration in llitive fluids. These requirements endeavor to protect tresi-water and potentially useful brackish water by prohiblcing waste discharge into all water whose quality exceeds certain levels as indicated by speciffe quality parameters (usually chlorlde or cotal dissolved solids content). In New York., uses of groundwaters lncluding ialine ones have been classified on the basls of quallty. Fresh groundwaters are def Ined as those having a chlorlde concent equal co or less than $250 \mathrm{mg} / \mathrm{l}$ or a total dissolved solids cintenc equal to or less than $1000 \mathrm{mg} / \mathrm{l}$. Saline water is def ined as water exceeding chese limits. Saline groundwaters are classified as GSA or GSB. CiSA waters are those best used as a source of potable mineril water, for converston to potable water, or as raw materlal ior chemlcal manufacture. CSB waters are those saline waters having a chloride content in excess of $1000 \mathrm{mg} / \mathrm{l}$ or a total dissolved sulids concent of over $2000 \mathrm{mg} / 1$. the aquifers of which may be used for disposal of wastes. Nebraska regulations require that the concentration in the disposal zone be at least $5000 \mathrm{mg} / \mathrm{l}$ total dissolved solids. The Texas Water Quality Board considers all water having a total dissulved mineral concentration between 3000 and $10,000 \mathrm{mg} / 1$ to be potentially benefletal. Illinols and Mississippl also protect all water having a cotal dissolved solids content of less than $10,000 \mathrm{mg} / 1$. The unwritten guidelines usid in Alabama prohiblt waste discharges intu groundwater less saline than sea water, i.e., approximately 35,000 $\mathrm{mg} / \mathrm{l}$ total solids (Cox).

2. Requirements for Well Design, Construction, and Operation--The wide rarlation in well design required by geological varlation limits the possibllity of specifying design. The well design statencint of Nebraska has been given (Cox) as an example of one of the most detalled sets of design requirements. This set of requirements addresses such toplcs as type, length, and setting of casing and tubing; cementing, logging; rock sampling; automatic safety equipment; records; waste pretreatment; and monitoring. Other states have addressed such topics as construction materlals; pressure gradlents; emergency facllitles; qualiflcations of designers and operators; surface equipment deslgn; varlous testing procedures; and precreatment of the Jisposal zone.

3. Monitoring Requirements--The range of requirements have included monitoring of volume, chemlstry, and temperature of infected waste; pressures at the well-head, In the casing-tubing annulus, in the infection aquifer, and in the lowest fresh-water aquifers; and watcr quality in nearby fresh-water aquifers, springs, and wells.

4. Abandonment Requlrements--Factors considered in these requitements by varlous states Include plugging procedures and materials; itme perlod between ceasing operat ion and plugging: notification of agenctes and obtaining permits; depth and type of plugging: question of caning and tubing resoval; eurface markers; and conservation of resources and potable water in the area.

Prosent atcltudes of the staten toward deep-well injectlon of Induatrial wates In general are numarlzed in Table 13 whlch categorlzeg postions on 

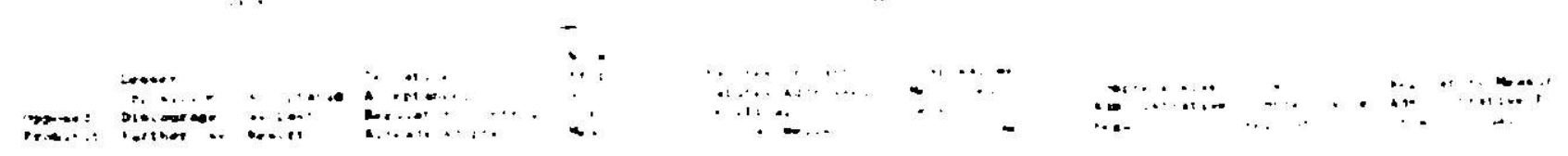

$\ldots+\cdots$

(1)

artise...

-

$\therefore$ icen

i.

19.

10.

$\therefore$ ancicerto

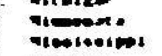

nicomeris

- $=\infty$

$\therefore=0$ "

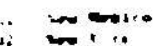

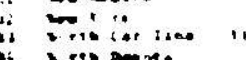

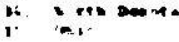

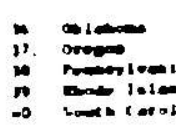

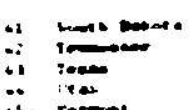

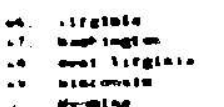

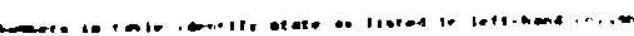


polfey, law, and regulat huss. This callegurizallon is alapted from a recent comprehenstve study of legal asperts ai deep-well waste injection (cux).

\section{L.aw:s}

The postefion on deap-well inject fon ol wasles in three of the few states that presently have ipecilic statues covering the practice cin be partially assessed from the following inturmat 1 on on thelr history and procedures.

In 190l, Texis passed the ifrst such litw, titled the "lnject fon well Act." This sitatue wos amended in 1969. The Texis act requlres a permit, which is obtalned by filling an applicallion with the Water luallty Buird. Permit applicat fons are sent for comment to the Water Development Board, the Department of Health, the Water Well Drillers board, and any other agencies or persons the Water vuailty board may designate. Public hearings on applicattons naly be held, but are not required. A letter irom the Texas Rallroald commission must be submitted with the application stating that the proposed well will nut endanger or infure any oll or gas formation. The Water quaity Board may adopt rules, regulations, and procedures to support the Injection Well Act.

Prior to 1967, Ohlo did not, by polfcy, permit the subsurface injection 0 i wastes other than ofl-fleld brines. During 1967, the onlo lcgislature enacted changes in the stille oll and gas code to incorporite specific wording pertaining to industrial-waste disposal wells. Regulatory authority is in the Division of 011 and Gas of the Department of Natural Resoirces. Applications for a permit to use a well for waste disposal must, however, also be approved by the Water Pollution Control Board, the Department of Health, and the Geological Survey. If the proposed well is in a coal-bearing area, the Division of Mines must also give approval. Denial of approval by agencies other than the Diviolon of 011 and Gas can be appealed. Requirements for construction and abandunment procedures as applied to 111 , gas, and br. te diuposal wells in Ohto generally also apply to Industrial-wiste infection wells. Such requirements include obtaining a permit to drill, reopen, decpen, plus, and to rework a well, nosting of a surety bond, providing a well complet lon report and such rock samples and well logs as may be requested, and mafutalning, a recerd of the volume of flutd inlected and the pressures experlenied.

Michigan's "Mineral Well Act" wis enscted in 1969. Il requires that a permlt be obtalined from the supervisor of mineral wells prlor to drilling, decpening, reworking, or convertlng a disposill well. Publli hearings may loc held by the supervisor if he belleves that the public saficy or interests are Involved or it he recelves a written request or petition alleging that auch conditions exlet. A woll constructed under a mineral well permit cannot be used for disposil unt 11 use has been authorized by an order of the Water Resources Commisefon. Welle operatid as disposil wells must be subjected to performance tost of some type at leist once eath calender quarter. Among the spectfle requlements for uperat lon and monlto:ing is one that states:

"Not :ess than 1 observation well, located within $100 \mathrm{ft}$ of the disposal well, shall he provided for each well used for the disposal ur etornge of ridionclive materials. An observation well slabl pellectite. as a minimum, the formational unlt immediately overlying and confining the dlsposal formation. The well or wells slatil be used for conelnuous control and munitorlng on a scale rommensurate with the level of the radloactivity." 
In a nubler of other states spectific reterence to subsurface disposal is included in the general pollution control laws. These states include Arlzona, Californta, Colorado, Conrecticut, Illinols, Maryland, Mississippi, Missour 1, Nebraska, New Mexico, North Carolina, North Dakota, Oregon, South Dakota, Vermont, West Virginia, and Wyoming. Amont: these stilte's, Nurth Carolind alin Missouri proitibit dispositl wells by liw and Virmint by administratlece order. Most of the other states in this group simply subject disposal wells to the general provistons of the pollut fon control liws. Callfornta and West Virginla include more detalled provistons.

Insofar as is knuwn, the remaining states rely on general pollution control and ofl and gals laws that make no specifle mention of industrial waste injection wells.

\section{Regulations}

Comprehens Ive administrative regulat lons applicable to injection wells have been adopted in Colorado, Hawail, Louisiana, Michigan, Nebraska, and Oklahoma. A copy of the Colorado regulations is included, in Appendix $C$ as an example of a set of comprehensive stiste regulatiuns. loss comprehensive regulations have been developed in Calffornia and Pemsylvania. Washington state regulations require that a disposal well permit be ubtained, but state that disposal wells will be authorized only under extraordinary circumstances. Disposal wells are prohlbited by regulation in Delawire and Wisconsin.

Informal but documented regulatory procedures, such as those in Illinois, may have been developed by cthrer states.

\section{Pollicy}

Statements of polfcy concerning subsurface wastewater injection have been developed on formal or Informal bases in Alabama, Florida, Kentucky, Michigan, Mississippl, New York, Penniylvania, and VIrginia."

In addilion to Individual staces concrols uver deep-well infection of waste, one interstale body, the Ohfo River Valley Water Sanitation Commis8 ion, has developed a pollicy statement (ORSANC(1)) covering the practice. ORSANCO Is an interstate compact commission representling 111 linuls, lndiana, Kentucky, New York, Ohio, Pennsylvania, Virainia, and West Virginia. A pollcy statement was agreed upon and adopted as a furmal resulution by ORSANCo in 1973. The ORSANCO polfcy and accumpanying administrative procidures are Included in Append IX $D$.

E. The Possible Role of EPA In Regulation "If II Proposed lnjection of LLAW

The increasing involvement of EPA In ropulat 10 of industrial waste wells in general and its possible rolo in regulat ing discharge of any radiu-

\footnotetext{
Much Information concerning state laws, regulatluns, and policles was provided by W. E. Cox of the Virginia Nater Resources Rewearch Center, Blacksburg, virginta. The informat ion was obtalned by the Conter during a study sponsored by the Nat Ional Sclence Foundation. It should be recognized that laws, regulations, and policies are constantly changing and that sone of the information in this chapter may rapidly be outdated.
} 
activity into natural waters in general (Section V.B.) have led to the conclusion that EPA might also be involved in regulat fon of any proposed injection of LLAW. The bases tor the probable position of EPA on such a proposal are the ADS \#j and the SDWA. The set of proposed regulations for state underground infection control programs called for by SDWA were to have been published by EPA 180 days after passage of the act (i.e., about June 30,1975). Recent information on the status of these proposed regulations (Thompson) indicates that a draft set was circulated for coments in Apr1l 1975, that 1t w1ll be extensively revised, and that it may appear in the Fedip., 2 Register in the Fall of 1975. The SDWA also adds that 180 days after publlcation of the regulations (i.e., about December 31,1975 as originally scheduled), the Administrator (of the EPA) "shall. promulgate such regulations with such modification as he deems apfropriate." Thus, the regulations may be additionally modified in the future. Information obtained from the EPA indicates that the general nature of this set of regulations will consist of a requirement that states have a control program for deep infection wells, in harmony with the general considerations of ADS $15 .^{*}$ Il 1 s expected that the forthcoming regulations and amendments w11l also enlarge upon and provide some interpretation of ADS \#5, i.e., it 18 expected that not every item of ADS \#5 will apply to every waste injection project. The text of ADS 15 published in the Federal Register is given in Appendix $\mathrm{E}$.

F. The Possible Role of USGS In Licrnsing and Regulating a Proposed Injection of LLAW

The role of USGS in any proposal to inject LLAW is expected to be most important in the preliminary analysis of feasibility, i.e., in the review of applications for construction and operating permits. The scope of the activirias of th "GGS in contributing to " solution of problems inve: iving geologic emplacement of wastes was recently outlined (DeBuchananne). These activities include locating the geologic and hydrologic environments best suited through laboratory, theoretical, and fleld investigations. The investigation efforts of USGS have been grouped (DeBuchananne) into six categories: (1) regional geologic and hydrologic studies, (2) search for environments sultable for deep storage, (3) search for environments suitable for shallow storage. (4) Identification of direction and velocity of movement or migration of waste products through earth materisls, (5) deveiopment of techniques of monitoring or survelllance in different geologic and hydrologic environments, and (6) review of natural catastrophis events and their potential impact on waste containment. The USGS can be expected therefore co evaluate any proposal of injection of LLAW or the basis if experience obtained in investigating all except the second of these categories.

\section{G. Common Law Constraints}

The iegal constraints on injection of wastes into deep wella are not IImlted to the requirements lmposed by state and federal governaents discussed in the preceding aections. An extensive examination has been made (Cox) $0 i$ the possible effect on the practice of waste injection of the system of property rights and civil law courts proceeding frow litigation by private parties. In the absence of court decisions speciflially Involving industrial waste injection, excepting salt-brine recharge wells, a number of decisions on cases that way be analogous have been examined ( $(.0 x)$.

t

The proposed regulations have been publlshed; see "State Underground Injection Control Programs, Proposed Regulat lons", Federal Reglster, Vul. 41, No. 170, Tuesday, August $31,1976$. 
The practice of waste infection could be confronted by two types of litigation, one involving the question of ownership of subsurface space and the other involving the quest ion of liablitity for injury resulting from the practice of waste infection. Moreover, there are two types of suits that might be brought against a $\mathrm{f} I \mathrm{rm}$ engaged in waste infection. One is an action seeking to remedy dalniges by restitution or compensation, and the other 18 an infunction secking to prohibit certain operations.

\section{Subsurface ownership}

The questiun of ownership of the space beneath the soll, to the center of the earth, apparently has not been setcled unequivocally. Two aiternatives are concelved; control solely hy public regulation with associated public interest limitat lons or control by a combination of direct goveramene regulations and private property rights. Some cases, decided in favor of exclusive control by the landowner, involved commercial use of natural caves, drilling at angles into adjacent property, and storage of natural gas. Other cases, decided in favor of nonownership of subsurface space, involved oil production, brine disposal, natural gas storage, and location of sewer lines.

Even if a decision were made in favor of nonownership of undergruund space, the right of state and federal governments to authorize the use of the underground for waste infection by private $f(\mathrm{rms}$ might be questioned. Thus, citizens filing suit against a government agency to contest this authority is a possibility (Cox).

In an effort to predict the outcome of Litigat Ion involving waste infection, the analogy of ownership of underground space to the ownership of airspace above the sull has been examined. The latter question has been involved in a number of court decisions, which were reviewed (Cox). It was concluded that underground space has a greater potential than alrspace for being redurs to landowner's possession and control; however, the consideratins that (1) the adjacent landowner is unlikely to be adversely affected by waste infection and (2) the disposal of wastes by injection may be held to be in the public interest could result in decisions to restrict private property rlghts, depending on the region and individual circumstances. The question of the relation of land ownership to the rights to underlying aquifers was recently examined (McMillion), resulting in the conclusions that legal opinions in the eastern half of the United States generally favored control of water rights by the landowner. Th1s view was correlated with the historical existence of a surplus of molsture in this area. On the other hand, legal opinions in the westem half of the United States generally favored the vlew that water is public property, with rights accorded to the first user. This view was correlated with the historical deficiency of molsture in this area.

\section{Liab111ty}

In the event that the operation of a waste-injection well should result in injury to a person or to property, the party carrying out the operation may be judged accountable. The infured party might bring sult on the 
basis of (1) trespass, clalming infingement of property rights or Invasion of property; (2) negligence, claiming conduct dors not meet legal standards, or unreasonable risk of harm, or fallure to take necessary action to protect others; (3) strlct llability, claiming considerable threat to others even when conducted with every possible precaution; and (4) nulsance, claiming unreasonable interference with the use of enjoyment ol land. Although such suits involving waste injection specfflidly are not on recurd at this $t$ ime, claims of the types 1 isted above have been tried in other geologic operat Ions (Cox).

\section{ENVIRONMENTAL IMPACT}

The objective of deep-well injection of LLAW is to dispose of this waste with less environmental impact than would be incurred in the methods it proposes to replace, $i$.e., discharge to the atmosphere or to surface streams. hny method must be examined, however, for Its own possible environmental impacts. Accordingly, some conceptual environmental impacts of deep-well Injection and a brief consideration of the review procedures tn which It may be subjected are presented in this section.

\section{A. Required Envf ronmental Review Procedures}

The National Environmental Policy Act of 1969 requires that "all agencles of the Federal Government shall . . . Include in every recommendacion or report for legisiation and other major Federal actions significantly affecting the quality of the human environment, a detalled statement by the responsible of ficial on--

1. the envitonmental impact of the proposed action.

2. any adverse environmental effects which cannit be avolded sliould the proposal be implemented,

3. alternatives to the proposed action,

4. the relationship between local short-term uses of an's environment and the maintenance and enhancement of long-tere productivity, and

5. any Irreverable and Irretrlevable combitments of resources which would be involved in the proposed action should it be laplesented."

Since passage of NEPA, all Federal agencles have developed guidelines for formulation of environmental impact atatements. Ineofar as is known, perhaps the only detalled atatement yet prepared concerning any injection well is the otatement filed by EPA with the CEQ concerning the injection of treated sewage into the Floridan aquifer (USEPA 1973B, USEPA 1973C). The draft etatement for the Kerr-McGee Corporation's uraniun hexaflunride plant In Sequoyah County. Oklahosa, contalned a brlef discusetion of the well constructed at that plant, which was interded for raffinat. dioposal. The comany 's application for use of the vell was denied, as 10 discuesed elsehwere In th1s report (IX.B), and diecusetion of the well was probably either eliainated froe the final etatement or reduced to only a mention of lte existence. 
B. General Observat Lons on Environmental Impact of Deep-We11 Waste Inject I on

In a studi completed in. June 1973, by Wapora, Inc., Washington, D.C., under U.S. Fit itonment al Protection contract 68-01-0727, with Dr. D. L. Warner as consultant, an inventory of existing infection wells in the United States was undertaken (USEPA 1974). As part of the study, the results of an assessment of the environmental Impact of each of the infection wells that had been constructed and operated at that time was summarlzed (Warner 1972) as follows: tangilile results of wastewater infection thet can be predicted to occur in every case are:

1. Modification of the groundwater system;

2. Introduction into the subsurface of flutds with a chemical composition different from that of the natural fluids.

Tangible impacts that could occur in individual cases are:

1. Degradation of high-quality groundwater:

2. Contamination of other resources, such as petroleum, coal, or chemical brines:

3. St imulation of earthqiakes;

4. Chemical react ion between wastewater and natural water;

5. Chemical react ion between wastewater and rocks in the injection Incerval.

The 1mpact of greacest concern to most regulatory agencles ls contaminat ion of potable groundwater. Thls could occur by:

1. Escape of wastewater through the wellbore Into a fresh-water aquifer because of inadequate casing, corrosiun, or other fallure of the injection-well casing:

2. Vertical escape of injected wastewater, out Bide the well casing. from the injection zone Into a fresh-water aquifer:

3. Vertical escape of Injected wastewater irom the infection zone through confining bede that are Inadequate because of high primary permeabllity, solution channele, Jolnts, faults, or indiced fracturea:

4. Vertical escape of injected wastewater frov the injection zone through other, nearby, deep vells that are laproperly ceaented or plugged, or that have insufficient or corroded casing.

Direct contanination of fresh grounduater could aleo occur by lateral travel of injected wastewater troe a region of saline water to a region of frewh water In the sase aquifer. In mot casen, the distances involved and the low rates of cravel of wastevater ake the probability oi dirait contamInation very anall.

Indirect contenination of fresh groundweter with wilne formation water can also occur a a reeult of the displecenent of formation vater by injected wastcweter. Vertical flow of the eal the vater would occur chrough pathe of natural 
or induced permeability in confining beds or through other Inadequately cased or plugged deep wells. If large volumes of wastewater were injected near a fresh water-saline water interface, such as occurs in many coastal aquifers and also in inland locations, the interface could be displaced, with saline water replacing freshwater in the zone of displacement. During the present survey, it was found that in most presently existing wells, the potential for direct contamination of fresh groundwater 18 small because of the construc$t$ ion used in these wells and because of the large vertical distance between the injection zones and fresh-water aquifers. The belief that the potential for this type of contamination is small 18 supported by the small number of instances of documented direct contamination.

No instances of contamination of other subsurface resources by injected industr1. I wastewater has yet been reported. The fact that little evidence has been found of degradation of potable groundwater and other resources bv this type of injected wastewater should not be cause for relaxing vigilance in regulating and operat ing such wells. On the contrary, as more we $11 \mathrm{~s}$ are constructed, regulation and operation must be increasingly more sophisticated to maintain this record.

Chemical reaction between wastewater and formation water and minerals constitute an alteration of the natural environment (II.E.3.), but does not present much potential for environmental impact that would be of concern to the public.

The exact geologic and hydrologic circumstances in which earthquakes can be stimulated by wastewater infection are not yet known. However, the general requirement is that a fault be present, along which movement can be Induced, in an area containing earth strains that can be relleved by movement along the fault. Ii is helieved that fluid injection can act as a trigger for release of such strain energy, thus causing an earthquake. Of the wells in the present inventory, very few are in such locat lons, and none except the Rocky Mountain Arsenal well near Denver has yet been definitely related to earthquake occurrence. This discussion generally relates to items 1 and 2 and parts of 4 and 5 of the requirements for environmertal impact statements (EIS).

Items 2, 4, and 5 of the EIs requirements are interrelated in the case of wastewater infection, in which subsurface storage space is the resource being comitted and 1 ts commitment leads to the two lmpacts that will occur in every case (listed above) and possibly preempts, for some time, other uses. The amount of space occupled by the wastewater can easily be calculated because each unit voluwe of waste occuples a unit volume of pore space in the subsurface. Before injection, the pore space 18 not vacant, but 18 filled with water, oll, or gas (oll or gas very rarely). Therefore, the waste displaces natural formation water. The ultiate effect of unbalancing the subsurface fluid system is site related and cannot be generallized. However, Infection of small volumes of wastewater under discussion would not be expected to have a $81 \mathrm{gnif}$ icant effect at most 81 tes that would be approved for use. Th1s should not be sesumed however, but should be determined for each Individual case by the methods outlined in Section ill. A eccondary result of displacing natural formation fluids 18 indirect types of groundwater pollution, also discussed above; this possibllity must be evaluated for each alte. The only future uses (other than the use of potable water) that aght be foreclosed or restricted by infection of low-level wastewater are the production of brine for Ita chemical content and the injection of other 
fluids within the area of pressure influence of the low-level waste infection well or wells. There should be no significant effect on mineral resources that might be present.

\section{Possible Environmental Effects of Specific Contaminants}

The Inevitable and possible impacts of injection of LLAW can be anticipated but still cannot be analyzed in detail unt 11 they can be related to a particular site. Because of the generally low levels of other nonradiuactive chemicals, the principal hazard to potable groundwater is nitrate.

As previously discussed (Il.F.1.), nitrate is present in normal low-level wastewater at an estimated concentration of about $620 \mathrm{mg} / 1$ (Table 2 footnotes), which 1814 times the recommended $11 \mathrm{mit}$ of $45 \mathrm{mg} / 1$ in the Public Health Service cirinking water standards. In the process upset waste, nitrate would remain the most objectionable nonradioactjve constituent. It 18 estimated that it would be present at a concentration of $6 \times 10^{4}$ to $12 \times 10^{4} \mathrm{mg} / 1$, or 1400 to 2800 times 1 ts recommended 1 imit in drinking water. It is very unlikely, however, that anyone would drink the process upset wastewater at 1 ts full concentration because 1ts dissolved sollds content would be two to four times that of seawater, making it too saline for consumption.

A severe circumstance would result if injected wastewater directly entered an aquifer used for drinking water supply. In that case, up to 14 volumes of potable water could be contaminated to the Publlc Health Service nitrate limit for each volume of normal wastewater entering the aquifer. Assuming a water usage of 100 gallons per person per day and a $5 \mathrm{mU} / \mathrm{day}$ plant disposing of wastewater at the rate of $50,000 \mathrm{gpd}$, a maximum of 6900 persons could be consuming water contaminated to the specified limit. Consumption of the contaminated water includes washing, bathing, etc.; and about 1 to 211 ter per day would be used for drinking. The calculation 18 somewhat unrealistic, but points toward the limits within which the effects of a pollution event would fall. However, McKee and Wolf (1963, p. 224) cite a reference in which it was reported that drinking one liter of water containing $500 \mathrm{mg} / 1$ of nitrate can cause 1:ritation of the mucous linings of the gastrointestinal tract and bladder, with symptoms of diarthea and diuresis.

Similar calculations can be carried out for radioactive constituents of LLAW that are present in concentrations greater than their respective guideline concentrations. Those radioactive constituents, as shown by Table 14 , are ${ }^{3} \mathrm{H},{ }^{90} \mathrm{Sr},{ }^{129} \mathrm{I}$, and ${ }^{131} \mathrm{~L}$.

An additional assessment of environmental effects can be obtained by estimating the range of tritium doses possible from consumption of LLAW as a result of the leakage of emplaced waste from the receiving aquifer to "public water supply. The concentrations of trit lum available to consumers through ouch a aishap are assumed to be lower than the concentration in LLAW (Table 15) because of dilution either by native fluldg of the aquifer into which the waste was placed, or by frush-water sources of the public water supply. The conditione and results of these calculations are shown in Table 15, which Indicate that in the unlikely event that the LLAW of a 5 MTU/day fuel reprocessing plant is completely consumed, the population dose would be $3 \times 10^{5}$ person-rem/yr. This dose, resulting from the worst case accident, is about 80 times greater than the est imated dose of $3.9 \times 10^{3}$ person-rem/yr for conven- 
Table 14. Estimate of Maximum Number of Persons that could be Exposed to Water Containing the Maximum Permissible Concentration of Contaminant by Hypothetical Leakage of ILAW from Injection Weil for a $5 \mathrm{MTU} /$ day Fuel Reprocessing Plant into Public Water Supply

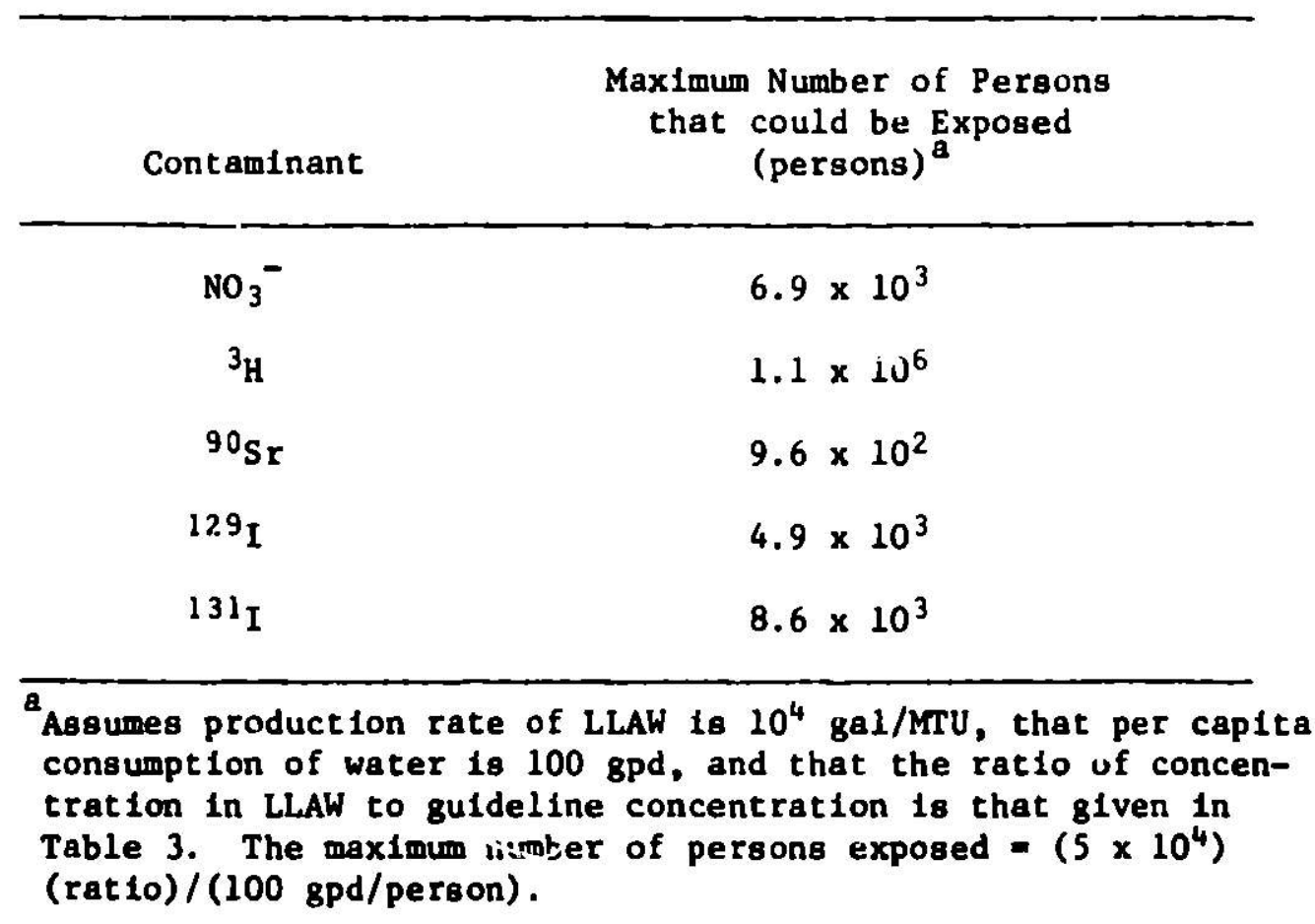


Table 15. Estimated Ef fects from Tritium Incurred through Continuci:s Drinking, of Wat.er Contaminated by Leakage of LLAW from Waste Well of a $5 \mathrm{mu} / \mathrm{day}$ Fue! Reprocessing Plant Into Public Water Supply

\begin{tabular}{|c|c|c|c|c|c|}
\hline Dilution & $\begin{array}{l}\text { Conc. } \\
\text { (uC1 Tritiun/ml) }\end{array}$ & $\begin{array}{l}\text { Vol. of Contaminated } \\
\text { Hater Cunsumed } \\
\text { (gal/day) }\end{array}$ & $\begin{array}{l}\text { Maximum } \\
\text { Persons } \\
\text { Served }^{b}\end{array}$ & $\begin{array}{c}\text { Individual Dose } \\
\text { (whole-body) } \\
\text { (rem/yr) }\end{array}$ & $\begin{array}{l}\text { Population Dose } \\
\text { (whole-body) } \\
\text { (Ferson-rem/yr) }\end{array}$ \\
\hline \multicolumn{6}{|c|}{ Percentage of Injected LLAW Consumed = $100 \mathrm{x}$} \\
\hline $2000: !^{d}$ & $3 \times 10^{-3 e}$ & $1 \times 10^{\theta f}$ & $1 \times 10^{6}$ & 0.3 & $3 \times 10^{5}$ \\
\hline \multicolumn{6}{|c|}{ Percentage of Injected LLAW Consumed $=1.37^{8}$} \\
\hline 2000: 1 & $3 \times 10^{-3 e}$ & $1.3 \times 10^{6 f}, 8$ & $1.3 \times 10^{4}$ & 0.3 & $3.9 \times 10^{38}$ \\
\hline
\end{tabular}

concelving that LLAH leaking from a recelving aquifer into a public water supply may be diluted elther by flalds native to the receiving aquifer or by freshwater sources. Asgunes a per capita consumpicion of $100 \mathrm{gpd}$, of which only a small portion (1-2 11ter per day) 1s used for drinking.

CAssumes that the dose received as a result of continuous drinking of tritlated water is $100(\mathrm{rem} / \mathrm{s}:) /(\mu \mathrm{C} / \mathrm{ml})$ (USEPA 1973A).

dAssures the concentration listed in Table 2.

Chosen to correspond to the radiation concentration guideline for 168-hr/week exposure to tritiated watic (CFR).

fasure that the production rate of Li.AW $1810^{4} \mathrm{gal} / \mathrm{MTU}$.

${ }^{8}$ Chosen to pernit comarison with the estimated value of 3900 person-rem/yt dose for conventional discharge of LLAl into the atmosphere or surface streams. 
tlonal discharge of tritiated waste. Deer-well injection without mishal, however, would avoid all or a large fraction of this conventional dose, on the assumption that all or a large fraction of LWR-produced tritium accumulates in LLAW.

Table 15 also shows that $1.3 \%$ of the LLAW, regardless of dilution, must be consumed to equal the $3.9 \times 10^{3}$ person-rem/yr estimated to result from convent lonal discharge of LLAW.

VII. WELL DECOMISSIONING

Varlablios determining the operating lifetime for an indiviuual well include:

1. The rate of pressure buildup in the injection hortzon,

2. The distance of waste travel,

3. Fallure of Irreplaceable components in the system, such as the wellbore itself or the infection casing;

4. Changes in waste treatment technology, regulatory controls, or plant operations,

5. Decommissioning of the waste-producing operations, e.g., In the present case, the decummissioning of the fuel-reprocessing plant.

Well abandonment, for whatever reasons, will require procedures aimed at minfmizing the probability of future environmental damage. At least two actions are required in the interest of this objective--plugging of the well to prevent the escape of injected wastes, and filing a record of the history of the well with the appropriate state and federal agencies to minimize the possibility of anyone inadvertently drilling into the disposal zone and allowing the injected waste to escape.

Many states, particularly those involved in petroleum production, have an dgency charged with supervising the abandonment of deep wells. Hater well abandonment 18 also somet imes regulated. Typlcally, regulatione require submission of a plan for plugging of a deep well and require that an Inopector be present when plugging occurs. Specific requirements of present-day regulations of ten Include segregation of water-bearing intervals with cenent and the plugging of other intervals with "mud or other equally nonporous aterials." It is recomended that waste injection wells be plugged from the botton to the ourface with cement to provide the greatest possible segregation of aquifers. Deep monitoring wells should be plugged elmilarly. In com disposel well -ituations, however, monitoring of the infection zone for som time after infection ceases an be desirable or required by local regulatione. In euch cases, the infection will would be left unplugged for a parlod of cira to allow recording of pressure fall-off. Monitoring welle alght also be left unplugged to porntt continuing measurenent of aquifer fluld pressure and for earpling of aquifer vater.

\footnotetext{
"Plugging 10 eseuned to be permanent.
} 
The pulling of casing (which is sometimes allowed during the abandonment of oll and gas wells) should be entirely forbidden in the case of wasteinfection wells. In addition, ofl and gas well abandonment regulations sometimes require cutting of the surface casing below the ground, the intent being to prevent interference with farming or other uses of the land. In contrast to this practice, it is suggested that a permanent surface monument be established at the location of waste-inject ion wells at the time they are abandoned, so that there will be no future doubt concerning the vell location.

\section{COSTS}

\section{A. Review of Other Cost Studies and Selection of Cost Methods to be Used in This Work}

Several previous studies have dealt entirely or partly with the costs of wastewater infection. A number have been concerned only with disposal of desal ination plant brines (Koen18 1958; Holloway; LeGros 1969, 1970; IWS). Koenig (1964) discussed the costs of deep-well infection and other advanced waste treatments. Other studies (Moseley, Haynes) were concerned with industrtal wastes In general and included the development of computer programs for des!gn and cost estimation.

Since none of the estimating methods of the studles listed above perfectly match the needs of the present work, the following rationale was adopted for estimating the costs of disposal of LLAW by deep-well in ection: An annual expense was estimated, based on fixed capltal costs and operating costs associated with process ing a given volume of LLAU from a model fuel reprocessing plant. Frow this unit expense and the assumed volume of LLAW per unit of nuclear energy produced, a cost of deep-well injection of LLAW in mills/kth vas derived. The capital costs considered included those for well construction, punping cyulpment, and facilities for preinjection treatment of LLAW. The operating expense, considered included power costs, chemicals, pumping operations, preinjection treatment operat lons, and well inspection and waintenance operat lons. Many of these capital and operat ing cost categories are further itemized below. The resulting cost est Imates mut be considered to be of limited accuracy because of changes in the value of the dollar and the cost of goods and services, and also because of the garlation of costs with depth and geologic characteristics. A number of other costs have been foreseen that are considered to be outalde the redis of accurate estimation at this time because of insufficlent Informet ion directly related to the disposal of LLAW. Theec costs Include assessents for decoesisetoning; cost of exploration and test drillingi cost of construction of monitor vells; cost of monitoring activities; IIcense fees, surety bonde, and other legal fees; and cost of speclal training for operators.

\section{B. Capltal Coete}

\section{Expected Proportion of Capltal Cost to Total Cost}

In his 1964 etudy, Koents surariged avallable Inforeation on the estinated cout of injection weli conatruction and iparacion in the petroleum Industry. He considared vell construction costs, Ine iuding drilling, teeting, and complet ing; puping oquipment coste: and water-conditioning-facility costa. These coste vere computed for the 81 poselble combinations that can arise from 
three cases for each of four varlable parameters chosen for study. The varlable parameters and the cases examined were well depth $(3000,7000$, and $12,000 \mathrm{ft})$, dally volume $(1000,100,000$, and 2 million $\mathrm{gpd})$, spectflc gravity of waste $(1.00,1.005$, and 1.187$)$, and injection pressure $(0,260$, and $900 \mathrm{ps} 1)$. The range of cases selected by Koenig appear to be realistic when compared with existing deep-well injertion facilities.

According to Koenig's analysis, the proportion of total costs that constitutes fixed cost increases as the injection rate decreases. Fixed costs would bc expected to account for nearly the total cost per volume of injected waste in systems that infect only small umounts of waste. Low-level radioactive waste volumes ( 250,000 gpd for a plant processing up to $5 \mathrm{MTU} /$ day) are sufficiently small, compared with volumes injected by other industries that, according to Koenig's analysis, flxed costs are expected to comprise more than half of the total cost of disposal and could comprise nearly the entire cost in cases where well-head injection pressures are very low.

\section{Wel1 Construction Costs}

Possible approaches to estimating construction costs for a well to dispose of LLAW Include:

1. Obtaining costs for wells disposing of other types of waste and developing curves representing experienced $\cos t s$, from which predictions could be made.

2. Synthesizing costs for selected examples.

3. Using recent average 011 and gas well costs as a basis for predicting probable disposal-well costs.

The first approach 18 refected here because insufficient data are avallable to allow 1 ts use. The second approach would be satisfactory for a few examples, but it is time-consuming and would not provide means of easily obtaining a cost for a case other than the one presented. The third approach was selected because it provided the greatest amount of information for the least amount of efíort. Also, Koen1g (as described above) synthesized a large number of examples and found that his eynthesized well construction costs compared closely with the average costs of wells, determined by annual ourveys conducted by the petroleum Industry.

In accordance with the third approach to cost estimation, the most recent average well construction costs avallable are shown in Fig. 30 . This Figure was prepared using data from the 1973 "Joint Association Survey of Industry Drilling Costs," which is conducted by the American Petroleum Institute, the Independent Petroleum Association of America, and the MId-Continent 011 and Gas Association. The cost figures given include both intanglble costs and tangible costs. Intangible drilling costs Includes all amounts piald to contractors and all expenditures for labor, drilling mud, supplies, water, fuel and power, transportation, etc. that are used in locacion, drill site pleparation, erecting, and dismantling $r_{8}$ and derrick; driling the hole; running casing; cementing; cording; and format lon testing. Tangible costs Include the costs of casing, tubing, and well-head flttinge. The cost of puspling or other artifical lift equipment, even though such equipment is inetalled during the Initial completion of the well, is excluded. Also, the cost of flow lines, 


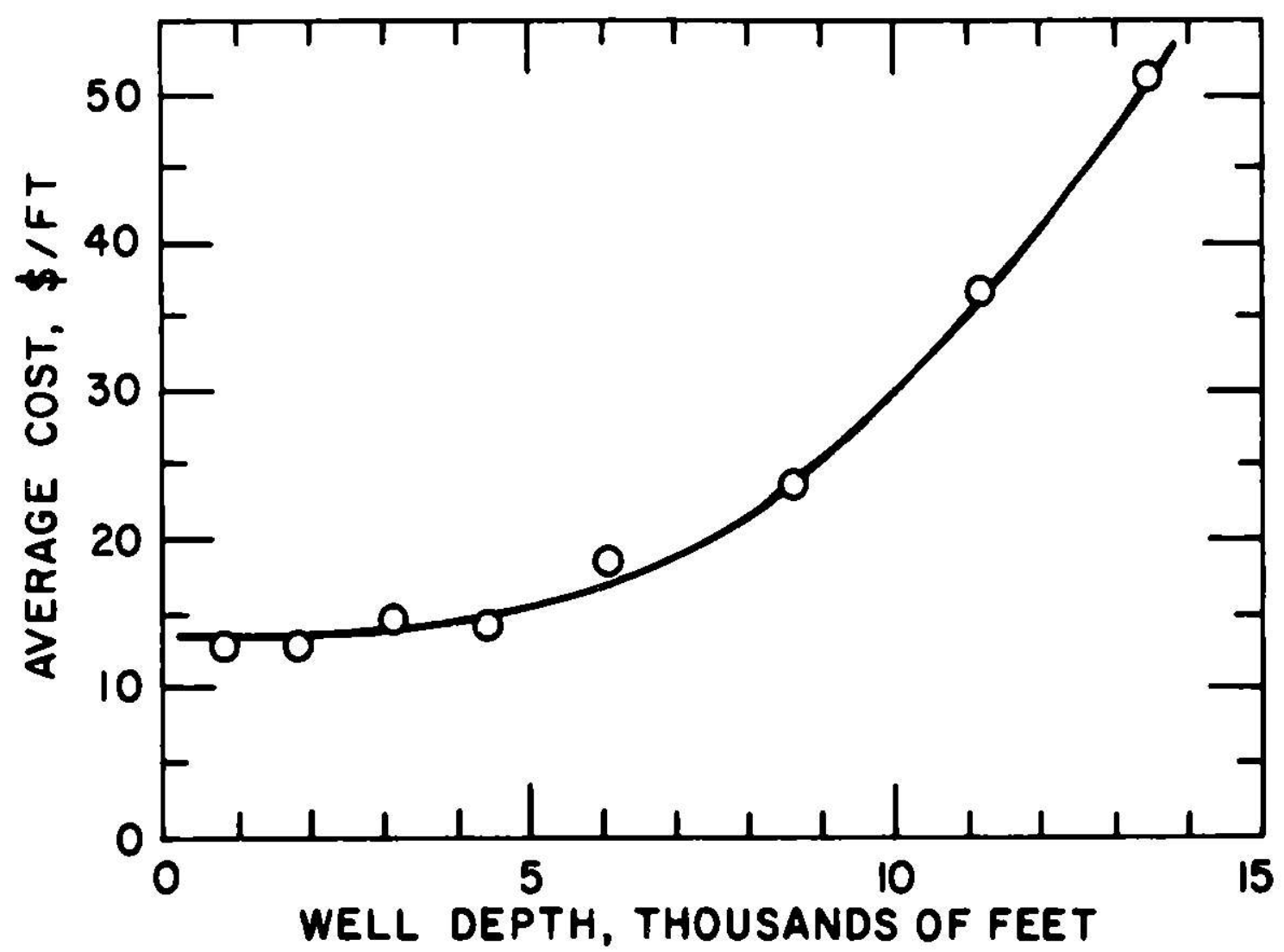

F1g. 30, Average Construction Cost of 011 and Gas Wells in the United States in 1973. Prepured from Data in the Joint Association Survey of Drilling Costs (API 1975).

separators, lease tanks, and simllar well completion and lease facillties are excluded because the costs are for wells, not surface facilities.

From Fig. 30 It can be seen that the average cost per foot of o1l and $8 a 8$ wells constructed in 1973 increased only about $\$ 2.00$ per foot between 1000 and $5000 \mathrm{ft}$. However, at depths greater than $5000 \mathrm{ft}$, the cost per foot Increased much more rapidly, doubling between 5000 and $10,000 \mathrm{ft}$.

Because the data in F1g. 30 are from 1973, they must be adjusted for inflation. This can be done with the widely used Bigineering News Record Bullding Cost Index (ENR), whlch ts given in Table 16. A current cost 18 derived by multiplying by the ratio of the current index to the 1973 index. Th1s table can be used for other item also. The Index 18 a welghted one that 
Table 16. Engineering News Record Bullding Cost Index (ENR).

\begin{tabular}{lccc}
\hline Year & $\begin{array}{c}\text { Annual } \\
\text { Average } \\
\text { Index }\end{array}$ & Year & $\begin{array}{c}\text { Annual } \\
\text { Average } \\
\text { Index }\end{array}$ \\
\hline 1960 & 559 & 1968 & 721 \\
1961 & 568 & 1969 & 790 \\
1962 & 580 & 1970 & 836 \\
1963 & 594 & 1971 & 948 \\
1964 & 612 & 1972 & 1048 \\
1965 & 627 & 1973 & 1138 \\
1966 & 650 & 1974 & 1204 \\
1967 & 672 & 1975 (March) & 1265 \\
\hline
\end{tabular}


considers the cost of structural steel, portland cement, lumber, and skilled labor.

Although the Joint Association Survey data in Fig. 30 give a rapid means of obtaining a cost estimate, which is otherwise very time consuming to obtain, experlence has shown that the cost of a typical oil and gas well will in most cases be less than the cost of an industrial wastewater injection well of the same depth. No statistics have been prepared to show the magnitude of difference, but it exists for the following reasons:

1. The well costs in Fig. 30 frequently do not include injection tubing or tubing packers and the casing of oil and gas wells is ordinarily carbon steel where the casing may be partly or wholly fabricated of an expensive alloy in an injection well.

2. Well diameters are not specifled in the Joint Association Survey, which takes into account only well depth. A typical waste injection well probably has a larger diameter than a typical average oil and gas well has because the volumes of fluid it handles are larger and because well design is generally on the conservative side.

3. Only par: of the casing in o1l and gas wells is cemented, whereas in most injection wells the casing is cemented to the surface.

4. A typical ofl or gas well receives only a minimum logging, coring, and testing program in comparison with a wastewater infection well.

5. Most ofl and gas wells are drilled in an area where drilling conditions are well known and the targets are famlliar ones; injection wells are frequently drilled in less well known areas and for uncommon targets. This causes drilling costs to be greater for Injection wells.

6. Engineering costs are not included in the cost for a typical oil and gas well because these services are provided by company personnel.

In spite of these deficlencies, average ofl and gas well costs do provide a reasonable basis for a minimum cost estimate and can be adjusted by an arbitrary factor of 25, 50, or even 100 percent to test the effect on the cost per unit volume of waste disposed. Although the cost of an injection well 18 expected to be more than that of a gas or ofl well of the same depth, the cost of a monitoring well (1f retalned strictly for monitoring and not intended for later conversion to infection) might be less than the cost of an oll or gas well of the same depth.

\section{Injection Pumping Equipment}

The cost of pumping equipment is directly related to the pumping power required. The necessary pump horespower 18 calculated by summing the various pressuren to determine what the punp pressure will be. The presaure balance equation 18:

$$
P_{B}=P_{b h}+P_{f}-P_{h}
$$


where $P_{S}=$ surface injection pressure

$\mathrm{P}_{\mathrm{bh}}=$ bottom-hole injection pressure

$\mathrm{P}_{\mathrm{f}}=$ pressure lost by friction in the injection tubing

$P_{h}=$ hydrostatic pressure contributed by the column of wastewater in the hole.

The hydraulic horsepower needed ts then:

$$
\mathrm{HHP}=\frac{\mathrm{P}_{\mathrm{S}} \mathrm{Q}}{1714}
$$

where HHP = hydraulic horsepower needed for injection

$P_{\mathrm{s}}=$ surface injection pressure (psi)

$Q=$ injection rate (gpm)

Pump horsepower must be greater than the hydraulic horsepower, because of pump friction losses. A value of 0.85 is commonly used for pump efficiency (Holloway).

A flow volume of $35 \mathrm{gpm}$ is assumed, based on $10^{4} \mathrm{gal} / \mathrm{MTU}$ at a plant processing $5 \mathrm{MrU} / \mathrm{day}$. A reasonably high value for wellhead injection pressure is $3000 \mathrm{ps}$. This would be the approximate maximum allowable in many states in a 10,000-ft well, as computed from Equation 1, where $P_{\text {bh }}$ is restricted to $7500 \mathrm{ps} 1$. In this case, for $Q=35 \mathrm{gpm}$, HHP $\cong 61$, and the pump would have to be rated at a miniuum of 72 horsepower (assuming an efficiency of 0.85 , as above).

Pumping equipment costs include costs for the pump, motor, controls and wiring, foundation and housing, and labor for installation. A review of 1975 prices of such pumping units indicated that its installed price should not exceed $\$ 20,000$, a figure that can be used as an approximate maximum cost for pumping equipment at this time. One other example was checked in which a flow rate of $35 \mathrm{gpm}$ and a wellhead infection pressure of 500 psi were assumed. In that case, a 12-horsepower pump and motor would be required at a total cost of about $\$ 5,000$.

\section{Waste Pretreatment Factlities}

The pretreatment of LLAW is assumed to consist only of neutralization and filtration. The capital cost of the equipment involved was estimated to be $\$ 76,000$ by interpolation of the data of Koenig (1964) and adjustment by the ENR index, for a 50,000 gpd capacity. This value is in good agreement with an estimate by a water conditioning company of $\$ 77,500$ (Infilco).

\section{Operating Costs}

\section{Power Costs}

The procedure for obtaining infection pump horgepower requirements 1s described above. Power requirements are calculated by converting from horsepower-liours to kilowatt-hours and by assuming a motor efficlency of 93 percent (Holloway). The power requirement per hour of operation is then: 


$$
\begin{gathered}
\mathrm{KWH}=\frac{\mathrm{PHP}}{0.93} \times \frac{0.7457 \mathrm{KWH}}{\mathrm{HPH}} \\
\mathrm{KWH}=0.80 ? \mathrm{PHP}
\end{gathered}
$$

where $\mathrm{KWH}=$ k1lowat hours

PHP = pump horsepower

$\mathrm{HPH}=$ horsepower hours

If a power cost of one cent per kflowat hour is assumed, the energy cost per horsepower-hour for injection pump operation is $\$ 0.008$. oThis same figure can be applied to the transfer pumps in the pretreatmen: plant.

\section{Chemicals for Wastewater Treatment}

It has been suggested that the LLAW be neutralized to reduce the cost of corrosion and to avold the operating problems that frequently occur when infecting corrosive wastes. It will be assumed that the neutralizing agent will be industrial grade sodiun hydroxide, which in bulk quantities is sold dry or in concentrations of 50 to 30 percent in aqueous solution.

Sodium hydroxide, at a concentration of 50 percent by welght, is 19 molar, Therefore, a volumetric ratio of $1: 1900$ for sodium hydroxide to normal wastewater $\left(0.01\right.$ molar $\left.\mathrm{HNO}_{3}\right)$ is required to achleve neutrallty. During a process upset, the ratio would range from $1: 19$ to $1: 9.5$. Since commercial grade sodium hydroxide (caustic soda) presently costs about $\$ 0.50$ per gallon at this concentration, the cost of this chemical, for a $5 \mathrm{MTU} /$ day plant, would be about $\$ 13$ per day for normal wastewater and $\$ 130$ to $\$ 260$ per day for inf requent treatment of process upset wastewater.

\section{Other Operating Costs}

The following operational costs related to pumping operations were obtained from data of Koenig (1964) and adjusted to 1975 by the ENR index:

1. Operation labor and ma1ntenance: $\$ 0.0360 /$ HHP day,

2. Repairs to pumps and motors: \$0.1340/HHP day,

3. General and administrative: $\$ 0.0252 / \mathrm{HHP}$ day.

Operating costs associated with the pretreatment plant were obtained by interpolation of the data of Koenig (1964) and adjusted to 1975 by the ENR Index:

1. Dally cost of repair, equipment and facilities: $\$ 0.103 / 1000 \mathrm{gal}$,

2. Dally cost of labor: $\$ 0.153 / 1000 \mathrm{gal}$,

3. General and administrative: 50 percent of labor cost.

A further significant cost may be that for perlodic inspection of injection tubing casing and perlodic well testing and workover. Th1s is a generally desirable practice, as discussed in Chapter IV, and may be a regulatory requirement in the future. Its cost 18 not easily estimated, but an arbitrary figure of 10 percent of the fixed well cost per year is suggested as 
reasonable. Alternatively, the procedure of allocating a fixed cost per foot per year to well workovers could be used (Holloway'. Iu 1975 dollars, their suggested figure would be about $\$ 2.00$ per foot. The two methods may be compared for a 6000-ft-deep well-- the cust suggested would be $\$ 12,000$ per year and 10 percent of the total cost if $\$ 113,200$ (frum Fig. 30) would be $\$ 11,320$ per year.

The capital and operating costs for two examples, assembled from the foregoing bases for cost estimation, are listed in Table 17. These examples were chosen to represent a combination of higher pressure and greater depth and a combluation of lower pressure and lesser depth.

Lifetime costs were also estimated, from a sum of capital and operating costs, with the assuraptions that the capital cost wou'd re retired over a 10yr period at an interest rate of 10 percent, that the plant 11 fetime would be 40 years, and that the annual inflation rate for operating cost would be 5 percent. Therefore, the total cost 1s:

$$
T C=(I)\left(C R F_{10}^{10}\right) \times 10+\sum_{1}^{40}\left(O C_{1}\right)(1.05)^{n-1}
$$

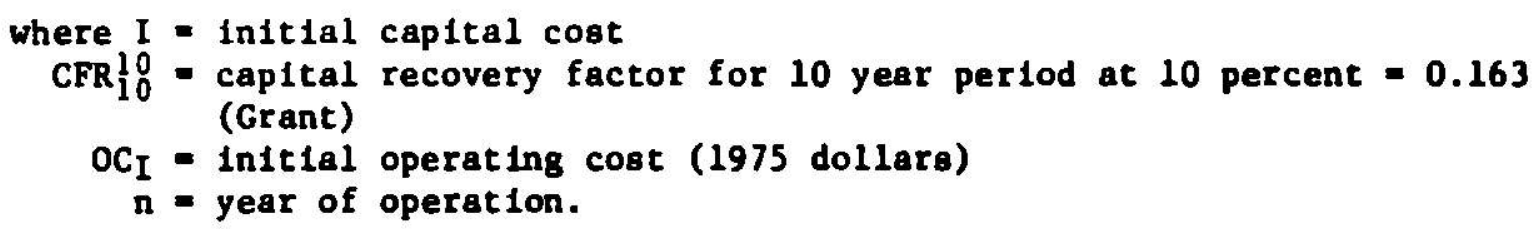

The IIfetime costs for the examples deacribed in Table 17 are 11sted in Table 18.

Other detailed cost estimates of deep well injection of LLAW that could be compared with costs listed in Tables 17 and 18 are not readily avallable. A cost estimate of conceptual application of deep-well injection of LLAW at the Midwest Fi:el Reprocessing plant was cited (NEDO-14504-2) as 0.4 to 0.5 million dollars. No explanation was given to indicate what type of costs were assumed, whether capital, operating, or total. The Aquafluor flow shaet of the original MFRP concept was atypical in that it discharged only about 400 gal/MTU of LLAW because of a lower flowage of water per MTU processed, and also recycle of about $280 \mathrm{gal} / \mathrm{Mr}$ back to the leacher (Rhinehasmar). Thus, estimates of ccote of deep-well injection based on volume vould be relatively low.

The cos: 3 of deep well infection per unlt of electric energy generated, estimated from the totals in Table 18, ascuming a $5 \mathrm{~m}$, day reprocessing plant that services fifty 1000-ine reactore per year and aseuning that each reactor produced $7 \times 10^{9} \mathrm{kWh}$ of energy per year, are $1.4 \times 10^{-4} \mathrm{nill} / \mathrm{kth}$ and $2.7 \times 10^{-4}$ mill/kwh for the two examples. These unit coste are low in comparison with a recent eetiate of $0.05 \mathrm{alll} / \mathrm{klh}$ euggested for allocation to the total wate managenent operations in the LWR fuel cycle (WASH-1174-74).

\footnotetext{
The totale of Table 18 neglect soas coste thet cannot be eccurately eatinated at this tim (VIII.A.).
} 
Table 17. Estimated Costs for Two Examples of Deep-Well Injection of LLAW

Capical Costo (1975)

\begin{tabular}{|c|c|c|}
\hline & $\begin{array}{l}6,000 \mathrm{ft}, \\
3,000 \mathrm{psi}\end{array}$ & $\begin{array}{r}1,000 \mathrm{ft} \\
500 \mathrm{psi}\end{array}$ \\
\hline Well Construction & $\$ 113,200$ & $\$ 15,000$ \\
\hline Pumping Equipaent & 20,600 & 5,000 \\
\hline Pritreatment Fuc1litles & 76,000 & 76,000 \\
\hline Total Cap1tal Cost (1975) & $\$ 209,200$ & $\$ 96,000$ \\
\hline \multicolumn{3}{|c|}{ Annual Operating Coste (1975) } \\
\hline \multicolumn{2}{|l|}{ Punp1ng } & 700 \\
\hline Labor \& Maint. & 660 & 660 \\
\hline Repairs & 2,460 & 2,460 \\
\hline General \& Adminietrative & 460 & 460 \\
\hline $\begin{array}{l}\text { Pretreatment } \\
\text { Labor }\end{array}$ & $\$ 2,300$ & $\$ 2,300$ \\
\hline Repairs & 1,500 & 1,500 \\
\hline General Adminiotrative & 1,150 & 1,150 \\
\hline Chentcals & 3,900 & 3,900 \\
\hline Perlodic Well Testing Workover & 12,000 & 2,000 \\
\hline Total Annual Operatıng Cost (1975) & $\$ 28,430$ & $\$ 15,130$ \\
\hline
\end{tabular}


Table 18. Plant Lifetime Costs of Deep Well Injection of LLAW for Two Examples ${ }^{a}$

$\begin{array}{rr}6,000 \mathrm{ft}, & 1,000 \mathrm{ft}, \\ 3,000 \mathrm{pgi} & 500 \mathrm{psi}\end{array}$

Total Capital

Debt Serviceb

$\$ 341,000 \quad \$ 156,500$

Sum of Operating

Costs ${ }^{c}$

$\$ 3,434,300$

$\$ 1,827,700$

Total

$\$ 3,775,300$

$\$ 1,984,200$

a For $5 \mathrm{MTU} /$ day reprocessing plant.

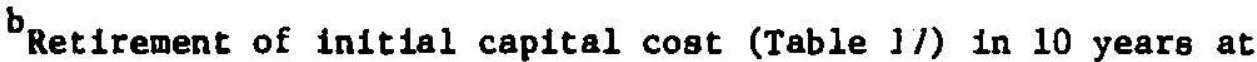
$10 \%$ interest.

Based on 40 years operation with $5 \%$ annual inflation rate. Operating costs for first year listed in Table 17. 
The plant lifetime costs 11 sted in Table 18 also are small compared with an estimated cost that can be assigned to radiation exposure in conventlonal discharges of a $5 \mathrm{MTU} /$ day fuel reprocessing plant: The estimated wholebody exposure to U.S. population from tritium in conventional environmental discharges from a $5 \mathrm{mTU} /$ day plant has been estimated at $3900 \mathrm{man}-\mathrm{rem} / \mathrm{yr}$ (USEPA 1973A). Also, a value of $\$ 1000$ has ween tentatively assigned to an exposure of 1 inan-rem by the Nuclear Regulatory Commission (DOCKET RM-50-2). Therefore, for a plant lifetime of 40 years, the total cost of exposure to U.S. population would be:

$$
40 \text { yr } \times \frac{3900 \text { man-rem }}{y r} \times \frac{\$ 1000}{\text { uan-rem }}=\$ 156 \times 10^{6},
$$

a cost that is much higher than the values of $\$ 2.0 \times 10^{6}$ to $\$ 3.8 \times 10^{6}$ listed for plant-lifetime critium control by deep-well injection in the examples of Table 18.

The est1mated cost of deep wel.' injection can be evaluated in another way, $i . e$. , the amount of money required to prevent a man-rem of radiation exposure. Thus, based on the 40-yr plant lifetime costs of Table 18 and the assumption of 3900 man-rem averted per year for successful deep well disposal, the costs for the two exanples of Table 18 are:

$$
\frac{\$ 3,775,300}{3900 \times 40}=\$ 25 / \text { man-rem tritium exposure prevented, }
$$

and

$$
\frac{\$ 1,984,200}{3960 \times 40}=\$ 12 / \text { man-rem tritium exposure prevented. }
$$

A summary of these cost data ls shown in Table 19.

\section{EXAMPLES}

To provide examples that integrate concepts from the preceding chapters, infection wells at the Anaconda Company uranium m111, Grants, New Mexico, and the Kerr-McGee Corporation uranlum hexafluoride production plant, Sequoyah County, Oklainita, are revlewed here. Also, geologic conditions, and thus the potential for deep-well infection at the Nuclear Fuel Services plant, West Valley, New York; the Allied-Gulf Nuclear Services plant, Barnwell County, South Carolina; and the General Electric Company's Midwest Fuel Reprocessing plant, Morr18, Illino1s, are analyzed. Finally, the use of deep-well infection at the Idaho Chemical Processing plant 1s reviewed.

\section{A. Anaconda Company Injection We11}

\section{General Diacussion}

Only one other wastewater injection well in addition to that at the Idaho Chemical Processing plant 18 known to have been operated in the United States for disposel of radioactive waste. It is located at the Anaconda 


\section{6}

Table 19. Summary of Unit Costs ${ }^{a}$ for Deep-Well Injection of LLAW

\begin{tabular}{|c|c|c|}
\hline Well Conditions & $6,000 \mathrm{ft}, 3,000 \mathrm{psi}$ & $1,000 \mathrm{ft}, 500 \mathrm{pg}$ \\
\hline $\mathrm{mill} / \mathrm{kWh}$ & $2.7 \times 10^{-4 b}$ & $1.5 \times 10^{-4 b}$ \\
\hline$\$ /$ man-rem ${ }^{c}$ prevented & $26^{d}$ & $14^{d}$ \\
\hline
\end{tabular}

Based on the total costs of Table 18.

${ }^{b}$ Compare with an estimate of $0.05 \mathrm{mills} / \mathrm{kWh}$ suggested for total waste management operations connected with the LWR fuel cycle (WASH-1174-74).

Whole body exposure from tritium in LLAW. Assumes that exposure of 3900 manrem per year is prevented at a $5 \mathrm{MTU} /$ day plant.

d Compare to the cost of $\$ 1,000$ tentatively assigned by NRC to exposure to a man-rem of radiation (DOCKET-RY-50-2). 
Company uranlum mill near Grants, New Mexico. Injection was initiated in December 1960, and the well was st111 in operation In January 1973. At that time, a total of about 625 million gajlons of wastewater had been injected with only minor operational problems. Considerable detall 18 presented on this example, because a good deal of information (Arlin; Lynn 1962, 1962A; West; Warner 1967; USEPA 1972; Warner 1972) 1s avallable concerning 1ts construction and operation.

\section{Site Geology}

The disposal well is located in the southern San Juan basin of Colorado and New Mexico (F1g. 23 and 31). The surface rocks consist of shales and siltstones of the Chinle formation (of Trlassic age) which extends to a depth of about $350 \mathrm{ft}$. Beneath the Chinle lie, in descending order, the San Andres, Glorieta, Yeso, and Abo formations of Permian age and the Madera formation of Pennsylvanian age. The total thickness of these sedimentary beds 18 about $2440 \mathrm{ft}$, and they rest on Precambrian age granite gne1ss. All of the sedimentary rock formations crop out in the Zuni Mountains, southwest of the well, and dip about three degrees northeast toward the Sun Juan basin.

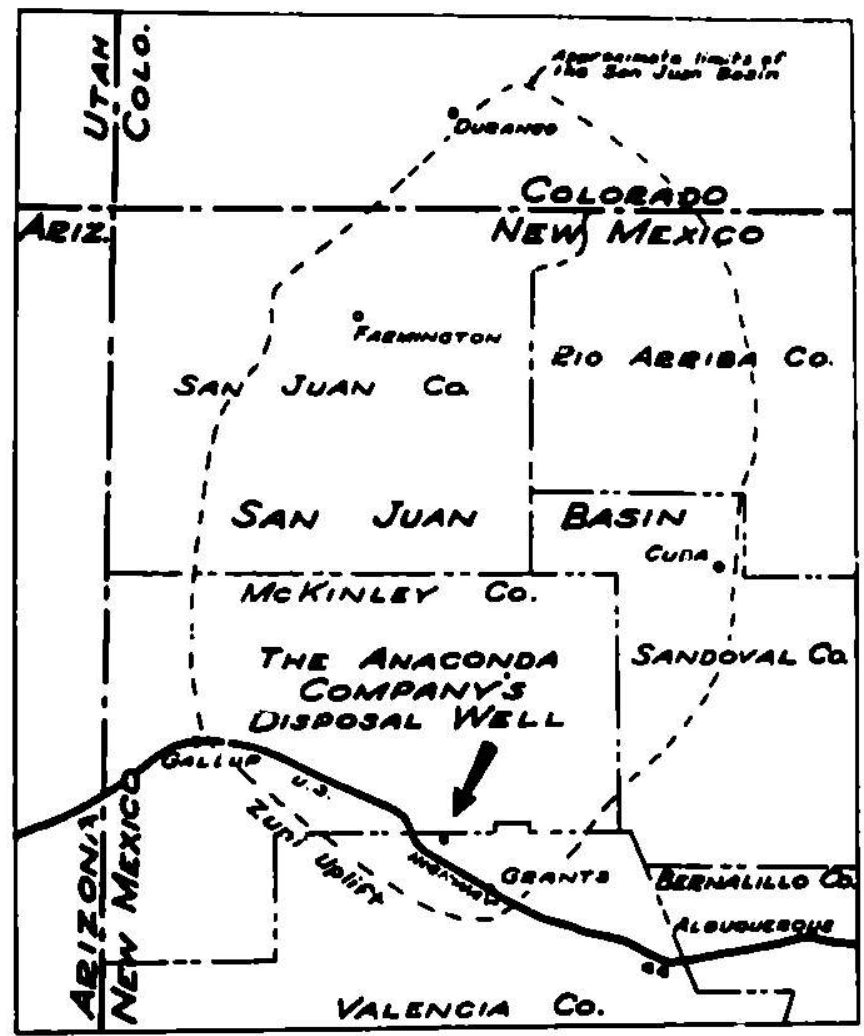

F1g. 31. Map Show ag the Location of the Anaconda Company's Disposal Well (Lynn 1962).

A geohydrologic map of the Grint8, New Mexico, area (Weat) showe considerable faulting, with one fault profected as passing very near the infection well. The significant of thls geologic structure is not evaluated In any avallable publications on the well.

The San Andres formation is a limestone and the Glorieta formation to a sandstone. Together, these two formations comprise an Important ground- 
water aquifer which is the major source of fresh water for agriculture, municipalitles, and Industries in the area. Lesser amounts of fresh water are obtained from the chinle formation and from the alluvium. Water in formations below the Glorieta is saline.

The Yeso formation Is divided Into the San Ysidro and Meseta Blanca Members. The San Ysidro member contains shale, siltstune, limestone, anhydrite, and sandstone bede; the Meseta Blanca Member is principally fine-grained quartz sandstone. The Abo formation is principally siltstone and mudstone. is sample of water taken at a depth of $1305-1450 \mathrm{ft}$ from the Meseta Blanca member showed a total dissolved solids concentration of about $4000 \mathrm{ppm}$. Other chemical characteristics of this formation water are shown in Table 20 . The injection is directed into sandstones in a 563-ft interval in the lower San Yeidro member and Meseta Blanca members. Confinement 18 provided by $300 \mathrm{ft}$ of shale, siltstone, limestone, and anhydrite in the upper San Ysidro Member. The average porosity of sandstones in the injection interval is 16.5 percent, and the average permeability is 105 millidarcies.

\section{Wastewater Character}

The chemical composition of the water injected through the disposal well is the result of adding chemicals in processing the uranium ore, leaching of lons from the ore, and removal of lons from the water either pirposely or by precipitation reactions in the tallings pond. During the firs: few years of mill operation, both limestone and aandstone ores were processid; only sandstone ore has been processed since mid-1959.

In sandstone processing, ore is crushed and then leachisd with sulfuric acid to extract the uranium. Uranium 18 removed from the resultant solution by lon-exchange resins. The acid and the leached sand ore are drained from the lon-exchange vats and flushed to the tailings pond. The uranium 18 removed from the resins with sodium chloride in an acld solution. Lime is added to this solution to increase the $\mathrm{pH}$ sufficiently to precipitate some of the iron, manganese, and aluminum tmpurities leaving the uranium in solution. These impurities are filtered out and are discharged to the tallings pond. Then the uranium 18 precipitated from solution by further increase of the pH. After the uranium precipltate has been removed from the solution by filtration, the spent liquid is released to the tallings pond.

In limestone processing, the uranium had been removed from the ore by water in a "pressure cooker." From that point on, the extraction process was the same as that for the sandstone ore. The leached I1mestone was flushed into the tallings pond. The chemical composition of water in the tallings pond was influenced significantly by the quantities of each type of ore processed and the reactions between the limestone tallings and the strong acid solut Ions.

An average analysis of the wastewater (injection water) composition 18 given In Table 20. A series of chemical analyses run from January 1960 to necember 1965, show some variation (West 1972), as would be expected. The ste lo acid, having a pH range of 2.3 to 2.8 . It 18 enriched in 1 ron, manganese, calcium, magnesium, sodium, sulfate, and chloride during the process of extracting uranium from the sandstone ore. In the early operation of the mill, ammonium nitrate was used inatead of the sodium chloride now used 
Table 20. Chemical Analysis of Formation water, Infection Water, and Returned Infection Water frov the Anaconda Company Well, Grants, New Mexico (Arlin)

\begin{tabular}{|c|c|c|c|c|}
\hline $\begin{array}{l}\text { Chemical } \\
\text { Analyois }\end{array}$ & $\begin{array}{l}\text { Formation } \\
\text { Water } \\
\text { (ppm) }\end{array}$ & $\begin{array}{l}\text { Injection } \\
\text { Water }^{b} \\
\text { (ppm) }\end{array}$ & $\begin{array}{l}\text { Returned } \\
\text { Injection } \\
\text { Waterc } \\
\text { (ppm) }\end{array}$ & $\begin{array}{l}\text { Original } \\
\text { Constituents } \\
\text { Remaining in } \\
\text { Returned } \\
\text { Injection } \\
\text { Water } \\
\quad(x)\end{array}$ \\
\hline $\begin{array}{l}\mathrm{Na} \\
\mathrm{Mg} \\
\mathrm{Ca} \\
\mathrm{Mn} \\
\mathrm{Fe}\end{array}$ & $\begin{array}{l}414 \\
157 \\
592 \\
-2- \\
17.5\end{array}$ & $\begin{array}{r}1,206 \\
411 \\
677 \\
378 \\
439\end{array}$ & $\begin{array}{r}863 \\
646 \\
523 \\
165 \\
56\end{array}$ & $\begin{array}{r}72 \\
157 \\
77 \\
44 \\
13\end{array}$ \\
\hline $\begin{array}{l}\mathrm{Cl} \\
\mathrm{SO}_{4} \\
\mathrm{NO}_{3}\end{array}$ & $\begin{array}{r}304 \\
2,270 \\
\text { Trace }\end{array}$ & $\begin{array}{r}1,725 \\
8,332 \\
130\end{array}$ & $\begin{array}{r}1,298 \\
4,414 \\
35\end{array}$ & $\begin{array}{l}75 \\
53 \\
26\end{array}$ \\
\hline $\begin{array}{l}\text { Total Dissolved } \\
\text { Sollds }\end{array}$ & 4,060 & 16,243 & 9,290 & 57 \\
\hline pH & 7.3 & 2.8 & 5.5 & \\
\hline $\begin{array}{l}\text { Conductance, } \\
\text { MIcromhos }\end{array}$ & 5,400 & 19,000 & 11,800 & 62 \\
\hline $\begin{array}{l}\text { Radioactive } \\
\text { Aralysis }\end{array}$ & $\mu \mathrm{Cl} / \mathrm{mL}$ & $\mu \mathrm{C} 1 / \mathrm{m} 1$ & $\mu \mathrm{Cl} / \mathrm{ml}$ & \\
\hline $\begin{array}{l}\text { Grose Alpha } \\
\text { Uranfum natural } \\
\text { Thorfum-230 } \\
\text { Radium-226 }\end{array}$ & $\begin{array}{c}86 \times 10^{-9} \\
0.22 \times 10^{-9} \\
0.64 \times 10^{-9}\end{array}$ & $\begin{array}{l}3.42 \times 10^{-4} \\
1.73 \times 10^{-5} \\
2.57 \times 10^{-4} \\
5.63 \times 10^{-7}\end{array}$ & $\begin{array}{l}4.64 \times 10^{-7} \\
\therefore .73 \times 10^{-8} \\
8.74 \times 10^{-8} \\
7.48 \times 10^{-8}\end{array}$ & $\begin{array}{l}0.14 \\
0.10 \\
0.03 \\
13.3\end{array}$ \\
\hline \multicolumn{5}{|c|}{$\begin{array}{l}\text { Meseta Blanca owab sample, } 1305-1450 \mathrm{ft}, 2 / 3 / 59 \text {. } \\
\text { baverage analysis of last } 24.4 \times 10^{6} \text { gallons of water injected 1nto the dis- } \\
\text { posal well, during the } 90-\text { day test ending } 5 / 8 / 60 \text {. } \\
\text { CSwabbed aample from disposal well after } 476,000 \text { gallons had been removed, } \\
10 / 5 / 60 \text {. }\end{array}$} \\
\hline
\end{tabular}


In the process, during that time, the wastewater was high in nitrate but low in sodium and chloride. The water contains small amounts of radioactive uranium, $2{ }^{30} \mathrm{Th}$, and ${ }^{226} \mathrm{Ra}$.

No rate of wastewater production is reported in the references, but bused on the volumes injected it is about $200,000 \mathrm{gpd}$.

When the acid wastewater enters the near-neutral environment of the disposal reservoir, it undergoes marked changes due to neutralization, Ionexchange, and dilution. These changes convert the wastewater to a fluld in equilibrium with the reservolr, with a composition approaching that of the original reservoir fluid.

Neutralization of the acid wastewater causes $230 \mathrm{Th}$, calclum sulfate, and ferric hydroxide to precipitate. Radium-226 and other metal ions are captured by fon-exchange and adsorption by the clay minerals in the reservolr rocks. Incremental dilution at the wetted surface of the reservolr solids occurs throughout the invaded zone.

Determinations of the neutralization capactity of core samples from the disposal reservoir Indicate that $1 \mathrm{cu} f \mathrm{ft}$ of sandstone nettrallzes $389 \mathrm{gal}$ of the injected wastewater to a pH of 7.0. Flood tests of whole cores indicate that the 1on-exchange capacity of $1 \mathrm{cu} f \mathrm{ft}$ of reservolr sandstone is $9.66 \times 10^{-8}$ 8 , or about $9.5 \times 10^{-4} \mu \mathrm{Cl}$ of ${ }^{226} \mathrm{Ra}$.

These experimental results were suistantlated by comparing the analyses of the water injected during a 90-day injection test with analyses of the same water swabbed out of the reservoir (Table 20). A total of 67,474,820 gal of water was injected during the 90-day test. Analyses of a sample taken from $476,000 \mathrm{gal}$ of this iluld that had been swabbed out of the reservo1r showed a reduction in all major chemical and radloactive constituents except magnesium. of the original concentrations of radioactive material, 13.3 percent of ${ }^{226} \mathrm{Ra}$ and less than 1 percent of the natural uranium and $2{ }^{30}$ Th remained in solution, presumably owing to precipitation of uranium and thorlum compounds when the pH changed.

\section{Well Construction and Tedting}

Drilling began on January 11, 1959, and a 110-day period was required to drill, core, test, and complete the well. A $77 / 8-1$. hole was drilled 445 ft into the San Andres formation. This hole was reamed to $121 / 4 \mathrm{ln}$. to a wepth of $85 \mathrm{ft}$, a $95 / 8 \mathrm{ln}$. surface conductor was huns, and coring began.

A total of $2066 \mathrm{ft}$ of continuous $31 / 2-1 \mathrm{n}$. core was cut from a 7 3/4-1n. hole to a total depth of $2511 \mathrm{ft}$. In 75 core runs. This 1ncluded 71 $f t$ of core cut from the Precambrian basement rock. After each core was cut, precise footage and recovery measurements were made and marked on the core, and a detalled megascoplc $10 \mathrm{~g}$ was made. Core aections of 3-1n. length were taken at 2-ft intervals and were canned to preserve their original moloture and physical properties for permeability and porosity determinations. Similar idmples were taken from specific sandstone, shale, and evaporite intervale for other laboratory tests. The remainder of the core was packaged in waterproof cardboard cartons, and all core samples were shlpped to the laboratory. 
The major phase of the laboratory examination of the core consisted of 2105 determinations of permeability and 1211 determinations of porosity. In addition, determinations were made of water content and ion-exchange and neutralization capacities. Binocular examinations, thin section studies, and heavy-mineral and $\mathrm{X}$-ray diffraction analyses were elso made.

During drilling and coring operations, 13 drill-stem tests were attempted on intervals selected on the basis of megascopic examination of the core. Nine were successfuliy completed and four were mlsruns. The nine successful drill-stem tests provided valuable information on formation pressures and gave advance information on the transmissibility of possible disposal zones.

Thirteen intervals in the hole were swabbed for fluid samples from the varfous formations and potent tal disposal zones. These water samples were taken only after sequential analyses of fluid samples for chloride, conductivity, alkalinity, and $\mathrm{pH}$ had stabilized, which indicated that uncontaminated fluld was being removed from the formation. Analyses of these water samples showed that the disposal reservolr contains bricklsh water and that the quality of the formation fluids decreases with depth below the San Andres fresh-water aquifer.

Three electric logs were run when the total depth of the teet hole was reached: sonic-gamma, Induction, and microloz-caliper. These logs, which provided accurate depth measurements for correlation of the core analyses with the casing and perforating operations, supplemented the data obtained from core and drill-ster tests. A drift survey indicated that the hole had a horizontal displacewent of about $4 \mathrm{ft}$ at a depth of $155 \mathrm{ft}$. Numerous other loge were run during the completion of the disposal well to facilitate the casing and perforating operations.

The well was completed into $563 \mathrm{ft}$ of reservolr sandstones in the lower San Ysidro member and the Meseta Blanca member of the Yeso formation. These sandstones have an average porosity of 17.1 percent and an average permeability of 105 millidarcles. Seven thin sandstone beds in the upper abo formation were perforated, but they do not accept fluid, probably because they are discontinuous. The disposal reservolr is separated from the San Andres fresh-water aquifer by an intervening evaporite zone. Core analyses and drillstem tests show that this evaporite zone is an almost impermeable barrier to fluid migration. Both the evaporite barrier zone and the disposal reservoir sandstones are strat 1 graphic units that are recognizable over an area of thousands of square miles.

Prior to the installation of casing, the original test hole was reamed to $171 / 4 \mathrm{in}$. to a depth of $730 \mathrm{ft}$; surface casing was run and set into the upper 10-ft-thick anhydrite bed in the evaporite zone. Th1s casing was 13 3/8 In.-OD, grade H-40, 48 lb per ft seamless steel. All casing collars were spot-welded; mud scratcher, centralizers, and a gulde shoe were run on the casing. Neat portland cement in 100 percent excess was circulated to the ourface to enoure that the casing had a complete cement envelope. The aurface casing was pressure-tested after the remsining hole had been reamed to $1830 \mathrm{ft}$ for the injection casing. 
The infection casing was run from the surface to a depth of $1830 \mathrm{ft}$ in an 11-in. hole. The casing was $85 / 8-1 n$. OD, J-55, 32 lb per ft seamless steel, and was run with centralizers, a casing shoe, and a baffle collar. The baffle collar allowed the bottom 32-ft joint of casing to be left full of cement to plug off the hole below $1830 \mathrm{ft}$, thus preventing the 1dle lower hole from becoming a breeding ground for bacteria and fungl. To protect the infection casing frow corrosion by the acid injection water, casing was installed that had a baked-on Internal coating of a modified phenolic plaptic 7 to 8 mils thick. Further corrosion protection was obtained by using a sulfate-resistant cement composed of equal pnits of Type $V$ portland cement and an inert pozzolan. The injection casing was cemented to the surface.

After completion of the casing operations, a 10-day pump out test was performed on the Meseta Blanca to observe its drawdown and recovery behavior. The Meseta Blanca is the largest single disposal zone in the well, and this was the first opportunity to conduct a practical test on the potential disposal reservoir. The Meseta Blanca was perforated at 2-ft intervals with 108 bullets, each forming a hole of 9/16-in. diameter. These perforations were fractured with fresh-water to ensure unrestricted conmunication between the wellbore and the disposal reservolr. A submersible pump was installed, and a separate probe pipe was run to allow undisturbed measurements of water levels. The pumpout test conslated of measurements of the water levels in the well during drawdown and recovery. The interpretation of these data indicated that the Meseta Blanca was a satisfactory djsposal reservolr and that completion of the well was warranted. About one million gallons of water was pumped from the Meseta Blanca during the test. This water was stored in two earthen reservolrs that were 1 ined with polyethylene $\mathrm{f} 1 \mathrm{~lm}$, for later use in the fraccuring operations.

After fracturing and acid treatment of the injection interval, the hole was cleaned out to a completed total depth of $1796 \mathrm{ft}$. Several short-term injection tests were made with the drill r1g pumps. These and subsequent tests Indicated that fracturing had caused an increase in infectivity eight times greater than that indlcated by core analyses.

After completion of the disposal well on May 1, 1959, all construc$t$ Ion data and test results were submitted to state and federal authoritles, with a request for permiseton to test the well on an operational basis for 90 infection days. Th1s permiseion was granted, and injection began on January $20,1960$.

The infection tests consisted of detalled observations of the behavior of the well under long-term Injection and recovery. Graphical and mathematical analyses of these reservolr pressure data indicated an apparent transmissibility of at least 250,000 millidarcy-ft per centipolse. A pressure barrier within the reservolr was detected at a distance of about $700 \mathrm{ft}$ from the well, colnciding with the surface trace of a fault. No evidence of leakage was found, however, Indicating that the disposal reservolr is loolated from the overlying fresh-water aquifers within the area of the infection pressure point.

Analysis of the distribution of the total injection flow among the varlous perforated zones, by the use of spinner surveys, Indicated that some of the perforations in the upper part of the hole and all of the perforations below $1423 \mathrm{ft}$ were Idle. An unsuccessful attempt was made to open these idle 
intervals by reperforating them with 90 bullets in the upper zones and 17 jets in the lower zones.

After the 90-day test, inspection of the well revealed that the acid infection water had begun to corrode the $85 / 8-i n$. injection casing. The internal plastic lining had been extensively damaged by the work done inside the casing during and after installation. To halt this corrosion and to provide further protection to the fresh-water aquifers, an attempt was made to fabricate a liner from 7-in. OD, 1/4-in.-thick ABS (acrylonitrile-butadienestyrene) plastic plpe. After considerable trouble and expense, the plpe was Installed in the hole, but it ruptured under the pressure of cementing operations and had to be removed. To solve this problem, a stalnless steel liner was finally installed and cemented to a depth of $905 \mathrm{ft}$ before routine operational infection was begun. Th1s 1iner was Type 316 , Schedule 10 welded seam, stainless steel, 6 5/8-1n.-OD pipe. A 3/8-1n. stainless steel probe pipe was joined to this liner at a depth of $278 \mathrm{ft}$. The liner and probe pipe were butt-welded as they were run 1nto the hole, and were cemented to the surface with sulfatereslotant cement and were pressure-tested.

\section{Surface Fac1lities}

The surface Installations in the completed disposal system consist of a decanter, filter plant, and a pipeliue to the well. The decanter is a wooden box $4 \times 120 \mathrm{ft}$, which was erected on foundations in the tailing pond adjacent to the filter installations. The top of the decanter is ralsed as the water level of the pond rises as a result of displacement of liquid by talling solids. The decanted water is lifted from pond level by a turbine pump and is filtered alternately through one of two circular leaf filters. This filtrate then passes through a small surge tank from which a centrifugal pump forces it through a metering manifold and $1.4 \mathrm{miles}$ of $12-\mathrm{in}$. rubber-lined pipeline in a lift of $90 \mathrm{ft}$ to the disposal well. The water enters the well by free fall in a sealed pipeline-well connection that prevents the entrainment of air. All filter, pump, and pipeline equipment are elther rubber-ilned or stainless steel.

During che initial stages of injection, the filter feed and the wellbore were treated with a total of 9000 lo of citric acid crystals to sequester the lons present in relatively high concentration in the wastewater. This temporary treatment prevented the precipitation of iron in the immediate vicinity of the wellbore, where reservolr permeability is the most critical.

In practice, the filter product has a turbidity of about $0.1 \mathrm{ppm}$ suspended solids on the silica scale; a maximum turbidity of $0.4 \mathrm{ppm} 1 \mathrm{~s}$ allowable. This limit was determined by flood tests of core sfecimens from the disposal zones.

The wastewater 18 continuously treated with 20 ppm of sodium polyphosphate to retard the precipitation of calcium sulfate. Since the initial schedule of adding $4 \mathrm{ppm}$ of copper sulfate for control of bacteria and fungi was not completely effective, it was necessary to add formaldehyde in 1962 to remove microblological growths from the supply ilne. 


\section{Monitoring}

The program for monitoring the disposal system is continuous and consists of three phases: (1) direct observation of the behavior of the disposal well, (2) sampling the major fresh-water aquifer in the immediate vicinity of the well, and (3) routine sampling of regional fresh-water sources.

Daily measurements are made of the operating water level in the disposal well, and occaslonal recovery measurements are made when the well is shut down. This monitoring seeks to detect trends that would indicate interformational leakage. Also, water levels have been monitored in six wells since 1956, and in a seventh, near the disposal well, since 1960 . Seasonal fluctuations of 5 to $10 \mathrm{ft}$ in water levels were typical through 1961 in all the wells (West 1972). The highest levels were in early spring, and the lowest levels were in late summer or early fall. These fluctuations are readily correlated with the general effect on the water table of groundwater pumping in the area for irrigation. If leakage from the tailings pond affected water levels in the wells, these effects were masked by the stronger effects of pumping. Two of the wells had net declines in water level from 1956 to 1961; the others remained fafrly constant except for the seasonal fiuctuations. Water levels rose almost continuously, with only slight seasonal fluctuations, in all the wells from the autumn of 1961 through 1965. These r1ses in water level, which coincided with a significant reduction in groundwater irrigation pumping in the area, started 8 years after use of the tailings pond began.

In addition to monitoring the water level, the Anacunda Co. has monitored the chemical and radiochemical quality of water monthly in 20 wells, bimonthly in 25 wells and springs, and semiannually in 2 wells. Samples from the tallings pond, the power-house pond, and the laboratory pund were analyzed monthly. Sampling points were selected to provide good areal distribution. Concentrations of sodium,sulfate, chloride, and nitrate have been found to increase significantly in water from wells that tap the San Andres 11mestone in the vicinity of the tallings pond and the disposal well (West). Since this change in water quality began before the disposal well was drilled, because of leakage from the tailings pond, any hanges caused by the well would be difficult to detect.

West (1972) concludes that "Leakage of water upward into the Glorleta sandstone and the San Andres limestone has not been detected, but the effects of upward leakage could be masked by fluctuations of water levels caused by pumping In the general area of the disposal well and by prior contamination of water In the San Andres by leakage of mill effluent from the tallings pond." He further states that "When all data are considered, well injection of the mill effluent appears to be the most satisfactory method of effluent disposal that is economically feasible."

\section{Regulation}

According to varlous accounts, the Anaconda well was initially Ilcensed by both the New Mexico Department of Public Health and U.S. Atomic Energy Comission.

Lynn and Arlin (1962) reported that "At the end of the 90-day (1nfection) test, a final report of all phases of the proposed deep well diuposal 
program was submitted to the New Mexico Department of Public Health and the U.S. Atomic Energy Commission, with a request for permission to begin routine operational injection of the mill wastewater. Conditional permission was granted by these agencies, and routine injection was begun on December 14, 1960." In a letter from the New Mexico Department of Public Health (May 22, 1964) Mr. Charles G. Caldwell stated that "The New Mexico Department of Public Health in conjunction with the New Mexico State Radiation Advisory Engineer, and the U.S. Geological Survey Investigated and permitted deep well injection of these liquid wastes, as very difficult problems existed in regard to waste disposal at this urantum processing mill." The well is presently operating under licensing furisdiction of the state of New Mexico only. Although the US NRC is in frequent communication with supervisors of well operation, a licensing arrangement is not at present in effect between the company and NRC on this well (Chitwood).

\section{Costs}

Lynn and Arlin (1962) reported that the total cost (1962 dollarg) to the Anaconda Company well, excluding surface facilities, was $\$ 364,800$. They believed, however, that a second well could be constructed at the same location for about $\$ 150,000$.

The actual experfenced 1 n.52 cost for the Anaconda well was $\$ 145$ per foot. The ENR index can be used to estimate that this 1962 experfenced cost was about 20 times the cost of an oll or gas well constructed in the same year, and it is nearly 10 times the cost of constructing the average oil and gas well In 1973 (Fig. 30).

In analyzing this, Lynn and Arlin stated that "Because the present disposal well was orfginally drilled as a test well, the total costs are not readily applicable to a simflar well constructed under less demanding circumstances. However, future attempts to develop disposal walls in unproven areas will meet with simflar problems." A detalled breakdown of costs for the Anaconda well is given in Table 21 .

Lynn and Arlin also reported the 1962 operational costs for the fllter plant as $\$ 0.22$ per thousand gallons of water treated, of which $\$ 0.10$ was for chemicals and $\$ 0.12$ for labor.

\section{B. Kerr-McGee Corporation (Sequoyah) Uranium Hexafluoride Production Plant}

\section{General D18cussion}

The Kerr-McGee Sequoyah fac1lity 1s located on a 2100-acre tract In western Sequoyah County, Oklahoma. The plant produces uranium hexafluoride from yellowcake (normally ammonium diuranate), a uranium ore concentrate produced at mills in the western United Stater or Canada. A major waste stream produced during the uranium ore processing is that frow the uranium extraction step. The waste atream from the extraction process, or raffinate, is composed primarily of amonium nitrate, nitric acid, metallic oalts, and small quantities of uranium and 1 ta radioactive decay products.

The original design of the plant provided for discharge of the raffinate and posatbly other chemical wastes into a deep well at the plant site. 
Table 21. Costs of Construction and Teating of the Anaconda Company D1sposal Well System (Lynn 1962)

\begin{tabular}{|c|c|c|}
\hline Disposal Well Construction & $\begin{array}{r}\text { Total } \\
\text { Cost }\end{array}$ & $\begin{array}{l}\text { Cost per } \\
\text { L1n. Ft }\end{array}$ \\
\hline 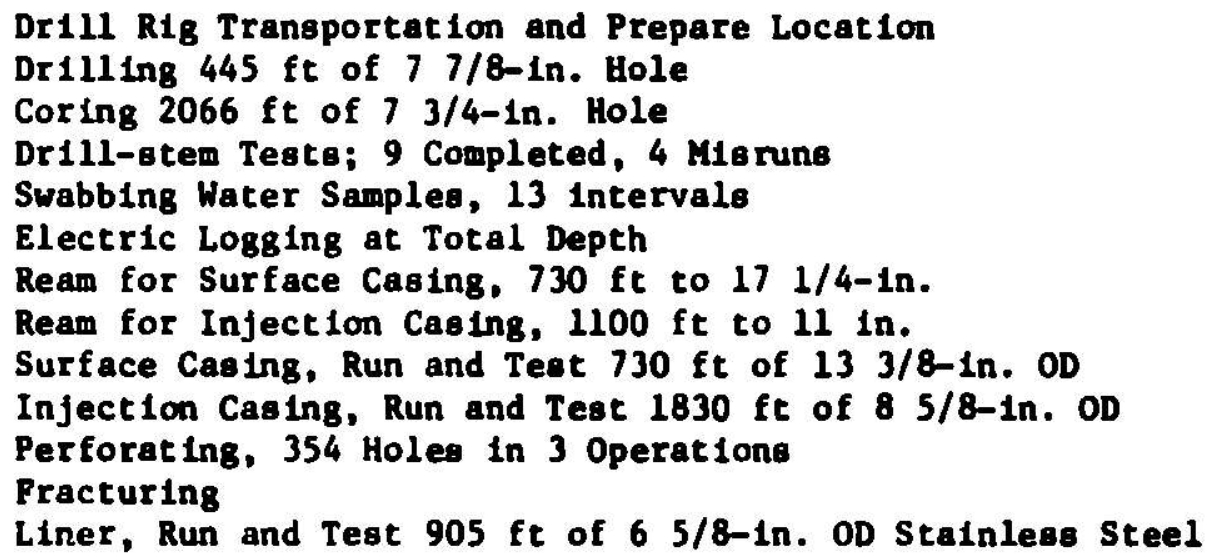 & $\begin{array}{r}13,400 \\
3,700 \\
69,500 \\
13,800 \\
12,400 \\
2,600 \\
8,000 \\
4,500 \\
17,100 \\
35,900 \\
5,300 \\
30,300 \\
19,400\end{array}$ & $\begin{array}{r}10.97 \\
4.11 \\
23.48 \\
19.64\end{array}$ \\
\hline otal, & 235,900 & \\
\hline
\end{tabular}

Disposal Well Testing Operations

\begin{tabular}{|c|c|c|}
\hline $\begin{array}{l}\text { Pump-out Test } \\
\text { Anslyses of Co } \\
90 \text { Day Test: }\end{array}$ & 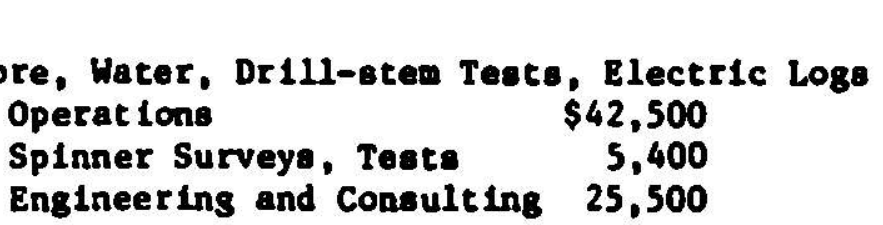 & $\begin{array}{r}\$ 15,700 \\
15,300 \\
\\
73,400 \\
\end{array}$ \\
\hline
\end{tabular}

Miscellaneous Construction

Plastic LIner, $890 \mathrm{ft}$ of 7-in. ABS, Run and Rewove Acldizing Treatments, Two

$\$ 21,200$

$\$ 23,82$

Total. Miscellaneous Construction

3,300

24,500

\section{Surface Inatallations}

Decanter

Filter Plant

Pipeline. $7400 \mathrm{ft}$ of 12-1n. Rubber-lined P1pe

Monltor Wall, 628 ft Total Depth, Caed to 5 1/2-1n. OD

Total, Surfece Instaldet lone

Grand Total. Deop Well Dlepoeal syete.
$\$ 20,900$

98,700

73,000

4,600

$\$ 9.83$

197,200

$\$ \$ 62,000$ 
The well was actually drilled and completed, probably in 1966, at the t1me the plant was constructed, but an AEC 11cense for the well was not requested until May 1970. The AEC refused the application In October 1970, but allowed the Company to withdraw the application without prefudice. An amended application was filed May 1972, but a license was again denied November 20, 1972. Th1s decision was reaffirmed in March 1973. On Apr11 5, 1973, the Kerr-McGee Company requested a hearing by the Atomic Safety and Licensing Board. A prehearing conference was held July 17, 1973, and the hearing on October 15 and 16, 1973. After consideration of the evidence, the Board ordered tha: the 11 cense be dented on January 18, 1974.

All information given here was obtained from publicly accessible DOCKET documents (Kerr).

\section{Site Geology}

The Kerr-McGee Sequoyah facility is on the southwest flank of the 0zark uplift to the north of the Arkoma basin (F1g. 23). Drilling of the test well at the plant showed that a total thickness of about 3100 feet of sedimentary rocks of Pennsylvanian to Cambrian age is present, underlain by Precambrianage grantific basement rocks. The rock sequence is describ ad in Table 22.

Virtually all of these rocks are nonporous and impermeable, unless fractured. Exceptions are sandstones in the basal Atoka and in the Simpson and several intervals in dolomites of the Arbuckle Group. Rock samples, geophysical logs, and well testing indicated the presence of porous and permeable zones in the Arbuckle, and that interval was proposed for waste injection.

As mentioned above, the site is on the southwest flank of the Ozark uplift, and the sedimentary rocks dip reglonally 2 to 3 degrees to the southwest, except in the vicinity of faults. Surface and subsurface gerology and testing of the reservolr Indicated that the plant is bounded by a least 2 major faults and posatbly by 4. The interpretation presented by the Company showed faults 1100 feet northeast, 1 mile southeast, 6 miles northwest, and 6 mlles southwest the well, thus enclosing it completely. These faults were interpreted as being barriers to fluld movement and thus creating a favorable situation whereby injected wastewater could not leave an enclosed fault block.

Fresh groundwater in the area is limited to alluvial deposits in the stream valleys and to the Atoka formation. The Atoka is generally a very poor producing aquifer with ylelds of, at most, a few gallons per minute of water of low quality.

Natural $8 a s$ and coal are present in the subsurface in the area, but the nearest 8 as production $1814 \mathrm{~m} 1 \mathrm{les}$ to the west and the nearest coal depos1 ts are about 12 miles to the southeast.

Several oll and gas test wells had been drilled in the area around the Kerr-McGee plant, and data from these wells and the Kerr-McGee well were ued to prepare a hydrodynamic evaluation of the area. The avallable information Indicated that fluids in the Arbuckle are essentially in hydrostatic equilibrium. That 18, there is little or no natural movement of formation fluids at present. 
Table 22. Rock Sequence ${ }^{a}$ at the Site of the Waste Disposal Well Constructed at the Kerr-McGee Co. Uranium Hexafluoride Production Plant

\begin{tabular}{|c|c|c|c|}
\hline Age & $\begin{array}{l}\text { Rock Unit } \\
\text { Name }\end{array}$ & $\begin{array}{c}\text { General } \\
\text { Lithology }\end{array}$ & $\begin{array}{l}\text { Thickness } \\
\text { (ft) }\end{array}$ \\
\hline Recent & --- & sand and gravel & 15 \\
\hline Pennsylvania & Atoka & $\begin{array}{c}\text { shale, s1ltatone, } \\
\text { sands tone }\end{array}$ & 375 \\
\hline Pennsylvania & Wapanucka \& Hale & limestone, shale & 165 \\
\hline Mississippian & Pitkin \& Fayetteville & limestone & 190 \\
\hline Mississippian & Chattanooga & shale & 75 \\
\hline $\begin{array}{l}\text { Devonian \& } \\
\text { Silurian }\end{array}$ & Hunton & limestone & 200 \\
\hline \multirow[t]{3}{*}{ Ordovician } & Sylvan & shale & 40 \\
\hline & Viola & limestone & 50 \\
\hline & Simpson & $\begin{array}{c}\text { shale, sandstone, } \\
\text { limestone }\end{array}$ & 335 \\
\hline $\begin{array}{l}\text { Ordovician- } \\
\text { Cambrian }\end{array}$ & Arbuckle & dolomite-sandy at base & 1665 \\
\hline Precambrian & & granite & \\
\hline
\end{tabular}


The region in which the plant is located is tectonically stable, which is Indicated by the fact that the nearest recorded earthquake epicenter is 40 miles to the south. Therefore, the probability of initiating earthquakes by fluid injection and of sustaining damage to injection facilities by earthquakes was considered to be very low.

\section{Wastewater Evaluation}

The Kerr-McGee Company proposed to Inject 90 to $125 \mathrm{gpm}$ of a wastewater resulting from a mixture of 11 different waste streams, part of which are only produced intermittently. Table 23 characterizes three of the main waste streams. According to the Company, the waste could be expected generally to consist of 90 percent of waste composition number 1, 9-10 percent of number 2 , and the balance of number 3 .

The waste proposed for injection is extremely corrosive because of the acids it contains ( $\mathrm{pH} \cong 1$ ) and it was not planned to neutralize it before injection. The only pretreatment planned for the waste was mixing of the various waste streams in a 2500 gal surge tank. The raffinate was to be prepared, prior to its release to the surge tank, by removing as much as possible of the organic solvent (tributyl phosphate) and excess uranium. Removal of the solvent was planned because it is detrimental to the lining to be used in the injection tubing. Excess uranium was to be removed for economic reasons and to minimize the release of radioactivity.

Laboratory tests demonstrated the compatibility of wastewater and formation water. Also, no reduction in permeability was measured after a formation core was flushed with synthetic raffinate fluids. In fact, the laboratory study indicated that the waste fluids wculd slightly increase permeability.

\section{Well Construction and Testing}

The Kerr-McGee Sequoyah disposal well was drilled with rotary tools to a total depth of $3122 \mathrm{ft}$ to the basement granite formation. The following intervals of the Arbuckle formation were diamond coied:

$\begin{array}{ll}\text { Core \#1 } & 1452-1477 \mathrm{ft} \\ \text { Core \#2 } & 1737-1743 \mathrm{ft} \\ \text { Core \#3 } & 1912-1925 \mathrm{ft} \\ \text { Core \#4 } & 2294-2312 \mathrm{ft} \\ \text { Core \#5 } & 3021-3032 \mathrm{ft}\end{array}$

Also, the following Schlumberger logs were run:

Induction-electrical Survey from 133 to $3121 \mathrm{ft}$

Compensated Formation Density from 498 to $3128 \mathrm{ft}$

Sidewall Neutron Porosity from 498 to $3126 \mathrm{ft}$

Lithology Identification - Synergetic Log 
Table 23. Composition of Wastes Proposed for Deep-Well Disposal at the Kerr-McGee Co. Uranium Hexafluoride Production Plant

\begin{tabular}{|c|c|}
\hline \multicolumn{2}{|c|}{ Nonradioactive } \\
\hline \multicolumn{2}{|l|}{ Waste Composition 1} \\
\hline $\begin{array}{l}\text { Hydrofluoric Acid } \\
\text { Water }\end{array}$ & $\begin{array}{r}2 \% \\
98 \%\end{array}$ \\
\hline \multicolumn{2}{|l|}{ Waste Composition 2} \\
\hline $\begin{array}{l}\text { Nitric Acid } \\
\text { Sulfuric Acid } \\
\text { Phosphoric Acid }\end{array}$ & $\begin{array}{l}10 \% \\
2.5 \% \\
0.25 \%\end{array}$ \\
\hline $\begin{array}{l}\text { Hexane } \\
\text { Tributy? Phosphate } \\
\text { Solids } \\
\text { Water }\end{array}$ & $\begin{array}{l}0.1 \% \\
\text { Trace } \\
0.51 b / g a l \\
\text { Balance }\end{array}$ \\
\hline \multicolumn{2}{|l|}{ Waste Composition 3} \\
\hline $\begin{array}{l}\text { Sodium Hydroxide } \\
\text { Potassium Carbonate } \\
\text { Fluorides (soliris) } \\
\text { Water }\end{array}$ & $\begin{array}{l}10 \% \\
10 \% \\
11 \mathrm{~b} / \mathrm{gal} \\
\text { Balance }\end{array}$ \\
\hline \multicolumn{2}{|c|}{ Radioactive } \\
\hline Isotope & Average Conc. $\left(\mu \mathrm{C}_{1} / \mathrm{ml}\right)$ \\
\hline U natural & $15 \times 10^{-5}$ \\
\hline Thor1um-234 & $4.5 \times 1.0^{-2}$ \\
\hline Thorium-230 & $6.0 \times 10^{-4}$ \\
\hline Radium-226 & $2.1 \times 10^{-5}$ \\
\hline
\end{tabular}


After logs were run the 7-1n. casing was cemented to $1619 \mathrm{ft}, 300 \mathrm{ft}$ below the top of the Arbuckle. The 7-in. casing was pressure tested at 1000 psi for 30 min with no pressure decline. The drilling mud in the well was displaced with fresh water and the Arbuckle formation was swab tested inrough 2 7/8-1n. tubing set at $3089 \mathrm{ft}$. Salt water was swabbed for $8 \mathrm{hr}$ ai a rate of 79 barrels ( $2500 \mathrm{gal}$ ) of water per hour. The fluid level during swabbing remalned fairly constant at a depth of $250 \mathrm{ft}$ below ground level. A sample of the formation water was retalned for analysis. Twelve hours after swabbing was terminated, the fluid level was $50 \mathrm{ft}$ below ground level.

An Initial injection test was run, then the Arbuckle formation was acid-treated and a second test was run. After acld treatment, the injection pressure required for a given flow rate was substantially reduced.

Figure 32 is a schematic sketch of the Sequoyah injection well. The

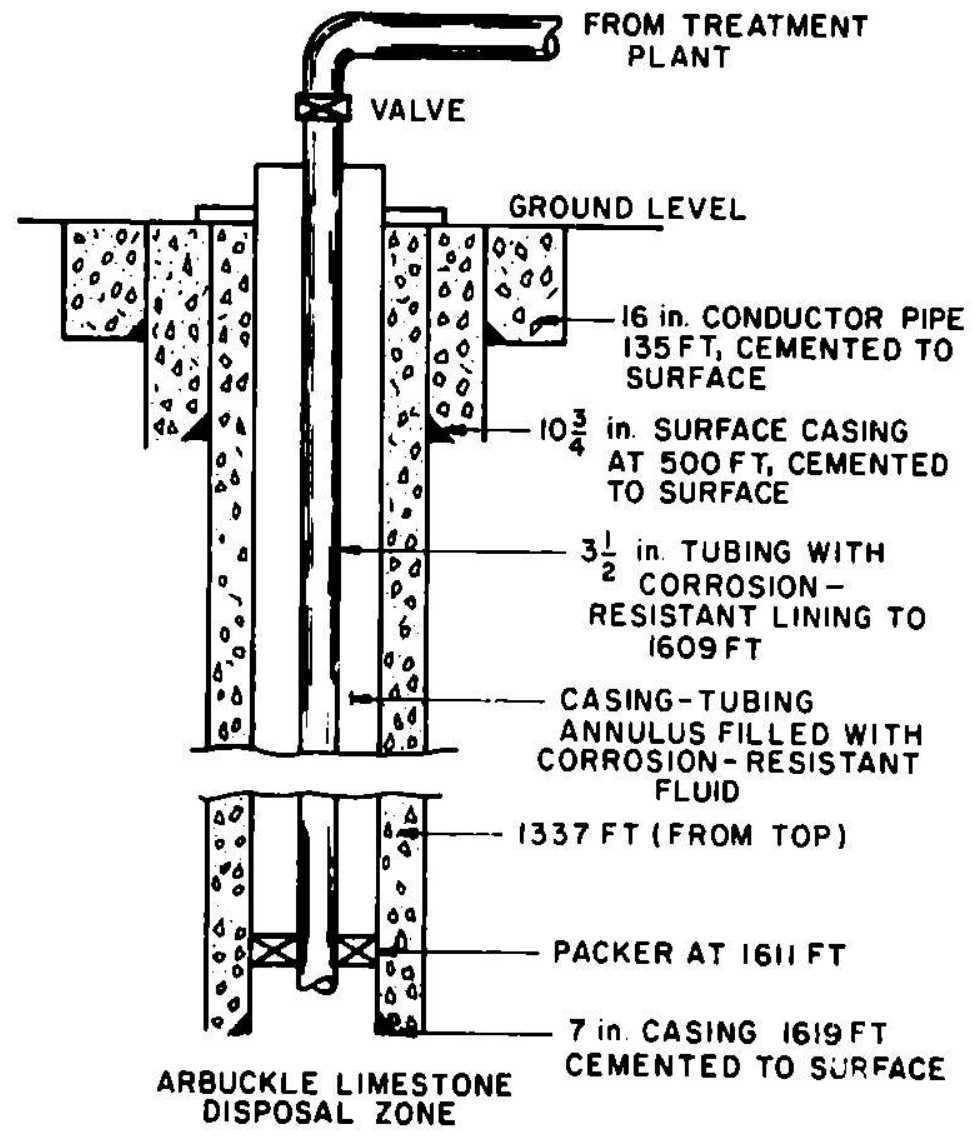

ilig. 32. Schematic Sketch of Well Proposed for Waste Infection at Kerr-McGee Sequoyah Facility.

well was cared and cemented according to the schedule shown in Table 24 . The bottom two foints of 7-in. casing are Carpenter 20 alloy steel with a Howco guide shoe on the bottom and a float collar at the top of the second joint. The bottom joint is equipped with two centralizers and $s 1 x$ Genoco Collflex wall cleaners. Two centralizers were also run on the third, fifth and seventh Joints, and 15 additional centralizers were spaced at 90-ft intervals above the seventh folnt. The bottom seven foints of 7-1n. casing are Ruff-Coted. 
Table 24. Schedule for Casing and Cementing the Waste Disposal Well at the Kerr-McGee Uranium Hexafluoride Production Fac1lity

\begin{tabular}{|c|c|c|c|c|c|}
\hline Casing Size & $W+/ \mathrm{ft}$ & Grade $^{a}$ & Type & Depth & Cement \\
\hline 16 In. OD & $551 \mathrm{~b}$ & H 40 & ST\&Cb & $135 \mathrm{ft}$ & $\begin{array}{l}200 \text { sacks regular with } 2 \% \\
\mathrm{CaCl} \text { and } 1 / 4 \text { lb Flocele } \\
\text { per stack. Cement cir- } \\
\text { culated to surface. }\end{array}$ \\
\hline $103 / 4-1 n$. OD & $32.751 \mathrm{~b}$ & H 40 & $\operatorname{sTaa^{b}}$ & $498 \mathrm{ft}$ & $\begin{array}{l}350 \text { sacks HLC with } 2 \% \\
\text { CaCl. Cement circulated } \\
\text { to surface. }\end{array}$ \\
\hline 7 in. OD & $\angle 01 \mathrm{~b}$ & J 55 & $\operatorname{stsc}^{b}$ & $1619 \mathrm{ft}$ & $\begin{array}{l}400 \text { sacks HLC with } 10 \text { lb } \\
\text { G1lsonite per sack plus } \\
100 \text { sacks 50-50 Pozmix } \\
\text { w1th } 9 \% \text { CRF-Z and } 10 \% \\
\text { CaCl. Cement c1r- } \\
\text { culated to surface. }\end{array}$ \\
\hline
\end{tabular}

${ }^{a}$ American Petroleum Ingtitute designation based on tensile strength.

babreviation for "short thread and coupling." 
The injection tubing is $31 / 2-1 \mathrm{n} .-0 \mathrm{D}, 9.3 \mathrm{lb}, \mathrm{J} 55$, EuE tubing internally coated with Plastlcap $600 \mathrm{PCV}$. The tubing is set in a Baker Model A tension packer set at a depth of $1611 \mathrm{ft}$. The packer $1 \mathrm{~s}$ internally and externally cuated with Plasticap 600 PVC. The casing-tubing annulus is filled with 45 barrels of fresh-water with an additive of 10 gallons of Aquaness Cronox 609 . The wellhead equipment consists of a tubing hanger and a 2000-1b-vorkingpressure Cameron flange-type 3-in. plug valve. The tubing head is internally coated with polypropylene.

It is interesting to note the similarity between the Sequoyah well and the design suggested in Section IV for a well to infect LLAW. The casing string sizes are the same, 7-in. OD for the injection string and $103 / 4 \mathrm{in}$, for the surface casing. The injection tubing in the Kerr-McGee well is larger (3 1/3-1n. OD) than the $27 / 8-i n$, OD tubing suggested for LLAW, but the flow rate in the Kerr-McGee well was expected to be 90-125 gpm as compared with a maximum of $35 \mathrm{gpm}$ assumed in the design used in Section IV. Casing in the Kerr-McGee well was cenented to the surface, and a packer was used to closejoff the casing tubing annulus, as recommended in Section IV. The corrosion protection steps suggested in Section IV are also included in the well design: plastic-lined injection tubing, corrosion resistant packer, corrosion-resistant materials for the casing below the packer, and corrosion-resistant cement. Th1s protection would have been essential since an unneutralized acld wastewater was to be infected.

The inftial Kerr-McGee proposal was based on the infection testing described above. After initial rejection of the Company's application, a consulting firm was retained and additional formation testing was performed. On the basis of the tests, a computer model of the reservoir was formulated and predictions were made of the effects of injection. It was during this study of the reservoir that the two additional faults in the area were postulated, as previously described in the geologic description of the area.

\section{Surface Factlities}

The only surface facilities planned for the system were flow lines, a surge tank, monitoring and sampling equifment, and injection pumps. Two large retention basins would be avallable for holding of waste in the event of a well shutdown.

\section{Monitoring}

Extensive monitoring of the shallow groundwater and surface water in the area was planned, but no monitor well was to be constructed in the Arbuckle formation.

\section{Regulation}

The general history of the AEC regulatory actions has been reviewed (Kerr). The refection of the Kerr-McGee application was bised on technical details too lengthy and couplex to completely review here. Hiwever, several issues of controversy debated before an Atomic Safety and Licensing Board are summarized (AECR). 
as follows:

The main conclusions of the Atomic Safety and Licensing Board were

A. Although the general principle of deep well disposal of Liquid waste matter, which may be acceptable in some cases, was not an issue in this proceeding, the Board did consider and conclude that with respect to the deep-well disposal of the type of l1quid wastes involved here, there must be a showing constituting reasonable assurance of the safety of such disposal to the public.

B. After a careful review of all evidence of record, the Board concluded:

1. "The Applicant was not able to show that the Applicant's equipment, facilitles, and procedures proposed for use pursuant to the requested amendment are adequate to protect the health and minlmize danger to life or property.

2. The Applicant was not able to show that the issuance of the amendment would not be inimical to the health and safety of the public."

The principal difficulties in this case were related to the falrly complex nature of the geology and subsurface hydrology, which made it difficult, if not impossible, for Kerr-McGee to prove to the Board's satisfaction that no health and safety hazard was involved.

C. Nuclear Fuel Services, West Valley, New York

1. General Discussion

Commercial fuel reprocessing was begun at Nuclear Fuel Services, Inc., West Valley plant during April of 1966. Starting about that time, low-level liquid wastes containing slight amounts of radioactivity were discharged from the facility into surface streams at a controlled rate to comply with standards governing radioactive contamination in unrestricted areas. On May 31, 1968, the Division of Materials Licensing, USAEC, requested NFS to prepare a proposal describing the scope and schedule of plans to achleve a significant reduction in the levels of radioactivity discharged to surface waters from the West Valley plant. One alternative considered by NFS was subsurface injection. Information in this section is based principally on reports concerning the NFS site from files of the AEC and on general geologic studies of the New York area that were cited in Section III.

\section{Site Geology}

No deep well has yet been constructed at the NFS Plant s1te; therefore, subsurface geologic conditions are inferred, using the methods described In Section III. The plant site is in Cattaraugas County, New York, at the northern end of the Appalachian synclinal basin (F1g. 9, 11, and 23). Strata in this area dip southeast at about $50 \mathrm{ft}$. per mile or about one-half degree. Figure 33 is an east-west geologic cross section that passes along the southern border of Cattaraugas Ccunty, about $30 \mathrm{mfles}$ south of the plant. The plant would be toward the west side of the flgure. Rocks shown in the cross section are the same as would be found at the plant site; with Devontan age shales at 

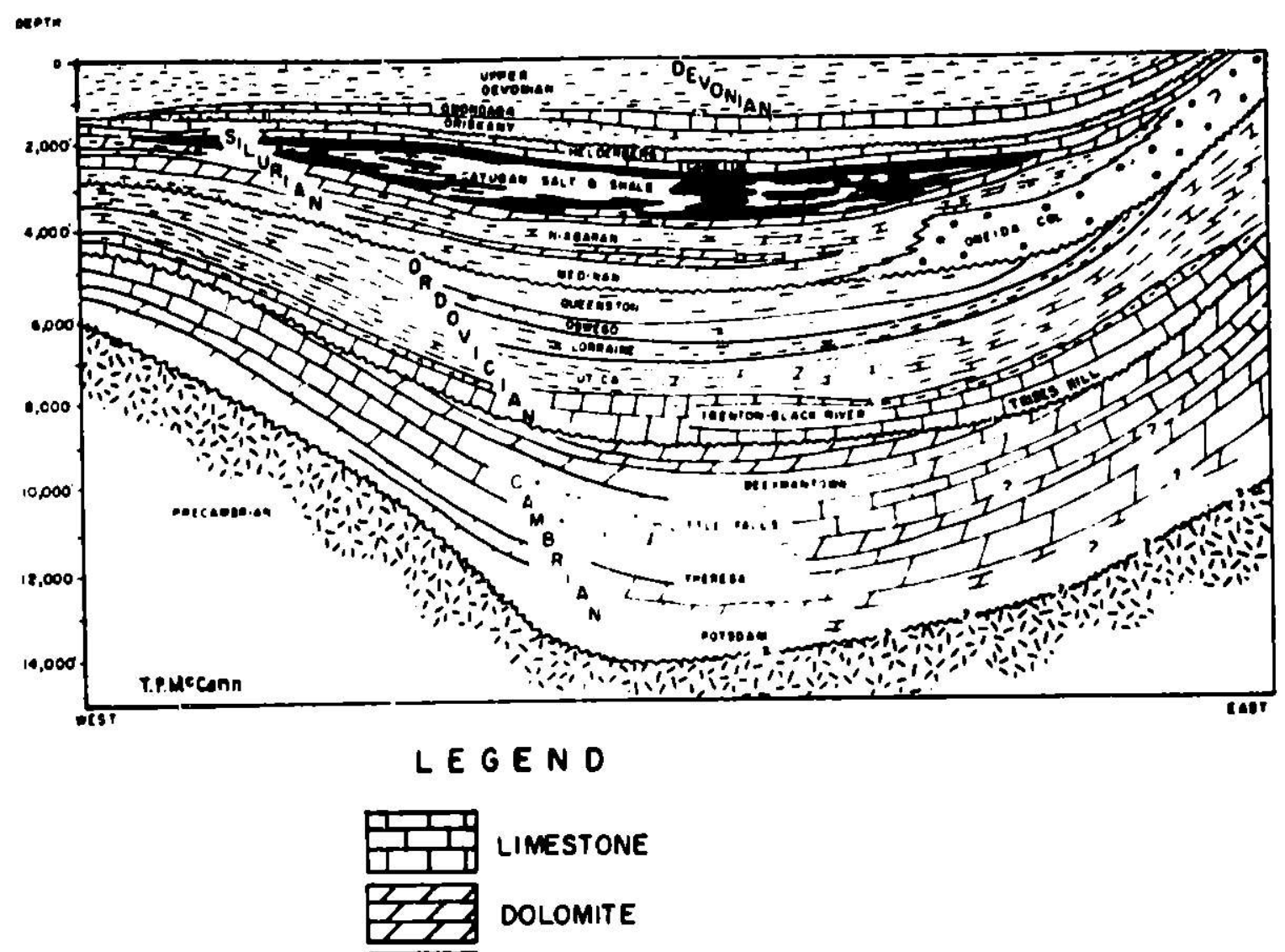

$\left[\begin{array}{r}0 \\ 0\end{array}\right]$ SANDStone U conglomerate

$=-\div$ SHALE a SILTSTONE

SALT a EVAPORITES

Fig. 33. Diagrammatic Cross Section Along the 42nd Parallel, Western New York. Not Drawn to Scale (McCann).

the surface. The total thickness of sedimentary rocks at the plant site is projected to about $6500 \mathrm{ft}$. Consolidated rocks at the site are overlain by glacial till which may be several hundred feet thick.

As shown in Fig. 33, Devonian, Silurian, and Upper Ordoviclan strata are predominantly clastic, with some carbonates and evaporites present in the Lower Devonian and Silurian sections. The Middle and Lower Ordovician and Cambrian rocks are predominantly carbonate, but include some clastics. In particular, the Potsdam and lower Theresa formations comprise a basal sandstone unit that is lithologically equivalent to the Mt. Simon formation mentioned frequently in Section III.

Of the formations present in the subsurface at the plant site, the Theresa-Potsdam basal sandstone unit would be the most desirable for wastewater infection. It is at the very bottom of the stratigraphic sequence and would be conilned by over $5500 \mathrm{ft}$ of relat ively impermeable strata. According to recent, as yet unpublished, studies (Kreldler), this unit should be at 
least 200-ft thick. Unfortunately, porosity and permeability in this sandstone interval tend to be low in wells that have penetrated it in western New York and northeastern Penusylvania. The basal part of the Potsdam, however, is reported to be extremely porous and permeable (McCann). Shows of oil and gas and flows of salt water have been encountered in the Theresa and Potsdam formations, but only one commercial gils field has been developed in the Potsdam, that being in northern Onondaga County. The nearest deep well presently existing that has penetrated the Theresa-Potsdam interval is about 14 miles northeast of the plant.

The area surrounding the NFS Plant site is almost devold of known structural geologic features. The nearest known significant feature is the Clarendon-Linden [ault, which is probably not closer than 25 miles. This fault is a rigional one that has been suggested as being a possible focus of selsmic activity. Lts distance from the plant makes it unlikely that significant pressure increases caused by the well would reach the fault, particularly if an objective in well operat in is minimizing these effects.

Fresh groundwater occurs only i": the glacial deposits and in the upper few fect of the Devonian age shales that directly underlie them. If injection were directed into the Theresa-Potsdam interval, at least $5500 \mathrm{ft}$ of sedimentary rocks, mostly impermeable ones, would separate the disposal interval from fresh water. Water in formations below the Devonian age shales is all quite saline, and brines from the Silurian age salt deposits are used commercially in northern New York.

3. Design and Specifications of the Propused Disposal Well at the Nuclear Fuel Services Plant (DOCKET 50201-28).

Figure 34 shows a sketch of the cross section of the proposed well, and sume of its specifications ire summarized below:

\section{Cementing}

A 4-ft. Calseil plug will be placed on the top of the formation bridge plug to prevent the disposal formation from being cemented up during centent ing of the 7-in. casing.

The 7-in. casing is to be cemented to a depth of $6500 \mathrm{ft}$ in an 8 3/4-in. hole, us ing 900 sacks of 50-50 Pozmix cement-86\# CFR-2 (to denstiy the last 100 sacks), with 72 hr wait ing con cement.

Fluid shall be circulited through each string of casing priur to cemerting. The fluld circulated before the cement slurry is added, shall contaln a sufficlent qua it ty of Quadrofas-type suitable friction reducer additive. Quadrofas is acceptable as an additive. If cement volumes recede from the surface during the setting time, the contractor shall grout these intervals through a small pipe run in the imnular space.

\section{Circulat ing Medl ums}

willi alr.

The $171 / 2-1 n$. surface hole may be drilled with fresh-water gol or 


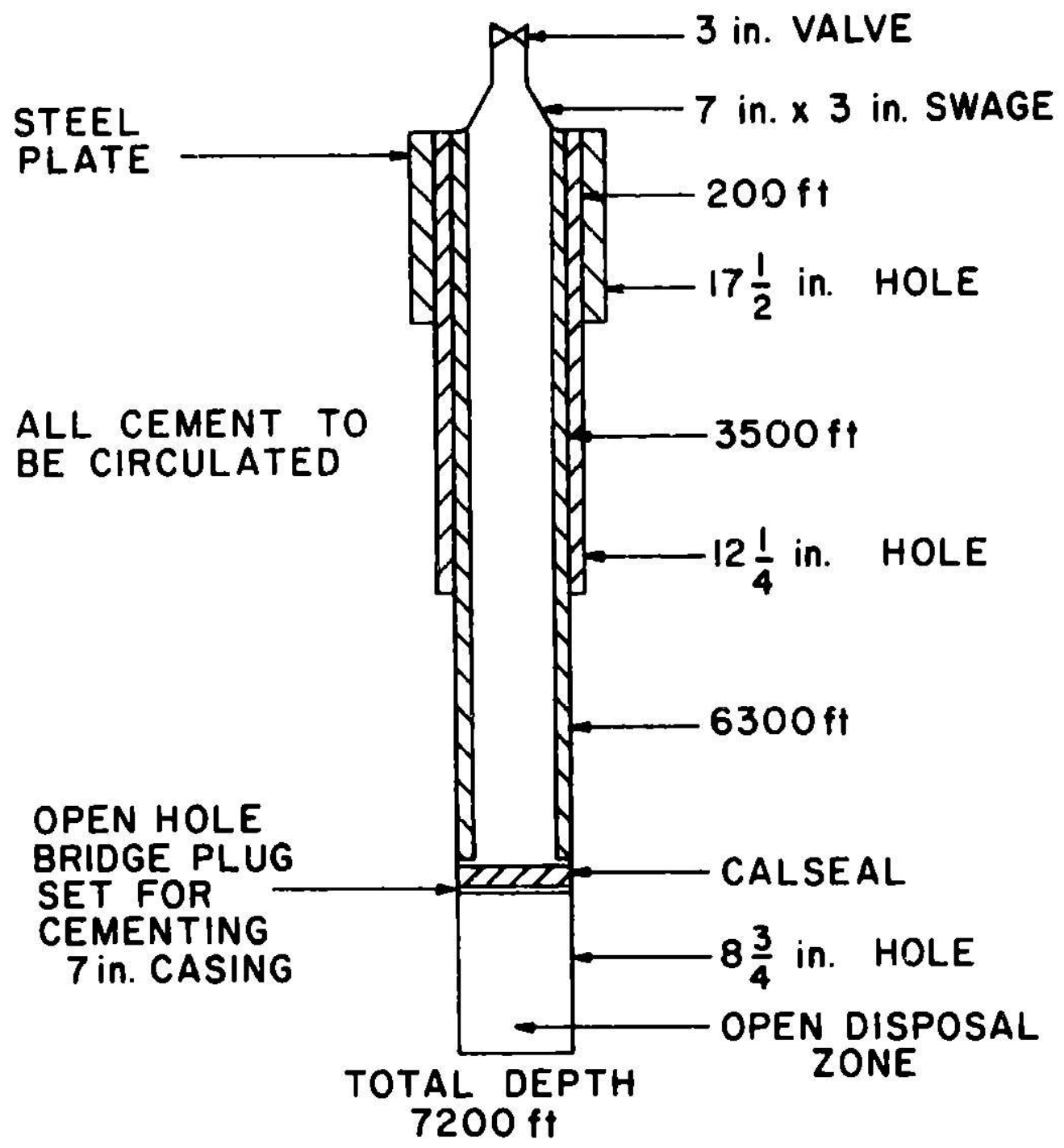

Fig. 34. Sketch of Disposal Well Proposed for the Nuclear Fuel Services Plant (DOCKET-50201-28).

The 12 1/4-in. hole will be air drilled. If it becomes necessary to convert fluid, brine will be used. Salt brine concentrations will be 100,000 to $200,000 \mathrm{ppm}$. No salt water gel or lost circulation material will be used during the drilling of the $83 / 4-1 n$. hole without permission of the engineer.

\section{Stralght Hole Speciflcations}

From 0 feet - 3500 feet (maximum distance between surveys of 100 feet) the maximum change of angle between any two consecutive surveys will be $1^{\circ}$. The maximum deviation from the verical will be $4^{\circ}$.

From 3500 feet to the total depth (maximum distance between surveys of $100 \mathrm{feet}$ ) the maximum change of angle between any two consecutive surveys w11l be $1^{\circ}$. The maximum deviation from the vertical will be $7^{\circ}$. 
Formation Sample Collection

Two complete sets of formation samples are to be provided. Samples will be collected as directed by the well-site geologist.

Logging Program

Gamma Ray - Neutron

Total Depth to Surface

Coupensated Formation

Density - Caliper Total Depth to Surface $3500 \mathrm{ft}+/-$

Laterolog or Equivalent Total Depth to Surface $3500 \mathrm{ft}+/-$

\section{Coring Program}

A maximum of $100 \mathrm{ft}$ of diamond cores will be cut at intervals selected by the well-site geologist.

\section{Formation Water Sampling}

Formation water samples will be obtained by using air as the circulating medium. After the logging program has been completed, the drillpipe will be run into the hole and the hole will be circulated with air until the total depth has been reached. The hole will be circulated with air until the engineer is satisfied that representative formation water samples have been obtained. At least twelve one-gallon plastic containers will be filled with representative formation water samples.

\section{Acldizing of Disposal Formation}

After the formation water samples have been recovered, Nuclear Fuel Services, Inc. may desire that contractor acidize the open hole section of the well before starting the injection testing. In this event, the well will be acidized with 15,000 gallons of 25 percent HCl with corrosion inhibitors. The spent acid will be blown from the hole, using air compressors.

\section{Casing Head}

A steel plate w1ll be welded over the $133 / 8-1 n$. and $95 / 8-1 n$. casing and around the 7-in. casing. A 7-in. x 3-1n. swage will be installed. A 3-in. 300 W. P. Halliburton Lo-Torque valve is to be installed.

\section{P1lot Water Injection Test}

It is the intention of this specification to have the contractor provide sultable pumps, filters, plping manifold, pressure-recording instruments with pulsation dampeners, indicating gauges, dead weight tester, blocide and corrosion inhlbitors, fuel for pumps, and manpower for a complete operational test. The contractor will also provide differentlal temperature surveys. For the purpose of determining the entry points of injected waters, a differentlal temperature survey logging instrument will be run into the hole prior to the start of the injection tests, and differential temperature curves will be obtained following the 50, 75, 100, and $300 \mathrm{gpm}$ injection tests. 
The purpose of the pilot wat. 'njection pump test is to determine a stabilized injection pressure at the head for constant (sustained)
water injection. Injection testing wiıl be performed using at least four different rates viz: $50 \mathrm{gpm}, 75 \mathrm{gpm}, 100 \mathrm{gpm}$, and $300 \mathrm{gpm}$. All injection tests will be maintained at a specific rate until the pressure has stabilized for three hours. After each injection test, the wellhead pressure decline will be recorded during a monitored recovery period. Monitoring instruments will be a pressure recorder with chart, pressure gauges, and a dead weight tester.

A continuous pump test will be run at the volume rate most significant to the projected disposal volumes as determined by the engineer. This will be run for a minimum of forty-eight hours continuously. The operator will record on forms provided by the engineer all pump data hourly and the total gallons injected daily. Twenty-four hour pressure-recording charts will be required for each day the well is under pressure.

The filters will be capable of 125 psig working pressures with adequate pipe manifolds capable of discharge rates of $300 \mathrm{gpm}$. Filter media will be \#l Anthrafilt of 0.6 to $0.8 \mathrm{~mm}$ angular size of approved quality. Filter media depth will not be less than $2 \mathrm{ft}$.

To eliminate all bacteria from the water supply, a quaternary ammonia-type blocide compound will be fed into the filtered water injected into the well. Adoquat, Tect-Treet, or an equivalent type biocide containing corrosion inhibitors is required. Concentrations will be a minimum of 10-15 ppm for each injection rate and $35 \mathrm{ppm}$ during a brief final flush period to ensure the elimination of aerobic and anaerobic bacteria from the wellbore.

Specifications for the proposed disposal well at the NFS Plant were filed with the USAEC Division of Materials Licensing in 1969 (DOCKFT 50201-28). Preliminary discussions (apparently not documented) Involved the AEC Division of Materials Licensing, the U.S. Geological Survey, New York State authorities, the Nuclear Fuel Services Co,, and consultants. One issue that was debated extensively was the question of whether a disposal well would be surrounded by a ring of monitor wells. The proposal for a waste disposal well at the site of the West Valley Plant was not actively pursued after the initial phases discussed above.

\section{Idaho Chemical Processing Plant}

\section{General}

The only well now accepting wastes from a fuel reprocessing plant In the U.S. is located at the Idaho Chenical Reprocessing Plant (ICPP). The ICPP well was not licensed by the former USAEC nor by the present IISNRC, in aciordance with the convention that facilities owned by the AEC or by prime contrgctors to the AEC were not lirensed. This operation differs in several ways irom the concept, generally being, considered in this study, for disposal of wastes from a commerclal reprocess Ing plant. The Idaho well is not a "deep" well; it is only $590 \mathrm{ft}$ deep, In contrast to the roughly 1000 to $10,000-\mathrm{ft}$ depths used in Industrial waste wells and concelved here for fuel-reprocessing wells. The Idaho well discharges to a fresh-water aquifer (the Snake River Plain Aquifer) which is not hydrologically confined; there are no aquitards above the waste-receiving aquifer. Subsurface fluid moves in this aquifer at 
the relatively high rate of up to $20 \mathrm{ft}$ per day (Robertson 1974), In contrast to the rates of a few tenths of a foot per year to a few feet per year estinated for deeper, saline aquifers (Section II1.D). This aquifer also differs from the sandstones of deep sedimentary basins because of its anisotropy and heterogene1ty (Clebsch 1967). Also, theeconcentrations of all radiouctire constituents, except ${ }^{90} \mathrm{Sr}$, in wastes discharged to the Idaho well are below the maximum permissible concentrations in drinking water, in contrast to the estimated composition of commercial LLAW (Table 3). The major nonradioactive constituents of the Idaho wastes have been sodium and chloride (Robertson 1974), whereas in commercial LLAW the majur nonradioactive constituents are expected to be sodium and nitrate (II.B.F).

\section{Site Hydrology and Geology}

The Idaho Chemical Processing Plant (ICPP) is located at the National Reactor Testing Station (NRTS), * which covers 894 square miles of land in southeastern Idaho. The NRTS is located near the central part of the eastern Snake River Plain which is a structural basin about $200 \mathrm{miles}$ long, 50 to 70 miles wide, and with an area of about 12,000 square miles. It extends from the northeastern corner of Idaho, near Yellowstone Park, southwest toward the Hagerman-Twin Falls area. The eastern Snake River Plain consists of a thick sequence of basalt lava flows and sediments, perhaps in excess of $5000 \mathrm{ft}$ thick. The eastern Snake River Plain is underlain by a vast system of continuous groundwater generally contalned within the basalts and interlayered sediments of the Snake River Group. This system has been defined as the Snake River Plain Aquifer. The geology of the Snake Rlver Plain is poorly known because of the lack of commercial incentive to explore it (Robertson 1974). Figure 35 shows a geologic cross section through the area of the ICPP.

Average flow rates in the aquifur are difficult to assess. Tracer studies at the NRTS Indicate natural flow rates in the range of 5 to 20 feet per day with an average near 10 feet per day. However, these local measurements are not necessarily representative of velocitles throughout the aquifer. Indirect estimates of general flow rates were made by assuming certain properties of the aquifer. Studies at the NRTS indicate the effective porosity of the aquifer is in the range of 5 to 10 percent. Actual velocitles, are expected to vary greatly from place to place in the aquifer because of its heterogeneity, but the average velocity is on the order of 5 to 10 feet per day. Using a different approach, $f$. Ow rates of 10 to 20 feet per day were calculated using transmissivities of $5 \times 10^{6}$ to $10 \times 10^{6} \mathrm{gpd} / \mathrm{ft}$, an assumed thickness of 2000 $f t$, and an average hydraulic gradient of 10 feet per mile.

Groundwater in the Snake River Plain aquifer beneath the NRTS contains low levels of dissolved solids and is of good quality for most purposes.

The part of the Snake River Plain aquifer beneath the NRTS is typical of the aquifer in general. Depth of the reglonal water table (Snake River Plain Aquifer) at the NRTS varies from about 200 feet in the northeast corner to 900 feet in the southeast corner. Depth to water in the ICPP area 1s about 450 feet. The average hydraulle gradient is about 5 feet per mile to the southwest. The flow rate beneith the NRTS 18 about $2000 \mathrm{cfs}$. Aquifer pumping tests

\footnotetext{
Recently renamed Idaho National Engineering Laboratory
} 


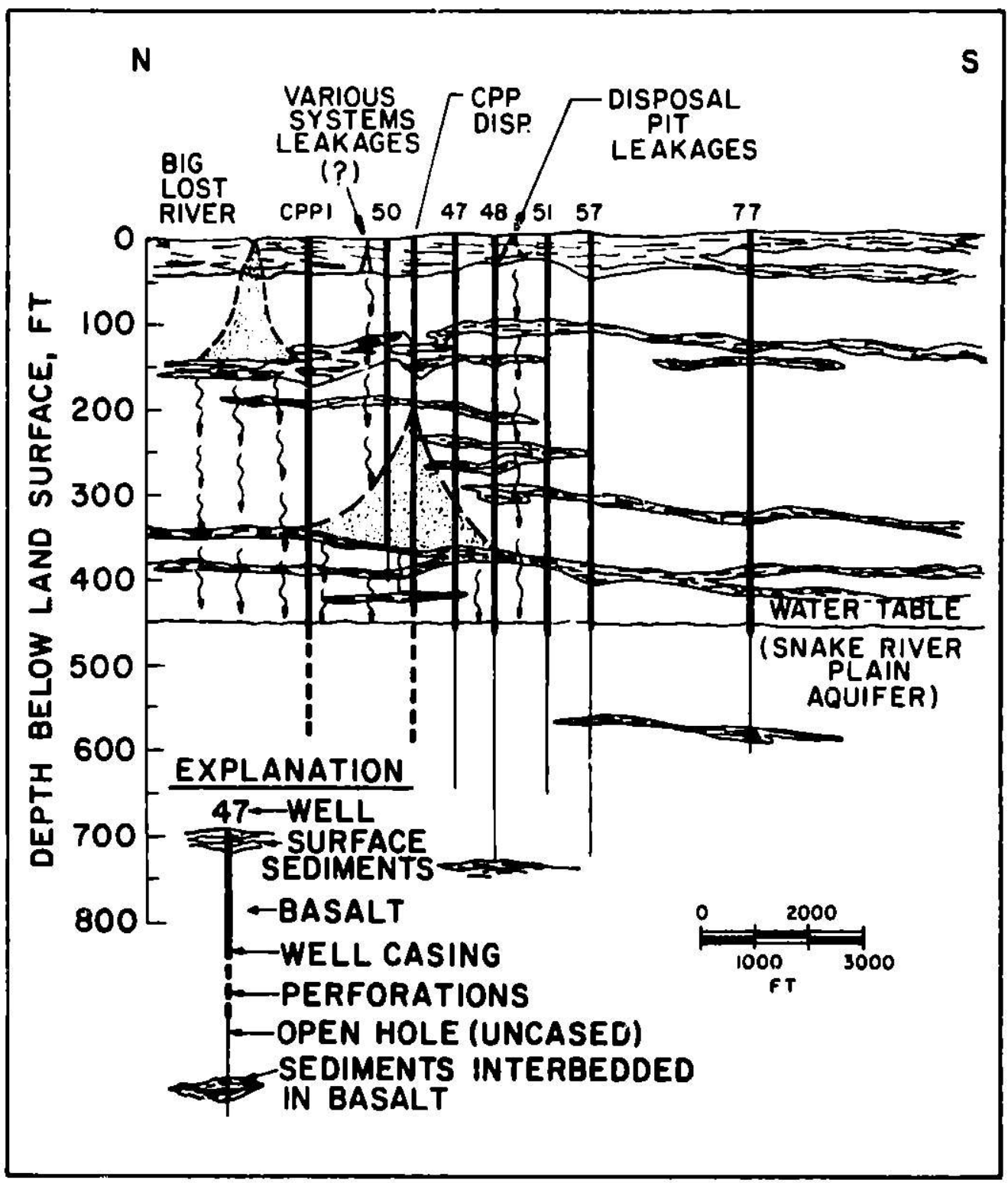

F1g. 35. Geologic Cross Section Through the ICPP Area Showing Generalized Stratigraphy, Perched Water, Wells, and Regional Water Table (Robertson 1974).

performed on 20 different NRTS production and test wells indicate transmissivities ranging from $3 \times 10^{4}$ to $1.8 \times 10^{7} \mathrm{gpd} / \mathrm{ft}$. An average transmissivity for the NRTS might be $2 \times 10^{6}$ to $3 \times 10^{6} \mathrm{gpd} / \mathrm{ft}$. Storage coefficients range from 0.01 to 0.06 (Robertson 1974).

\section{Wastewater}

Nearly all radioactive wastes discharged down the ICPP well are fission and activation products originating from spent fuel elements processed in the plant. Additional but minor sources are the sink drains from the laboratories, where varlous radiolsotopes are used. 
All high-level radioactive liquid wastes are first concentrated by evaporation, then stored for an interim period, and then solidified by calcination. The bulk of the low-level activity that is discharged down the well is evaporator condensate. Before it is discharged to the well, the effluent passes through an ion exchange system to remove most of the cationic radioisotopes. Thus, the low-level radioactive liquid wastes have been purified by a single-stage distillation and ion exchange treatment before discharge. Since tritlated water behaves like normal water, the distillation process does nothing to reduce the tritium concentration. The average characteristics of wastes (in terms of volume and radioactivity) discharged to the well for the years 1953-1970 include a volume of $300 \times 10^{6} \mathrm{gal} / \mathrm{yr}$ and a cencentration of tritium (the most predominant radfoactivity) of about $\$ 26 \mathrm{pCi} / \mathrm{ml}$. The latter is much below the Radiation Concentration Guideline of $3000 \mathrm{pCi} / \mathrm{ml}$ (CFR). Average concentrations of other radiolsotopes are listed in Table 25 . The only radioisotope in excess of public drinking limits is ${ }^{90} \mathrm{Sr}$.

The principal nonradioactive constituents of the waste discharged to the ICPP well are $\mathrm{NaCl}, \mathrm{H}_{2} \mathrm{SO}_{4}, \mathrm{NaOH}, \mathrm{Na}_{2} \mathrm{SO}_{3}, \mathrm{Na}_{3} \mathrm{PO}_{4}$, and $\mathrm{HCl}$. A large quantity of the ICPP process water is softened by conventional ion-exchange softeners, resulting in the discharge of large amounts of $\mathrm{NaCl}$. The waste sulfuric acid and sodium hydroxide result principally from the regeneration of cationic and anionic lon-exchangers used to produce demineralized water for use at the plant. The concentration of total dissolved solids, although uncertain, seems to be near $600 \mathrm{mg} / 1$.

\section{Well Facilities}

The well facilfties at ICPP are rather simple. Wast is initially collected in a concrete-lined pit, from which it is pumped through a 12-in. dia pipe for about 150 yards to the wellhead. No pressure is applied in the injection of the waste; it is a gravity-flow operation. The weil is a carbon steel pipe which is perforated from a depth of about $350 \mathrm{ft}$ to the bottom at about $590 \mathrm{ft}$ (Lohse).

In 1970 it was discovered that the well had collapsed and was plugged at a depth of $226 \mathrm{ft}$ and that all the wastewater was being injected into the unsaturated zone above that level. The original well was $598 \mathrm{ft}$ with a natural water level at about $455 \mathrm{ft}$. The well was orlginally $24 \mathrm{ln}$. in dia, cased with 16-in. steel casing, and gravel packed. The salty, aerated wastewater apparently corroded the casing until it collapsed, allowing the gravel pack and intruding sediments to fill the well to the $226 \mathrm{ft}$ depth. Caliper logs and the first attempts at cleaning the well indicated that only fragmentary corroded pieces were left of the original 16-1n. casing. The last previous depth measurements made in 1966 showed that the well was still intact. It was therefore estimated that most of the collapse took place in 1967 or early 1968. The well was re-drilled and re-lined in 1970 and 1971 to 1 ts original depth (Robertson 1974).

\section{Monitoring}

The wastewater is monitored befure disposal for concentrations of radioactive 1sotopes. It is intended that wastewater in excess of guideline concentrations will be recycied through the plant (Lohse). Also, extensive monitoring of water in the aquifer is practiced. 
Table 25. Maximum Permissible Concentrations of Radioisotopes in Drinking Water Compared with Average Concentrations in ICPP Disposal Well Effluent ${ }^{a}$

\begin{tabular}{|c|c|c|}
\hline Isotope & $\begin{array}{c}\text { Radiation } \\
\text { Concentration Guide } \\
(\mathrm{pC} i / \mathrm{m} 1)\end{array}$ & $\begin{array}{l}\text { Average long-term } \\
\text { concentration in } \\
\text { ICPP effluent } \\
(\mathrm{pCi} / \mathrm{ml})\end{array}$ \\
\hline Cerium-144 & 10 & 4.5 \\
\hline Ces1um-137 & 20 & 2.4 \\
\hline Hydrogen-3 (tritium) & 3000 & 526 \\
\hline Ruthen ium-106 & 10 & 1.1 \\
\hline Strontium- 89 & 3 & 0.39 \\
\hline Strontium-90 & $0.3^{c}$ & 2.4 \\
\hline Zirconium-95 & 60 & 3.0 \\
\hline $\begin{array}{l}{ }^{a} \text { From Robertson } 1974 . \\
b_{\text {For unrestricted are }}\end{array}$ & & \\
\hline
\end{tabular}




\section{Regulations}

The main regulatory requirements governin's operation of the well involve meeting the guideline concentrations for radioactive isotopes. Well operations must meet the requirements of both the State of Idaho (which are said to be equivalent to 10CFR20) and the ERDA manua1, Chapter 0524 (Lohse).

Data taken in 1966 indicate that ${ }^{90} \mathrm{Sr}$ concentrations in the aquifer from ICPP have ranged up to about $0.2 \mathrm{pCi} / \mathrm{ml}$. The maximum concentrations observed in 1970 were about $0.06 \mathrm{pCi} / \mathrm{ml}$. The guide concentration for ${ }^{90} \mathrm{Sr}$ in drinking water for a special area such as the NRTS is $0.3 \mathrm{pCi} / \mathrm{ml}$ (AEC regulations). For public supply, the drinking water supply wells which contain detectable ${ }^{90} \mathrm{Sr}$ are the $\mathrm{CPP}-1$ and -2 wells. Water from the $\mathrm{CPP}-1$ and $\mathrm{CPP}-2$ wells has contained as much as 0.04 and $0.03 \mathrm{pCi} / \mathrm{ml}{ }^{90} \mathrm{Sr}$, respectively. Both $\mathrm{AEC}$ and PHS limits are based on Federal Radiation Council recommendations and the difference is based partially on greater monitoring and control and lower per capita intake rate for a special supply versus a public supply.

\section{Distribution of Wastes in the Aquifer}

The principal ICPP waste products include NaCl, tritium, ${ }^{90} \mathrm{Sr}, 1{ }^{37} \mathrm{Cs}$, and heat. Analysis of the observed behavior of these products in the aquifer over the period 1953-1970 indicates that dispersion is a very significant mechanism in spreading and diluting the waste plume. This extraordinary dispersion process may be due largely to differential verticul and anisotropy in the aquifer, although channel branching and turbulent mixing in the relatively fast-flowing groundwater may be involved. Basalt has relatively poor ionexchange capacity (compared to fine sediments); nevertheless, exchange or sorption appears to have a prominent influence on cationic waste products in the aquifer (namely ${ }^{137} \mathrm{Cs},{ }^{90} \mathrm{Sr}$, and sodium). Cesium-137 concentration in the aquifer water has been lowered by sorption below detection limits.

Tritium and $\mathrm{NaCl}$, the most widespread wastes in groundwater at the NRTS, have been carried down-gradient in detectable quantities about 4.5 miles and have contaminated an area of at least 12 to 15 square miles of the aquifer. Concentrations of these wastes are very sma1i, however, and no groundwater contemination has been detected close to the houndary of the NRTS.

Materials balance analyses and other data indicate that most of the wastes discharged at the NRTS renain in the upper $250 \mathrm{ft}$ of the Snake River Plain aquifer, as they migrate down-gradient.

Data avaliable at this time indicate that liquid waste discharged to groundwater in the Snake River Plain aquifer beneath the NRTS at tenuates rapidly due to dispersion in the flowing groundwater, sorption of some cationic wastes, and decay of all radionuclides (Robertson 1974).

\section{E. Allied-Gulf Nuclear Services, Barnwell Nuclear Fuel Plant, Barnwe1l, South Carolina}

The Barnwell Nuclear Fuel Plant lies on the Atlantic coastal plain and is underlain by about $1000 \mathrm{ft}$ of unconsolidated to semi-consolidated gravels, sandstones, siltstones, and clays of Quatecuary to Cretaceous age. These sediments overlie sandstones and basalts of Triassic age and Precambrian age 
metamorphic rocks. Because the entire sedimentary sequence at Barnwell is fresh-water bearing, there is no potential for subsurface injection as conceived of in this report. Burial of high-level wastes in mined openings in Triassic or Precambrian rocks has been extensively considered at the nearby Savannah River Plant, as is discussed in Appendix A.

F. General Electric Fuel Reprocessing Plant, Morris, I1linois

\section{General Discussion}

The General Electric $C_{0}$. and its consultants apparently considered subsurface injection only briefly as a possible means of disposing of lowlevel aqueous wastes generated at its Midwest Fuel Reprocessing Plant located at Morris, Illinois (NEDO-14504, NEDO-14504-2). These considerations led to the conclusions that a reduction factor of 90 to 99 percent for tritium release was expected; that the method was technically feasible; that the local hydrology was favorable, but subject to detalled safety analysis, regulatory review and public acceptance; and that a ccst range of $\$ 0.4$ million to $\$ 0.5$ million was expected. The cost types and time periods considered in this cost estimate were not specified.

\section{General Geology}

The general geologic characteristics of the Morris area for waste injection will be briefly considered, using published and unpublished information of the type described in Section III. The Morris site is in Grundy County in northeastern Illinois. About $4000 \mathrm{ft}$ of sedimentaiy rocks underlie the site. The general stratigraphic sequence is given in Fig. 5. As discussed in Section III, the Mt. Simon formation is the most desirable possible injection interval in this area. At the site, it is about $2000 \mathrm{ft}$ thick. Combined with adjacent overlying sandstones in the Eau Claire, the total thickness of the basal sandstone body is over $2500 \mathrm{ft}$. Data from deep wells in the area indicate very favorable porosity and permeability (Fig. 16). The upper $400 \mathrm{ft}$ of shale and siltstone in the Eau Claire formation is present to confine the basal sandstone (Fig. 5 and 7).

Aquifers immediately above the Eau Claire probably contain fresh tu brackish water at Morris. Water in the basal Eau Claire and upper Mt. Simon will not be fresh, but it may contain less than 10,000 ppm of dissolved solids, which the State of Illinois has used as a minimum limit for water in aquifers permitted for disposal (FIg. 14). The lower Mt. Simon will contain very saline water.

No commercial ofl or gas has been found in the Mt. Simon or Eau Claire formations in Illinols, but these formations are extensively used for gas storage in northern Illinots.

A falrly extensive fault, the Sandwich fault, lies northeast of the Morris site. The regional significance of this fault has not been studied in relation to subsurface waste disposal.

Thus it is concluded at this time that the possibility of deep-well infection of liquid waste at the Morris site is generally favored by the nature of the underground formations, but would depend on whether the concentration 
of dissulved solids in the furmation of interest is below the permissible limit and also on the significance of the Sandwich fault.

\section{$\mathrm{X}$. CONCLUSIONS}

\section{A. Technology}

The teclinology of deep-well injection of wastes was reviewed, including the requirements imposed by the volume and the chemical, physical, and biological nature of the waste, as well as design, operation, and monitoring considerations. It is concluded from this review that the method should be as applicable to LLAW as it has been applicable with apparent success to wastes of the chemical industry. The need for technical innovation in application to LLAW seem to be small. In fact, the LLAW promises to be less noxious than some of the chemical industry wastes discharged into deep wells. Because of the very low concentrations of dissolved solids in LLAW, the technique can probably be applied with less pretreatment than i.s required for many wastes presently being injected by the chemical industry. The relative chemical purity of the waste, except for nitrates, may result in the requirement of an Ionic additive to prevent the dispersion of clays that could result in plugging of formation pores. Perhaps the main requirement for revision of normal technology may result from the accumulation (plate-out) of radioisotopes (although present in trace concentrations) in piping and equipment, leading to the necessity for developing equipment handling procedures different from those normally used in the operation of oil-industry or waste-disposal wells.

\section{B. Economics}

The total capital and operating costs for deep-wall injection of LLAW were estimated to be of the order of magnitude of $10^{-4} \mathrm{mill} / \mathrm{kWh}$. This number does not include the contribution of several cost items which cannot be accurately estimated at this time, such as costs for prospecting, decommissioning, and survelllance (both before and after decomnissioning). The limfted accuracy of the cost estimate should be noted, however. The difficulty of arriving at an accurate cost is related to the change in the value of the dollar, the rapidly changing costs of goods and services, the variation in cost with the depth and geologic characteristics of sites, and changing equipment. To be economically feasible, any tritlum-control method should have a cost that is only a small fraction of the total cost allotted to the management of wastes from the nuclear fuel cycle; most of the cost is assumed to be committed to the control of the greater hazards of high-level wastes and transuranfum wastes. A recent estimate of the total cost to be allotted to waste management is $0.05 \mathrm{mill} / \mathrm{kWh}$ (WASH11.74-74).

The cost quoted above for successful practice of deep-well injection of LLAW can be compared with the cost/benefit ratio for exposure incurred from blospheric dispersal of the tritium. The ratio for dispersal can be calculated from the annual whole-body dose of 3900 man-rem projected by the EPA for exposure to tritium discharged at a $5 \mathrm{MTU} / \mathrm{yr}$ reprocessing plant and from the interim assignment by the NRC of a value of $\$ 1000$ per whole-body man-rem. On these bases, the cost of exposure to conventional methods of tritium disposal is about $1 \times 10^{-2} \mathrm{mill} / \mathrm{kWh}$. 
The unit cost for deep-well injection could increase greatly, however, if maloperations resulted in public exposure to tritium. Accordingly, the effect of an upper limit accident was estimated in terms of a unit cost. Escape of 100 percent of the low-level aqueous wastes injected from a $5 \mathrm{MTU} /$ day reprocessing plant into public water supply could result in a maximum population dose, based on continuous consumption, of $3 \times 10^{5}$ man-rem/yr, corresponding to a unit cost of $0.8 \mathrm{mill} / \mathrm{kWh}$.

\section{Envi ronmental Impact}

In every case, the environmental effects induced by the very nature of the thethod are modification of the groundwater system and introduction into the subsurface of flutds with a chemical composition different from that of the natural fluids. These effects do not necessarily result in an impact on the biospheric segment of the environment and, in fact, are normally designed to have no effect on the biosphere. The most important environmental impacts that could occur in individual cases as a iesult of unplanned, adverse incidents are degradation of high-quality groundwater, contamination of resources, and the stimulation of earthquakes.

The impact of greatest concern is the contamination of potable water. Concepts of the worst case of contamination of potable water indicate that the normal low-level waste from a $5 \mathrm{MTU} /$ day reprocessing plant has the capacity to expose almost 7000 persons to water contaminated to the Public Health Service nitrate limit for drinking water. Also, a worse-case maloperation in which 100 percent of the low-level aqueous waste from a $5 \mathrm{MTU} / \mathrm{day}$ reprocessing $\mathrm{plant}$ efcapes into the public water supply and is consumed continuously at maximum permissible concentration, has the capacity for a maximum population dose of $3 \times 10^{5} \mathrm{man}-\mathrm{rem} / \mathrm{yr}$.

If the disposal can be carried out as intended, however (i.e., without. adverse incidents), exposure of the biospheric segment of the environment to the constituents of LLAW are expected to be nil compared with the estimated annual dose oi 3900 man-rem/yr incurred from dispersal of the LLAW from a 5 MTU/day reprocessing plant to the atmosphere or to surface streams.

\section{Siting}

The suitability of a site for deep-well injection of wastewater can be assessed by consideration of a number of types of information: Consultation of recorded information on stratigraphy, structure, and lithology (composition and texture) of rock strata. The properties of the natural subsurface water in the area should be considered, e.g., chemical composition, viscosity, pressure, and compressibility. Data on the mechanical properties of the rock units, such as porosity, permeability, compressibility, tomperature, and state of stress should be consldered. The hydrodynamics of the subsurface region, $i$.e., the fluw of natural water and 1 ts relevance to waste containment can be deduced. The resources of the region and the possible effects of waste injection on their value should be taken into account.

The acquisition of data describing the subsurface of a region may be obtained prior to drilling from records of state geologic surveys, ofl and gas agencles, water-resources agencles, and private companies. Retrieval by automatic data processing techniques of geologic and subsurface engineering 
information that would be useful in site evaluation has not yet bocone generally available.

Data on a particular well can be obtained as drilling proceeds from analyses of rock samples and formation fluids, from a large number of borehole geophysical logging techniques, and from tests that involve pumping fluid into or out of the well at various stages of completion.

Predictions of the response of the aquifer to injection include effects on subsurface flow of natural fluids in the region of influence, effects of pressure, the rate and direction of flow of the waste, the possibility of hydraulic fracturing of the overburden, and the stimulation of earthquakes.

The areas of the U.S. most likely to have gcologic properties suitable for deep-well injection are the sedimentary basins. The sum of the areas of these basins is great, indicating an abundance of areas offering suitable geologic properties. Recorded descriptions of the sedimentary basins of the eastern and middle sections of the U.S. are available in detail, but some of the basins of the far western section of the country are less well explored and described. Recorded information on U.S. basins would serve only for preliminary assessments of the suitability of a region, and would have to be followed by more detailed analysis of a particular site of interest.

Present attitudes toward transport of liquid radioactive wastes and economic concerns suggest that the site of a well for disposal of LLAW would best be located at the fuel reprocessing plant which is the source of LLAW.

\section{E. Legal and Regulatory Constraints}

Legal and regulatory constraints may be the most formidable barrier to the application of deep-well injection to the disposal of LLAW. This conclusion is made not necessarily in anticipation of prohibition, but in anticipation of the time, effort, and expense that may be needed to satisfy the requirements of review and regulation.

The laws and regulations of a state, if adequate, would be of primaxy consideration. At present, state laws that apply to deep-well injection vary from those addressed to pollution control in general to those which are detailed and apply specifically to waste wells. A few states prohibit waste wells either by law or by regulation. In several states, laws and regulations applying to waste wells may be expected to develop further in the near future. Recent federal guidelines, expressed In EPA Administrator's Decision Statement \#5, PL 92 500, and PL 93-523 may be expected to influence greatly the course of future developments in state laws and regulations. Waste wells within states without adequate laws and regulations for waste wells would be regulated by a federal agency. In any case, for disposal of LLAW produced by a commercial reprocessing plant, it is expected that, because of the origin of the waste, the Federal Regulating agency would be NRC (and EPA under safe drinking water act) and that a state with adequate regulational structure would share the Is gulatory responsibilities.with NRC.

In addition to the need to operate within state and federal legal structures, legal action based on civil law may be expected in cases where waste infection results in claims of civil grievance. 
A waste well installed at a fuel reprocessing plant in conjunction with the construction of the plant would be described in the Environmental Impact Statement of the plant and examined in the Environmental Impact Review of the plant and its various facilities. It is expected that although NRC and a state government agency would eventually regulate any operations of such a waste well, the review would include representatives of several agencles, including the state government involved, USGS, and EPA. On the other hand, the application for a waste we: 1 to be installed at an already-operating commercial fuelreprocessing plant would probably involvc filing an application that would be reviewed by representatives of the agencles described above. This review would be expected to result in a recommendation to proceed, to desist, or to initiate a more extensive review. The latter could include preparation of a draft environmental report by the Applicant. That review would serve as a basis for a draft environmental statement prepared by NRC and circulated to other agencies for review, a public hearing, and finally the preparation of an environmental impact statement by NRC. 
APPENDIX A.

Mechods other than Deep-Well Injection for Geological Emplacement of Fuel-Reprocessing Wastes

In order to further delimit and clarify the area of interest, there follows in Sections 1,?, 3, and 4 of this appendix, descriptions of geologic wasteemplacement concepts that should not be confused with the technique of main interes! in this study, i.e., deep-well injection or emplacement of 1iquids into deep-lying permeable strata.

\section{Storage of liquid HAW in Savannah River Bedrock}

One geologic emplacement technique to be distinguished from deep-well injection is storage of radioaclive waste liquids in tunnels excavated from bedrock. A largo volume (about $80,000,000$ gal) of high level liquid wastes, accumulated at the sivantah $R$ iver plant as a result of production of plutonium fur weapons, has been aged in tanks, but will eventually be disposed of by some "ult imate" method. One it the methods proposed as early as 1951 (NASNRC: 1972) is excivation to form a network of tunnels in the bedrock below the plant site, and emplacement of the Liquids in the tumels. Figure $A-1$ is il dlagram of the proposed storige factlity.

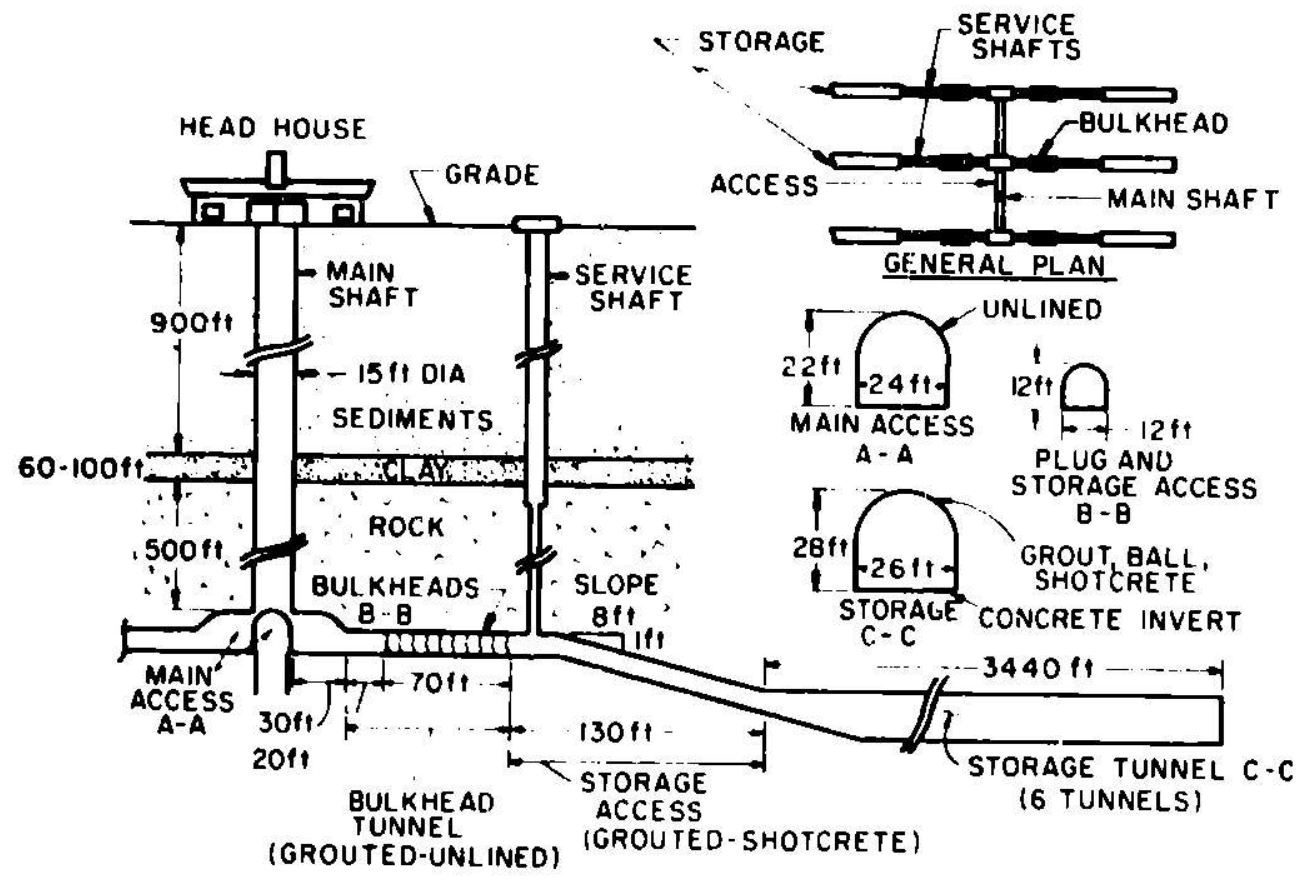

Fig. A-1. Cross section of Proposed Bedrock Waste Storage Facllity at Savannali RIver Plant (NAS-NRC 1972).

2. Hydraulic Fratcurlng

Another geologic emplacement technique differing from deep-well inject fon Is termed hydraulic fracturing (1) daguni 19681, Sun). Wistes are nixed with cement as a grout which is injected into a thick, nearly impervious shale formation. Hydraulf fracturing during injection serves to provide openings in the shale. The grout is allowed to solidify under pressure, sheets are 
expected to furm which will become an integral part of the shale, thereby imnobilizing the wastes in the impervious mediun. Disposil of radioactive wastes by this technique has been done only at the Oak Ridge National Laboratory. Some lests of the technique were also made in New York state near West Valley; only water was used in five cases and a grout in one case (Delaguna 1972). Figure A-2 illustrates the cuncept of waste disposal by hydraulic fracturing.

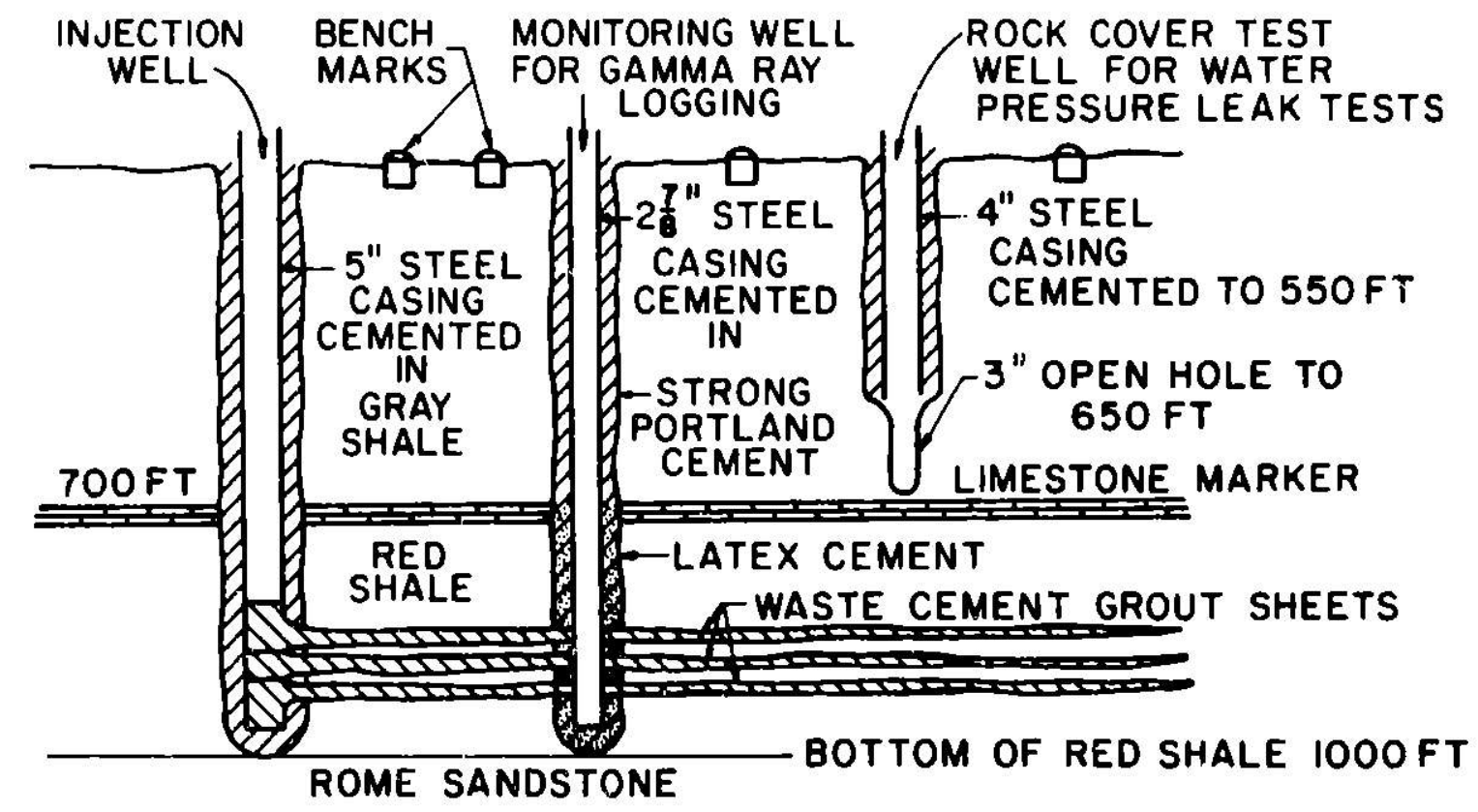

Fig. A-2. Diagram of the Concept of Waste Disposal by Hydraulic Fracturing as Tested at the ORNL Site (Delaguna 1968B)

\section{Liquid Disposal Through Cribs}

The waste disposal systems termed cribs were probahly first used at the Hanford reservation. At Hanford, the method consists essentially of letting fluid radioactive wastes percolate through soil columns of perhaps $350 \mathrm{ft}$ depth to the groundwater table. Originally, a crib was little more than a shillow hole slightly below surface level. Later, cribs were more elaborate (Fig. A-3a), with the upper layers consisting of rock and gravel of various sizes (NAS-NRC-1957). By ion-exchange and absorption, the soll removed lonic species to extents resulting in a chromatographic effect as suggested by Fig. A-3b. Some liquid low-level wastes from the ldaho Chemical Processing Plant were also discharged to shallow seepage pits fur several years (Robertson 1973).

\section{Incorporation of Nuclear Waste in Deep Molten Silicate Rock}

A fourth method to be distinguished from deep-well infection is the concept of incorporating waste into molten silicate rock at great depths below the surface of a reprocessing plant (Cohen 1971). The method proposes the emplacement of wastes in deep, underground rubble-fllled chimncys initially created by a nuclear explosion, one of the Plowshare applialions. liquid 


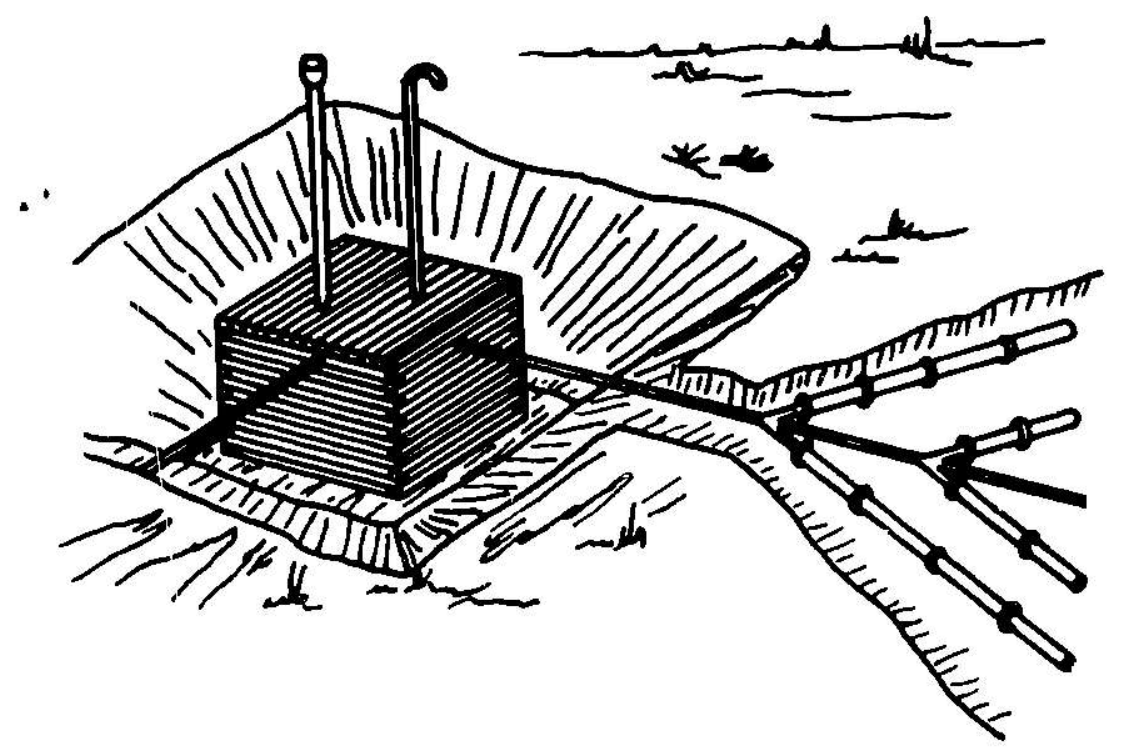

Fig. A-3a. Crib-and-Tile Field Before Backfill (Straub).

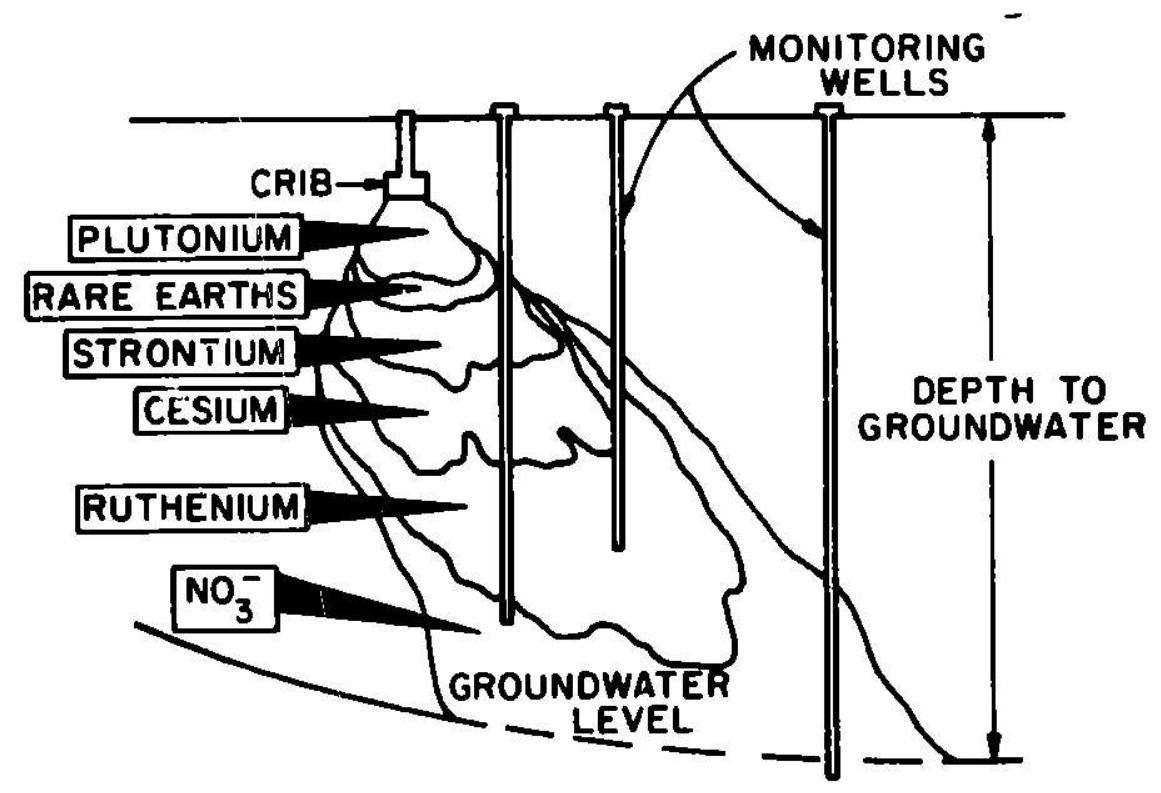

Fig. A-3b. Movement of Specific Ions froln Cribs (Straub).

wastes from the fuel-reprocessing plant above the chimney would be injected into the chimney. During the lifetime of the venture, steam from selfboiling of the wastes would be condensed and recirculated to cool the chimney, preventing the rock from melting. When the capacity of the chimney is reached or the venture is terminated, water cooling would be stopped. In the absence of cooling, the rock in the rubble chimney would melt, and the radioactive waste would dissolve in the molten roc!.. After a number of years, the radioactivity would be expected to diminish, resulting in eventual cooling and solidification of the rock. The proposed resul.t is permanent incorporation of the waste in an insoluble stlicate rock matrix underground. The process is briefly illustrated in Fig. A-4. 


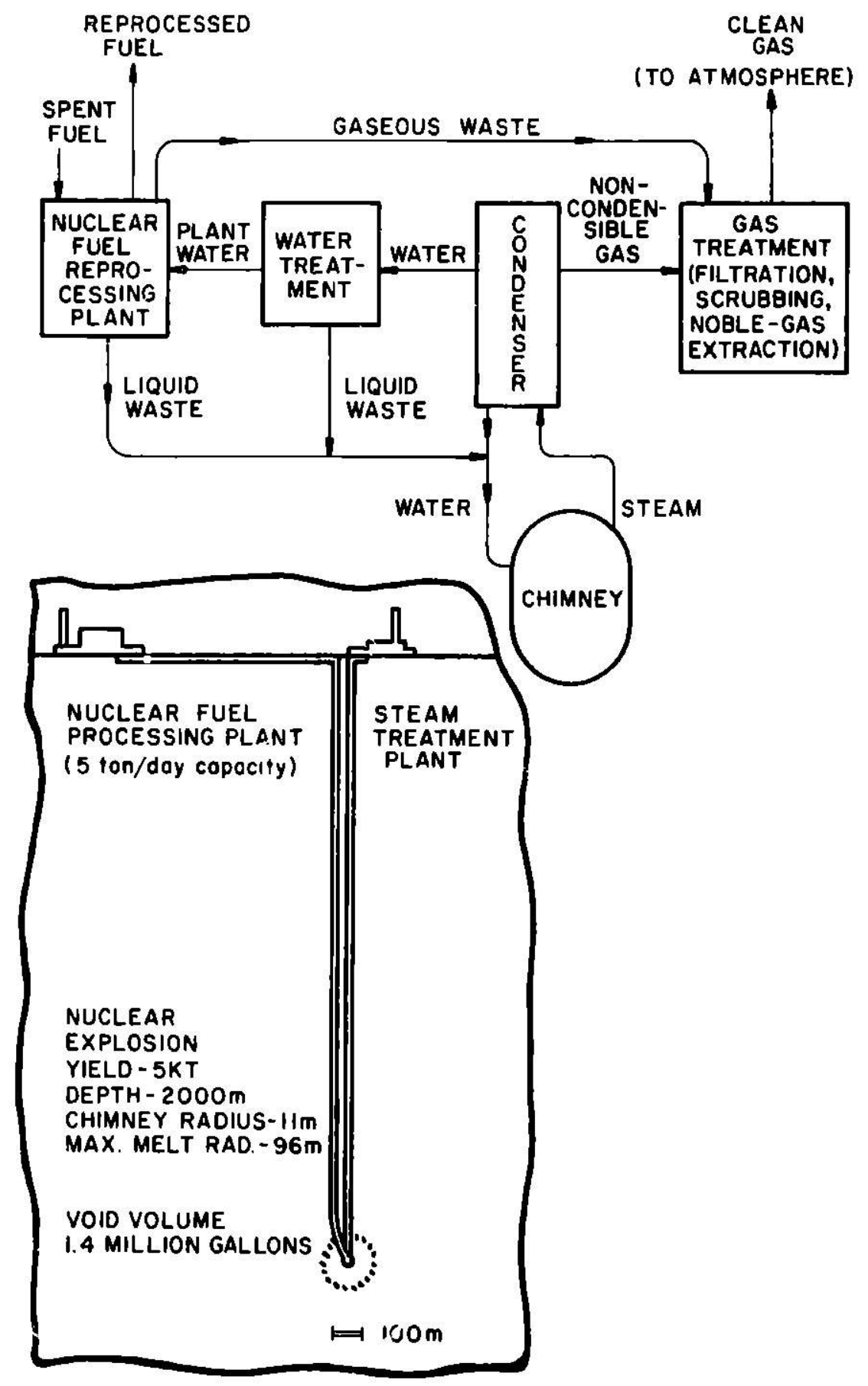

Fig. A-4. Composite Illustration of the Concept of Disposal of Nuclear Waste in Deep Molten Silicate Rock. 
APPENDIX B.

Equivalency of Permeability in Various Units (Dav1s 1966)

$\begin{array}{ll}1 \text { darcy } & =9.87 \times 10^{-9} \mathrm{~cm}^{2}=1.062 \times 10^{-11} \mathrm{ft}^{2} \\ 10^{-10} \mathrm{~cm}^{2} & =1.012 \times 10^{-2} \text { darcys } \\ 0.1 \mathrm{~cm} / \text { day } & =1.15 \times 10^{-6} \mathrm{~cm} / \mathrm{sec} \approx \begin{array}{r}1.18 \times 10^{-11} \mathrm{~cm}^{2} \text { for } \\ \text { water at } 20^{\circ} \mathrm{C}\end{array} \\ 1.0 \mathrm{~cm} / \mathrm{sec} & \approx 1.02 \times 10^{-5} \mathrm{~cm}^{2} \text { for water at } 20^{\circ} \mathrm{C} \\ 1 \text { darcy } & \approx 18.2 \text { meinzer units for water at } 60^{\circ} \mathrm{F} \\ 1 \text { meinzer } & =0.134 \mathrm{ft} / \text { day } \begin{array}{r}4.7 \times 10^{-5} \mathrm{~cm} / \mathrm{sec} \\ \approx 5.5 \times 10^{-2} \text { darcys for } \\ \text { water at } 60^{\circ} \mathrm{F}\end{array}\end{array}$


APPENDIX C

Example of a Comprehensive Set of State Regulations by the Colorado Dept. of Health, Water Pollution C Introl Commission

RULES AND REGULATIONS FOR SUBSURFACE DISPLSAL SYSTEMS*

Section 1. - DECLARATION OF POLICY. - These Rules and Regulations provide the conditions for the location, construction and operation of subsurface disposal systems. After the effective date of the adoption of these Rules and Regulations, no subsurface disposal system shall be constructed or operated in this State contrary to the provisions of these Rules and Regulations.

Section 2. - DEFINITIONS. - As used in these Regulations:

(a) "Act" means the Colorado Water Pollution Control Act of 1966, Chapter 66, Art1cle 28, C.R.S. 1963 (1967 Perm. Cum. Supp.).

(b) "Aquifer" means a permeable formation which contains and transmits ground water or formation water.

(c) "Coefficient of Storage" means the volume of water released from a unit volume of the aquifer when the piezometric surface declines one (1) foot.

(d) "Comnission" means the Colorado Water Pollution Control Commission.

(e) "Construction" when used with respect to a disposal system shall mean any initial creation of a new disposal system, any material modification or alteration of any existing disposal system, and the conversion of any condition or structure not previously used as a disposal system into such a system.

(f) "Disposal aquifer" is any aquifer into which wastes are intended to be disposed of by means of a disposal system.

(g) "Dispose" and "Disposal" mean the deposit, generation, creation, or discharge of any wastes at any level below the land surface.

(h) "Operate" when used with respect to a disposal system means the use or employment of that system to dispose of wastes below the surface of the land.

(1) "Person" means the state, or any agency or institution thereof, any municipality, political subdivision, public or private corporation, individual, partnership, association, or other entity, and includes any officer or governing or managing body of any municipality, political subdivision, or public or private corporation.

(f) "Pollution" means such contamination, or other alteration of the physical, chemical, or biological properties of any waters of the state, including change in temperature, taste, color, turbldity, or odor of the waters, or

\footnotetext{
*Effective Date: July 1, 1970.
} 
such discharge of any liquid, gaseous, solid, radioactlve, or other substance into any waters of the state as will or is likely to create a nulsance or render such waters harmful, detrimental, or injurious to public health, safety, or welfare, or to domestic, commercial, industrial, agricultural, recreational, or other beneficial uses, or to livestock, wild animals, birds, fish or other aquatic life.

(k) "Subsurface" means any level below the surface of the land.

(1) "Subsurface disposal system" means any system or facility, method, excavation, well structure or condition of any kind whatsoever (other than septic tank systems, solid waste disposal sites, sanitary landfills, refuse disposal sites, oil and gas wells, water injection wells employed in ofl and gas well operations, surface ditches or retention pcorls and irrigation and water transportation systems), used, employed or operi. ad so that the same may reasonably be expected, by direct or indirect means, to result in the disposal of wastes underground, including without limitation, the following: Sewage systems, treatment works, wells into which wastes are deposited or injected, installations, structures, wells and excavations to be used in connection with any subsurface explosion, detonation, reaction or process that might tend to discharge, deposit or generate wastes underground, and mines or other excavations initially made for other purposes when they are used for disposal.

(m) "Subsurface water" or "Groundwater" means any waters of the State not visible on the surface of the ground under natural conditions.

(n) "System" means all surface and subsurface equipment, Installations and appurtenances and shall include the formations within the zone of influence of a subsurface disposal system.

(o) "Waste" means any substance, solid, liquid or gaseous, including radioactive particles thereof, which pollute or may tend to pollute any waters of the State.

(p) "Workover" means any remedial procedure which could change the physical or chemical characteristics of the formation, or changes in physical equipment (other than routine maintenance of mechanical equipmen $c$ ), changes in method of injection (asidizing, artificial fracturing), repalring or replacing casings, tubing, packing and plugglng or perforating additional zones.

(q) "Zone of Influence" means the areal extent to which a waste can or will migrate or be dispersed within a stated period of time from a subsurface disposal system, as well as the areal extent of the significant variations of formation fluids caused by such a system.

\section{Section 3. - PREREQUISITES TO CONSTRUCTION AND OPERATION OF SUBSURFACE DISPOSAL SYSTEMS.}

(a) No person shall construct or operate a subsurface disposal system within the State of Colorado unless such person has a currently effective permit for such construction or operation issued by the Commission pursuant to this Section. 
(b) No person shall receive a permit from the Commission for the construction or operation of a subsurface disposal system within the State of Colorado unless the Commission, acting upon the application of a person proposing to construct or operate a subsurface disposal system shall have found and determined beyond a reasonable doubt with respect to the proposed subsurface disposal system, after notice and public hearing, one of the following:

(1) that no waters of the State will be adversely affected thereby; or

(2) that if waters of the State may be adversely affected thereby, it is reasonably certain such waters have then no present or foreseeable beneficial use and there is no reasonable probability such waters, if adversely affected, will mingle with or be tributary to beneficially usable waters of the State; or

(3) that if the waters of the State affected by the proposed system may mi igle with or be tributary to beneficially usable waters, that the proposed system provides for such protective measures or plan of treatment as will adequately preserve with reasonable certainty, the beneficial uses and prevent the pollution of such waters; or

(4) that if any beneficially usable waters of the State may be polluted by the operation of the proposed system, that there is no risk of significant migration of such waters and that the proposed activity is justified by public need.

Any other finding by the Commission shall preclude the corstruction or operation of a subsurface disposal system at the site proposed in the application in response to which the Commission has made its findings.

(c) Every finding by the Commission under the provisions of subparagraph (b) of this Section shall be stated in writing, refer to the application upon which it was based, and shall be final; provided, however, the Comnission will grant a rehearing to an applicant requesting the same if good cause therefore be shown to the Commission and such request is made within 30 days after the date of the entry of the Commisston's findings. When information or data other than that contained in an application is considered by the Commission in making its finding, the applicant or any interested person shall have a right, upon request, to be informed of the nature and source of such information or data. Any person assuming to construct and/or operate a subsurface disposal system, with or without a permit iss ded by the Commission, shall be solely responsible for such system and shal.1 be deemed to have assumed all risks in respect to the construction and operation of such system.

(d) When the Commission shall have, pursuant to applicatis, made one of the findings described in subparagraphs (1) - (4) of subsection (b) of this Section, the Commission shall grant to the applicant a permit to construct, operate, or construct and operate, as the case may be, the subsurface disposal system for which the application has been made, which permit may be subject to any conditions reasonably required by the Commission.

(e) Any person having applied to and received from the Commission a permit under the provistons of this Section and thereafter assuming to construct and/ or operate a subsurface disposal system under that permit shall be subject. 
always to such orders and regulations as the Commission may reasunably require, from time to time, for the prevention, abatement and control of pollution to the waters of the State, including but not limited to one or more of the following:

(1) that no zone or interval, other than the zone or interval represented to the Commission as the disposal interval or aquifer, shall be used as part of the system except after notice and hearing.

(2) that a monitoring system, including prescribed equipment, tests, and installations, shall be provided and operated at the sole risk, cost and expense of the persons interested in the system; provided, however, the Commission may designate some third party to utilize the monitoring system data developed by or for the operation of the system.

(3) that treatment of wastes shall be provided to that degree required by the Commission.

(4) that workover or remedial procedures shall not be performed without prior notification to the Coramission and then only to the extent ordered by the Commission.

(5) that disposal shall be only in such manner as mav be ordered by the Commission in respect to volume, rate, pressure, and similar parameters and shall not exceed that specified or be of a kind different from that presented to the Commission upon the application flled under the provisions of Section 4 of these Rules and Regulations.

(6) that all drilling, completing, and operating procedures for subsurface disposal and monftoring systems or wells shall conform to those practices and procedures previously reviewed by the Commission and that any deviation in procedure or equipment from that specified in the applications presented to the Comnission shall require the concurrence of the Commission before deviation from such procedures may be implemented.

(7) that an adequate back-up facility be provided, including surface equipment, pumps, well-head, transmission lines, holding tanks, retention ponds and treatment facilities, to assure that a system may be safely shut down in the event of component failure and to assure the treatment of effluent to a suitable degree for temporary surface disposal.

(8) that evidence of financial responsibility be submitted to the Commisston and, when the Commission so requires by its order, security, in the form of cash, approved securities, surety bond, or evidence of insurance, be deposited with the Treasurer of the State of Colorado, in such amount and with and under such conditions as the Commission may direct to assure the people of the State of Colorado of the continued compliance with the Commisston's orders and that, upon abandonment, cessation or interruption of the construction or operation of the system, appropriate measures will be taken to prevent present or future pollution of the beneficlally usable waters of the State. Whenever evidence of financial responsibility is required, such evidence shall be furnished annually for as long as the Cominission may require. 
(9) that the Commission shall be furnished with such reports, charts, forms, and other information as 1 t may reasonably require and at such intervaj.s as may be directed by the Commission from time to time.

(10) that notwithstanding any prior finding, order or permit of the Commission, the continued or future construction or operation or use of a disposal system shall, upon order of the Commission, be discontinued after notice and hearing if the Commission determines that continued operation thereof is or may tend to be injurious to the then present or foreseeably beneficially usable waters of the State.

Failure to comply with any condition or order of the Commission in respect to any disposal system, or any action required to be taken in respect thereto shall be cause for the Commission to order the suspension or termination of construction or operation of such system, and the suspension or revocation of any permit issued pursuant to this Section.

Section 4. - APPLICATION FILED WITH COMMISSION. - Any person proposing to construct or operate, or cause to be constructed or operated, a subsurface disposal system within the State of Colorado shall file with the Commission a verified, written application for a permit under Section 3 of these Rules and Regulations. Such application shall contain, unless the requirement is waived as inapplicable by an order of the Commission, the following:

(a) A legal description of the area within a radius of two (2) miles of the proposed system and a legal description of the site upon which the system will be located.

(b) An accurate map of the area within a two (2) miles radius of the proposed system showing the location of the system, property boundaries, surface and mineral ownership of record, the location of all water wells and oil and gas wells and whether the same are operating or have been abandoned and, if appropriate, whether such wells have been plugged; and the location of all mines, test holes and other artificial penetrations or excavations.

(c) A description of the depths and deepest formations penetrated by each of the wells, mines, excavations or penetrations required to be shown on the map required at (b) above.

(d) A description of local topography, industry, agriculture, population densities, culture, wildlife, and fish and other aquatic life within the area of the proposed system with a projection as to the probable effect of the system upon industry, agriculture, population, culture, wildlife, and fish and other aquatic life.

(e) A description of the mineral resources believed to be present in the area of the system and the probable effect of the system upon such mineral resources, together with a map or maps illustrating geologic structures and stratigraphic sections (formations, lithologles and physical characteristics for the local area and a general map lllustrating the reglonal geologic setting of the system). Such exhibits shall be prepared by a qualified expert.

(f) A description of all water resources, both surface and subsurface, within the probable zone of influence of the system, the classification if any, the 
avallable amounts therenf and potent al uses and a map or maps indicating vertical and lateral limits of suriace and subsurface water supplies.

(g) A description of the chemfcal, physical, radiological, and biological properties and characteristics of the wastes to be disposed of through the system, and the treatment proposed for such wastes.

(h) Copies of all plans and speciflcations for the system and its appurterances.

(1) A statement of all sources relied upon for the Information set forth in the application.

(j) If the disposal system is to be an injection well, and if requested by the Commission in the case of any application, the following information may be required:

(1) Potentiometric surface maps of the disposal aquifers and those aquifers immediately above and below the disposal aquifer.

(2) Copies of all drill-stem tests, extrapolations and data used in making the maps required at ( 1 ) above.

(3) Location and nature of present and potential use of fluids from the disposal or affected aquifer formations in the general area.

(4) Volume, rate and injection pressure of the fluid to be injected.

(5) The following geologic and physical characteristics of the injection interval and the overlying and underlying impermeable barriers:

(aa) Thickness.

(bb) Areal Extent.

(cc) Lithology (grain mineralogy, type and mineralogy of matrix, amount and type of cement, clay content, clay mineralogy).

(dd) Effective porosity and how determined.

(ee) Permeability, vertical and horizontal, and how determined, i.e., mechanical (electrical) logs, core analyses, formation tests.

(ff) Coeffictent of storage of aquifer.

(gg) Amount and extent of natural fracturing.

(hh) Location, extent and effects of known or suspected faulting.

(i1) Extent and effects of natural solution channels.

(jj) Flufd saturation.

(kk) Formation fluid chemistry with indications of local and regional vartations. 
(11) Temperature of formation and how determined.

(mm) Formation and fluid pressures, original and modifications resulting from previous fluid withdrawals.

(nn) Fracturing gradients.

(oo) Osmotic characteristics of rock and fluids both comprising and contiguous to the reservoir, and an indication of the effect of injected wastes on contiguous formations in the event of leakage.

(pp) Diffusion and dispersion characteristics of the waste and formation fluid, including effect of gravity segregation.

(qq) Compatibility of injected waste with physical, chemical and biological characteristics of the reservolr.

(6) The following engineering data concerning the well:

(aa) Size of hole and estimated total depth of well.

(bb) Type, size, weight, strength, and related data in respect to all surface, intermediate and production casing.

(cc) Specifications and proposed installation of tubing and packers.

(dd) Proposed cementing procedures and type of cement.

(ee) Proposed coring program.

(ff) Proposed information testing program.

(gg) Proposed injection procedure, i.e., open hole, perforated casing.

(7) Plans for monftoring the system and, if the system is a deep disposal well, the plans for monitoring injection pressures and formation pressures, i.e., injection wells and observation wells.

(8) Expected changes in pressure, rate of fluid displacement by injected wastes, directions of dispersion and area affected by the system.

(k) Such other and further data as the Comission may reasonably request. An applicant may upon its own initiative, and when requested by the Commission, an applicant shall furnish an opinion of independent experts, satisfactory to the Commission, in respect to the accuracy and completeness of any information or data furnished by the applicant and on any aspect of the applicant's disposal system or the contemplated operation or effects thereof.

\section{Section 5. - PRELIMINARY REVIEW OF APPLICATIONS}

(a) The Commission recognizes that the accumulation of the informetion and data required to complete an application under Section 4 of these Rules and Regulations may involve considerable expense to an applicant. Therefore, and merely as a convenience to applicants, the Commission will accept for preliminary 
review applications setting forth in general terms the information specified in Section 4, but the same shall be set out in sufficient detail so as to enable the Commission to determine the general feasibility of a proposed system. Such applications shall be clearly designated as "for preliminary review" under authority of this Section.

(b) The Commission may rule upon applications submitted for preliminary review and either approve or disapprove the feasibility of the proposed system. The approval or disapproval by the Commission upon preliminary review of applications shall in no way affect the right of an applicant to subsequently submit an application or applications contalning the data required by Section 4 of these Rules and Regulations. The Commission shall not be bound by its ruling upon any application submitted for preliminary review.

\section{Section 6. - PROCEEDINGS BEFORE THE COMMISSION - NOTICE - PUBLIC HEARING.}

(a) Before any finding upon an application, or application for rehearıng, or order, or amendment of an order shall be made by the Commission under these Regulations, there shall be held a public hearing upon at least twenty (20) days notice at such time and place as may be prescribed by the Commission and any person interested in the action of the Commission shall be entitled to appear and be heard; except, when an emergency requiring immediate action is found to exist by the Commission, the Commission may issue an emergency order without notification of the hearing, which shall be effective upon promulgation, but shall remain effective for no more than twenty (20) days.

(b) The Commission shall rause notice of every public hearing to be given by personal service to each surface and mineral owner of record within a two (2) miles radius of any subsurface disposal system which may be the subject of any proceeding before the Comrission, or it may give such notice by one publication in a newspaper of general circulation in the City and County of Denver, Denver, Colorado, and in a newspaper of general circulation in the County where the land affected by a subsurface disposal system, or some part thereof, is situated. Sald notice shall be issued in the name of the State of Colorado, shall be signed by the Commission, or the Technical Secretary of the Commission, and shall specify the style and number of the proceedings, the time and place of the hearing, and shall briefly state the purpose of the proceeding.

(c) If notice is given by personal service, such service shall be made by an officer appointed to serve summons, or by an agent of the Commission, in the same manner and extent as is provided by law for the service of summons in civil actions in the District Courts of this State. Proof of service by such agent shall be by his affidavit and proof of service by any officer shall be in the form required by law with respect to service of summons in civil actions.

(d) In addtition to the notice required to be given by the Commifsion under subparagraph (b) of this Section, notice of every application filed with the Commission shall be given by the applicant by mailing or delivering a copy of the application to each surface and mineral owner of record within two (2) miles of any proposec subsurface disposal system. Such notice shall be melled or delivered on or before the date the application is filed with the Commission. An affidavit shall be attached to the application showing the parties to whom the notice required by this subsection has been served, and their respective addresses. 
(e) The Commission shall designate a hearing officer, as provided in the Act, who shall make findings and recommendations to the Commission in respect to any matter pertaining to a subsurface disposal system.

(f) The Commission may, on its own motion, or upon the request of any Interested person, institute a proceeding to prevent a violation of the Act, or of any order, rule or regulation of the Commission relating to a subsurface djsposal system, $\tau_{\perp}$ for the amendment of any order, rule or regulation, by notice of hearing, or Issuance of an emergency order to show cause directed to and served upon any person or persons charged with violating the same.

(g) Hearings before the Comnission shall be concucted without rigid formality. A transcript of testimony shall be taken and preserved as part of the permanent record of the Commission. Any person testifying before the Comnission or in support of an application or in opposition thereto shall be required to do so under oath or affirmation. Full opportunity shall be afforded all interested parties at a hearing to prevent evidence and to cross-.examine witnesses. In general, the rules of evidence applicable before a trial court without a jury shall be applicable, providing that such rules may be relaxed, where by so doing, the ends of justice will be better served.

Section 7. - TERMINATION, ABANDONMENT - No sudsurface disposal system subject to these Regulations shall be terminated or plugged and abandoned except after notice and hearing. Every plugging and abandonment shall be accomplished in accordance with the orders of the Commission. Monitoring equipment shall be operated after termination or abandonment for as long as the Commission may reasonably require, which operation shall be at the sole risk, cost, and expense of the person responsible for the disposal system.

Section 8. - WAIVER OF BASIC STANDARDS - Any person operating a subsurface disposal system under an effective permit issued pursuant to these Rules and Regulations shall not, as a result of the discharge from that system, be deemed to be in violation of the Basic Standards applicable to all the waters of this State.

Section 9. - RELEASE OF SECURITY - When any person constructing or operating

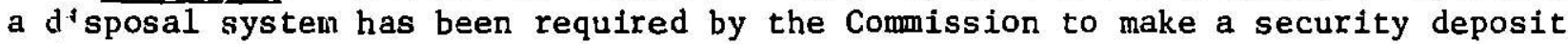
and when that person can affirmatively demonstrate to the Commission that said disposal system has been finally terminated and all reasonable measures have been taken to protect the waters of the State from pollution, the Commission shall, by order, direct the Treasurer of the State of Colorado to release such security deposit.

Section 10. - OTHER REGULATORY AGENCIES - Nothing in these Regulations shall relieve a person making application to the Commission from complying with all applicable rules and regulations of other government agencies, whether State or Federal.

Section 11. - RESPONSIBILITY - Compliance with the Rules and Regulations contained herein shall. In no way be deemed to relieve any person of any liabllity, obligation or duty Imposed on such person by statute or the common law.

Section 12. - RELIANCE UPON OTHER AGENCIES - The Commission and the Division of Admintstration shall freely consult with such other State and Federal 
agencies and departments, including the Colorado State Planning office, as it or the Division of Administration of the Commission may deem necessary for a proper determination of any matter subject to these Regulations. Notice of hearing before the Commission or before a hearing officer derignated by the Commission shall be given to interested State and Federal agencies and departments. 


\section{APPENDIX D.}

Policy Statement on the Underground Injection of Wastewaters Adopted by the Ohio River Valley Sanitation Commission

(ORSANCO)

WHEREAS: Underground injection f.s a technically acceptable method of wastewater disposal or long-term storage whereby pollutants can be removed from the surface environment and p.laced in isolated underground locations; and

WHEREAS: The techniques, trained personnel and organizations are available within the ORSANCO district for evaluation of the geologic and engineering feasibility of underground disposal and for determination of the risks, if any, that may exist to public health and to the environment;

NOW, THEREFORE: Let it be resolved that the Oh10 River Valley Water Sanitation Commission does declare as a policy that wastewater injection may be used when the regulatory authorities with legal jurisdiction have considered other alternative methods of waste management, and that, after weighing all available evidence, have determined that:

I. Underground injection is the best avallable alternative in the specif Ic circumstances of the case;

II. Geologic and hydrologic conditions will, beyond a reasonable doubt, provide adequate protection of the public and natural resources;

III. The volume, chemical and physical composition, and toxicity of the fluid to be injected are compatible with the geologic and hydrologic conditions;

IV. The necessary safety factors and monitoring devices are incorporated in the design of the injection well and its auxiliary facilities;

V. The waste infection system will be operated in a manner compatible with the geologic conditions, waste character, and system construction;

VI. An approved alternative plan for waste management is avallable In the event that operational problems occur during the use of the injection system;

VII. The infection well w1ll be properly plugged and marked before abandonment;

VIII. A permanent public record wili be kept which documents the complete operational history of the injection system.

\footnotetext{
ॠ Adopted January 11, 1973.
} 
Seven steps are identifled as essential in the administration of a scate program for regulation of the underground injection of wastewater. An add1tional step is recommended for wells located near state boundarles. The steps are:

1. Freliminary assessment by the applicant of the geology and geohydrology at the proposed well site and the suitability of the wastewater for injection. These initial studies should be made in consuitation with the appropriate scate agencies;

2. Application to the state agency with legal jurisdiction for permisston to drill and test a well for subsurface wastewater injection. The application must be supported by a report that documents all details of the proposed injection system, including monttoring and emergency standby facilities. On Issuance of a permit, the applicant will be informed of the geoiogic and geohydrologic parameters that will be employed by the state in reaching 1 ts final determination on feastbility of wastewater injection into the well, anticipated limitations on injection pressure and injected volumes, the probable monitoring requirements, and probable requirements for alternative wastewater management programs in the event that operational problems occur during the use of the injection well;

3. Drilling and evaluation of the well and submission of samples, logs, test information, and a well-completion report to the state;

4. Request by the applicant for approval to infect wastewater into the well. The request should indicate any changes from the original plan in system construction and operating program;

5. Evaluation by the state agency of the proposal on the basis of which It would issue elther approval, approval-with-modjfication, or disapproval of the proposed infection system with respect to the geologic, geohydrologic, and engineering data submitced. On approval, the applicant will be provided with specific instructions as to the opcrating restrictions and monitoring requirements:

6. Issuance of Instructions for operation of the infection system. This embraces requirements that the regulatory agency must be notified immediately if operational problems occur, if remedial work 18 required, or if significant changes in the wastewater stream are anticipated.

7. Procedures for abandonment of the well in accordance with state regulations;

8. Where a proposed infection aystem is to be located within five miles of a state border, the appropriate regulatory agency in the adjacent state should be provided with an opportunity to review and comment on the application. Further, this agency should be posted when any significant problems occur during the operation of such a system. 
APPENDIX E.

\author{
Administrator's Decision Statement $\# 5^{*}$
}

Subsurface Emplacement of Fluids

The Environmental Protection Agency in concert with the objectives of the Federal Water Pollution Control Act as ameisded (33 U.S.C. 1251 et seq.; 36 Stat. 816 et seq.; Publ L. 92-500) ". . . to restore and maintain the chemical, physical, and blological integrity of the Nation's Water" has establisined an EPA policy on Subsurface Emplacement of Fluids by Well Injection" which was issued internally as Administrator's Decision Statement No. 5. The purpose of the policy is to establish the Agency's concern with this technique for use in fluid storage and disposal and its position of considering such fluid emplacement only where $1 \mathrm{t}$ is demonstrated to be the most environmentally acceptable available method of handling flutd storage or disposal. Publication of the Policy as information establishes the Agency's position and provides guidance to other Federal Agencies, the States, and other interested partles.

Accompanying the Policy statenent are "Recommended Data Requirements for Environmental Evaluation of Subsurface Emplacement of Flulds by Well Injection well system; and to insurements ${ }^{\star \star}$ is to provide guidance for potential injectors and regulatory agencles concerning the kinds of Information required to evaluate the prospective infections well system; and to insure protection of the environment. The Recommended Data Requirements require sufficient information to evaluate complex injection operations for hazardous materials, but may be modifled in scope by a regulatory agency for other types of injection operations.

The EPA recognizes that for certain industries and in certain locations the disposal of wastes and the storage of fluids in the subsurface by use of well injection may be the most environmentally acceptable practice avallable. However, adherence to the policy requires the potential infector to clearly demonstrate acceptability by the provision of technical analyses and data fustifying the proposal. Such demonstration requires conventionsl engineering and other analyses which indicate beyond a reasonable doubt the efficiency of the proposed infection well operation.

Several issues within the policy should be highlighted and explained to avoid confusion. One of the goals of the policy 18 to protect the integrity of the subsurface environment. In the context of the policy statement, integrity means the prevention of unplannei fracturing or other physical impairment of the geologic formations and the avoldance of undesirable changes in aquifers, mineral deposits or other resources. It is recognized that fluid emplacement by well injection may cause some change in the enviroment and, to some extent, may preempt other uses.

Emplacement 18 intended to Include both disposal and storage. The difference between the two terms is that storage implies the existence of a plan for recovery of the material within a reasonable time whereas disposal implies that no recovery of the material is planned at a given site. Elther operation

\footnotetext{
"Federal Regluter, Vol. 39, No. 69, Tuesday, Apr11 9, 1974, p. 1292'.

"Wording and punctuation as or 1 ginally printed.
} 
would require essentially the same type of information prior to injection. However, the attitude of the appropriate regulatcry agency toward evaluation of the proposals would be different for each type operation. The EPA policy recognizes the need for Injection wells in certain oil and mineral extraction and fluid storage operations but requires suffictent environmental safeguards to protect other uses of the subsurface, both during the actual injection operation and arter the injection has ceased.

The policy considers waste disposal by well injection to be a temporary means of disposal in the sense that is approved only for the 1ife of an issued permit. Should more environmentally acceptable disposal technology become avallable, a change to such technology would be required. The term "temporary" is not intended to imply subsequent recovery of injected waste for processing by another :echnology.

Paragraph 5 of the policy and program guidance provides that EPA will apply the policy to the extent of its authoritles in conducting all EPA program activities. The applicablifty of the policy to participation by the several States in the NPDES permit program under section 402 of the Federal Water Pollution Control Act as amended has been established previously by 5124.30(d) of Part 124 entitled "State Program Elements Necessary for Participation in the National Pollutant Discharge Elimination System," 37 FR 23380 (December 22, 1972). These guidelines provide that each EPA Regional Administrator must distribute the policy to the Director of a State water discharge permit lsouing agency, and must utillze the policy in his own review of any permits for disposal of pollutants into wells that are proposed to be 1ssued by States participat:ing in the NPDES.

EPA Pollcy on Subsurface Emplacement of Fluids by Well Injection

This ADS records the EPA's position on injection wells and subsurface emplacement of fluids by well injection, and supercedes the Federal Water Quality Administrations order COM 5040.10 of October 15, 1970.

Goals. The EPA Pollcy on Subsurface Emplacement of Fluids by Well Infection is designed to:

(1) Protect the subsurface from pollution or other environmental hazards attributable to improper infection or 1ll-sited infection wells.

(2) Ensure that engineering and geological safeguards adequate to protect the integrity of the subsurface envirunment adhered to in the preIIminary investigations, design, construction, operation, monitoring and abandonment phases of injection well projects.

(3) Encourage developwent of alternative means of disposal which af ford greater environmental protoction.

Principal findinge and policy rationale. The available evidence concerning injection wells and subsurface emplacement of fluids indicates that:

(1) The emplacement of fluids by subsurface infertion of ten to considered by government and private sgencies as an attractive mechanlom for final ditsposs or storage owing to (a) the diminishing cepabilities of surface 
waters to recelve effluents without violation of quality standards, and (b) the apparent lower costs of this method of disposal or storage over conventional and advanced waste management techniques. Subsurface storage capacity is a natural resource of considerable value and like any other natural resource its use must be conserved for maximal benefits to all people.

(2) Improper injection of municlpal or industrial wastes or injection of other fluids for storage of disposal to the subsurface environment could result in serious pollution of water supplies or other environmental hazards.

(3) The effects of subsurface injection and the fate of injected materials are uncertain with today's knowledge and could result in serious pollution or environmental damage requiring complex and cost.ly solutions on a longterm basis.

Policy and program guidance. To ensure accomplishment of the subsurface protection goals established above it is the policy of the Environmental Protection Agency that:

(1) The EPA will oppose emplacement of materlals by subsurface infection without strict controls and a clear demonstration that such emplacement will not interfere with present or potential use of the subsurface environment, contaminate ground water resources or otherwise damage the environment.

(2) All proposals for subsurface injection should be critically evaluated to determine that:

(a) All reasonable alternative measures have been explored and found less satisfactory in terms of environmental protection;

(b) Adequate preinjection tests have been made for predicting the fate of materials injected;

(c) There is conclusive technical evidence to demonstrate that such injection will not interfere with present or potential use of water resources nor result in other environmental hazards;

(d) The subsurface injection system has been designed and constructed to provide maximal environmental protection;

(e) Provisions have been made for monitoring both the infection operation and the resulting effects on the environment;

(f) Contingency plans that will obviate any environmental degradation have been prepared to cope with all well shut-1ns or any well fallures;

(g) Provision will be made for supervised plugging of infection wells when abandoned and for monitoring to ensure continuing environmental protection. 
(3) Where subsurface injection is practiced for waste disposal, it will be recognized as a temporary means of disposal until new technology becomes ava."able enabling more assured environmental protection.

(4) Where subsurface injection is practiced for underground storage or for recycling of natural fluids, it will be recognized that such practice will cease or be modified when a hazard to natural resources or the environment appears imminent.

(5) The EPA will apply this policy to the extent of its authorities in conducting all program activities, including regulatory activities, $x$ : search and development, technical assistance to the States, and the administration to the construction grants, State program grants, and basin planning grants programs and control of pollution at Federal facilities In accordance with Executive order 11752.

Recommended Data Requirements for Environmental Evaluation of Subsurface Emplacement of Fluids by Well Injection

The Administrator's Decision Statement No. 5. on subsurface emplacement of fluids by well injection has been prepared to establish the Agency's position on the use of this disposal and storage technique. To aid in implementation of the policy a recommended data base for environmental evaluation hás been developed.

The following parameters describe the information which should be provided by the injector and are designed to provide regulatory agencies sufficlent information to evaluate the environmental acceptability of any proposed well injection. A potential injector should initially contact the regulatory authority to decermine the preliminary investigative and data requirements for a particular infection well as these may vary for dirferent kinds of injection operations. The appropriate regulatory authority will specify the exact data requirements on a case by case basis.

(a) An accurate plat showing location and surface elevation of proposed infection well site, surface features, property boundaries, and surface and mineral ownership at an approved scale.

(b) Maps Indicating location of water wells and all other wells, mines or artificlal penetrations, 1ncluding but not limited to ofl and gas wells and exploratory or test well, showing depths, elevations and the deepest formation penetrated within twice the calculated zone of influence of the proposed project. Plugging and abandonment records for all ofl and gas tests, and water wells should accompany the riap.

(c) Maps Indicating vertical and lateral limits of potable water supplies which would include both short and long-term variations in surface water supplies and subsurface aquifers containing water with less than $10,000 \mathrm{mg} / 1$ total dissolved solids. Avallable amounts and present and potential uses of these waters, as well as projections of public water supply requirements, must be considered.

(d) Descriptions of mineral resources present or belleved to be present in area of profect and the effect of this profect on present or potential mineral 
resources in the area.

(e) Maps and cross sections at approved scales 1llustrating detailed geologic structure and a stratigraphic section (including formations, lithology, and physical characteristics) for the local area, and generalized maps and cross sections illustrating the regional geologic setting of the project.

(f) Description of chemical, physical, and blological properties and characteristics of the fluids to be injected.

(g) Potentiometric maps at approved scales and isopleth intervals of the proposed injection horizon and of those aquifers immediately above and below the injection horizon, with copies of all drill-stem test charts, extrapolations, and data used in compiling such maps.

(h) Description of the location and nature of present or potentially useable minerals from the zone of influence.

(i) Volume, rate, and injection pressure of the fluid.

(j) The following geological and physical characteristics of the injection interval and the overlying and underlying confining beds should be determined and submitted:

(1) Thickness;

(2) areal extent;

(3) lithology;

(4) grain mineralogy;

(5) type and mineralogy of matrix;

(6) clay content;

(7) clay mineralogy;

(8) effective porosity (Including an explanation of how determined);

(9) permeability (including an explanation of how determined):

(10) coefficient of aquifer storage;

(11) amount and extent of natural fracturing;

(12) location, extent, and effects of known or suspected faulting indicating whether fauj.ts are sealed, or fractured avenues for fluid movement;

(13) extent and effects of natural solution channels;

(14) degree of fluid saturation;

(15) formation fluid chemistry (including local and regional variations);

(16) temperature of formation (including an explanation of how determined);

(17) formation and flutd pressure (including original and modifications resulting from fluid withdrawal or infection);

(18) fracturing gradients;

(19) diffusion and dispersion characteristics of the waste and the formation fluid Including effect of gravity segregation;

(20) compatiblity of injected waste with the physical, chemical, and biological characteristics of the reservolr, and

(21) injectivity prufiles.

(k) The following englneering data should be supplied: 
(1) Diameter of hole and total depth of well;

(2) type, size, weight, and strength, of all surface, Interwediate, and injection casing strings;

(3) speciffcations and proposed installation of tubing and packers;

(4) proposed cementing procedures and type of cement;

(5) proposed coring program;

(6) proposed formation testing program;

(7) proposed logging program;

(8) proposed artificial fracturing or stimulation program;

(9) proposed injection procedure;

(10) plans of the surface and subsurface construction details of the system including englneering drawings and specifications of the system (including but not limited to pumps, well head construction, and casing depth);

(11) plans for monttoring including a multipolnt fluid pressure monitoring system constructed to monitor pressures above as well as within the injection zones; description of annular fluid; and plans for maintaining a complete operational history of the well; (12) expected changes in pressure, rate of native fluld displacement by injected fluid, directions of dispersion and zone affected by the project;

(13) contingency plans to cope with all shut-ins or well failures in a manner that will obviate any environmental degradation.

(1) Preparation of a report throughly investigating the effects of the proposed subsurface injection well should be a prerequisite for evaluation of a project. Such a statement should include a thorough assessment of: (1) the alternative disposal schemes in terms of maximum environmental projection;

(2) profection of fluid pressure reoponse with time both in the injection zones and overlying formations with particular attention to aquifers which may be used for fresh water supplies in the future; and (3) problems assoclated with possible chemical interactions between injected wastes, formation fluids, and mineralogical constituents. 


\section{REFERENCES}

AECM 0524

Atomic Energy Commission Manual, Chapter 0524

AECR

Atomic Energy Commission Reports, Vol. 7, Opinions and Decisions of the Atomic Energy Commission with Selected Orders, January 1, 1974 to June 30 , 1974, U.S. Government Printing office, Washington, D.C., p. 118 (1975).

ADS \#5

Administrator's Decision Statement \#5, Fed. Regist., 39, No, 69 (Tuesday, April 9, 1974).

AGNS

Barnwell Nuclear Fuels Plant Environmental Report, Construction Permit Stage, Allied-Gulf Nuclear Services, DOCKET 50-332, pp. 6, 8

(November 1971).

API 1955

American Petroleum Institute, Selection and Evaluation of Well Completion Methods, Am. Petroleum Institute, Division of Production, Dallas, Texas (1955)

API 1958

American Petroleum Institute, Problems in the Disposal of Radioactive Wastes in Deep We1ls, Am. Petroleum Institute, Dallas, Texas (1958).

API 1973

American Petroleum Institute, Specification for Casing, Tubing, and Drill Pipe, Thirty-Second Edition, Am. Petroleum Institute, Spec. 5A, API, Dallas, Texas (1973).

API 1975

American Petroleum Institute, Jolnt Association Survey of the U.S. 01l and Gas Producing Industry -1973 , Section I, Drilling Costs, American Petroleum Institute, Washington, D.C. (1975).

ARLIN

2. E. Arlin, "Deep Well Disposal of Uranlum Tailing Water," in 2nd Conf. on Ground Disposal of Radioactive Wastes, Chalk River, Canada, 1961, J. M. Morgan, Jr. et. al., eds., USAEC Report TID-7628, pp. 356-362 (1902).

\section{BARBREAU}

A. Barbreau, "Possibillties of Injection or Radioactive Wastes Into Deep Permeable Geologic Formations," SM-93/44, In Disposal of Radioactive Wastes Into the Ground, STI/PUB/156, IAEA, VIenna, p. 607 (1967). 
BARR

F. J. Barr, Jr., "Feasibility Study of a Seismic Reflection Monitoring System for Underground Waste - Material Injection Sites," in Underground Waste Management and Artificial Recharge, J. Braunstein, ed., Am. Assoc. Petroleum Geologists, Inc., Tulsa, 0lka., p. 207 (1973).

BEAR 1964

J. Bear and M. Jacobs, The Movement of Injected Water Bodies in Confined Aquifers: Underground Water Storage Study Report No. 13, Technion, Haifa, Israel (1964).

BEAR 1972

J. Bear, Dynamics of Fluids in Porous Media, Elsevier Pub. Co., New York (i972).

\section{BEIKMAN}

H. M. Belkman, Geology of the Powder River Basin, Wyoming and Montana, with Reference to Subsurface Disposal of Radioactive Wastes, U.S. Geological Survey Trace Elements Inv. Report 823 (open file) (1962).

\section{BELTER}

W. G. Belter, "Deep Disposal Systems for Radioactive Wastes," Presented at the Symposium on Underground Waste Management and Environmental Implications, sponsored by the Am. Assoc. Petroleum Geologists and the U.S. Geological Survey, Houston, Texas (Dec. 8, 1971).

\section{BERGSTROM}

R. E. Bergstrom, Feasibility of Subsurface Disposal of Industrial Wastes

in Illinois: Illinols State Geological Survey Circular 426 (1968).

BERRY

F. A. F. Berry, "High Fluid Potentials in California Coast Ranges and Their Tectonic Significance," Bull. Am. Assoc. Pet. Geol. 571219 (1973).

BIXEL

J. C. Bixe1, "Catalytic Exchange Detritiation studies," in Tritium Effluent Control Project Progress Report: April-June 1974, USAEC Report MLM-2171(LD), p. 17 (September 1974).

BLACK

Black, Crow, and Eldsness, Inc., Engineering Report on Modification to Deep-Well Disposal System: Effect of Monitoring Wells and Future Monitoring Requirements for Sugar Cane Growers Cooperative of Florida, Belle Glade, Palm Beach County, Florida, Black, Crow, and Eidsness, Inc., Eng. Report Project No. 387-71-01 (1972).

BLUM

H. Blum, "Casing Program," in Fundamentals of Rotary Drilling, The Petroleum Englneering Publishing Co., Dallas, Texas (1959).

BOND 1972

D. C. Bond, Hydrodynamics in Deep Aquifers of the Illinois Basin: Illinois State Geological Survey C1rcular 470 (1972). 
BOND 1973

D. C. Bond, "Deduction of Flow Patterns in Variable-Density Aquifers from Pressure and Water-Level Observations," in Underground Waste Management and Artificial Recharge, J. Braunstein, ed., Am. Assoc. Petroleum Geologists, Inc., Tulsa, 0kla., p. 357 (1973).

BONNER

W. F. Bonner, Battelle Pacific Northwest Laboratories, Richland, Washington, personal communication of January 24, 1975, to W. B. Seefeldt, Argonne National Laboratory, Argonne, Illinois.

BRADLEY

J. S. Bradley, "Abnormal Formation Pressure," Bull. Am. Assoc. Pet. Geol., 59(6), 957 (1975).

BRAUNSTEIN

J. Braunstein, ed., Undergiound Waste Management and Artificial Recharge, Preprints of papers presented at the Second International Symposium on Underground Waste Management and Artificial Recharge, Sponsored jointly by the American Association of Petroleum Geologists, The United States Geological Survey, and the International Association of Hydrological Sciences, Naw Orleans, La., September 1973, Am. Assoc. Petroleum Geologists, Inc., Tulsa, Okla. (1973).

\section{BREDEHOEFT}

J. D. Bredehoeft and G. F. Pinder, "Application of Transport Equations to Groundwater Systems," in Underground Waste Management and Environmental Implications, T. D. Cook, ed., A.A.P.G. Memoir 18, Am. Assoc. Petroleum Geologists, Inc., p. 191 (1972).

BROWN

D. L. Brown and W. D. Silvey, "Underground Storage and Retrieval of Fresh Water from a Brackish-Water Aquifer," In Underground Waste Management and Artificial Recharge, J. Braunstein, ed., Am. Assoc. Petroleum Geologists, Inc., Tulsa, Okla., p. 379 (1973).

BUCHANAN

Nuclear Safety Staff, "Regulation of Nuclear Power and Related Facilities," J. R. Buchanan, ed., in Nucl. Saf. 15(1), 1 (1974).

BUDNITZ

R. J. Budnitz, "Tritium Instrumentation for Environmental and Occupational Monitoring. A Review," Health Phys. 26(2), 165 (1974).

BURGER 1973

L. L. Burger and J. L. Ryan, Technology of Tritium Flxation and Storage, USAEC Report BNWL-1807 (January 1973).

\section{BURGER 1975}

L. L. Burger, Battelle Pacific Northwest Laboratory, personal communication, November 1975. 
BUSCHBACH

T. C. Buschbach, Cambrian and Ordovician Strata of Northeastern Illinois: Illinois Geological Survey Report of Investigation 218 (1964).

CFR

USAEC Division of Radiation Protection Standards, Code of Federal Regulations, Title 10, Part 20, Standards for Protection Against Radiation, Appendix B, Table II (Dec. 10, 1969).

CHITWOOD

R. Chitwood, USNRC, private communication (1975).

CLEBSCH

A. Clebsch, Jr. and E. H. Baltz, "Progress in the United States of America Toward Deep-Well Disposal of Liquid and Gaseous Radioactive Wastes," SM-93/44, in Disposal of Radioactive Wastes Into the Ground, STI/PUB/156, IAEA, Vienna (1967).

\section{CLIFFORD 1972}

M. J. Clifford, Feasibility of Deep-Well Injection of Industrial Wastes in Ohio, Ohio State University, unpublished M.S. thesis (1972).

CLIFFORD 1973

M. J. Clifford, "Hydrodynamics of the Mount Simon Sandstone, Ohio and Adjoining Areas," in Underground Waste Management and Artificial Recharge, J. Braunstein, ed., Am. Assoc. Petroleum Geologists, Inc., Tulsa, Okla., p. 349 (1973).

COHEN

J. J. Cohen et al., "Disposal of Radioactive Waste in Deep S1licate Rock," in IEEE Trans. on Nuc. Sc1. NS-19(1), 172 (1972).

COLTON

G. W. Colton, Geologic Summary of the Appalachian Basin, with Reference to the Subsurface Disposal of Radioactive Waste Solutions, U.S. Dept. of the Interior Geological Survey, TEI-791 (June 1961).

COOK

T. D. Cook, ed., Underground Waste Management and Environmental Implications, Symposium sponsored jointly by The American Association of Petroleum Geologists and the U.S. Geological Survey, Houston, Texas, December 1971, Am. Assoc. Petroleum Geologists, Tulsa, Okla. (1972).

$\operatorname{cox}$

From a preliminary draft, "Deep-Well Disposal: Institutional, Physical, and Economic Considerations," representing the results of an extensive study by W. E. Cox, J. E. Hackett, B. F. Long, and W. R. Walker, Virginia Water Resources Research Center, Virginia Polytechnic Institute and State University, Blacksburg, Va., sponsored by the National Science Foundation Program of Research Applied to National Needs, Grant GI-34815.

\section{DAVIS}

S. H. Davis and R. J. M. De We1st, Hydrogeology, W1ley and Sons, Inc., New York, N.Y. (1966). 


\section{DEBUCHANANNE}

G. D. DeBuchananne, "Activities of the Geological Survey, United States Department of the Interior, in the Search for a Geologic Environment Suitable for the Management of High-Level Radioactive Waste," In Proc. Symp. on the Management of Radioactive Wastes irom Fuel Reprocessing, Paris, November 27 - December 1, 1972, Organization for Economic Cooperation and Development, Paris, p. 873 (March 1973).

DELAGUNA 1968A

W. DeLaguna, "Importance of Deep Permeable Disposal Formations in Location of a Large Nuclear-Fuel Reprocessing Plant," in Subsurface Disposal in Geologic Basins-A Study of Reservoir Strata, J. E. Galley, ed., A.A.P.G. Memoir 10, Am. Assoc. Petroleum Geologists, Inc., Tulsa, Okla. p. 21 (1968).

\section{DELAGUNA 1968B}

W. DeLaguna et al., Engineering Development of Hydraulic Fracturing as a Method for Permanent Disposal of Radioactive Wastes, USAEC Report ORNL4259 (August 1968).

DELAGUNA 1972

W. DeLaguna, Hydraulic Fracturing Test at West Valley, New York, USAEC Report ORNL-4827 (October 1972).

DICKINSON

G. Dickinson, Geological Aspects of Abnormal Reservoir Pressures in the Gulf Coast Louisiana, Bull. Am. Assoc. Petr. Geol., 37(2), 410 (1953).

DOCKET RM-50-2

U.S. Nuclear Regulatory Commission, Rulemaking Hearing, Numerical Gui.des for Design Objectives and Limiting Conditions for Operation to Meet the Criterion "As Low As Practicable" for Radioactive Material in Light-Water Cooled Nuclear Power Reactor Effluents, DOCKET No. RM-50-2.

DOCKE'T-50201-28

Nuclear Fuel Services, Inc., West Valley, N.Y., Waste Disposal Well No. 1 Data (January 1970).

\section{ELLIS}

R. E. E1lis, "Tritiated Liquid Waste Decontamination," In Tritium Effluent Control Project Progress Report: April-June 1974, USAEC Report MLM-2171(LD), p. 13 (September 1974).

ENR

Engineering News Record, "Building Cost Index History 1913-1974," Engr. News-Rec. 194(12), 63 (Mar. 1975).

ERDA

U.S. Energy Research \& Development Administration, Alternatives for Managing Wastes from Reactors and Post-Fission Operations in the LWR Fue 1 Eycle, ERDA-76-43 (May 1976). 
FERTL

W. H. Fertl et al., "A Look at Cement Bond Loge," J. Pet. Techncl. 26, 607 (1974).

GALLEY

J. E. Galley, ed., Subsurface D1sposal in Geologic Basins-A Study of

Reservoir Strata, A.A.P.C. Memolr 10, Am. Assoc. Petroleum Geolog1sts, Iac., Tulsa, Okla. (1968).

GARCIA-BENGOCHEA

J. I. Garcla-Bengochea et al., "Artificlal Recharge of Treated Hastewaters and Rainfall Runoff Into Deep Saline Aquifers of Peninsula of Florida," In Underground Waste Management and Artificial Recharge, J. Braunstein, ed., Am. Assoc. Petroleum Geologists, Inc., Tulsa, Okla., p. 505 (1973).

GARONO

L. E. Garono, Denver Earthquakes, U.S. Dept, of Comerce, AD-713526 (1970).

GATLIN

C. Gatlin, Petroleum Englneeriroi Drilling and Nell Completions, PrenticeHall, Inc., Englewood Cliff 8, N.J. (1960).

\section{GELHAR}

L. W. Gelhar et al., Density Induced Mixing in Confined Aquifers. U.S. Environmental Protection Agency, Water Pollution Control Research Series Publication 16060 ELJ 03/72 (1972).

COODE

J. H. Goode (coap11. ed.), R. D. Baybarz. S. D. Clinton, L. C. Farrat, C. L. Fltrgerald, R. G. Halre, V. J. Tennery, V. C. A. Vaughen, and C. D. Hatson, Voloxidation - Removal of Volatile Fiseion Products from Spent LMFBR FUals. USAEC Report ORNL-TH-3723 (January 1973).

COOLSBY 1971

D. A. Coolsby, "Hydrogeochenical Effects of Injecting Wastes Into a Libestone Aquifer Near Pensacola, Flor1da," Groundwater $\underline{9}(1), 13$ (1971).

COOLSBY 1972

D. A. Cooleby, "Gecchentcal Effects and Movenent of Injected Industrial Waete In a Libestone Aquifer," In Undarground Weote Manereant and Environ-

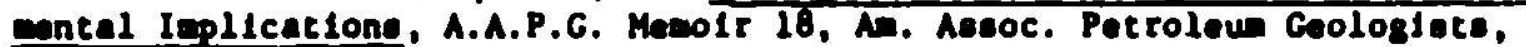
Inc., Tules, OkIa, p. 355 (1972).

GRANT

E. L. Grant and H. G. Ireson, Princlplee of Bnglaeering Economy, Yourth ed., The Ronald Prees Co., Nev Yurk (1960).

\section{GROSMNGIN}

H. Grosenangln et al., "A Sondc Mathod for Amalyzing the quallty of Camentation of Borehole Caelnge," J. Pec. Tachnol. 13. 165 (1961). 
HANBY

K. P. Hanby and R. E. Kidd, "Subsurface Disposai of Liquid Industrlal Wistes in Alabama - A Current Status Report," in Underground Waste Management and Artiflclal Recharge, i. Braunsteln, ed., Am. Assoc. Petroleum Geologists, Inc.. Tulsi, Oklia., p. 72 (1973).

HANSHAW

B. B. Hanshaw, "Natural Membrane Phenomena and Subsurface Haste Emplacement," in IInderground Waste Management and Envi ronmental Implicat lons, T. D. Couk, id., A.A.P.G. Memo1r 18, Am. Assoc. Petroleum Geologists, Inc., Tulsa, Okl.1., p. 308 (1972).

HAUN

I. D. Ilaun and L W. LeRoy, eds., Subsurface Geology in Petroleum Exploration, Colorado School of Mines, Golden, Colorado (1958).

HAYNES

C. D. Haynns, Pressurc-Fracture Gradient Problems in Deep Well Waste Disposal, University of Alabama Natural Resources Center, University of Alabama (1974).

HEALY

J. H. Healy, W. W. Rubey, D. T. Griggs, and C. B. Raleigh, "The Denver

Earthquakes". Science, 161(3848), 1301 (1968).

HIDALC(O)

R. V. Hidalgo and L. D. Hoodfork, "EDP as an Ald for Decision Making in Subsurface Infectlon of Liquid Wastes," In Underground Waste Management and Art $|f| c \mid a l$ Recliarge, J. Braunstein, ed. Am. Assoc. Petroleum Geologlste, Inc.. Tulsa, Okla., p. 133 (1973).

HIL.D

W. Mlld, "Deep-Well Disposal of Tritium Containing LIquid Effluents," In Proc. Symp. on the Manugement of Radloactlve Hastes from Fuel Reprocessing, Par 18, Novumer 27 - December 1, 1972, Organizat Ion for Economic Cooperation and Develupment, Paris, P. 1003 (1973). See also KFK-1744.

HOL.LOWAY

H. D. Holloway and J. R. Weaver. The Potentlal Contribut lon of Desalting to Future Hnter Supply in Texas, Annex 3: Manual of Procedure and Methuds for Calculal Ing Brine Dispoesl Costs. Southwest Research Institute. Hivuston, Texas $(1966)$.

HUBBERT

M. K. Hubbert and D. C. W1llle, "Mechantce of Hydraullc Fractuling," In Underground Haste Manarecant and Environeancal Implicat lons. T. D. Cook. ed., A.A.P.C. Memotr 18, Am. Aswoc. Petroleu Gologiace, Inc. Tulse, Okla. (1972).

ICT

Intermotional Critical Tables of Nuorlcal Data, Phyelce, Chedecry and Iechnology. Vol. V. MeGrm-HIII Book Cu.. Inc., Now York, P. 15 (1929).

INPILCO

Private Commication, Infllco Degrament Co., Oak Brook, Illinole (June 1975). 
I'JS

Illinois Water Supply, Feaslbility Study on Desaleing Hrackish Wilter I ron the Mt. Simon Aquifer in Northeastern llinols, Report of Contract Ni. 14-30-2924, U.S. Dept. of Interfor, Office of Saline Water, I1linuls Water Supply, Urbana, 111 inois (1973).

JANSSENS

A. Janssens, Stratigraphy of the Cambrian and Lower Ordoviclan Rocks in Oh10, Ohio Division of Geological Survey Bulletin 64 (1973).

JENNINGS

H. Y. Jennings and A. Timur, "Significant Contribut tons in Formation

Evaluation and Well Testing," J. Pet. Technol. 25, 1432 (1973).

KATL 1962

D. L. Katz, "Liquid-Waste Storage In Abnormal-Pressure Reservolrs," Nucleonics 20(4), 71 (1962).

Z̈ATZ 1963

D. L. Katz and D. L. Coates, Underground Storage of Fluids, Ulrich's Books, Inc., Ann Arbor, Michlgan (1968).

KAUFAAN

M. I. Kaufman et al., "Injection of Acidic Industrlal Waste in a Saline Carbonate Aquifer." In Underground Waste Management and Artificlal Recliarge, J. Braunstein, ed., Am. Assoc. Petroleum Ceologists, Inc., TulBa, Okla., p. 526 (1973).

KEHLE

R. O. Kehle. "The Determination of Tectonic Stresses Through Analysis of Hydraulic Hell Fracturing," J. Geophys. Res. 69(2), 259 (1964).

KERR

Kerr-McGee Corp. . Sequoyah Uranium Hexaf luoride Production Plant, DOCKET408027. Supplements 1-10, Kert-HcGee Corp., Oklahome City, Ok La.

KEYS $1973 A$

W. S. Keys and R. F. Brown, "Role of Borehole Gophysics In Underground Water Storage and Artificlal Racharge, In Undergrund Waste Managugent and Artificiel Recharge. J. Braunsteln, ed. An. Assoc. Petrolour Geolugists, Inc., Tulea, Okla.. p. 147 (1973).

KEYS 19738

W. S. Kaye and L. M. McCary, Location and Character!etlch of tho Interfact Becween Brine and Fresh Weter froa Geophyelcal Logh of Burehules in the Upper Breeos River Bedin, Texae. U.S. Guologlcal Survey Profeesional Paper 609-8 (1973).

\section{KORMLG 1958}

L. Kounis. Diepoeal of Seline Meter Convereion Brines--An Orlentaction seudy, U.s. Dept, of Intertor, Offlee of Sallne Tleter Research and Duvelopinent Report No. 20 (1958). 
Kil:NI): 1464

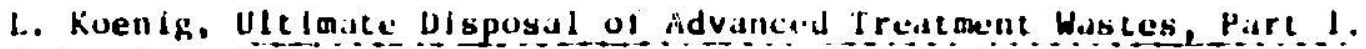

Inject Ion, L.S. Public Heal th Service, AWTR-B, y9g-HP-10 (14,i).

Kisii is

P. P. Kostil, "Cillculitions of Linderground Depusitories of Liquid : adluact Ive Wastes," Tratisliat in of pp. 31-35 from Pruccedings of SraenceTechn fcil conference held In Kulubzlieg. Poland October 2-7, 1972, Vul. 2 oRN1-L $t=2846$.

KRIF.DLER

W. L. Kriedler, New York State Genlogical Survey, private comonication.

KREIILER 1968

W. L. Kreldler, "Preliminary Study of Underground Dibposal of Industrial

Liquid Wagte In Niw York State," In Subsurface Disposal of Industrial

hastes, published and distributed by the Interstate uil Compact Comisaiun

ok lahoma Clty, Okla. (1968).

KRLSEMAN

G. P. Kruscman and N. A. De Ridder, Alialysis and Fvaluat lon of Punping

Tegt Data. Intcrnat lonal Institute for Land Reclaastion and Ioproictant, Bultei in 11. Wilgenlngers. The Netherlands (1970).

LAT IMER

H. M. Lit imer. The Oxidat Ion States of the Eltments and The1r Potencials in Aqueous Solutilins, 2nd Ed. Prent Ick-Hall, Inc.. Ner York (1952).

\section{LF.E.XHE.R}

J. A. Leenicer and R. L. Malcoln, "Case Histury ut Subeurface Heste Injectin of un Industrial Organic Haste." in Underground Wasce Manasegent and Art If Ic ial Rechirge, J. Braunstein, ed. An. Asnor. Putroleut Geologista. Inc.. Tulad, Okli..p. 565 (1973).

LF. GRAND

H. E. Le Grand, Geology and Ground-Hater Hydrology of the Aclantic and Gulf Coaetal Plain a Related to D. Sposal of Rediuact Ive Wastes. U.j. ceologlcal Survey Trace Elemente Inv. Report $005(1962)$.

LECROS 1969

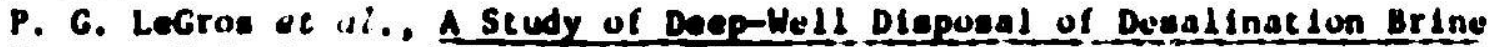
Haste. U.S. Dupt. of Interlor, Otlice of Saline Weter, Revearch and Duvalopant Progrees Rupurt No. 456 (1969).

LEGROS 1970

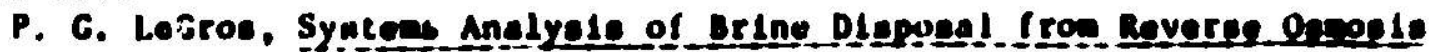

Planke, U.S. Dept. of Interlor. Offlce of Soline Heter. Rasearch and Dovoloptent Prograes Report No. 587 (1970).

\section{LICENS IMG}

USABC Cirectorate of Llcenoing. Fuole and Materlale, Envirunentel Survey of the ilucluar Fuul Cycle (Novesber 1972). 
LIN

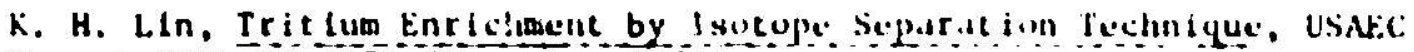

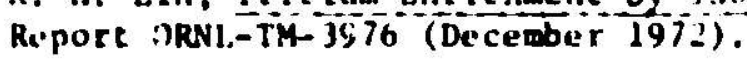

LOHMAY

S. H. Lohman, Ground-Water Hydralics, U.S. Ceoluglidl Survey Profession.t! Paper $708(197 \overline{2})$.

LOHSE

C. Lohse, Allied Chemlial Corp., Idaho Chemlcal Propribes-uperations office, Idaho Falls, Idaho, personal comeunication (June 1975).

LONG

J. T. Long. Englneering for Nuclear Fuel Reprocessling, Curdun and yreach Sclence Publishers Inc., New York, London, Paris (1967).

LOVE

J. D. Love and L. Houver, A Summary of the Geology of Sedlennegry Bas lus of the Unlted Staces. Wlth Reference to the DIspusal of Ridiudict ive Westen, U.S. Ceological Survey Trace Elements linv. Repori 768 (upen filu) (1960).

LYNCH

E. J. Lynch, Foreat Ion Evaluat Lun, Harper and Row, Niew Yurk, N.Y., (1962).

\section{LnN 1962}

8. D. Lynn and 2. E. Arltn, "Deep Well cunetrucetion for the Dlsponal of Uraniua Mill Talling Hater by the Anacunda Co. at Crants. N. M.." Trans. A.s. Inst. MAn. Eng. 223(3), 230 (1962).

\section{LVNN $1962 A$}

R. D. Lynn and 2. E. Arlin, "Anaconda Succesefully Dlaposers of Uranta Mill Weate Water", Deep Wall InjectIon," Min. Eng. $14(7), 49$ (1962).

\section{MCLACMLAN}

M. E. Maclachlen, The Anedarko Bae In (uf perte of Oklahuma, Toxag, Kanwus. and Colorado), U.S. Goological Survey Trace Elemene Inv. Repore 831 (1966).

\section{MTTHENS}

C. 5. Mathowe and D. C. Ruenell. Praseure Bulldup and Fly Iugete In Holly. A. Inet. of Minine. Met., and Petr. Engra., Soc. of Potruleur Engrs. Monosraph Vol. 1 (1967).

\section{$\operatorname{mecans}$}

T. P. Mccenn at al., "Poselbilities for Disposal of Induetrial Wastes in Subsurtace Rock of North Plank of Appelachian Bas In In New York." In

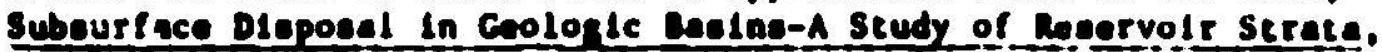
A.A.P.C. Kasolr 10, A. Aneoc. Petroteun Goologiste, Inc., Tules, okls. (1968).

\section{Moctain}

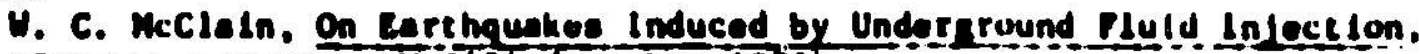

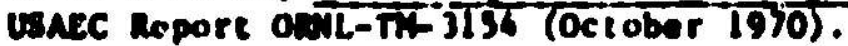


Mikilit.

1. E. Mokec and H. W. Woite, Water Muallty Crlterld, Californid State Waler Quallty control Board Publleation id. 3-A (1963).

MCMILI.IOS

L. C. McMlllion and D. Olsson, "Regulatury and Legal Aspects of Aquifer Management," in Watcer-1972, Vol. 69, G. F. Bennelt, ed., AlCHE Symposium series. No. 124, Americill Instleute of Chemical Engineers, New York, p. $345(1971)$.

MODE.:

D. D. Muden $\because:$ : "Lahoralory System for Trit lum Analysis of Large Numbers of Evvlrunmental Samples," In frlt lum, A. A. Mughissi and M. W. Carter, eds., Messenger Graphles, Publishers, Phoenix, Ardz. and Las Vegas, Nev., p. 512 (1973).

MISHELEY

J. C. Muscley and J. F. Malína, Relationshlps Between Selected Physical Parameters and Cust Responses for the Decp-Well Disposal of Aqueous Industrial Wistes, liniversity of Texas Center for Research in Water Resinutcen CRivi Pub. 28, dustin. Texas (1968).

\section{MURBACH}

E. H. Murbach $:$ : 2 , Flssion Product Gas Retention Process and Equipment Design study, USAFC Report ORNL-TM-4560 (May 1974).

NAS-NRC 1957

Nat Ional diademv of Sciences-Nat lonal Research Counc1l, Compltee on Waste Disposil of the Divis ion of Earth Sciences, The Dlsposal of Radioactive Waste on Land, Silt lonal Academy of Sclences-National Research Council Publicietion Sly (Sepleaber 1957).

NAS-NRC- 1572

Nat Ional Acidems of Sclences-Nat Ional Resuarch Council, Comittee on Radlact Ive Waste Management, An Evaluation of he Concept of Storing Radlasct Ive Hasteg in Bedrock Below the Savannah River Plant Site. National Acadewy of Sclences, Washington, D.C. (1972).

NivTON

V. C. Newton, Jr., Geologic Consideration In the Disposal of Chemlcal and Radloactive Waster, Oregon Dept. of Geolongy and MInerul Industries, Portland, Oregon (1970).

NEDO- 14504

General Electric Cu., San Jose, Callf. , Nuclear Energy DIv., Midweet Fucl Recovery Plant. Prelielnary Safety Analyeis Report, Neendent 14 (Includes AppIIcant'Environcental Report), also lleted as DoCkET-50268-11 (July IकाT).

NEDO-14504-2

General Electric Cn., San Juee, Callf.. Nuclear Energy Div., Applicant's Environeental Report, Suppleaent 1, Midwest Puel Rocovary Plant, Morris, IIIInole (November 1971). 
NFS

Nuclear Fuel. Services, Inc., West Valley, N. Y., West Valley Reprocessing Plant. Environmental Report, DOCKET-50-201-14\% (Deicumer 1973).

NORTH

E. D. North and R. L. Booth, Fission Product Gas Retention Study Final

Report, USAEC Report ORNL-TM- 4409 (August 1973).

NUCIEONICS WEEK

"Appeals Court Says EPA Must Regulate Radloactive Effluents," Nuclaunics

Week 15(51), 1 (1974).

JRNL

Oak Ridge Nat Loral Laboratory, Siting of Fuei Reprocess Ing Plants and

Waste Management Fac1litir:

ORSANCO

Ohio River Valley Water Sanitation Commission. Underground Injection of

Wastewater in the Ohlo Valley Region, ORSANCO, Cinclimat $i$, Ohin (19i3).

OTT INGER

R. S. Ottinger et ai., Recommended Methods of Reduction, Neutrallzation, Recovery or Disposal of Hazardous Waste Vol. III. Disposal Process

Descrlptions-Ultimate Disposal, Incineration, and Pyrolys 18 Processes, EPA-670/7-73-053-c (August 1973).

\section{PIMENOV}

M. K. Pimenov, "Studies and Technology of the Subsurface Dispusal of Liquid Radioactive Wastes," translation of Pp. 23-30 frum Proceedings of Science-Technical Conference held in Kolubzheg, Poland, October 2-7, 1972 , Vol. 2, ORNL-tr-28v2.

PIPER

A. M. Piper, "Disposal of Liquid Wastes by Infection Underground: Neltler Myth nor Millentum," in Water-1969, L. K. Cecil, ed., Cliem. Eng. Progr. Symp. Ser. No. 97, Vol. 65, p. 5, American Instltute of Chemical Englneers, New York, N.Y. (1969).

\section{PIRSON}

S. J. PIrson, Handbook of Hell Log Analys Is, Prentice-Hall, linc., Englewood Cl1ffs, N.J. (1973).

RALEICH

C. B. Raleigh, "Earthquakes and Fluid Injection," la Underground Waste Management and Envi ronmental Implications, T. D. Cook, ed., A.A.P.G. Memolr 18, Am. Assoc. Petruleum Geologists, Inc., Tulsa, Okla., p. 273 (1972).

\section{REPENNING}

C. A. Repenning, Geologic Sumary of the Central Valley of California, with Reference to Diaposal uf Liquid Radionct Ive Wuste, U.S. Geologl cal Survey Trace Elements Inv. Report 769 (open f1le) (1961). 
RHINFHAMME:K

l. B. Rhine aamer and P. H. Lamberger, Tritium Control Technoingy, USAEC

Report WASH-1269 (December 1973).

RIENIKAR

S. V. Ribnikar and I. D. Pupezin, "Possibilitles of Tritium Removal from

Waste Waters of Pressurized Water Reactors and Fuel Reprocessing Plants,"

Proceedings of thi Thirteenth AEC Alr Cleanlng Conference, San Francisco, Callfornta, Augi:: 12-15, 1974, M. W. Flrst, ed., CONF-740807, Vol. 2 , p. 929 (Mirch i 975 ).

RUBBERTSON 1973

3. B. Ruburtson and J. T. Barraclough, "Radioactive- and Chemical-Waste Trinsport in Groundwater at National Reactor Testing Station, Idaho: 20-Year Case Hlstury and Digital Model," in Underground Waste Management and Artificial Kecharge, Vol. 1, J. Hraunstein, d., Am. Assoc. Petroleum Geologists, Inc., Tulsa, Okla., p. 291 (1973).

ROBERTSON 1974

J. B. Rubertson it $i$., The Influence of Liquid Waste Disposal on the Geochemistry of Water at the National Reactor Testing Station, Idalio: 1952-1970, U.S. Geological Survey, prepared In Cooperation with the U.S. Aromic Energy Comission, IDO-22053 (February 1974).

ROE:DDER

E. Roedder, Problems in the Disposal of Acid-Aluminum N1:rate High-Level Radioact Ive Waste Sulutions by Injection Into Deep-Ly Ing Permeable Format lons, U.S. Geoluglcal Survey Bulletin 1088 (1959).

R(II)D

N. Rudd, Subsuriace liquid Waste Dlsposal and 1 ts Feaslifility in Pennsylvania, Penns:-lvania Geologlcal Survey, Fourth Serles, Environmental Geology

Report 3, Harrisburg. Pa. (1972).

\section{SANDBERG}

C. A. Sandber , Geology of the W11118ton Bas In, North Dakota, Montana, and South Dakota, with Reference to Subsurf ace Dlsposal of Radioactive Wastes. U.S. Geological Survey Report TEI-809 (1962).

SBAR

M. L. Sbar and M. L. Sykes, Contemporary Conpressive Stress and Selsalcity In Eastern North Amurlca: An Example of Intraplate TectonlcB, Ceol. Soc. Am. Bull. 84(6), 1861 (1973).

\section{SCILUMBERGER}

Schlumberger, Schlumerger Englneered Product ion Services, Schlumberger, Houstion. Texas (1970).

SELM

R. P. Sela and B. T. Hulse, "Deep-Woll Disposal of Induetrial Hastes," In 14th Indus. Waste Conf. Proc.: Purdue Universicy Ens. Exc. Ser. No. 104. P. 566 (1959). 
SPITSYN 1971

V. I. Spltsyn et di., "Sclentlfle Basing and Practive ol l.Iquid Radiontive Wastes Disposal in Deep Cieological Strata," A/Cunf. 49/1/426, presented at the Fourth Untted Nat fons lnternat lona! contcronce on the l'ediceful Uses of Atomic Energy, Geneva, Swltzerland, September $6-16,1971$, procecedings 11. 369 (1972).

SPITSYN 1972

V. I. Spitsyn and V. D. Balukova, "A Study of the Interaction of Wastess with the Geological Material Subsurface Deposituries and Development "it Methods of Preparation of Wastes for Disposal," Cransiat ion of pp. 7-10, from Proceedings of Sclence-Technical conference he Id In kolobzhug, poland. October 2-7, 1972, Vol. 2, ORNI,-tr-2789.

\section{STEVENSON}

C. E. Stevensort, "Solvent Extraction Processes for tinriched Urantium," In Sympostum on the Reprocessing of I rradiated Fuels Hold at Brussels, Belg1um, May 20-25, 1957, Book I, USAFC Repori TiD-7534, 1). 152 (1957).

STRAUB

C. P. Straub, Low-Level Radioact ive Wastes, Their Handling. Treatment and Disposal, U.S. Atomic Energy Commission, Divislon of Technical Information (1964)

SUN

R. J. Sun, "Hydraulic Fracturing as a Toul for Disposill ot Wastes in Shale," In Underground Wasce Management and Artiflclal Rech.urge, J. Braunstein, ed., Am. Assoc. Petroleum Geologists, Inc., Tulsa, (1kla., p. 219 (1971).

SWARTZ

J. H. Swartz, "Resigeivity Studles of Some Saltwater Buondaries in the Hawalian Islands," Trans. Am. Geophys. Unlun 18, 387 (1937).

TALBOT

J. S. Talbot. "Requitements for Monitoring of Industrill Decp Well Disposal Systems," In Underground Waste Management and Envi ronmen! al Impl icat luns, T. D. Cook, ed., A.A.P.G. Memoir 18, Am. Assoc. Petruleum Geolugists, Inc., Tulsa, Okla., p. 85 (1972).

THOMPSON

h. Thoupson, U.S. Environental Protectlon Agency, personal communfiation (July 1975).

\section{TREVORROW}

L. E. Trevorrow, "Storage and Disposal of Tritlum," In Chemical Engincering Divinion Wege Mangeement Programs Quarterly Repert Apr 11-Junu 1974. USAEC Report ANL-8134, p. 23 (1974).

TUCKER

H. E. Tucker and R. E. KIdd, Deep Hell Disposal In Alubama, Al abano

Ceological Survey Bulletin 104, Universily, Alabian (1973). 
USil)

L.S. Department if the Interior, Water Qualicy Criteria, U.S. Dept. of Intertur, Federal Witer pollution Control Administration (j968).

USEPA $1973 A$

V.S. Environmental Protection Agency, linvironmental Analysis of the Uranium Fuel Cycle. Part 111-Nuclear Fuel Ruprocessing, EPA-520/9-73-00 j-D (octobir 1973).

USEPA $1973 \mathrm{~B}$

U.S. Envirunmental Protect I on Agency, At lanta, Ga. Region IV, Ocean Out falls and Other Methods of Treated Waste Water Disposal in Southeast Flurida. Transcript of Pruceedings. Held In Lake Worth, Florida, January 24,1973 , Mlam Beach, Florida, January 26, 1973 , Fort Lauderdale, Flortdd, January 27,1973 , U.S. Environmental p. rection Agency, EIS-FT.73-0491-F-1 (March 1973).

USEPA 19;3C:

U.S. Environmental Protection Agency, At lanta, Ga. Region IV, Ocean Out falls and Other Methods of Treated Waste Water Dispusal in Southeast Flurida. lranscript of Proceedings. Held in Lake Worth, Florida, January 24,1973 , Miami Beach, Florida, January 26, 1973 , Fort Lauderdale. Flurida, Jinuary 27,1973 , U.S. Environmental Protection Agency, Els-Fl.$73-0491-F-2$ (March 1973).

('STIPA 1973D

U.S. Envirommental Protectlon Agency, Atlanta, Ga. Region IV, North Dade County Regional Collection, Treatment and Disposal System. U.S. Environmental Protection Agency, EIS-FL-73-1600-F/GA (October 1973).

USEPA 1974

U.S. Invironmental Protection Agency, Compllation of Industrial and Municlpal Inject Ion Wells in the United States, 2 Vols., EPA-520/9-74-020, U.S. Environmentil Protection Agency, Washington, D.C. (1974).

USIIPA 1975

U.S. Environmental Protection Agency, "Interim Primary Drinking Water Regulat lons," Federal Register, 40(158), 34324 (1975).

USPHS 1946

U.S. Public Hellth Service, Drinking Water Standards. Public Health Rep. $61(11), 371(1946)$.

ISPllis 1962

U.S. Public Health Service, Public Health Service Drinking Water Standards. t..S. Public Healch Service Pub. No. 956 (1962).

WARNER 1965

D. L. Warner, "Deep-Well Injection of Liquld Waste," U.S. Publlc Heilth service Envirunmental Health Serlea, Pub. No. 999-WP-21 (1965). 
WARNER 1966

D. L. Warner, "Decp-Well Waste lajectson - Reaction wilh Ayuiter Wilcer,"

Proc. Aar. Soc. Cive king. 92(SA4), $45(1960)$.

WARNER 1967

D. L. Warner, Deep Wells for Industrlal Waste lnjeylton in the Uniled States, summary of Data, Federal Water Pollution chilitul Administratiul, Water Pollution Control Research Series Pub. WP-20-10 (1907).

WARNER 1968

D. L. Warner, "Subsurface Disposal of Liquid Indust rial Wistes by DecpWell Infection," in Subsurface Disprisal in Geologlc Basins - A SLIdy of Reserveir Strata, J. E. Galley, ed., A.A.P.G. Memolr 10, Am. Assoc.

Petroleum Geologists, Inc., Tulsa, Okla., p. $11(1968)$.

WARNER 1969

D. L. Warner, "Preliminary Field Studles Using fiartl Resistivilv Measurements for Delineating Zones of Contuminated Ground Water." Ground Water ?(1), 9 (1969).

\section{WARNER 1972}

D. L. Warner, Survey of Industrial Waste In Jectlon Wells, final repurt, United States Geological Survey Contract No. 14-008-0001-12280, Univerifly of Mlssouri, Rolla, Mo., 3 vols. (1972).

WASH 1174-74

Office of Industry Relat Ions. The Nuclear Indust ry 1974, WASH-1174-74, U.S. Govt. Printiog off 1 ee, Washington, D.C.

\section{WEAST}

R. C. Weast, ed., Handbook of PhyslcB and Chemistry, 5lst Edltion, The. Chemlcal Rubber Co., Cleveland, Ohio, 1970-1971.

WEST

S. W. West, Disposal of Uranium-Mill Effluent by W. 11 Infection in the Grants Area, Valencla County, New Mexlco, U.S. Geologlcal Survey

Professional Paper 386-D (1972).

\section{WILSON}

H. E. WIlson et al., "Hydrologlc Evaluation of Industrlial-Hante Injection at Mulberry, Florida," In Underground Waste Management and Art 1f lidia! Recharge, J. Braunstein, ed., Am. Assoc. Petruleum Geologists, Inc.. Tulsa, Okla., p. 552 (1973).

\section{WITHERSPOON 1967}

P. A. Witherspoon et al., "Interpretation of Aquifer Gas Storage Conditlons from Water Pumping Tests," Am. Gas Assoc., Inc., New York, N.Y. (1967).

\section{WITHERSPOON 1972}

P. A. Witherspoon and S. P. Neuman, "Hydrodynamlcy of Fluid Injection." In Underground Haste Management and Envl roneental laplicat Long, T. D. Cook, ed., A.A.P.G. Henolr 18, A. Assoc. Petroleu Geologista, Inc., Tulsu. Okla. (1972) 
Y(i)IN

F. P. Yudin, "Hedt Factor in the Problem of the Underground Disposial of l.iquid Kadioactlve Wastes," translation of pp. 36-45 from Proceedings of sclence-Technical conference held in Kolobzheg. Poland, october 2-7, 1972 , Vul. 2, ORNI-tr-286i.

ZEMANEK

J. Zemanek ? $\therefore$, "Formation Evaluation by Inspection with the Borehole Televiewer," (icophusics 35(2), 254 (1970). 
